\author{
SZEGEDI TUDOMÁNYEGYETEM \\ BÖLCSÉSZET- ÉS TÁRSADALOMTUDOMÁNYI KAR \\ NEVELÉSTUDOMÁNYI DOKTORI ISKOLA
}

EGÉSZSÉGNEVELÉS DOKTORI PROGRAM

BERKI TAMÁS LÁSZLÓ

\title{
A SPORT-ELKÖTELEZŐDÉS MODELL ÖSSZEFÜGGÉSEINEK VIZSGÁLATA SERDÜLŐ SPORTOLÓK KÖRÉBEN
}

PhD értekezés

Témavezető:

Prof. Dr. Pikó Bettina, D.Sc.

egyetemi tanár

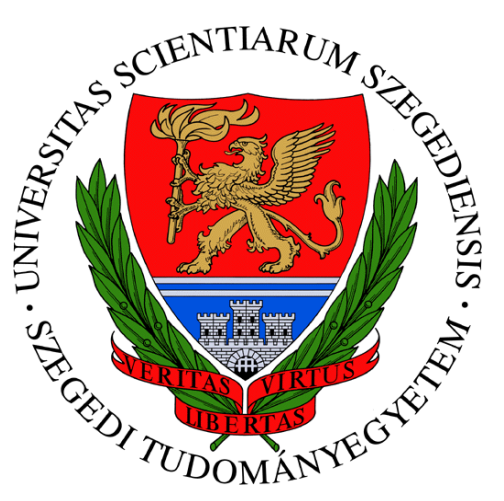

Szeged, 2020 


\section{TARTALOMJEGYZÉK}

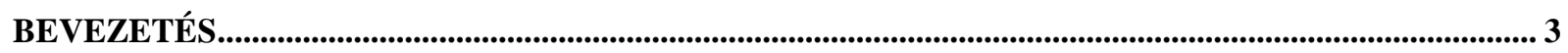

1. ÉLETMÓD, EGÉSZSÉG, EGÉSZSÉGMAGATARTÁS.................................................................... 6

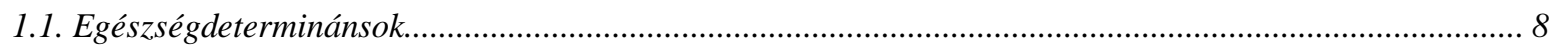

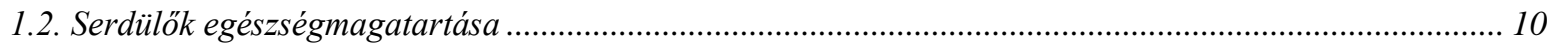

1.3. A serdülök egészségkockázati magatartása ...................................................................................... 11

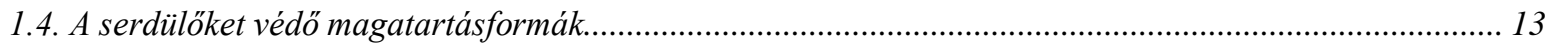

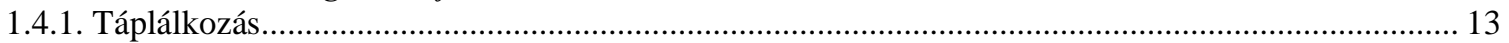

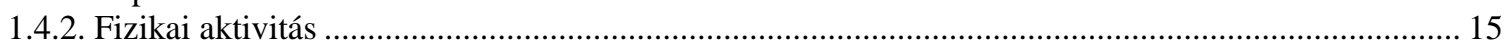

1.5. A fizikai aktivitás egészségre gyakorolt hatásai.............................................................................. 16

2. A SPORTOLÁST BEFOLYÁSOLÓ PSZICHOLÓGIAI TÉNYEZŐK..................................................... 19

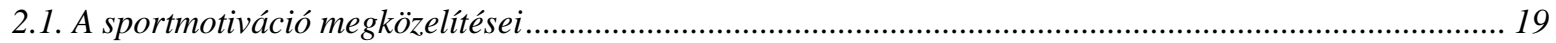

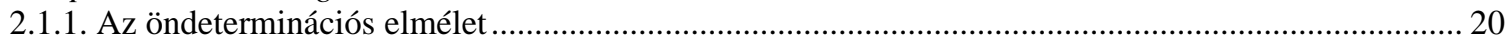

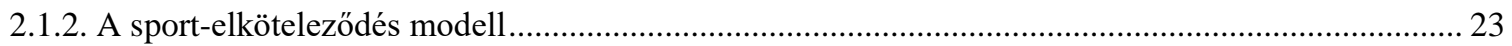

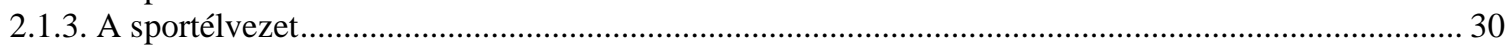

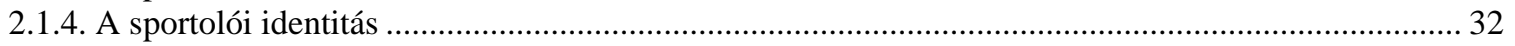

2.2. A perfekcionizmus megközelitései és jelentösége a sportnevelésben ………........................................... 34

2.3. Az egészségpszichológiai elméletek összefüggései és jelentösége az egészségnevelésben ......................... 37

3. AZ EMPIRIKUS KUTATÁS RELEVANCIÁJA, CÉLJA ÉS HIPOTÉZISEI.......................................... 40

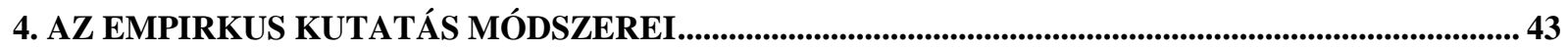

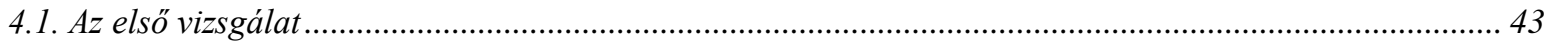

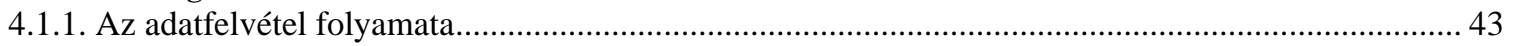

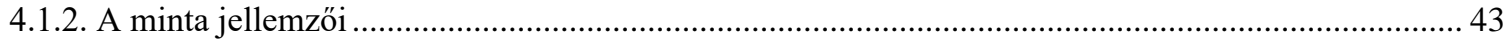

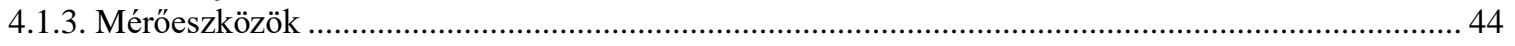

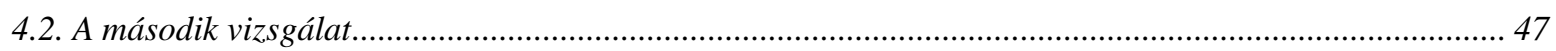

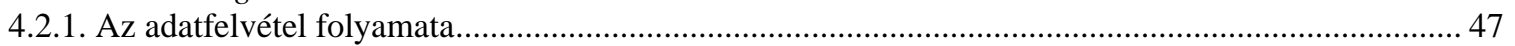

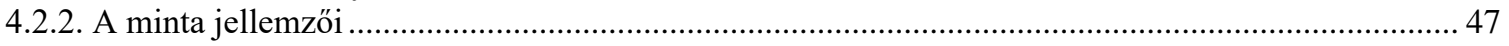

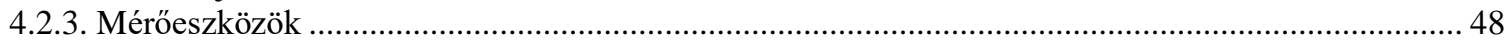

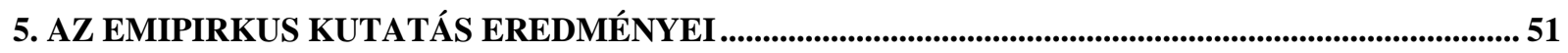

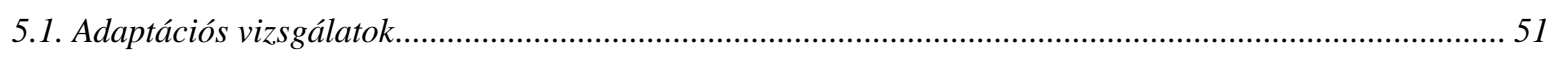

5.1.1. A sport-elköteleződés kérdőív-2 adaptációs vizsgálata...................................................................... 52

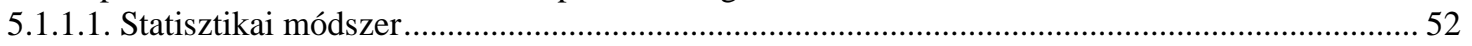

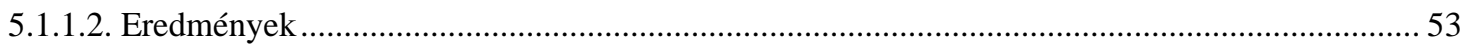

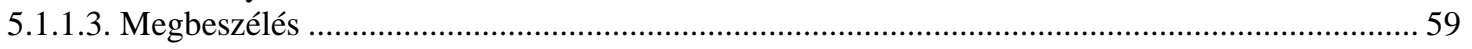

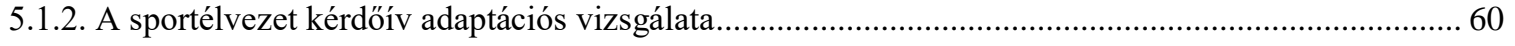

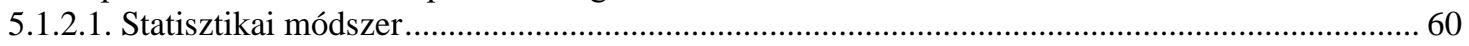

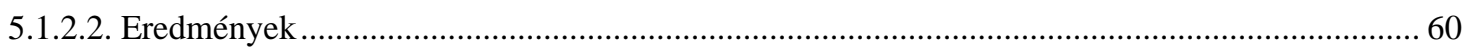

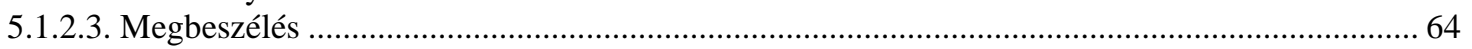

5.1.3. A magyar változatú sportolói identitás skála adaptációs vizsgálata................................................... 65

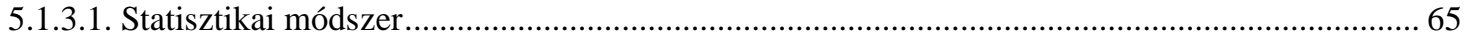

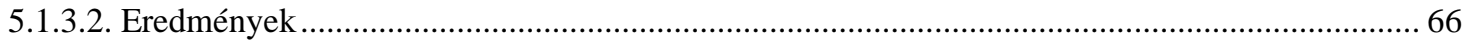

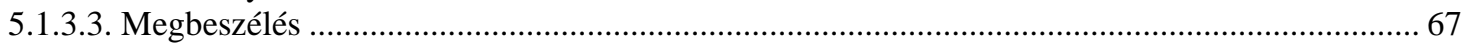

5.2. Sportolási szokások és a szociodemográfia szerepe a sport-elköteleződés modellben................................ 68 
5.2.1. A sport iránti elköteleződés összefüggése a sportolási szokásokkal és demográfiai tényezőkkel...... 68

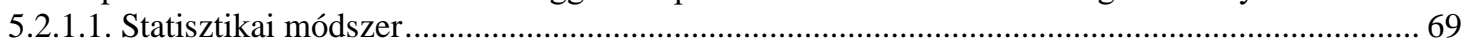

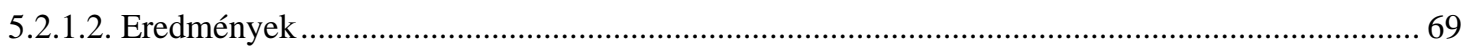

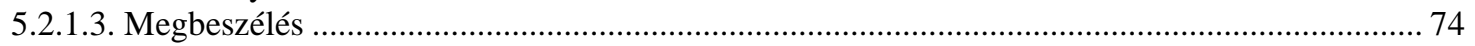

5.2.2. A sport iránti elköteleződés összehasonlítása a különböző sportágak képviselöi között....................... 76

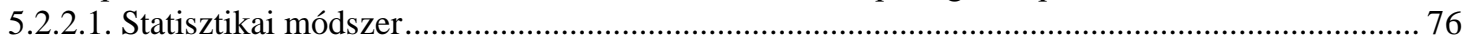

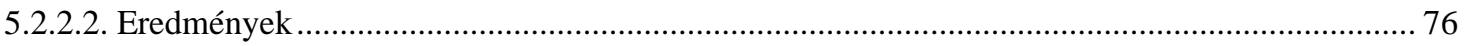

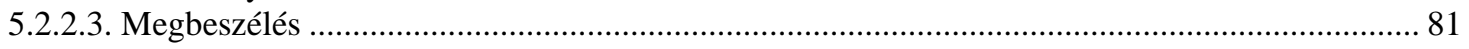

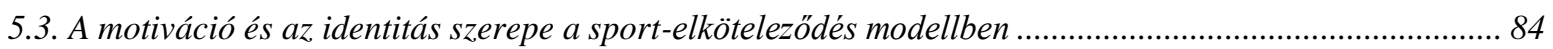

5.3.1. A sport-elkötelezödés modell és az öndeterminációs elmélet kapcsolata ........................................... 84

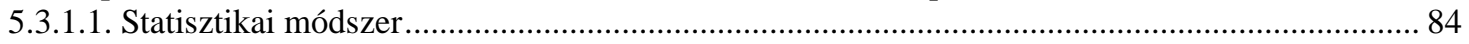

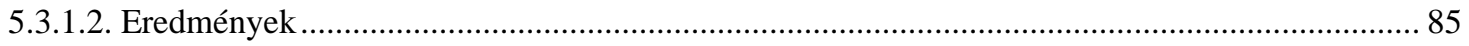

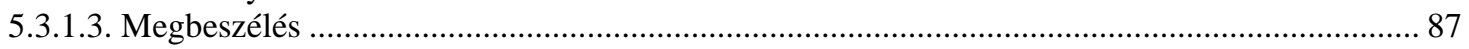

5.3.2. A sportolói identitás összefüggései a sport iránti elköteleződéssel.................................................... 90

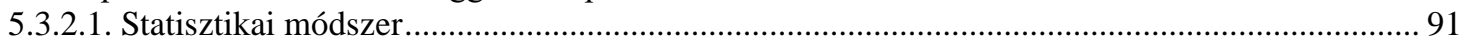

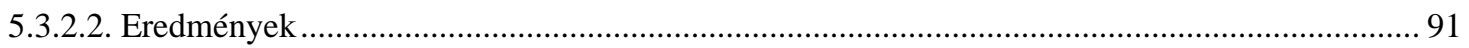

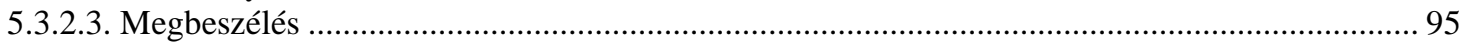

5.4. Az egészségpszichológia szerpe a sport-elkötelezödés modellben ............................................................ 98

5.4.1. A sport-elköteleződés modell összefüggései................................................................................. 98

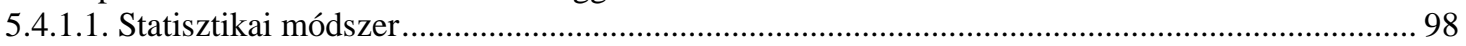

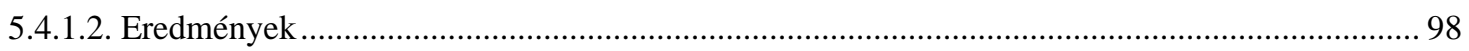

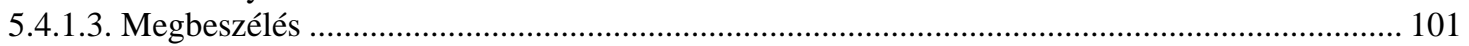

5.4.2. A sport-elköteleződés modell kapcsolata az egészségpszichológiával .............................................. 103

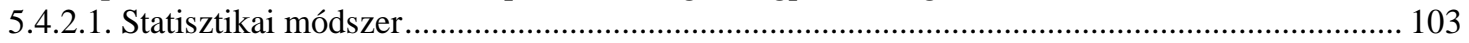

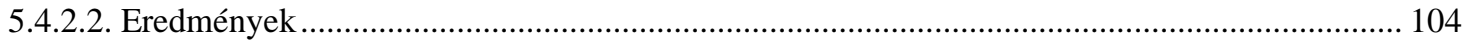

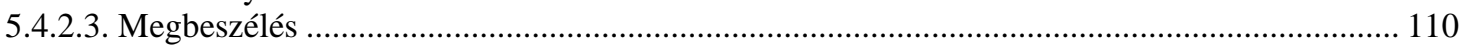

5.4.3. A tökéletességre törekvés és a sport-elkötelezödés kapcsolata......................................................... 113

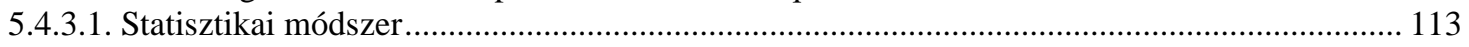

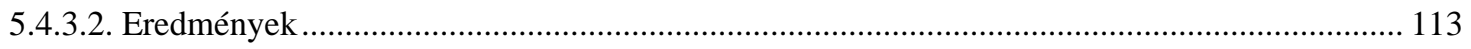

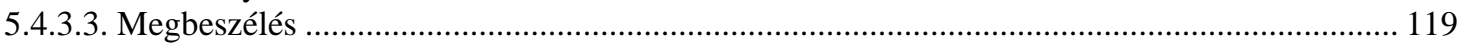

5.5. A sportélvezet vizsgálata ............................................................................................................ 122

5.5.1. A sportélvezet jelentősége és pszichológiai hátterének vizsgálata serdülő sportolók körében.......... 122

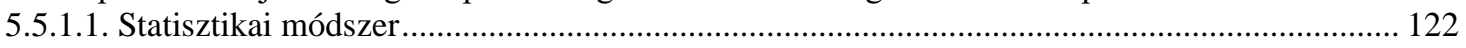

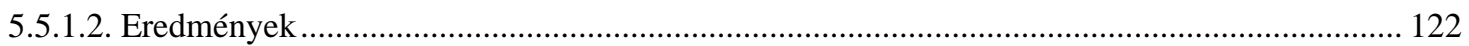

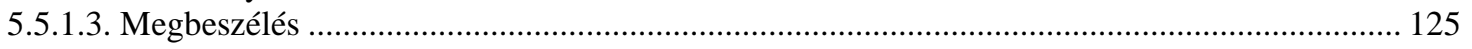

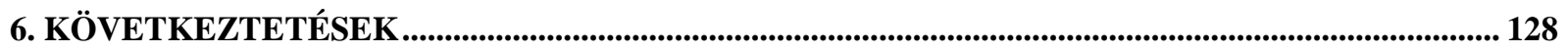

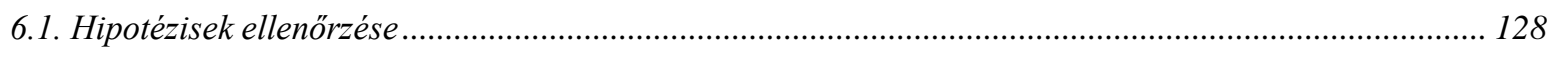

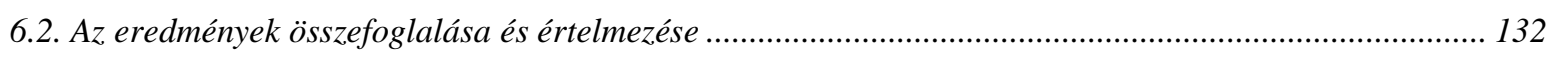

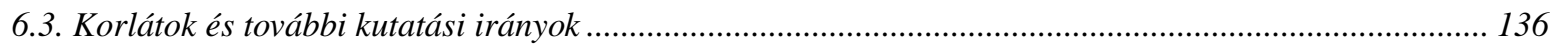

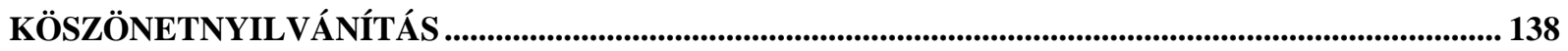

IRODALOMJEGYZÉK..................................................................................................................... 139

ÁBRÁK JEGYZÉKE ............................................................................................................................... 160

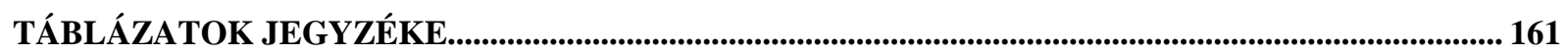

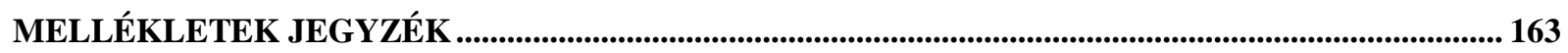

A JELÖLT DISSZERTÁCIÓHOZ KAPCSOLÓDó PUBLIKÁCIÓI ................................................................ 177 


\section{BEVEZETÉS}

Játék, kihívás, sport a testmozgás legfőbb ismérvei. Számtalan gyerek és felnőtt sportol az egészségéért, a barátaiért, a szórakozásért, vagy csak azért, hogy legyőzze saját magát. Örömteli tény, hogy az ország állampolgárainak sportolási kedve napjainkra rohamosan megugrott, melynek köszönhetően lépten-nyomon, épülnek a szabadtéri kondi parkok és létesülnek a mindenki számára ingyenesen használható futópályák. Ács és Kovács (2015) adatai szerint az elmúlt években a magyar társadalom inaktív rétege kilenc százalékkal csökkent, ami kiemelkedő eredménynek számít, ismerve a történelmi viszonyainkat. Ezek igen örömteli adatok, hiszen a rendszeres testmozgás nélkülözhetetlen a megfelelő testi és szellemi egészség állapotához.

Kutatások százai bizonyítják, hogy a rendszeres fizikai aktivitás számos pozitív hatással bír a testi és a szellemi egészségre egyaránt. A sport fontos preventív szerepet tölthet be a különböző szív- és érrendszeri megbetegedések (pl.: Gero és mtsai, 2018), a túlsúly vagy a csontritkulás megelőzése terén (pl.: Beck, Daly, Singh és Taaffe, 2017). Kutatók azt is megállapították, hogy a fizikailag aktívabbak magasabb önértékeléssel rendelkeznek, magabiztosabbak (Mistretta és mtsai, 2017), jobban tanulnak (Van Dusen és mtsai, 2011), magasabb az érzelmi intelligenciájuk (Gáspár, Soós és Szabó, 2017) és a depressziós tünetek is jobban elkerülik őket, mint a kevesebbé aktívakat (Wiles és mtsai, 2012).

Napjaink vezető betegségei az ún. krónikus, nem fertőző betegeségek, amelyek az egyén inaktivitásával és olyan életmódbeli rossz szokásokkal hozhatók összefüggésbe, mint a túlzott táplálékfogyasztás és különbözö egészségkockázati magatartásformák (pl.: dohányzás). A World Health Organization (WHO) adatai azt mutatják, hogy a világszinten történő évi 56 millió halálesetből 52 százalék vezethető vissza a helyes életmód hiányára (Meier és mtsai, 2018). Sajnos itthon is hasonló számokkal találkozhatunk. A Nemzeti Egészségfejlesztési Intézet adatai szerint a korai halálozásokért, azaz a 65 évnél fiatalabbak halálozásáért, elsősorban keringési és daganatos megbetegedések a felelősek (Vitrai és Varsányi, 2015), melyek egyértelmüen az egészséges életmód hiányára is vezethetők vissza. Ezek az adatok sokat javultak az elmúlt években, de még mindig elmaradnak az Európai Unió átlagától. Ugyanakkor fontos megjegyezni, hogy a Központi Statisztikai Hivatal (KSH) 2015-ös jelentése szerint a 15 évnél idősebb magyar lakosság egészségtudatossága jelentősen javult az elmúlt években (Vitrai és Varsányi, 2015). Ez a fejlődés igen örömteli, hiszen az egészségmegörzés 
egyik kulcsa, hogy az egyén tudatosan tegyen a saját egészségért. Érezhetően nő az ország sportolási kedve és javul az egészségmagatartása, de még így is jelentősen elmaradtunk a nyugati európai országokétól. Mint említettem (Ács és Kovács, 2015), csökken az inaktívak száma, de a 2018-as eurobarométeres felmérés adatai szerint a társadalom több mint fele még mindig nem végez semmilyen testmozgást.

A fizikai aktivitás egészségmegőrző szerepe miatt érdemes foglalkozni, azzal a kérdéssel, hogy miért is sportolunk. Miért érezzük fontosnak, hogy a sport az életünk részévé váljon. Számos motivációs elmélet is született már az elmúlt évtizedekben, amelyek igyekeznek feszegetni ezt a kérdést. A szakirodalom szerint azonban nem lehet egyértelmüen megválaszolni, mivel több tényező is szerepet játszhat a sportolás motivációjában. A kutatások szerint a társadalom motivációja igen széles skálán mozog, hiszen van, aki saját egészségért megy el egy 30 perces kocogásra és van, aki élete legjobb idejével akarja átúszni a Balatont (Ádám, Susánszky és Székely, 2018). Ezek a motivációs tényezők függhetnek életkortól, társadalmi státusztól és a környezettől is (Butt, Weinberg, Breckon és Claytor, 2011). Természetesen ezek mellett a barátoknak és a családnak is hatalmas szerepe van abban, hogy a sportos, egészséges szemlélet kialakuljon (Atkin, Johnson, Force és Petrie, 2015).

Véleményem szerint az egészségmagatartás pozitív hosszútávú fejlődését a fiatalok egészségtudatos nevelésével lehet elérni. Sajnos ök is ki vannak téve különböző káros szenvedélyeknek, a rohanó világunk adta stressznek és a helytelen magatartásformák kialakulásának. A serdülő korosztály még keresi a helyét a világban, így külön figyelmet érdemel, hiszen tanulmányok bizonyítják, hogy a serdülőkor szenzitív időszaka a legmegfelelőbb az egészségmagatartás és a sportolási szokások kialakítására (Trejos-Castillo és Vazsonyi, 2011). Ezért kutatásom fókuszában is a serdülők álltak, mivel sportolási szokásaik, sportmotivációjuk és egészségmagatartásuk megértésével javítani lehet egészségtudatosságukat, amely hozzásegítheti őket az egészséges és kiegyensúlyozott felnőtt korhoz.

A megfelelő egészségmagatartás kialakítását a köznevelés is fontos feladatának tekinti. A már meglévő és a készülő nemzeti alaptantervekben is számos utalás van a diákok test-lelki egészségre nevelésének, melyben helyet kap az egészséges táplálkozás tudatosítása, káros szenvedélyek visszaszorítása, szociális képességek fejlesztése és a sport (gondoljunk a mindennapos testnevelés bevezetésére). A közoktatás zárt rendszerén túl számos egyéb program 
célozza a serdülők egészségmagatartásának fejlesztését, melyek között a káros szenvedélyek prevencióján át, különböző fizikai aktivitást támogató kezdeményezések (pl.: Sportágválasztó) is megjelennek, hogy hosszútávon hozzájárulhassanak az egészséges nemzet kialakításához. Nem szabad elmenni amellett a tény mellett sem, hogy a sportnak az egészséges életmód megteremtése mellett, a nevelésben is óriási szerepe van. A sport fejleszti az önfegyelmet és a kitartást, segíti az önismeretet, a csapathoz való tartozás igényét és a szabálykövetést. A sport megtanít győzni és veszíteni, segíti a helyes önértékelést és fontos szerepet játszik a másokkal való bánásmód kialakításában is.

Ahogy láthatjuk, a rendszeres testmozgás kiemelt jelentőséggel bír az egészségért folytatott harcban, így dolgozatom középpontjában az egészségre nevelés, ezen belül is a serdülök rendszeres testedzése és sportolása, valamint az ezeket befolyásoló pszichológiai tényezők, elméleti modellek állnak. Ezért kutatásom fö céljának a sport iránti elköteleződés megismerését tekintem. Célom, hogy feltárjam, milyen tényezők befolyásolják a serdülőket a sportáguk iránti elköteleződésben, milyen összefüggések mutathatók ki az egészségmagatartás, sportolási szokások és a sport iránti elköteleződés között. A sport iránti vágy mélyebb megismerése pedig segítheti a kutatókat, pszichológusokat és a sport szakembereket a serdülők egészségmagatartásának javításában, mely hosszútávon hozzájárulhat egy egészséges jóléti társadalomhoz.

Értekezésemet három nagyobb részre osztottam. Az első részben kutatásom elméleti hátterét igyekszem bemutatni, melyben vázolom az egészség, egészségmagatartás fogalmait, annak determinánsait. Igyekszem körbejárni a serdülök egészségmagatartásának kérdéseit, valamint megvizsgálom kutatásom szempontjából a legrelevánsabb motivációs elméleteket, úgy, mint az öndeterminációs elmélet és a sport-elköteleződés modell. A második részben empirikus kutatásomat mutatom be. Megvizsgálom a sport iránti elköteleződés szociodemográfiai jellemzőit, annak kapcsolatát más motivációs elméletekkel és összefüggéseit különböző pszichológiai skálákkal. Az empirikus alfejezetek alapjait magyar és külföldi tudományos folyóiratokban megjelent publikációim adták. Disszertációm harmadik, terjedelmesebb részét a következtetéseimnek szentelem, ahol az eredményeket próbálom kontextusban helyezni. Kutatásomban igyekszem minél átfogóbb képet adni a serdülök sport iránti elköteleződéséről és az arra ható egészségpszichológiai változókról is. 


\section{1. ÉLETMÓD, EGÉSZSÉG, EGÉSZSÉGMAGATARTÁS}

Az ember életmódját mindennapi tevékenysége befolyásolja, amely igen széles skálára hat, többek között az egészségre is. Az emberiség történelmében mindig is központi szerepet játszott a betegségek elkerülése és a megfelelő életmód kialakítása. Már Arisztotelész korában is úgy gondolták, hogy az emberiség fejlődéséhez elengedhetetlen a fizikai és szellemi jóllét megléte (Bradly, Goetz és Viswanathan, 2018). A történelem kezdetének társadalmaira leginkább egyfajta holisztikus egészségfelfogás volt jellemző, mely az ember és környezete közötti egyensúly kialakítására törekedett. Ugyanakkor ez a fajta életfelfogás Pálmai (2017) szerint ma is reneszánszát éli.

Az egészség fogalmát nem könnyü definiálni. Létezik egy laikus hétköznapi elképzelés, miszerint az egészségnek egy negatív és egy pozitív megközelítése van. Az elöbbi leírja, hogy az egészség a betegség vagy a kóros állapot hiányát jelenti. Az utóbbi a jó erőnléttel, az élet élvezetével kapcsolható össze (Pálmai, 2017). Az egészség pontosabb meghatározásában a WHO elengedhetetlen szerepet játszott azzal, hogy 1946-ban alapító okiratában megalkotta az egészség fogalmát, mely a mai napig az egyik legismertebb egészségfogalom. Az 1946-ban megírt klasszikus definíció szerint „Az egészség nem csupán a betegség hiánya, hanem a testi, lelki, szociális jóllét állapota” (WHO, 1946; idézte Nagy és Barabás, 2011, 176. o.). A definíciót sokan támadják, hiszen nehezen alkalmazható a napjainkra jellemző folyamatosan változó környezetben (Pálmai, 2017). Ezen támadások hatására igyekeztek a definíciót az aktuális korra testreszabni. Így az 1986-os Ottawai Chartában az egészséget, mint értéket határozták meg. Bő tíz év múlva Dzsakartában a WHO frissítette a fogalmat, mely szocioökölógiai szemléletváltást hozott. E szerint: „,Az egészség nem valamiféle elvont állapot, hanem eszköz valamilyen végcél eléréséhez, amely a cselekvöképesség tekintetében úgy fogható meg, mint eröforrás, amely lehetővé teszi az. emberek számára, hogy egyénileg, társadalmilag és gazdaságilag is termékeny életet éljenek.” (Nagy és Barabás, 2011, 178. o.)

A szakirodalomban nem csak a WHO egészség megközelítéseiről írnak. A Borbás és munkatársai (2008) által megalkotott definíció ötvözi a biológiai szemléletet a mentális egészséggel, így fogalmukban mind a két megközelítésre kitér. Szerintük ,Az egészség az egyén biológiai müködése, valamint a kora és neme szerint elérhetö és/vagy a társadalom által elvárt biológiai müködése közötti megfelelés. Az egészség megítélése a funkciók 
müködésén (képességek, korlátozottságok), a fájdalom létén, jellegén, és mindennek az egyén általi mentális feldolgozásán (elfogadásán) alapul." (Borbás és mtsai, 2008) Az említett meghatározásokon kívül még számtalan definíció található a szakirodalomban. Nehéz igazságot tenni, hogy melyik foglalja össze a legjobban a fogalmat, de mindegyik meghatározása a jóllétre irányul.

Kutatásom szempontjából másik releváns fogalom az egészségmagatartás. Az egészségmagatartás olyan magatartásformákat jelöl, melyek segítenek a betegségek megelőzésében és a helyes életmód kialakításában. Matarazzo (1980) szerint az egészségmagatartáson belül megkülönböztetjük az egészségrizikó-magatartás (vagy kockázati magatartást, pl. szerfogyasztás, káros szenvedélyek, pl. dohányzás vagy alkoholés drogfogyasztás), illetve egészségvédő magatartást (pl. egészséges táplálkozás, sportolás), amelyek aránya életkoronként is változhat, pl. serdülőkorban gyakran az előbbi nő az utóbbi rovására (Fairclough és Stratton, 2005, Matarazzo, 1980). A helyes egészségmagatartás kialakítása leginkább az életmódon érhető tetten. Az életmód helyes kialakítása pedig alapvetően az egyénen múlik, amellett, hogy környezetünk is hatással lehet életmódunkra

A mai társadalomban megfigyelhető egyfajta paradoxon. Hiszen tudjuk, mit kellene tenni az egészségért és a helyes életmód kialakításáért, mégis a magyar társadalomban (a javulás ellenére) magas a cigarettázók száma, sok a rendszeresen alkoholt fogyasztó és kevés rendszeres fizikai aktivitást végző honfitársunk (Bárdor és Kraiciné, 2018). Sajnos leginkább akkor kezdenek el aggódni egészségükért az emberek, amikor már baj van, holott sokkal egyszerübb lenne az életmód következtében kialakuló (pl.: szív és érrendszeri) betegségek megelőzésére törekedni. Ezt a társadalmi problémát leginkább az egészséges életmódra nevelésen keresztül lehetne orvosolni. Számos program indult az oktatásban a helyes egészségmagatartás kialakítása érdekében (pl.: Egészségfejlesztési szakmai hálózat létrehozása címü TÁMOP projekt), mely az óvodától a felsőoktatásig igyekszik kialakítani a diákokban a helyes életmódot. A korosztályok közül a serdülő fiatalok a legveszélyeztetebbek, mivel itt jelenek meg elöször a különböző rizikó-magatartásformák (pl.: dohányzás) és kezd alábbhagyni a testmozgási kedv is. Ezért kiemelt jelentőséggel bír ez a korosztály az egészséges társadalomért folytatott harcban. 


\subsection{Egészségdeterminánsok}

Mielőtt részletezném a serdülő korosztály egészségmagatartását, fontos tisztáznunk, melyek azok a tényezők, melyek befolyásolhatják egy társadalom egészségi állapotát. Több nagyobb elmélet is foglalkozik e kérdéssel. Hídvégi és Bíró (2015) szerint az egészséget befolyásoló tényezőket két nagyobb csoportra lehet bontani (1. ábra). Az ábra szerint az egészséget külső és belső tényezők határozzák meg. A külsők elsősorban a környezeti (pl.: éghajlat, levegőminőség stb.) valamint a társadalmi hatásokat (pl.: életkörülmények, munkahely stb.) jelentik, míg a belső tényezők leginkább az egyéntől függenek (pl.: életmód, család, barátok stb.). Ide tartoznak továbbá az egyén számára befolyásolhatatlan genetikai azaz öröklött tulajdonságok is.

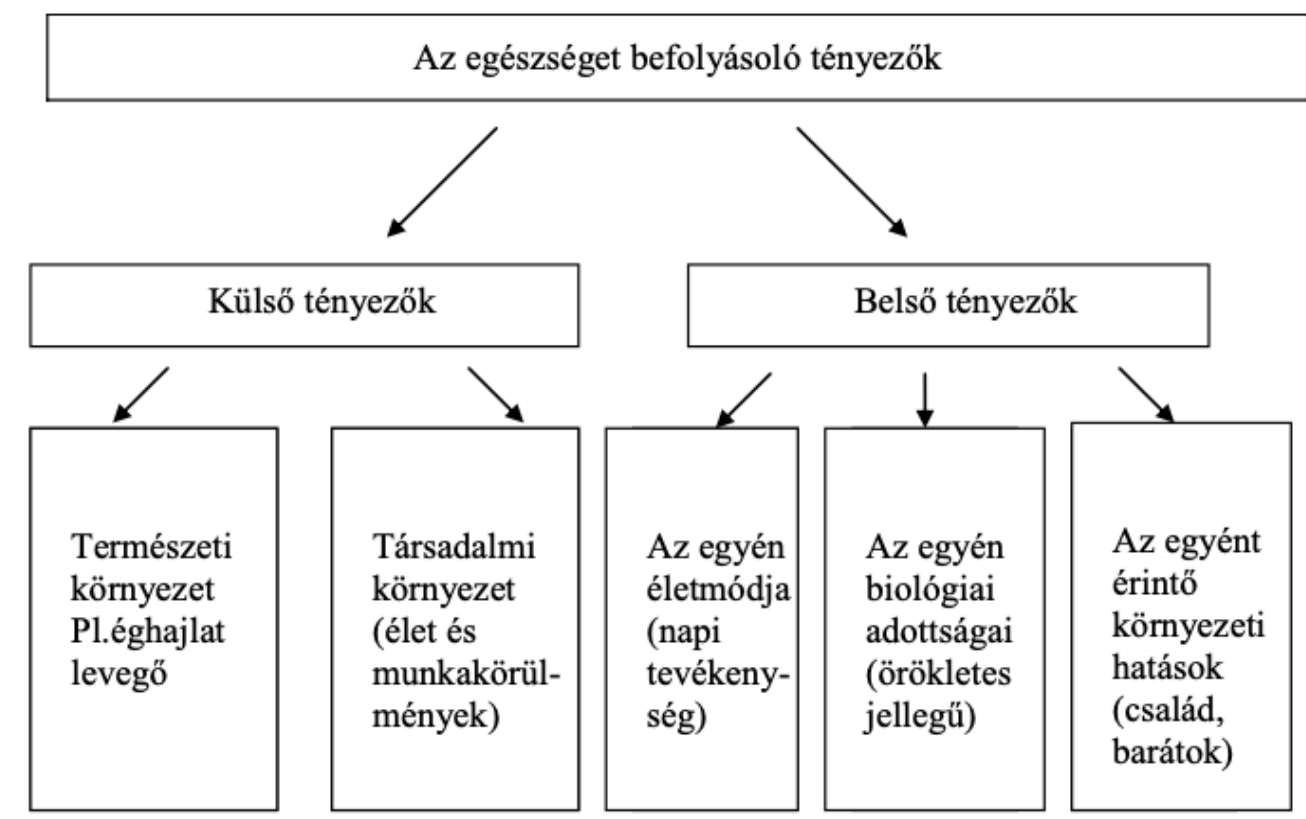

1. ábra. Egészséget befolyásoló tényezök (forrás: Hídvégi és Bíró,2015, 78. o.)

Az egészségdetermináns modellek közül érdemes megemlíteni, Dahlgren és Whitehead (1991) réteges modelljét is (2. ábra). A modell öt rétegben írja le az egyént befolyásoló tényezőket, mely kívülről a környezeti hatásoktól halad befelé az egyéni tényezők felé. A modell központjában a genetikai tényezők állnak, majd ahogy haladunk a környezeti tényezök felé megjelenik az életmód (benne az egészséges táplálkozással, rendszeres testmozgással), a társak szerepe, élet- és munkakörülmények, valamint az ezeket összefogó társadalmi hatások, és a fizikai környezet, melyek hatással vannak az egészségmagatartás kialakulására. 


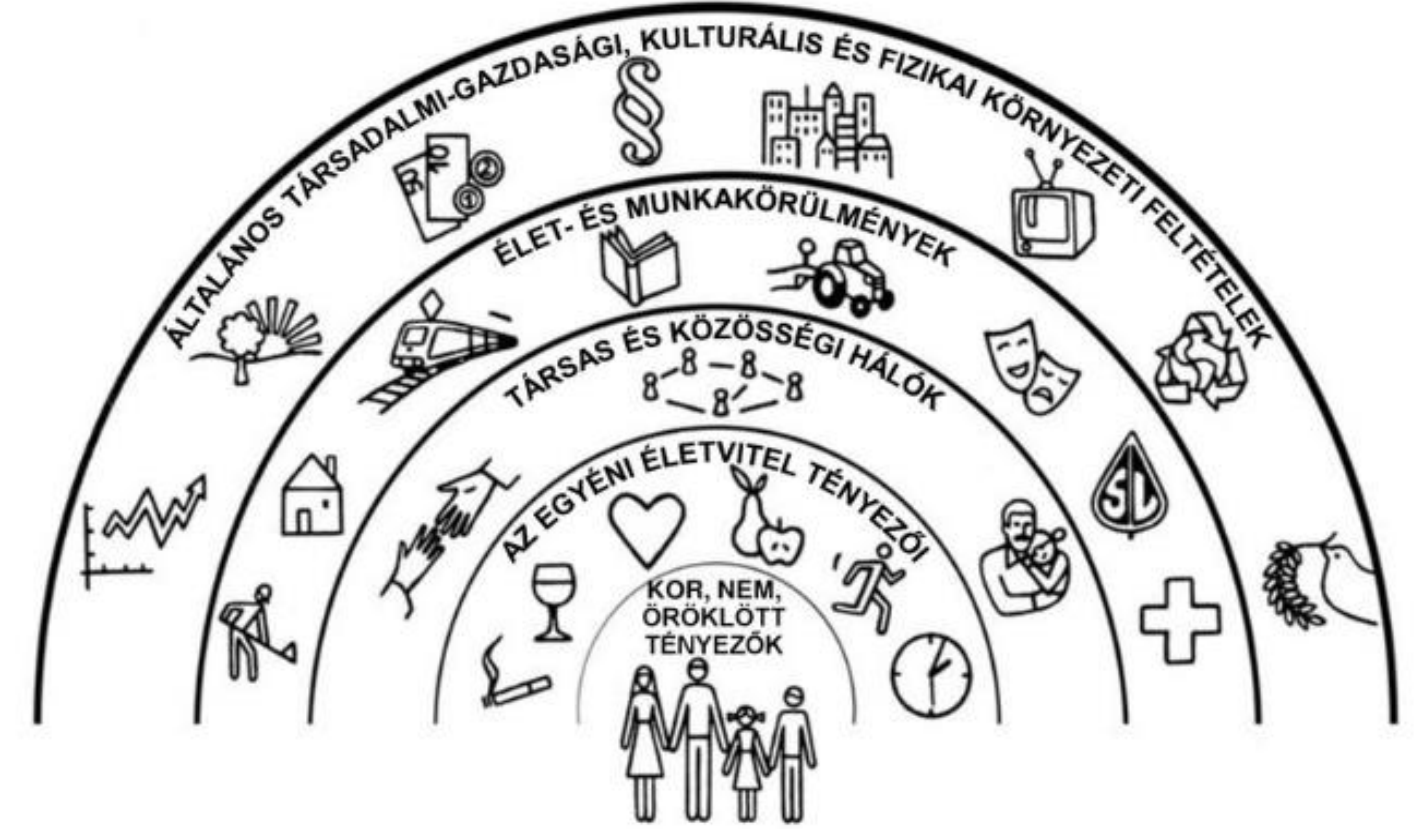

2. ábra. Dahlgren és Whitehead réteges modellje (forrás: Dahlgren és Whitehead, 1991

alapján, Orosz, 2001, 258. o.)

Érdemes megvizsgálni, hogy az előbb említett determinánsok milyen módon hatnak az egyénre. Marc Lalonde 1974-ben bemutatott egészség-mező elmélete szerint - melyet azóta is sokan használnak útmutatásként (pl.: Varga-Hatos és Karner, 2008) - az egészséget leginkább az életmód határozza meg (43\%). Ezt követi a genetikai tényező (27\%), a környezeti hatások (18\%) és legvégül az egészségügyi ellátás (11\%).

A különböző hatások vizsgálatával számtalan kutató foglalkozott már. A genetikai tényezők szerint a férfiak rizikómagatartásra való hajlama nagyobb (Osborne, Serdarevic, Crooke, Striley és Cottler, 2017), valamint kutatások azt is bebizonyították, hogy a társadalmi rang, munkahelyi státusz hatással vannak az egyének egészségi állapotára. Nemzetközi kutatások szerint így fordított arányosság áll fenn a halandóság és a munkahelyi ranglétrán elfoglalt pozíció között (Andersen és mtsai, 2020). A kutatók azt is kimutatták, hogy a jobb gazdasági-társadalmi helyzet hosszabb életet eredményezhet (Taylor és mtsai, 2015). A környezet és az egészség kapcsolatáról is számos publikáció látott már napvilágot (pl.: Légszennyezés és mortalitás, Szuhi, 2010). Az egyéni életvitel, mely dolgozatom szempontjából is a legrelevánsabb, és a kutatások szerint is közel 50 százalékban meghatározza az egyén egészségét, az a tényező, mely közvetlen hatással rendelkezik. életmódunkra. 
Mint az elméletekből látható, az egyéni életmódnak és egészségmagatartásnak kiemelt szerepe van az egészségmegőrzésében. Így ezek minél mélyebb és összetettebb megismerését elengedhetetlennek gondolom.

\subsection{Serdülők egészségmagatartása}

A fiatalok 12-14 éves korukban hatalmas változásokon mennek keresztül, melynek köszönhetően testi és szellemi fejlődésük rohamosan megugrik (Kiefer és Ryan, 2011). Serdülökorban jelennek meg a másodlagos nemi jellegek, ebben a korban indul be - különösen a fiúknál - a magasságnövekedés és ilyenkor kezdődik az egyén identitásának a kialakulása is, mely Erikson (1994) kutatásai szerint akár életük végéig is tarthat. A hirtelen változások sok pozitív és sok negatív hatást is magukban hordozhatnak. A kortársaiknak való megfelelés és az identitás keresése miatt a serdülők jobban ki vannak téve a különböző egészségkárosító magatartásformáknak, melyek megjelenésére is nagyobb esély van ekkor, mint a fiatalabb korosztályban. Sajnos ezek megjelenése akár hosszútávon is kihathat az egyén életmódjára. Például McKelvey és Halpern-Felsher (2017) szerint azok a serdülők, akik csak csupán heti 24 szál cigarettát fogyasztanak, nagyobb eséllyel válhatnak felnőtt korukra függő dohányzóvá. Igaz kutatásuk szerint ez az arány csekély, mindössze 5 százalék. Egy másik kutatás arra világított rá, hogy a dohányzást valaha kipróbáltak közül 20-25 százalék válik felnőtt korára függő dohányzóvá (WHO TPR, 2015). Hasonlóan fontos a fizikai aktivitás megszerettetése is a fiatal korosztály számára. Egy felmérés szerint a felnőtt korban rendszeresen sportolók 53 százaléka már gyermekkorában elkezdett sportolni (Neulinger, 2009). A látható hosszútávú hatás miatt ezt a korosztályt körültekintően kell kezelni. Az elmúlt években a problémát felismerve számtalan olyan prevenciós és kortárssegítő program indult az iskolákban és az iskolákon kívül is, melyeknek célja, hogy a fiatalok megismerjék a káros szenvedélyek veszélyeit, és tanácsokat kapjanak a helyes életmód kialakításához.

Sajnos a kutatások rámutattak arra a tényre, hogy akár egy egészségkockázati tényező is magával vonhat több másik kockázati tényezöt (Hodder és mtsai, 2018), valamint azt is felismerték a kutatók, hogy a káros egészségmagatartás formák megjelenésével, az ún. egészséget védő magatartásformák (pl.: sport, helyes táplálkozás) csökkennek. A felsorolt kutatásokból látható, hogy a minél szélesebb körủ egészségmagatartási formák kialakítása 
elengedhetetlen serdülőkorban, mert annál valószínübb, hogy az egyén felnőtt korban egészségesebben fog élni.

A serdülők és a fiatal felnőttek (15-29) egészségi állapotáról, egészségmagatartásáról és életmódjáról igen sok adat áll rendelkezésünkre a szakirodalomban. A téma fontossága miatt a hazai és a külföldi szakirodalom is számos aspektusból vizsgálja a gyerekeket és serdülőket egyaránt. Hazánkban a 2000-es évektől négyévenként készül egy átfogó tanulmány a magyarországi és kárpátmedencei fiatalok mindennapjairól, családi hátterükről és egészségmagatartásukról. Legutóbb 2016-ban a „Kutatópont” nevü kutatócsoport mérte fel e korosztály életmódját igen sok szempont alapján, melynek eredményét 2018-ban egy vaskos kötetben publikálták. Mivel egy négyévente elkészített keresztmetszeti tanulmányról van szó, ezért a pozitív és a negatív tendenciák egyaránt jól kimutathatóak. Természetesen több kutató csoport és nemzetközi szervezet is foglalkozik a rendszeres életmódfelméréssel. Magyarország több olyan nemzetközi felmérésben is részt vesz, mely a serdülők egészségmagatartását montírozza. Ilyen például az ESPAD (European School Survey Project on Alcohol and Drugs), HBSC (Health Behavour in School-Aged Children) kutatások vagy a 2003-tól rendszeres GYTS (Global Youth Tobacco Survey) felmérések.

A következőkben igyekszem azokat a számunkra releváns egészségmagatartási változásokat bemutatni, melyek jellemzőek a fiatalok elmúlt éveire és napjainkra, célom megvizsgálni a rájuk jellemző egészséget védő és az egészséget károsító faktorokat is.

\subsection{A serdülők egészségkockázati magatartása}

Kutatásomban nem térek ki a különböző rizikómagatartások vizsgálatára. A téma relevanciája miatt azonban fontos a serdülők rizikómagatartásainak megismerése, hiszen azok közvetett hatással vannak a fizikai aktivitás meglétére vagy hiányára (Lacorte és mtsai, 2016).

A felnőtt lakosságot is sújtó, és így serdülőket is a legjobban érintő legelterjedtebb egészségkockázati magatartásforma a dohányzás. A HBSC 2014-es felmérése szerint a magyar 15 éves serdülök 15 százaléka dohányzik rendszeresen, mely pontosan megegyezik a 2016-as HBSC felmérés adataival is. Úgy tünik, hogy a serdülők ebben a korosztályban kezdik el a rendszeres dohányzást, és ekkor kezd el meredeken emelkedni a dohányzók száma is. A kutatások szerint a 15 és 19 éves kor között emelkedik a legnagyobb mértékben a dohányzók köre (Ádám és mtsai, 2018). 19 éves korra a férfiak több mint 45, míg a nők csaknem 40 
százaléka dohányzik akár csak alkalomszerủen. A különböző módszertannal készült kutatásokat sajnos nehéz összehasonlítani. Ugyanakkor Ádám és munkatársai (2018) a magyar fiatalokat vizsgáló kutatásukban 2000-től áttekintve az adatokat arra jutottak, hogy 2016-ig 8 százalékkal emelkedett a dohányzók száma. Egy hasonló tanulmányban Balázs és Pikó (2016) dél-alföldi serdülőket vizsgált, és ők is hasonló számokat találtak. Felmérésükből kiderül, hogy a serdülők valamivel több, mint 16 százaléka dohányzik rendszeresen. A serdülöknél ez az arány eltérhet nemenként, iskolatípusonként, és változhat a családi állapot, valamint a társadalmi státusz függvényében is (pl.: szakgimnáziumok tanulói gyakrabban dohányoznak; Pénzes és Bíró, 2018).

Társadalmunkat szintén nagymértékben sújtó rizikómagatartás az alkoholfogyasztás. A 2016-os nagymintás ifjúságkutatás (Ádám és munkatársai, 2018) rávilágított arra a tényre, hogy a fiatalok alkoholfogyasztása folyamatosan változik. A kutatásban azt láthatjuk, hogy míg a naponta alkoholt fogyasztók száma csökken, addig az alkalmi alkoholt fogyasztóké 8 százalék pontot emelkedett a 2012-es felméréshez képest. Sajnos az alkoholt nem fogyasztók is egyre kevesebben vannak, ők a populáció 26 százalékát képviselik (ez a szám 2000-ben 41 százalék volt). 2014-ben a WHO által készített globális jelentés szerint is a magyar fiatalok vezető szerepet töltenek be a rendszeres alkoholfogy asztás terén. Ez a rangsor sajnos a teljes lakosságra kivetítve is hasonló képet mutat, hiszen az európai országok között Magyarország a legnagyobb „ivó”-k között van. Sajnos az alkohol kipróbálása egyre korábbra tehető a serdülők körében. Csizmadia és Várnai 2003-as felmérése szerint az első találkozás az alkohollal 11-13 éves korra tehető, és a kutatás szerint a fiatalok 51,3 százaléka már ebben a korban kipróbált, ez az arány pedig az életkor előrehaladtával folyamatosan nő (Csizmadia és Várnai, 2003). A különböző felmérésekből úgy látszik, hogy a korai kipróbálás mértéke egyre inkább emelkedik (Jernigan, Noel, Landon, Thornton és Lobstein, 2016).

Az alkoholfogyasztás és a dohányzás mellett a legjelentősebb rizikómagatartás a drogfogyasztás. A négyévenként készülő és legutóbb 2015-ben kiadott ESPAD (European School Survey Project on Alcohol and Other Drugs) jelentés szerint a megkérdezetett 9-10. évfolyamos diákok 19,5 százaléka próbált már ki valamilyen tiltott szert. Minden hatodik serdülő vett be gyógyszert orvosi javaslat nélkül és minden tizedik használt már valamilyen újonnan megjelenő dizájnerdrogot (Elekes, 2015). Úgy tủnik, hogy a fiúkra jobban jellemző a szerfogyasztás, hiszen az életprevalencia érték a fiúknál 23,8\% míg a lányoknál 19,7 százalék 
volt. A jelentésben vizsgált minta szerfogyasztása többnyire csak néhány alkalomra korlátozódik. A megkérdezett serdülök legtöbbje alkalmi fogyasztónak tekinthető, 20-nál többször egyötödük használt már valamilyen tiltott szert. A riasztó számok ellenére egyértelmü javulás látható a négyévenként megismételt jelentések között, hiszen a kutatás azt is megállapította, hogy a különböző szerek elterjedtsége számottevően csökkent, a fogyasztás pedig ritkult (Elekes, 2015).

A felsorolt egészségkockázati tényezők sok esetben sajnos nem járnak egyedül. Ez különösen az alkoholra és a dohányzásra igaz, ez a két faktor különösen összefügg (pl.; Németh, 2011). A nagymintás ifjúsági kutatás szerint is a fiatalok 41 százaléka mind a két szert „élvezi”, ha már valamelyiket kipróbálta.

Sportolók is ki vannak téve az említett káros magatartási formáknak, ugyanakkor a sport számukra egyfajta védő szerepet tölt be; például kevesebbet dohányoznak, mint a nem sportoló társaik (pl.: Agaku és mtsai, 2015). Rájuk is jellemző azonban az alkalmankénti cigarettázás, különösen a csapatsportolók körében (Mikulán és Pikó, 2012). Sajnos az alkoholfogyasztás terén már nem ilyen egyértelmü a kép. A kutatók is ellentétes véleménnyel vannak a tekintetben, hogy a sportolás, hogyan befolyásolja az „ivást”. Egyes kutatók szerint például a sportolók később próbálják ki az alkoholt és kevesebbet is fogyasztanak (Peretti-Watel, Guagliardo és Verger, 2003), mások pedig azt állítják, hogy a sportoló fiúk több alkoholt isznak, mint a nemsportoló társaik (Taliaferro, Rienzo és Donovan, 2010). Mikulán és Pikó (2012) szerint a sportolókra inkább a ritkább, de nagyobb mennyiségű alkoholfogyasztás a jellemző.

\subsection{A serdülőket védő magatartásformák}

A kockázati magatartásformák mellett léteznek ún. egészségvédő (protektív) faktorok is. Ilyen a táplálkozás és a testmozgás. A kutatások azt mutatják, hogy az egészségre a fizikai aktivitás mellett a helyes táplálkozás a leginkább ható tényező (Lim és mtsai, 2012). Így a következő részben ezek hazai hatásait tekintem át a serdülőkre vonatkoztatva.

\subsubsection{Táplálkozás}

A kiegyensúlyozott táplálkozás hiánya nem csak a serdülőkre, de az egész magyar társadalomra jellemző (Fülöp és Szakály, 2008). A túlzott energiabevitel és a gyenge minőségü tápanyagösszetétel napjaink civilizációs betegségeinek (pl.: cukorbetegség, magas vérnyomás) 
kialakulásában hatalmas szerepet játszik (Jafarirad, Mousavi, Fathi és Hormoznejad, 2016). A minőség mellett a táplálék bevitelének mennyisége és rendszeressége is nagyban hozzájárul az egészséges táplálkozás kialakulásához. Hazánkban legtöbben a reggeli, ebéd, vacsora hármasra bízzák a napi energiabevitelt és fóétkezésünk általában az ebéd. Számos tanulmány kiemeli a reggeli fontosságát. Már régóta tudjuk, hogy a reggeli rendszeres kihagyása többféle egészségveszélyeztető magatartással, például a dohányzással és alkoholfogyasztással (KeskiRahkonen, Kaprio, Rissanen, Virkkunen, és Rose, 2003), drogfogyasztással (Affenito, 2007), a fizikailag inaktív életmóddal (Timlin, Pereira, Story és Neumark-Sztainer, 2008) és a sok televízió-nézéssel (Vereecken és mtsai, 2015) is együtt jár. Ezek mellett Ho (2015) taiwani egyetemi hallgatókat vizsgálva megállapította, hogy a rendszeresen reggelizőknek alacsonyabb a vérnyomásuk és jobb tanulmányi eredményeket érnek el. Egy 2014-es felmérés szerint a magyar fiatalok 29,4 százaléka a tanítási napokon soha nem reggelizik és ez az arány nő az évfolyam emelkedésével, azaz a felsőbb évfolyamok felé haladva csökken a napi reggelizések mértéke (Német, 2014).

A kiegyensúlyozott táplálkozás számos egyéb környezeti tényezővel is összefügghet. Például bebizonyosodott, hogy ha a család együtt étkezik, akkor az a fiatalok egészségesebb táplálkozásával jár együtt. (Neumark-Sztainer, Larson, Fulkerson, Eisenberg, és Story, 2010). Egy másik példa szerint az egészségesebben táplálkozók között nagyobb a hajlandóság a rendszeres sportolásra is (Leech, McNaughton és Timperio, 2014).

A fiatalok táplálkozásának legnagyobb rizikófaktora a rendszeres energiaital és gyorsétel fogyasztás. Sajnos ezek igen magas számokat mutatnak a magyar fiatalok körében. Németh (2014) felmérése szerint a fiatalok 8,9 százaléka naponta fogyaszt energiaitalt, mely igen káros a fiatalok egészségre. Több kutatás is kimutatta, hogy a rendszeresen energiaitalt fogyasztóknál jelentősebben nagyobb az esélye a különböző szív és érrendszerbeli megbetegedéseknek (Ruiz és Scherr, 2018).

A táplálkozás témakörében számos tanulmány, disszertáció készült, melyek igen átfogóan ábrázolják a témát. Fontos szem elött tartanunk, hogy a helytelen táplálkozás és a fizikai inaktivitás együttese 10 százalékban lehet oka a betegségek kialakulásának (Lim és mtsai, 2012). Ezért kell kiemelt szerepet kapniuk az iskolai prevenciós programoknak. 


\subsubsection{Fizikai aktivitás}

A fizikai aktivitás szerepe az életmódban kiemelt jelentőséggel bír számunkra. Az egyik legfontosabb egészségvédő magatartásformáról van szó, mely preventív szerepe különböző betegségek kialakulásánál megkérdőjelezhetetlen. Az elmúlt években számtalan elörelépés történt hazánkban a fizikai aktivitás és a sport népszerüsítése terén. Bizonyos társadalmi rétegekben divat lett edzőtermekbe, kondiparkokba, jóga órákra járni.

A serdülők számára a legnagyobb változást az elmúlt években bevezetett mindennapos testnevelés jelenti, melyet felmenő rendszerben kezdtek bevezetni, de immár minden korosztályt érint. A változás nem hozott osztatlan sikert, hiszen több irányból is támadták (infrastrukturális problémákra hivatkozva), ugyanakkor a lakosság több mint 70 százaléka egyetért a mindennapos testnevelés bevezetésével (Borbély, 2014). A bevezetés óta készült kutatások is pozitívan nyilatkoznak róla. Fintor (2017) az észak-alföldi régióban végzett kutatása szerint például a diákok 95 százaléka szereti a mindennapos testnevelés órákat. Kutatásából az is kiderül, hogy a fiúk jobban kedvelik a testnevelés órákat, mint a lányok. Egy másik kutatás a mindennapos testnevelés személetformáló hatására helyezi a hangsúlyt. Nagy és munkatársai (2015) arra következtetésre jutottak, hogy akik többet sportoltak a középiskolában, többet fognak az egyetemi éveik alatt is.

Ahogy láthatjuk, rengetegen diákhoz eljut az iskolai testnevelés keretein belül a rendszeres testmozgás, de sajnos az életkor előrehaladtával folyamatosan csökken az iskolán kívüli testmozgás. Míg például a 15-19 éves diákok 41 százaléka sportol iskolán kívül, addig ez a szám a 25-29 évesek között már csak 33 százalék (Ádám és mtsai, 2018). Úgy látjuk, hogy a fizikai aktivitás nő hazánkban, de jelentős eltérések tapasztalhatóak a különböző korosztályokban és társadalmi rétegek között. Több egymástól független kutatás is sajnos azt támasztja alá, hogy csökken a rendszeres testmozgás a kor elörehaladtával (pl.: Bauman, Merom, Bull, Buchner, és Singh, 2016).

Arra is rávilágítanak a kutatások, hogy a fiatalok több mint fele $(54,6 \%)$ naponta legalább 2 órán keresztül néz valami képernyőt és ez a szám a hétvégére 80 százalék fölé mehet (Ádám és mtsai, 2018). Ezek az adatok azért is fontosak a fizikai aktivitás vizsgálatánál, mivel fordított arányosságban vannak a testmozgással. Azaz míg a rendszeres testmozgás csökken az életkor elörehaladtával, addig például a tv-t nézö fiatalok száma nö. Ez figyelhető meg az okoseszközök tekintetében is. A kutatások arra is rávilágítottak, hogy 
az okostelefon és tablethasználat korosztályonként nem tér el jelentősen (Ádám és mtsai, 2018). Érdekes megvizsgálni, hogy a fiatalok mire használják ezeket a digitális eszközöket, amiben nemenként jelentős eltérések tapasztalhatóak. Ádám és munkatársainak (2018) a kutatásából az látszik, hogy a fiúk 49,7 százaléka játszik tanításai napokon legalább két órát valamilyen játékkal, míg ez a lányoknak mindössze harmadára (29,0\%) jellemző. Az egyértelmüen látszik, hogy a fiúk jelentősen többet játszanak a digitális eszközökön, mint a lányok. Valamennyi korosztálynál szignifikánsan magasabb volt ez az érték a fiúk javára (Ádám és mtsai, 2018). A tanulmányukból az is kitünik, hogy míg a fiúk inkább játékra, a lányok inkább másra használják az okoseszközöket: a fiúk 45,3 százaléka, a lányok 54,6 százaléka használja a tanítási napokon legalább két órán át azokat nem játék céljára (pl.: email, chat, internet; Ádám és mtsai, 2018).

Összefoglalóan elmondhatjuk, hogy a fizikai aktivitás szerepe hazánkban növekszik (köszönhetően a mindennapos testnevelés bevezetésének is), de a testmozgás mértéke folyamatosan csökken az életkor előrehaladtával és helyettük a különböző szórakoztató ipari cikkek (TV, okostelefon, tablet) kerülnek előtérbe. Úgy gondoljuk, hogy a tendencia romlásának megállítása érdekében, fontos tudatosítani a serdülökben helytelen egészségmagatartásukat, hogy később értékes tagjai lehessenek a társadalomnak.

\subsection{A fizikai aktivitás egészségre gyakorolt hatásai}

A rendszeres testmozgás pozitív hatását fizikai egészségünkre számtalan kutatás vizsgálata már. Így elmondhatjuk, hogy a fizikailag aktívabbak nagyobb állóképességgel rendelkeznek (Rauner, Mess, és Woll, 2013), jobban elkerülik őket a mozgásszervi betegségek (Rauner, Mess, és Woll, 2013), immunrendszerük erősebb (Peake, Neubauer, Walsh és Simpson, 2017) fizikailag aktívabbak és hosszabb élettartamban is bízhatnak (Arem és mtsai, 2015). Kutatásom során elsősorban a sport mentális egészségre gyakorolt hatására vagyok kíváncsi, ezért ebben a fejezetben azokat az egészségpszichológiai változókat nézem át, melyekre hatással lehet a fizikai aktivitás.

Az eddigi tudásunk alapján a sport pozitív hatásai között számos pszichológiai jelenséget találhatunk. A rendszeres sportolás fejleszti az önbecsülést, elősegíti a pozitív gondolkodást, fokozza az énhatékonyságot, valamint a belső kontrollt (Mistretta és mtsai, 2017). Ezek mellett pozitív hatással van a szubjektív jóllétre és a jövőorientációra is (Stone, 
Schwartz, Broderick és Deaton, 2010). Az életvitel vizsgálatánál érdemes tisztázni, mit is jelent ez a két fogalom.

A jövőorientáció nem más, mint hogy az egyén stratégiáinak tükrében látja a céljait, terveit, (Nurmi, 1991). A jövőorientáció sokszor nem helyzet-specifikus, hanem egy dimenzióban írja le az egyén jövővel kapcsolatos elképzelését.

A szakirodalom szerint a szubjektív jóllét egyik mutatójának az élettel való elégedettséget tekinti; ,, a szubjektív jóllét az embereknek a saját életükkel kapcsolatos kognitív és érzelmi értékelése” (Martos és mtsai, 2014). Több kutatás is azt mutatja, hogy az élettel való elégedettség lényegesen nagyobb mértékü azoknak az egészséges életvitelü fiataloknak a körében, akik sportolnak és odafigyelnek táplálkozásukra is (Grant és mtsai, 2009). Az ilyenfajta pozitív törekvések a célokra is jó hatással van. Így elmondhatjuk, hogy az egészségtudatosabb fiatalok magabiztosabbak jövőjüket illetően is (Joireman, Shaffer, Balliet, és Strathman, 2012). A jóllét és a célok mellett a sport a hangulatra is jó hatással van. Brosnaan és munkatársai (2004) azt találták, hogy azok a serdülők, akiknek legalább heti 3 vagy több testnevelésük volt, kevésbé voltak szomorúak, mint akiknek ennél kevesebb óra jutott.

Ám ezen pozitív tulajdonságok különbségei nemcsak a sportoló és a nemsportoló fiatalok között figyelhetők meg. Az évek folyamán sok kutatás rávilágított arra a tényre, hogy a különböző sportágak képviselői között is találunk fizikai és mentális eltéréseket. Például Sabiston és munkatársai (2013) kimutatták, hogy a csapatsportokban részt vevő sportolók kevésbé hajlamosak a depresszióra és a lehangoltságra, valamint felnőtt korban hajlamosabbak a rendszeres sportolásra, mint a nem csapatsportágat üző társaik. Mint már említettem, a sport egyik leggyakrabban igazolt pozitív hatása a nagyobb önbecsülés és önbizalom, valamint a jobb társas készségek (Widoni és Ward, 2009). Ugyanakkor egyes kutatások szerint a csapatsportban való részvétel még jobb pszichés státuszhoz vezethet, mint az egyéni sportágak üzése (Eime és mtsai, 2013). A sport jó hatással van a szellemi teljesítményre is. Több kutatás is vizsgálta az egyéni és a csapatban sportolók iskolai teljesítményét, de az eredmények nem egyöntetüek. Shachaf és munkatársai (2013) szerint az iskolai teljesítmény és a sportágak típusa közötti összefüggés csak a fiú csapatsportolóknál mutatható ki, míg egy másik tanulmány szerint, ahol az érettségi eredményeket hasonlították össze a sportágtípusok szerint, azt tapasztalták, hogy az egyéni sportolók értek el jobb eredményeket (Bradley, Keane és Crowford, 2013). 
Eddig a fizikai aktivitás pozitív hatásaira koncentráltam, azonban meg kell jegyezni, hogy a sport hajlamosíthat negatív érzelmi állapotokra, szorongásra, depresszióra, alkalmazkodási zavarokra és káros szenvedélyekre is (Klibert, Lamis, Naufel, Yancey, és Lohr, 2015). Egyes kutatások szerint a perfekcionizmus is ilyen hatásokkal járhat a sportban. Madigan és munkatársai (2016) szerint a perfekcionizmus a teljesítményre negatívan is hathat, mivel a teljesítményszorongás révén a kiégés felé sodorhatja az egyént. Az énképre is negatív hatással lehet a fiatal (különösen az elit) sportolók sikertelensége, mivel ők hajlamosak lehetnek az élet más területeire is rávetíteni a sikertelenséget (Gyömbér és Kovács, 2012). A problémát általában a túl magasra helyezett mérce okozza, melyet a sportolók nem tudnak teljesíteni, így kialakul a szorongás majd a teljesítménycsökkenés.

A sportnak egyaránt lehet pozitív és negatív hatása a mentális egészségünkre. Szakirodalom szerint ezek hatása összefügghet a sportolók motivációjával is. Ezek kapcsolatát a későbbiekben külön fejezetben igyekszem bemutatni. Ugyanakkor az látszik, hogy ez a sportpszichológiában egy fontos, ám nem eléggé feltárt terület. Ezért a sportmotiváció és a mentális egészség kapcsolata disszertációmban külön hangsúlyt kap. Igyekszem feltárni azokat az összefüggéseseket, melyek közvetlen hatással lehetnek a mentális egészségre és a motivációra. 


\section{A SPORTOLÁST BEFOLYÁSOLÓ PSZICHOLÓGIAI TÉNYEZŐK 2.1. A sportmotiváció megközelítései}

A sportmotivációval sokan sokféleképpen foglalkoztak az elmúlt évtizedekben. Több kutatás is készült, ahol csak egyszerü kérdésekkel próbálták a fiatalok és idősebbek sporthoz való viszonyát felfedni. Ezek mellett komplexebb motivációs elméletek is napvilágot láttak, melynek célja, hogy átfogó képet adjanak a sportrészvétel okairól és annak hatásairól. A következőkben ezeket a motivációs elméleteket szeretném áttekinteni, különös tekintettel a klasszikus öndeterminációs modellre (Deci és Ryan, 1985), valamint a disszertációm középpontjában álló sport-elköteleződés modellre (Scanlan, Carpenter, Schmidt, és Simons, 1993).

Ám mielőtt ezeket az elméleteket ismertetném célszerủ tisztázni, mi is az a motiváció. Maga a szó a latin „movere” szóból ered és jelentése mozogni, mozgatni. A pszichológiában ez az embermozgató erőket jelenti. A szakirodalom szerint a motiváció „, a viselkedés és a magatartás kiváltásában, szabályozásban és fenntartásban szerepet játszó tényezők összessége". (Gyömbér és Kovács, 2012, 96. o.) A motivációt a drive hajtja, ez a motiváció belső oka, amely az egyénen kívül történő eseményektől független, olyan viselkedést indít el, mely csökkenti a szükségletet. A motivált viselkedés alapvetően biológiai jellegü, mely a szervezet viszonylagos állandóságán alapul. Például, ha valamilyen hiány lép fel a szervezetben az cselekvésre készteti az egyént, melynek következtében a hiány megszünhet és így visszaállhat az egyensúly. Ez a fajta motívum nem csak az emberekre jellemző. Ugyanakkor ezek mellett vannak csak emberre jellemző motívumok is, mint a kompetencia, teljesítmény vagy az önmegvalósítás. A korai motivációs elméletek is a biológiai szükségleteinkre épültek (pl.: Maslow piramis), ám az évtizedek alatt inkább a kognitív és behaviorista és szociális modellek kerültek előtérbe (pl.: elvárások - értékek, hajtóerők, énhatékonyság stb.; N. Kollár és Szabó, 2004).

A sportmotiváció vizsgálatában is számos motivációs elméletet használtak. Így meg kell említenünk például a flow elméletet, mely a belső motiváció jelenségéből nőtte ki magát, mely Csíkszentmihályi (1997) szerint a flow a teljes bevonódsát jelenti egy cselekvésben. Lock és Latham (1985) a célok irányából megközelített motivációs elmélete is fontos része a szakirodalomnak. Vizsgálatomban azt találták, hogy a céloknak köszönhetően növelhető a teljesítmény és az önbizalom, amely következményeként motiváltabbak lesznek a személyek sportáguk üzésében. A célorientált megközelítés okozhat negatív következményeket is, mivel, 
ha a célok túl magasak és nehéz öket elérni, akkor a sportoló jobban hajlamos a kiégésre és a lemorzsolódásra (Bueno, Wienberg és Fernandez, 2008).

A motiváció mellett az elköteleződés is egy megközelítés a sportolási vágy feltárására. A szakirodalom azt mutatja, hogy a motiváció és az elköteleződés fogalma sok mindenben megegyezik egymással. Pinder (1998) mindkét elemet úgy írja le, mint energizáló erőt, mely a viselkedésre hat. A motiváció központjában a célállítás áll, mely történhet egyszerü szükségletek, személyes értékek vagy külső értékek mentén. Az elköteleződést már nehezebb leírni. Mayer és Herscovitch definíciója szerint az „elkötelezödésen azt az eröt értjük, mely az. egyént cselekvések sorozatával egy bizonyos célhoz segíti." (Mayer és Herscovitch, 2011, 300. o.) A különbséget is talán e két szerző fogalmazta meg legjobban. Ök azt írták le, hogy az elköteleződés egy hosszú távú folyamatot eredményez (pl.: munkavállalás, iskola, házasság stb.), míg a motiváció egy relatíve rövidebb hatású folyamat (pl.: motivált vagyok, hogy jól vizsgázzak, hogy jó jegyeket kapjak) (Meyer és Herscovitch, 2001).

A sportolói identitás is meghatározó szerepet tölthet be a sportolási vágy leírásában. A fogalmat Brewer és munkatársai (1993) vezették be és igyekeztek vele meghatározni az egyén viszonyát egy adott sportághoz. A sportolók identitás vizsgálata külföldön igen népszerü, ezért fontosnak érzem magyar minta vizsgálatát is.

A széleskörü szakirodalmat kutatásomban három elméletre szükítettem le, melyeket a következőkben részletesebben fogok ismertetni. Célom, hogy az olvasó átfogó képet kapjon az öndeterminációs elmélet, a sport iránti elköteleződés és a sportolói identitás fogalmairól. Ezen túl részletesen bemutatom a sportélvezetet, mint az elköteleződést leginkább befolyásoló tényezőt.

\subsubsection{Az öndeterminációs elmélet}

Az öndeterminációs elmélet kihagyhatatlan a motivációt vizsgáló kutatásokban, mivel az egyik legnépszerübb motivációs elmélet napjainkban. Számos környezetben használják, így készültek kutatások az elmélet köré építve a zenészek (pl.: Evans, 2015), dolgozók (pl.: Gagne, 2014) és tanulók motivációjáról (pl.: Wood, 2018) is. Az elmélet eredete Deci és Ryan (1985) nevéhez füződik, akik a három alapszükséglet (autonómia kompetencia, valahova tartozás) köré építették modelljüket. 
A kompetencia szükséglete az egyén hatékonyságára és képességeink kibontakoztatására vonatkozik. Ez a fajta szükséglet sarkallja az egyént arra, hogy képességeinek megfelelő kihívásokat keressen és szinten tartsa és fejlessze a képességeit a tevékenysége során (Deci és Ryan, 2002). Az autonómia szükséglete az én viselkedését és kifejeződését fejezi ki, de ha az eseményeket külső hatások alakítják, akkor azokat megfelelően tudja értékelni és meg tud maradni a kezdeményezőkészsége (Deci és Ryan, 2002). A valahova tartozás iránti vágy nem más, mint a kötődés igénye, amely magába foglalja a másokhoz való kapcsolódást, másokkal való törődést és a mások elfogadását is. A valakihez való kapcsolódás, az elfogadás érzete a lényeges, és nem a viselkedés eredménye (Deci és Ryan, 2002). Deci és Moller (2005) szerint ezeknek a szükségleteknek a kielégítése elengedhetetlen annak érdekében, hogy motivációnk belülről jöjjön és az örömért csináljunk egy adott tevékenységet.

Az öndeterminációs elmélet alapjaiban a belső késztetés (intrinzik) és a külső ösztönzés (extrinzik) dimenzióra osztja a motivációt, hiszen úgy véli, hogy a motiváció mértéke annak helyétől függ. A belső motiváció célja az öröm és az elégedettség érzése, azaz a belső késztetés megléte, míg a külső motivációt a külső, ösztönző hatások befolyásolhatják (pl.: sport tevékenység folytatása a szülői nyomás hatására; pénzbeli jutalom a profi sportolóknál).

Pelletier és munkatársai (1995) tovább gondolták a modellt és megalkották az önmeghatározás elmélet alapján az ún. öndeterminációs kontinuumot (3. ábra), melyet három nagyobb részre osztottak. A modelljükben helyet kap az amotiváció, ahol nincs szabályozás, az extrinzik motiváció négy dimenziója, valamint az intrinzik motiváció, ahol a belső önszabályozás megvalósul.

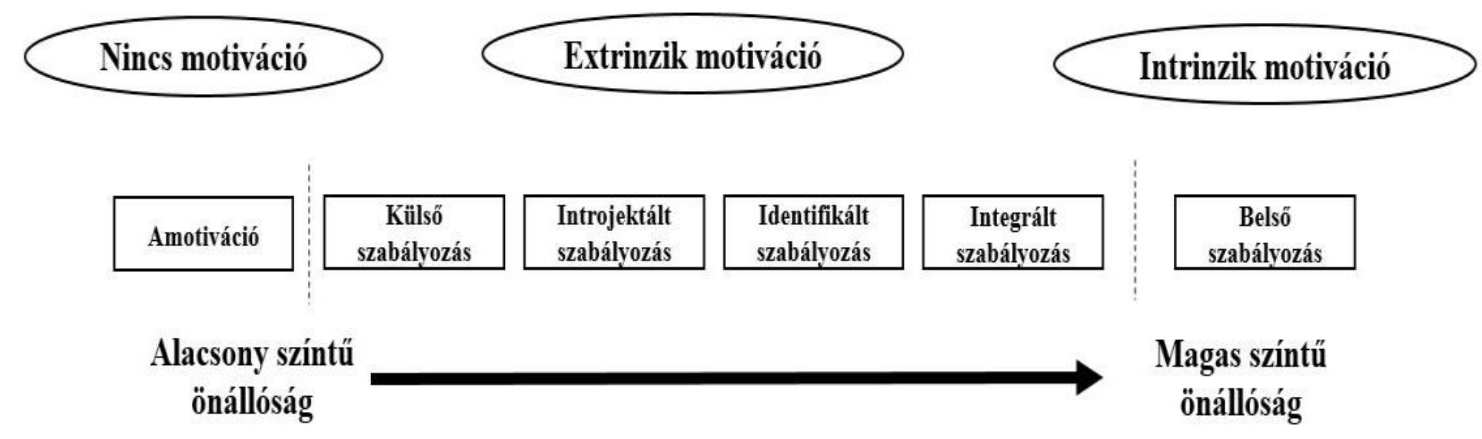

3. ábra. Az öndetermináció elmélet folyamatmodellje (forrás: saját szerkesztés, Deci és Ryan, 2000 alajján) 
Az öndetermináció szintjei:

I. Amotiváció: Nincs szabályozás, azaz a motiváció hiánya a jellemző. Az egyént az inkompetencia érzete és a kontroll hiánya jellemzi. Nem jellemző rájuk sem a külső, sem a belső motiváció.

II. Extrinzik motiváció: Négy fajtáját tudjuk megkülönböztetni. Így a külső szabályozás lépésenként halad az integrált szabályozás felé, mely már közel áll a belső motivációhoz.

II/1. Külsö szabályozás: Olyan viselkedésformákra utal, ahol a viselkedés egy bizonyos külső jutalom elérésre irányul, ami nem csak pénzbeli juttatást jelenthet. Ennél a szabályozástípusnál függ legnagyobb mértékben az ember a külső környezetétől. Ebben az esetben a legkisebb az egyén öndeterminációja, így a különböző cselekvéseit csakis a jutalom vagy a büntetés elkerülése ösztönzi.

II/2. Introjektált szabályozás: Az introjektált (kivetített) szabályozásnál sincs még öndetermináció. Ebben az esetben az egyén részben sajátjává teszi és elfogad egy adott viselkedésformát, de ezek a mozgatórugók nem képződnek le a személyiségébe. Például a sportolás történhet azért, hogy az egyén megszabaduljon büntudatától, hogy nem mozog, vagy hogy csökkentse a stresszt és fenntartsa a magáról alkotott pozitív képet. Ilyen esetekben elsődleges cél a büszkeség, népszerüség, vagy a szégyenérzet megakadályozása az ösztönző a tevékenységre.

II/3. Identifkált szabályozás: Az identifikált szabályozás egy olyan viselkedésforma, amelyet az egyén önként folytat és amelyeket fontosnak és elfogadottnak tekint. Ebben az esetben az egyén számára kulcsfontosságú a cselekvés sikere, így igyekszik megbecsülni a belé fektetett erőfeszítéseket. Például egy sportoló, aki fejlődni szeretne, még akkor sem fogja kihagyni az edzéseket, ha azok megerőltetők és kellemetlenek számára (Gyömbér és Kovács, 2012)

II/4. Integrált szabályozás: Az integrált szabályozásnál már megjelenik az öndetermináció, hiszen ennél a szabályozásnál a legnagyobb az önállóság mértéke. Ilyen esetekben az egyén a saját érdekeit és céljait tartja szem előtt és azoknak igyekszik megfelelni. III. Intrinzik motiváció: A belső motiváció az öndetermináció és az önállóság legtisztább megjelenési formája. Jellemző rá, hogy az egyén a saját öröme, megelégedettsége miatt folytat egy adott tevékenységet, legyen az bármilyen sportág vagy egyéb tevékenység. 
A sport és az öndetermináció kapcsolata:

Számtalan kutatás készült az öndetermináció elmélete és a fizikai aktivitás és sport kapcsolatáról. Pelletier és munkatársai (1995) szerint azok a sportolók, akik saját technikájuk tökéletesítését és az új edzésmódszerek megismerését fontosnak tartják, intrinzik motivációval rendelkeznek. Viszont azok a sportolók, akiknek az önértékelés növelése vagy a szégyenérzet elkerülése fontosabb, extrinzik motivációval rendelkeznek. Náluk különösen nagy jelentősége van a csapattársak által kiváltott identifikációnak.

Az extrinzik motivációnak kettős hatása lehet. Egyrészt a jutalmak fokozhatják a sportolók teljesítményét, viszont fenyegető erővel is bírhatnak, mivel a jutalmak károsíthatják a sportolók belső motivációját az által, hogy sérül a sportoló önálló döntése. Ezek alapján az extrinzik motiváció lehet önmeghatározott vagy nem önmeghatározott. Például, ha valamilyen tevékenység külső tulajdonságait magunk részévé tesszük és elfogadjuk, akkor az extrinzik motiváció öndeterminált lesz. Ebben az esetben az egyén még nagyobb odaadással képes végezni tevekénységeit és elfogadja azon tevékenység értékeit. Ellenkező esetben az egyén úgy érezheti, hogy kényszerítik valamilyen tevékenységre, így a belső szorongás, szégyenérzet vagy esetleges büntudat belső kényszerré válhat (Deci és Ryan, 1985; Ryan és Deci, 2000).

A fejezet célja a Deci és Ryan (1985) által bemutatott öndeterminációs elmélet bemutatása volt. Mivel egy olyan elméletről van szó, amely alapját képezi a motivációs kutatásoknak, ezért fontosnak éreztem, hogy a kutatásomban is kiemelt figyelmet kapjon. A következőkben a sport iránti elköteleződés motivációs megközelítését mutatom be.

\subsubsection{A sport-elköteleződés modell}

A különböző motivációs elméletek eltérő megközelítéssel vizsgálják az egyéni viselkedését. A drive-nak a sportban igen nagy jelentősége van, hiszen azt számos változó befolyásolhatja. Deci és Ryan (1985) rámutatott, hogy a hajtóerők jöhetnek külső vagy belső ingerek hatására. Tara Scanlan és munkatársai (1993) is ezeket a hajtóerőket igyekeztek összefoglalni

modelljükben. Ök kifejezetten sportolókra koncentráltak és céljuknak tủzték ki egy olyan modell felállítását, amely leírja azokat a külső és belső ingereket, amelyek a sportolót befolyásolhatják sportolási vágyában. Ezt a modellt végül sport-elköteleződés modellnek 
nevezték (Scanlan, Carpenter, Schmidt, Simons, Keeler, 1993a), melyet az alábbiakban mutatok be részletesen.

Mielőtt bemutatnám a modell felépítését érdemes megismerni annak keletkezését, melyhez egészen a 80-as évekig Rusbult befektetési modelljéig kell visszamennünk. A modellt az élvezet, alternatívák és a befektetések hármasa adja (Rusbult, 1980a) és vizsgáltak már vele romantikus és baráti kapcsolatokat (Rusbult, 1980b), valamint a munka iránti elköteleződésre is sikeresen adaptálták (Rusbult, 1981; Rusbult és Farrel, 1983). Scanlan és munkatársai is ezt a modellt vették alapul, majd kiegészítették újabb elemekkel. Megalkotásánál úgy látták, hogy a következö fogalmak köré kell építeniük a modellt: vonzerő, alternatívák és a visszatartó erők/gátak.

Rusbult munkásságából kiindulva a kutatók vonzerőként a sportélvezetet azonosították. Az alternatívákhoz az egyéb lehetőségeket vettek, amelyek alternatívái és konkurenciái lehetnek a sportnak. A visszatartó érőkhöz pedig három dolog is került. Az első a különböző befektetések (időbeli, energiabeli stb.), a második a társadalom által követelt elvárások, az utolsó pedig az olyan lehetőségek, melyek csak a sportmozgással járhatnak, de hiányuk gátolhatja az elköteleződést egy adott sportág iránt. Így az publikált modell (4. ábra) öt olyan forrást tartalmaz, melyek feltételezhetően a sport iránti elköteleződés magyarázói lehetnek.

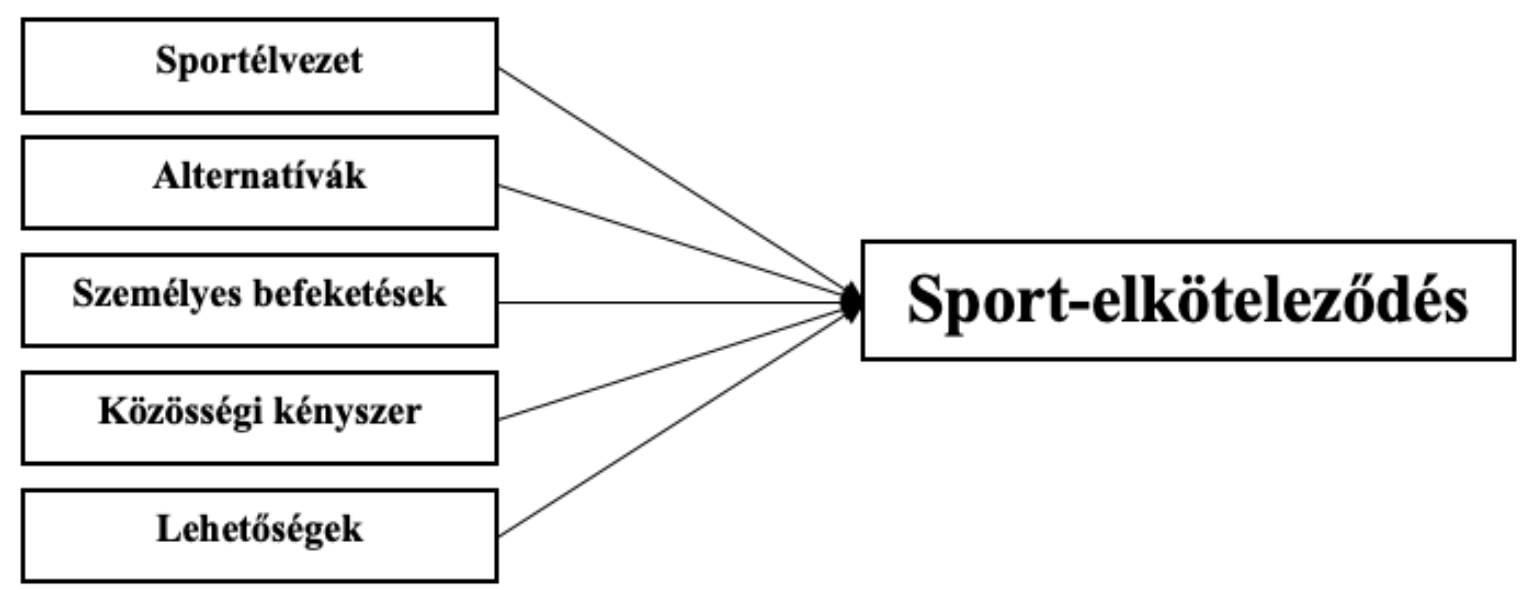

4. ábra. Az első sport-elkötelezödés modell (forrás: saját szerkesztés; Scanlan és mtsai, 1993a)

A korai kutatások azt találták, hogy a magasabb sportélvezet és lehetőségek több befektetéshez is vezethetnek, melyek által nő az elköteleződés is. Ugyanakkor az alternatívák 
és a társadalom által generált kényszer gátolhatják az elköteleződést (Scanlan és mtsai, 1993b).

A kezdeti lendület és eredmények arra sarkalták a kutatókat, hogy tovább vizsgálják az sport elköteleződést konstruktumát, és így a kvantitatív kutatási módszereket kvalitatív interjúk is követték. Scanlan (2003) interjús módszerrel (Scanlan Collaborative Interview Method) profi sportolókat vizsgálva, arra a következtetésre jutott, hogy a megalkotott modellje leírja azokat a legfőbb okokat, melyek az elköteleződéshez vezethetnek. A kutatók újabb lehetséges forrásokat is felfedeztek, amelyek az elköteleződéshez forrásai lehetnek. Ilyenek például a csapat hagyományok, csapattagság vagy közösségi támogatás és a törekvés a fejlödésre források. Utóbbi kettő a kutatások hatására bekerültek a modellbe (Scanlan, Russell, Magyar és Scanlan, 2009). Ezek mellett a kutatások egy másik nézőpontra is rávilágítottak, mégpedig arra, hogy a magas szintü elköteleződés nem csak a vonzerők hatására lehetséges, hanem a kényszer is szerepet játszhat a sportolók elköteleződésében (Gabriele, Gill, és Adams, 2011). A szakirodalom bővülése arra sarkallta a szerzőket, hogy újragondolják a 1993-ban kiadott modelljüket és kiegészítsék azokkal a forrásokkal, amelyek a kutatások szerint a legígéretesebbnek bizonyultak. Így a kutatók 2016-ban publikálták a modell frissített változatát, mely megkülönbözteti a kétfelé elköteleződés típust és annak hét forrását (Scanlan, Chow, Sousa, Scanlan, és Knifsend, 2016; 5. ábra). A kutatások révén a fogalmi kérdések egyre jobban letisztázódtak és némelyik elemnek a nevét átalakították.

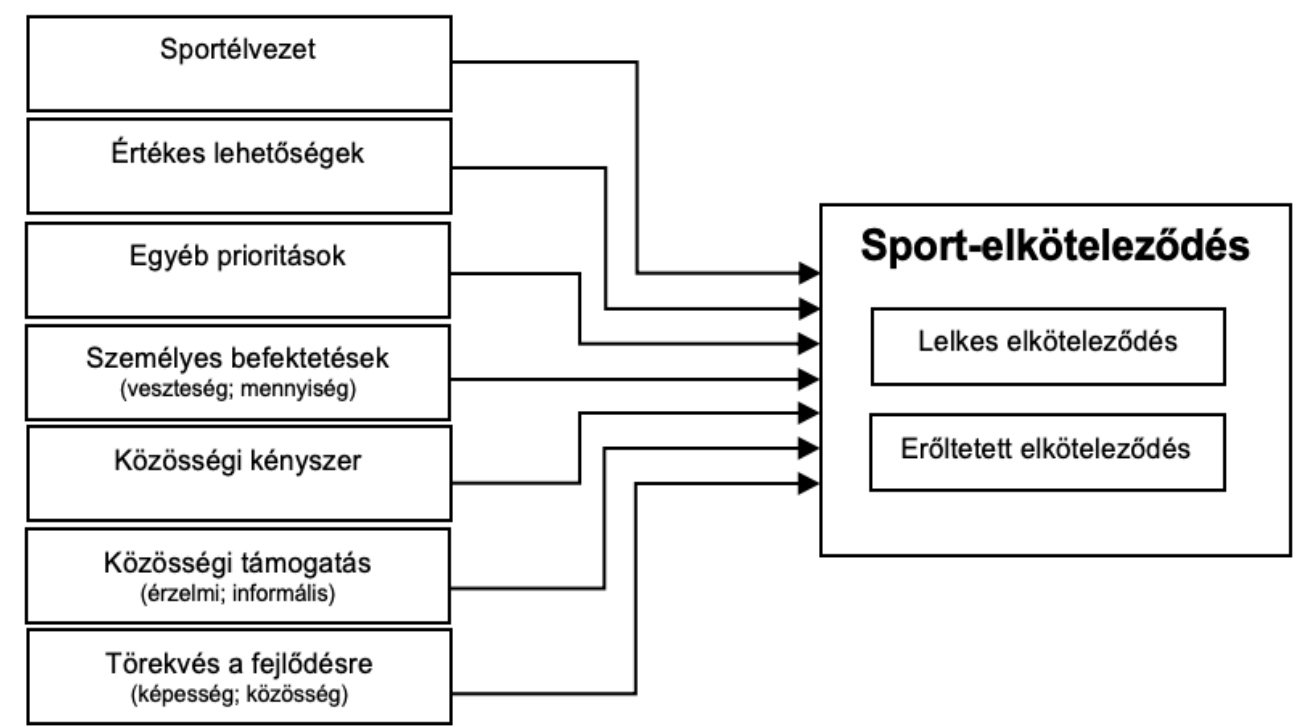

5. ábra. Az új sport-elkötelezödés modell (forrás: saját szerkesztés; Scanlan és mtsai, 2016 alapján) 
A sport-elköteleződés modell elemei:

A következőkben a modellel kapcsolatos kutatások és fogalmak körét igyekszem tisztázni. A jobb érthetőség kedvéért az elköteleződés típusokat és az elköteleződés források fogalmait táblázatos formában is bemutatom (1. táblázat).

\section{1. táblázat. Sport-elkötelezödés modell fogalmi háttere}

\begin{tabular}{|l|l|}
\hline Lelkes elköteleződés & $\begin{array}{l}\text { Egy olyan pszichológiai állapot, amely a sporttevékenység } \\
\text { folytatásához köthető elszántságot és vágyakozást ábrázolja }\end{array}$ \\
\hline Eröltetett elköteleződés & $\begin{array}{l}\text { Egy olyan pszichológiai állapot, amely a sporttevékenység } \\
\text { folytatásához köthető kötelezettséget ábrázolja }\end{array}$ \\
\hline Sportélvezet & $\begin{array}{l}\text { Sport által elért pozitív érzelmi reakció, aminek általános } \\
\text { érzete az öröm. }\end{array}$ \\
\hline Értékes lehetőségek & Lehetőségek, melyek a sport által élhetök meg. \\
\hline Egyéb prioritások & Olyan egyéb tevékenységek, melyek gátolhatják a sportolást. \\
\hline Közösségi kényszer & $\begin{array}{l}\text { Társadalmi elvárások, melyek kötelezettségeket róhatnak az } \\
\text { egyén felé, aki így a sportnál marad. }\end{array}$ \\
\hline $\begin{array}{l}\text { Személyes befektetések - } \\
\text { veszteség }\end{array}$ & $\begin{array}{l}\text { Olyan személyes források, melyeket az egyén elveszít, ha } \\
\text { abbahagyja a sportot. }\end{array}$ \\
\hline $\begin{array}{l}\text { Személyes befektetések - } \\
\text { mennyiség }\end{array}$ & A sportba fektetett személyes források mennyisége \\
\hline $\begin{array}{l}\text { Közösségi támogatás - } \\
\text { érzelmi }\end{array}$ & Bátorítások, segítségek fogadása a sportban másoktól. \\
\hline $\begin{array}{l}\text { Közösségi támogatás - } \\
\text { informális }\end{array}$ & Hasznos információk, tanácsok fogadása a sportban másoktól. \\
\hline $\begin{array}{l}\text { Törekvés a fejlődésre - } \\
\text { képesség }\end{array}$ & Törekvés az egyéni teljesítésre és fejlödésre sportban. \\
\hline $\begin{array}{l}\text { Törekvés a fejlödésre - } \\
\text { közösség }\end{array}$ & Törekvés a gyözelemre, az ellenfelek legyőzésére a sportban. \\
\hline
\end{tabular}

A lelkes elköteleződés fogalma szerint „Egy olyan pszichológiai állapot, amely a sporttevékenység folytatásához köthető elszántságot és vágyakozást ábrázolja” (Scanlan és mtsai, 2016, 235.o.) Jellemző rá, hogy a személy saját maga akar részt venni egy adott tevékenységben. Scanlan (2016) kutatása szerint a lelkes elköteleződésnek a pozitív forrásai a sportélvezet, az értékes lehetőségek és a törekvés a fejlődésre, míg a negatívak az egyéb prioritások. 
Az erőltetett elköteleződést a lelkes elköteleződéssel ellentétben az jellemzi, hogy valamilyen külső nyomásra kell részt venni egy adott tevékenységben. A fogalma nem más, mint „Egy olyan pszichológiai állapot, amely a sporttevékenység folytatásához köthető kötelezettséget ábrázolja" (Scanlan és mtsai, 2016, 235. o.). Az erőltet elköteleződésnek öt forrását azonosították a kutatók, melyek pozitívan és negatívan egyaránt befolyásolják ezt a típusú elköteleződést. Ezek a források a sportélvezet, értékes lehetőségek, egyéb tényezők, a társadalmi kényszer és személyes befektetések voltak.

A kétféle elköteleződésnél több forrás is megegyezik, de ez nem véletlen. A lelkes elköteleződésnél a sportélvezet, értékes lehetőségek, egyéb tényezők hármasa magas értékkel bír. Az erőltetett elköteleződésnél pedig ezek az értékek alacsonyak és a társadalmi nyomás és a társadalmi kényszer, valamint a személyes befektetés rendelkezik magasabb értékekkel. E két elköteleződési típus közötti különbségről még kevés vizsgálat készült, hiszen új modell lévén még kevesen vizsgálhatták. Weiss és Weiss (2003) női tornászoknál már megfigyelte a kétféle elköteleződést, de ő ezt vonzó és csapdába esett elköteleződésnek nevezi.

Az elméleti modellt tovább elemezve a legtöbb cikk azt a konklúziót vonja le, hogy a legfontosabb forrás a sportélvezet. Ezt az eredményt kapták labdarúgók mérésénél (Sausa, 2007), felnőtt teniszjátékosok (Casper, Gray és Stellino, 2007) és egyetemisták megkérdezése során is. (Wilson, Rodgers, Carpenter, Hall, Hardy, Fraser, 2004). Bármilyen szinten is vizsgáljuk a sportélvezetet, legyen az amatőr vagy profi sport, szinte mindig az egyik legfontosabb forrása lesz az elköteleződésnek. Például profi rögbi játékosok azt nyilatkozták, hogy addig fognak játszani, míg azt élvezik (Scanlan és mtsai, 2003). A sportélvezet fogalma szerint nem más, mint a ,, Sport által elért pozitív érzelmi reakció, aminek általános érzete az. öröm.” (Scanlan és mtsai, 2016, 235). A sportélvezet vizsgálatánál elsősorban azt vizsgáljuk, hogy mennyire szeretjük, vagy mennyi örömöt lelünk saját sportágunkban. Mivel a sportélvezetnek igen sok pozitív hatása van, ezért kutatók külön vizsgátokkal igyekeztek az elem forrásait feltárni. Tanulmányomban az elem forrásait a későbbi fejezetekben részletesebben is elemzem.

A szakirodalomból az látszik, hogy a másik fontos elem az értékes lehetőségek, ami azokat a lehetőségeket jelenti, amelyek csak a sporttevékenységek által élhetők meg. Itt elsősorban olyan tevékenységekre kell gondolni, mint az utazási élmény, jövőbeni események, tanulás és a versenyzés élménye. Szinte az összes tanulmány a sport iránti 
elköteleződés pozitív kapcsolatát mutatja, sőt van, ahol ez a leginkább befolyásoló tényező. Fitnesztermek használóival (Zahariadis, Tsorbatzoudis és Crouios, 2002) és egyetemi hallgatókkal (Boyst, 2009) készített felmérésben az látszik, hogy ez a legerősebben befolyásoló tényező. Más tanulmányok meg egyenesen a sportélvezet forrásaként tekintenek rá (Scanlan és mtsai, 2009). Azt érdemes megjegyezni, hogy a két elem erősen korrelál egymással. (Scanlan és mtsai, 1993c). Hobbi teniszezőknél készített kutatásában szintén egy erős forrásként jellemezték az értékes lehetőségeket (Casper, Gray és Stellino, 2007).

Az egyéb prioritások, mint a sport alternatívái kerültek elöször a modellbe. Ezek az alternatívák nem csak egy másik foglalkozás vagy hobbi lehetnek, hanem család, barátok és a tanulmányok is. Scanlanék (2009) elit sportolókat interjú segítségével vizsgálva arra jutottak, hogy a sportolók ezeket nagyon fontosnak tartják, de a sportot nem befolyásolják, (Scanlan és mtsai, 2009) tehát az elit sportban ennek az elemnek nincs nagy jelentősége. Inkább van serdülő korban, ahol a tanulás játssza a fö szerepet, vagy idősebb korban, ahol már a család az első. Például Sousa (2007) serdülő labdarúgókat vizsgálva megállapította, hogy ha az egyéb prioritások előtérbe kerülnek, csökken a sport iránti elköteleződés. Fiatalabb gyerekek esetében már nehezebben értelmezhető ez a fogalom, (Scanlan és mtsai, 2003) mivel a gyerekek nem tudják elképzelni milyen egyéb alternatívák lehetnek a sporton kívül. Az egyéb tényezők lehetnek vonzóak és szorongatóak, melyek gátolhatják a sporttevékenység folytatását. A vonzóak (attraktív) pl.: zenekar, barát, barátnő, család. A szorongatók lehetnek például a munkahely, tanulás, de lehet család, barátnő és a barát is (Scanlan és mtsai, 2009).

A személyes befektetéseknél a szakirodalom nem elsősorban anyagi befektetésre helyezi a hangsúlyt, hanem azt próbálja megértetni, hogy időben, energiában és erőfeszítésben mennyit áldoztunk egy adott sportágra. Scanlan és munkatársai (2016) kétféle személyes befektetést különböztet meg. Az egyik a mennyiségi. Lényege, hogy mennyit fektetünk a sportba. A másik a „loss”, azaz veszteség, aminek lényege, hogy aki abbahagyja a sportot az elveszítheti az addig belefektetett energiát. Teniszezőknél készült vizsgálatban azt találták, hogy ez az elem a legerősebb forrása az elköteleződésnek (Casper és mtsai, 2007). Ennek egyik okát abban látták a kutatók, hogy a tenisz egy drága és időigényes sport, és mivel a sportolók sok időt, energiát és pénzt fektetnek sportágukba, ezért az növelte az elköteleződésüket. Hasonlóra jutott Wang (2016) is, aki felnőtt táncosokat vizsgált és az 
eredményét azzal magyarázta, hogy idősebb sportolóknál fontosabb a befektetett energia mennyisége, mint más tényezők. A szakirodalomból leginkább az látszik, hogy ez az elem főleg az idősebb korosztályokban hozott szignifikánsan pozitív kapcsolatot az elköteleződéssel (Casper és mtsai, 2007; Chu és Wang, 2012; Wang, 2016).

A közösségi kényszer olyan közösségi norma vagy elvárás, amely kötelezettségeket róhat, az egyén felé, ami által a sportnál maradhat. Lényege, hogy az egyének valaki más miatt sportolnak, akik lehetnek edzők, barátok családtagok stb. A társadalmi nyomásnál az feltételezhető, hogy növekszik a sport elköteleződés, de a vizsgálatok azt mutatják, hogy vagy nincs kapcsolat, vagy enyhén negatív kapcsolat jön létre a két elem között (Carpenter és Coleman, 1998). Ennek oka az lehet, hogy a fiatal sportolók azért sportolnak, mert szeretik és élvezik azt, és nem kényszeríti őket senki. A kutatók vizsgálták az olyan eseteket is, ahol az egyének azért sportolnak, mert muszáj nekik. Carpenter és munkatársai (1993) kutatása azt találta, hogy társadalmi nyomásnak vagy nincs, vagy negatív szerepe van a sport iránti elköteleződésben. A hobbiteniszezők (Casper és mtsai, 2007) körében készült felmérés is hasonló eredményt mutat, amit a kutatók azzal magyaráztak, hogy a hobbiteniszező magáért a mozgás öröméért sportol. Ezen kutatásokkal ellentétes Wiess és Weiss (2003) női tornászokkal készült vizsgálata, ahol azt találták, hogy a sportolók addig nem hagyják abba, míg barátnőik is folytatják a sportot. A szakirodalomban egy másik kutatás is található, ahol a társadalmi nyomás pozitívan befolyásolja a sport iránti elköteleződést. Casper és Andrew (2008) sportösztöndíjas teniszezőknél azt tapasztalták, hogy a teniszezők magasabb társadalmi nyomással és alacsonyabb sportélvezeti értékekkel rendelkeznek. Majd ezekből az eredményekből arra következtettek, hogy ez egy kényszerből végzett tevékenység, mely inkább az erőltetett elköteleződés forrása lehet.

A közösségi támogatás azokat a bátorításokat és támogatásokat jelenti, amelyeket a sportoló a közvetlen környezetétől kap. A támogatás lehet érzelmi és informális. Érzelmi támogatás elsősorban a családtól jön és empátiát és törődést tartalmaz. Az informális, olyan tanácsokat tartalmaz, amelyek segíthetnek problémák kezelésében, az ilyenfajta támogatások leginkább az edzőktől érkeznek. Több kutatásban is az látszik, hogy a közösségi támogatás szignifikáns forrása az elköteleződés, de ez a kapcsolat gyenge és nem egyértelmü. (Weiss, Weiss és Amorose, 2010; Casper és mtsai, 2007). A profi sportolók azonban azt nyilatkozták, 
hogy a bátorítások és támogatások hatással vannak az elköteleződésükre (Scanlan és mtsai, 2003).

A törekvés a fejlődésre forrást Scanlan interjús kutatásai révén elit sportolóknál fedezte fel (Scanlan, Russell, Scanlan, Klunchoo és Chow, 2013). Két dimenzióját különböztetjük meg. Az egyik az egyéni képességbeli teljesítés, mely azon törekvéseket jelenti, melyekkel egy adott sportban minél jobbak akarunk lenni, függetlenül az ellenfelektől. A közösségi teljesítés, pedig azokat a törekvéseket tartalmazza, ahol valakit le akarunk győzni. Erről az elemről csak nagyon kevés vizsgálat készült, de úgy tủnik, hogy a lelkes elköteleződést pozitívan támogatja (Scanlan és mtsai, 2016). Fontos megjegyezni, hogy ez az elem sokban hasonlatosnak látszik, egyéb motivációs elméletekhez, mint az ún. „Achivement goal Therory”-ra (Duda és Treause, 2010). Ezek a hasonlóságok azonban, ha jobban megnézzuik, igen eltérnek. Míg például a Duda és Treasue-féle modell arra fókuszál, milyen sikeresek a sportolók addig, a Scanlanék (2009) eleme inkább az eredmény elérésének a törekvésére helyezi a hangsúlyt.

Összefoglalásképpen elmondhatjuk, hogy a sport iránti elköteleződésben leginkább befolyásoló tényező a sportélvezet, értékes lehetőségek és a személyes befektetések, valamint erősíti az elköteleződést a közösségi támogatás lehet. Az egyéb tényezőkben leginkább a felnőtt és serdülő sportolóknál található negatív kapcsolat. A társadalmi kényszer kevés esetben bizonyult pozitív forrásnak, de akkor is inkább az erőltetett elköteleződést támogatta. Új elem révén a törekvés a fejlődésre elemről még kevés vizsgálat készül, de úgy néz ki, hogy leginkább profi sportolók elköteleződésének a forrása lehet.

\subsubsection{A sportélvezet}

A sportélvezetről, mint a sport iránti elköteleződés legfontosabb forrásáról, külön kutatások és modellek láttak napvilágot. A szakirodalom a különböző elméletek révén, egységesen állítja, hogy a belülről jövő akarat és élvezet elengedhetetlen bármilyen tevékenység űzéséhez. Ezt a tételt állítja Deci és Ryan (1985) öndeterminációs elmélete is, akik úgy tekintenek az élvezetre, mint magára a belső motivációra. Ugyanakkor a sportélvezettel kapcsolatos kutatásokban nem csak belső, hanem a külső tényezőket is megfigyeltek.

Egy korai kutatás szerint elit jégtáncosokat vizsgálva arra jutottak a kutatók, hogy a sportélvezet forrása maga a tevékenység lehet, amelyet az egyén folytat, amely a magas szintü 
mozgásélményben nyilvánulhat meg, illetve, hogy megmutathatják a környezetüknek milyen jók is valójában. Továbbá azt is megállapították, hogy a különbözö emberi kapcsolatok megléte is fontos forrása lehet a sportélvezetnek (Scanlan, Ravizza és Stein, 1989). Mcarthy és munkatársai is hasonló eredményekre jutott utánpótlás korú sportolók vizsgálatánál. Tanulmányunkban egyetértettek, hogy a mozgásélmény fontos forrása a sportélvezetnek (McCarthy, Jones és Clark-Carter, 2008). Egy másik kutatásukban serdülő sportolókat vizsgáló tanulmányban 5 különböző sportélvezeti forrást neveztek meg, melyek az érzékelt képesség, a pozitív csapattársi támogatás, a pozitív szülői háttér, az erőfeszítés és küzdés, valamint a pozitív edzői háttér voltak. Olyan változókat is igyekeztek kutatásukba belevinni, mint az életkor, valamint szülői és edzői kapcsolatok. (MacDonald, Coté, Eys és Deakin, 2011) A 9-14 éves fiú birkózóknál azt tapasztalták, hogy a fiatalabb gyerekek jobban élvezik a sportot, mint idősebb társaik, valamint a szülői és edzői biztatás a szezon alatt is magasabb élvezethez vezet. A testnevelés óra élvezeti forrásait Hashim és munkatársai (2008) próbálták keresni arra jutottak, hogy a sportmozgás által kiváltott izgalom a leginkább befolyásoló tényező. Érdemes még megemlíteni Jaakkola Ntoumanis és Liukkonen (2015) vizsgálatát, ahol finn jégkorongozó gyerekeket vizsgálva azt találták, hogy a sportélvezet legfőbb forrásai a belső faktorok úgymint a teljesítőképesség vagy a mozgásélmény. Ezeket szorosan követték az olyan közösségi elemek, mint a például a barátokkal való találkozás. A kutatók úgy látták, hogy a külső faktoroknak (pl.: győzelem, mások általi dicséret) kevesebb jelentősége van az élvezeti forrásokban.

Wiersma (2001) a sportélvezet forrásait vizsgálva egy kétdimenziós modellt alkotott. A modelljében megkülönböztetett egy teljesítménnyel összefüggő és teljesítménytől független, valamint egy intrinzik és extrinzik tengelyt. A két tengely mentén összesen hat forrást állapított meg, melyeket a 6. ábra szemlélteti. Wiersma egy 896 fős mintán vizsgálva arra következtetett, hogy a saját kompetencia megtapasztalása, valamint a versenyzés izgalma volt a két leginkább meghatározó forrás. 


\section{TELJESITTMÉNNYEL ÖSSZEFÜGGŐ}

\begin{tabular}{c|l} 
Saját kompetencia & Másokhoz viszonyított kompetencia \\
\cline { 2 - 2 } INTRINZIK EXTRINZIK & \\
\hline Veröfeszítés jutalma & $\begin{array}{l}\text { Csapatszellem } \\
\text { Szülői támogatás }\end{array}$ \\
&
\end{tabular}

\section{TELJESITMÉNYTŐL FÜGGETLEN}

6. ábra. Sportélvezeti modell (forrás: saját szerkesztés; Wiersma, 2001 alapján)

A modelljében a „,intrinzik - teljesítménnyel összefüggő „,negyedbe a mozgásélmény és az önfejlesztés került saját kompetencia néven. Az „extrinzik - teljesítménnyel összefüggő” negyedbe olyan elemek kerültek, amelyek a mások legyőzésében és mások általi elismerésben nyilvánulnak meg. Az „,intrinzik - teljesítménytől független” negyedben pedig az energiabefektetés, valamint a versenyzés élménye került. Az utolsó negyedbe az „extrinzik teljesítménytől független" negyedbe a különbözö társas kapcsolatok kerültek, mint a közösségi élmény, valamint a szülöi támogatás (Wiersma, 2001).

Összefoglalásképpen elmondhatjuk, hogy a sportélvezet forrásai külső (pl.: kortársak legyőzése) vagy belső (pl.: mozgás élmény) elemekből állhatnak, illetve lehetnek teljesítménnyel összefüggő (pl.: mozgásélmény) és teljesítménytől független (pl.: szülöi bíztatás) elemei is. A kutatásokból leginkább az látszik, hogy a mozgásélmény és teljesítőképesség elengedhetetlen a magas szintủ sportélvezethez.

\subsubsection{A sportolói identitás}

Az öndeterminációs elmélet és a sport-elköteleződés modell mellett kutatásunkban az identitás is helyet kap, mivel az említett elméletekhez hasonlóan az identitás mértéke is segíthet eldönteni, hogy az egyén mennyire kötődik egy adott tevekénység iránt.

Az identitás, vagyis az én-azonosság az egyik legfontosabb pszichikus közvetítő konstrukció az egyén és a társadalom között, mely nagyban segíti a serdülök szocializációját 
(Pataki, 1982). Kutatások azt mutatják, hogy az identitás formálódását számos tényező befolyásolhatja, mint a barátok (Weiss, Wood, 2005), a család (Deephouse, Jaskiewicz, 2013), a zene (Tekman, Hortacsu, 2002) vagy a sport (Brewer, Van Raalte, Linder, 1993). A tanulmányok már számos alkalommal igazolták, hogy a sportnak igen magas szintü jellemformáló hatása van a serdülőkre. Mint már említettem, a rendszeres testmozgást végző serdülők magasabb önértékeléssel (Baker, Little, Brownell, 2003), jobb tanulmányi eredményekkel rendelkeznek (Van Dusen és mtsai, 2011), valamint egészségesebbek és védettebbek a különböző rizikófaktoroktól (pl.: dohányzás, alkohol), mint kevésbé aktív társaik (lásd pl. Mikulán, 2007). A felsorolt pozitív jellemformáló hatások miatt, úgy gondoljuk, hogy a sportolói identitás meghatározó szerepet tölthet be a tanulók sportolási szokásaiban és a sportmotivációban, ami közvetett hatással lehet az egészségmegőrzésre és a testi-szellemi fejlődésre is.

A sportolói identitás fogalmát Brewer, Van Raalte és Lindner (1993) vezették be. Szerintük a sportolói identitás „a sportolói szerep egyéni identitásba való beépülésének mértéke” (Brewer, és mtsai, 1993; 237). A nemzetközi szakirodalomban a sportolói identitás kutatása igen népszerü és számos összefüggését tárták fel az elmúlt 20 évben. Az eddigi eredmények alapján a sportolói identitás kihat a személyiségfejlődésre, a megfelelő egészségmagatartás kialakulására és a motivációkra is. Többek között, Martin, Fogarty és Albion (2013) vizsgálatából derül ki, hogy az erőteljesebb sportolói identitással rendelkezők pozitívabb szubjektív jólléttel rendelkeznek, ráadásul ez a jóllét akkor is megmarad, ha a sportoló önként és nem sérülés vagy a kiégés miatt hagyja abba a versenysportot. Egy másik vizsgált azt hangsúlyozza, hogy minél nagyobb fokú a sportoló identitás, annál többet sportol az illető (Lamont-Mills, Christensen, 2006), melynek köszönhetően a sportolók magabiztosabbak, és kevésbé érinti őket a kiégés problémája (Burns, Jasinski, Dunn, Fletcher, 2012).

A sportnevelés szempontjából kiemelt jelentősége van a sportolói identitás és a sportmotiváció kapcsolatának, ezért ez az összefüggés számos kutatás középpontjába került. Wilson és Moun (2008) szerint a magasabb pszichológiai szükséglet nagyobb fokú identitáshoz vezet. Egy másik tanulmány arról ír, hogy az öndeterminációs elmélet és az identitás között számos kapcsolat található, hiszen mind a két koncepció a viselkedésre jellemző elemekre épül (pl.: énközpontúság, önszabályozás; Vlachopoulos, Kaperoni és Moustaka, 2011). Ezen 
kutatások szerint a sportolói identitás és az öndetermináció között erős korreláció tapasztalható, és az különösen nagy az identifikált és az integrált szabályozás között (Strachan, Fortier, Perras, és Lugg, 2013; Vlachopoulos és mtsai, 2011). Ez arra enged következtetni, hogy a sportolói identitás a belső és a külső motivációkból egyaránt merítheti az erejét.

Az identitás számunkra is kiemelt jelentőséggel bír, hiszen a sportolói identitás szoros kapcsolatban lehet más modellekkel, így a sport iránti elköteleződéssel is, melyről még nem készült átfogó tanulmány. Ezek alapján, úgy vélem, hogy különböző motivációs elméletek egyegy aspektusból történő vizsgálata segíthet megérteni, hogy milyen tényezők támogatják vagy gátolják a serdülőket sportolási szokásaik kialakulásában.

\subsection{A perfekcionizmus megközelítései és jelentősége a sportnevelésben}

A tökéletességre törekvés mint személyiségjegy fontos meghatározója lehet a versenyszellemnek, a fejlődésre való igénynek, a győzni akarásnak (Stoeber és Otto, 2006). A teljesítmény és a perfekcionizmus kéz a kézben jár, talán emiatt is áll a sportpszichológia egyik fókuszában. Ugyanakkor meg kell jegyezni, hogy a pszichológia más területein gyakran diszfunkcionális jegyként tartják számon, amely hajlamosít negatív érzelmi állapotokra, szorongásra, depresszióra, alkalmazkodási zavarokra, káros szenvedélyekre (Klibert és mtsai, 2015). A teljesítményre is negatív hatással lehet, hiszen az ún. teljesítményszorongás révén az egyén nem bízik eléggé magában, fél attól, hogy hibázni fog, ami jelentős stresszt generál (Dobos és Pikó, 2017). E kettős megítélés vezetett ahhoz a felismeréshez, hogy a perfekcionizmus valójában egy összetett jelenség, amennyiben létezik adaptív és maladaptív, azaz pozitív és negatív perfekcionizmus (Terry-Short, GlynnOwens, Slade és Dewey, 1995). Míg az előző esetben az egyén elvárásai reálisak, észszerüek, önismereten alapulnak, az egyén ismeri saját erősségeit és korlátait. Az utóbbi irreális elvárásokon alapszik, nem reális célokat kitüzve maga elé, ami együtt jár a hibák elkövetésétől való erős félelemmel. Sokan a kora gyermekkori nevelési hibákból eredeztetik: amikor a gyermek nem kap elég pozitív vagy egyértelmü visszajelzést, vagy feltételes elfogadást tapasztal a szülei részéről, önértékelése bizonytalanná válik, hiszen úgy érzi, csak akkor szeretik, ha tökéletesen viselkedik (Currant és mtsai, 2017).

Miután felismerték, hogy a perfekcionizmus többdimenziójú konstruktum, a kutatók igyekeztek meghatározni az elemeit. Frost és munkatársai (1990) hat dimenziót különítettek el: 
hibák miatti aggodalom, önmagunkkal szembeni (személyes) elvárások, szülői elvárások, szülői kritika, viselkedés miatti kételyek, összeszedettség (rend iránti vágy). Ezek összefüggése, kapcsolata különböző lehet a teljesítménnyel vagy a negatív és pozitív érzelmi állapotokkal. Az önmagunkkal szembeni magas elvárás, a hibák miatti aggodalom és a viselkedés miatti kételyek például, kifejezetten hajlamosíthatnak szorongásra vagy depresszióra (Limburg és mtsai, 2017). Azonban a viselkedés miatti kételyek és a hibák miatti aggodalom ronthatják az énhatékonyságot és az élettel való elégedettséget. Az önmagunkkal szembeni elvárások csakúgy, mint az összeszedettség igénye akár pozitív drive is lehet, és bizonyos esetekben az énhatékonyságot növelheti (Dobos és Pikó, 2018). Levine és Milyavskaya (2018) ezzel kapcsolatban azt is feltételezik, hogy a perfekcionizmus nem minden esetben a személyiség meghatározó és stabil jegye, olykor akár csak az élet egy-egy specifikus területére is vonatkozhat. Ráadásul míg egyes kutatók hajlamosak arra, hogy negatív/pozitív, illetve adaptív/maladaptív dichotómiában gondolkodjanak a perfekcionizmusról, valószínúleg mennyiségbeli eltérések is befolyásolhatják az összefüggéseket (Stoeber és Otto, 2006).

A sportpszichológia alapvetően különbséget tesz a tökéletességre törekvés (PS, perfectionistic strivings) és a tökéletesség miatti aggódás (PC, perfectionistic concerns) között, amelyek a sportteljesítményre is eltérő hatással lehetnek (Hill és Madigan, 2016). Az ún. háromoldalú modellben (7. ábra; Stober és Otto, 2006) a kétféle megközelítés három kombinációja alapján három személyiségjegyet különítettek el: egészséges perfekcionisták (magas PS és alacsony PC), egészségtelen perfekcionisták (magas PS és magas PC), valamint nem-perfekcionisták (alacsony PS és magas vagy alacsony PC). 


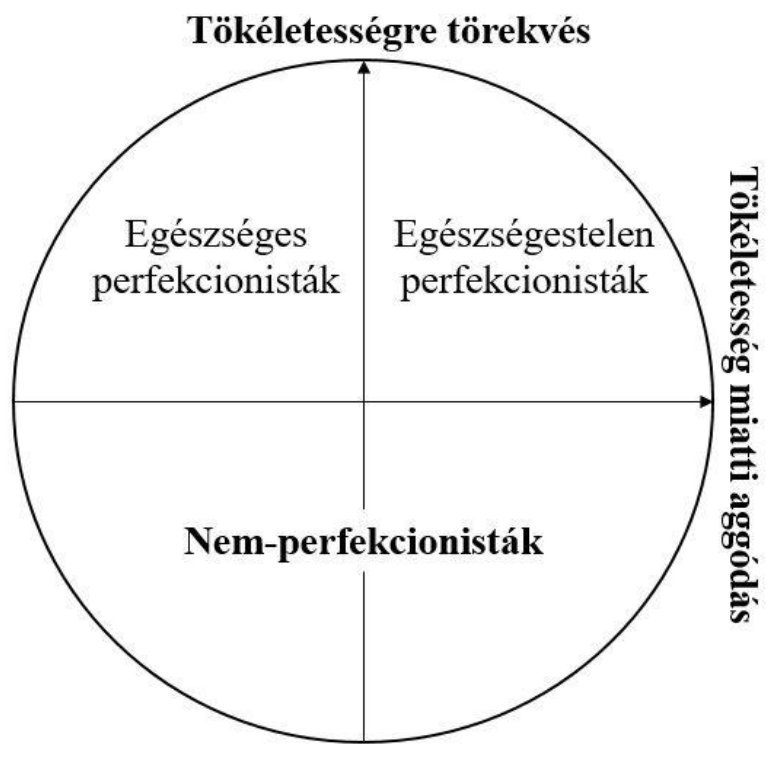

7. ábra. A perfekcionizmus háromoldalú modellje (forrás: Stoeber és Otto, 2006, 296.o.)

Egy másik megközelítésben, az ún. 2 X 2-es modellben négy sportolói csoportot azonosítottak (8.ábra): nem-perfekcionisták (alacsony PS és alacsony PC), tisztán személyes standardokon alapuló perfekcionisták (magas PS, alacsony PC), tisztán önértékelésen alapuló perfekcionisták (alacsony PS és magas PC) és kevert perfekcionisták (magas PS és magas PC)
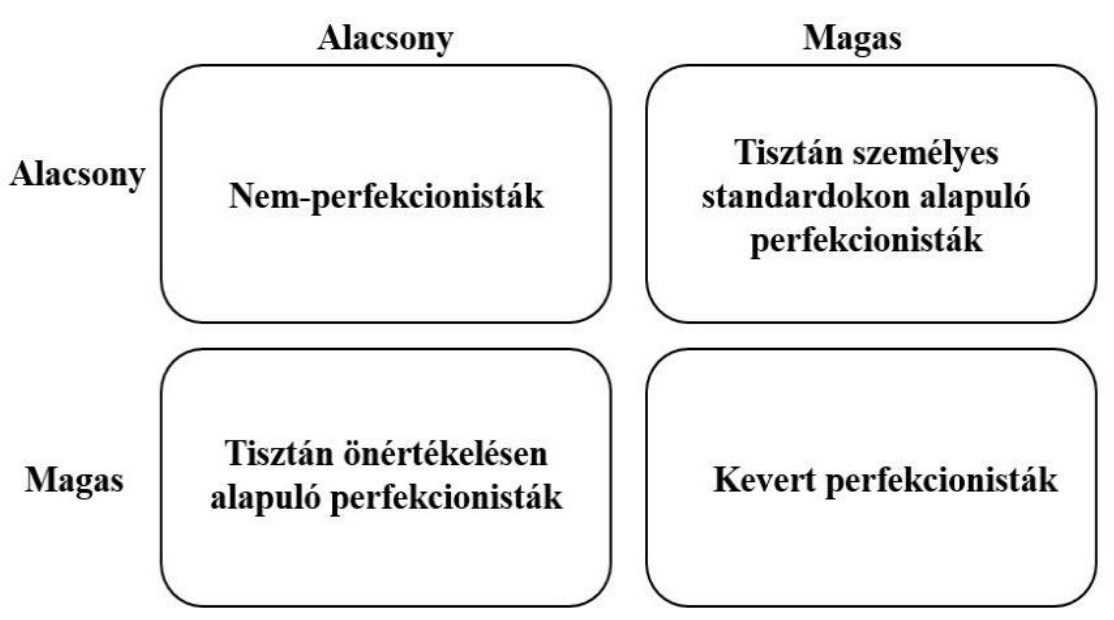

8. ábra. A perfekcionizmus $2 \times 2$-es modellje (forrás: saját szerkesztés Guandreau és Thompson, 2010 alapján.) 
Ezek a sportolói csoportok különböztek a kiégés, a belső motiváció, a pozitív és negatív érzelmek, valamint a sportolói önbecsülés szerint (Hill és Madigan, 2016). A felsorolt modellekről kevés olyan kutatás készült, ahol a perfekcionizmus és a sport iránti elköteleződés közötti összefüggésekre világítanának rá. Jelen kutatásomban ezért ennek feltérképezésére is törekszem.

\subsection{Az egészségpszichológiai elméletek összefüggései és jelentősége az egészségnevelésben}

Tanulmányomban a mentális és fizikai egészségnek kiemelt szerepe van, melyhez egyaránt hozzátartozik a szubjektív jóllét, az egészségattitüdök, az életcélok, azaz aspirációk, a motiváció, valamint ezek kapcsolata.

A szakirodalomban föleg az öndetermináció, a fizikai és mentális egészség kapcsolatáról találhatunk információkat. Az összefüggések elsősorban a három pszichológiai szükségletre (kompetencia szükséglete, egyén hatékonyságára, képességeink kibontakoztatása) és a különböző egészségmagatartási tényezők közötti kapcsolatra fókuszálnak. Például Ng és munkatárasai (2012) megállapították, hogy a pszichológiai szükségletek kielégülése magasabb pszichés jóllétel járhatnak, ami együtt jár a pozitív egészségmagatartás meglétével is. A szükségletek kapcsolatban állhatnak továbbá a mentális egészséggel is, azaz a magasabb öndetermináció alacsonyabb depressziót, szorongást és nagyobb életszínvonalat eredményezhet (Ryan, Patrick, Deci és Williams, 2008). A jóllét és a magas öndetermináció kapcsolatát többen is vizsgálták már. Valamennyien arra jutottak, hogy a magasabb öndetermináció magasabb élettel való elégedettséghez vezet (pl.: Milyavskaya és Koestner, 2011). Ezek mellett egy érdekes tanulmány rávilágít arra is, hogy a magasabb öndetermináció a fogászati szokásokkal is pozitív kapcsolatban van (Halvari, Bjørnebekk és Deci, 2010).

Az öndeterminációs elmélet összefüggést mutat az egyén aspirációival is. Kasser és Ryan (1996) szerint a pszichológiai szükségletek alapján az egyén intrinzik (tartalmas emberi kapcsolatok, személyes fejlődés, társadalmi elköteleződés) és extrinzik (hírnév, gazdagság, külső megjelenés) aspirációval rendelkezik. Ryan és Deci (2017) szerint a különböző egészségmagatartási elemek összefüggenek, így akinek magasabb az intrinzik aspirációja, magasabb szubjektív jóléttel is rendelkezhet, valamint nagyobb szerepet játszanak számukra a személyes célok is (Sheldon, Ryan, Deci, és Kasser, 2004). A pozitív motivációs környezet a 
sportban is kulcsfontosságú a mentális egészség szempontjából. A témában kevés kutatás készült, de például Cronin és Allen (2015) arra mutatott rá, hogy az edzők által kialakított pozitív motivációs környezet összefügg a szubjektív jólléttel.

A motiváció és az egészségmagatartás vizsgálatánál meg kell említeni Ryan és munkatársainak a (2008) modelljét (9. ábra), ahol igyekeztek ábrázolni a pszichológiai szükségletek hatásait a mentális és fizikai egészségre, valamint a szükségletekre ható változókat. A modell elsősorban az egészségügy számára készült, de bizonyos részei számomra is hasznos információt nyújthatnak.

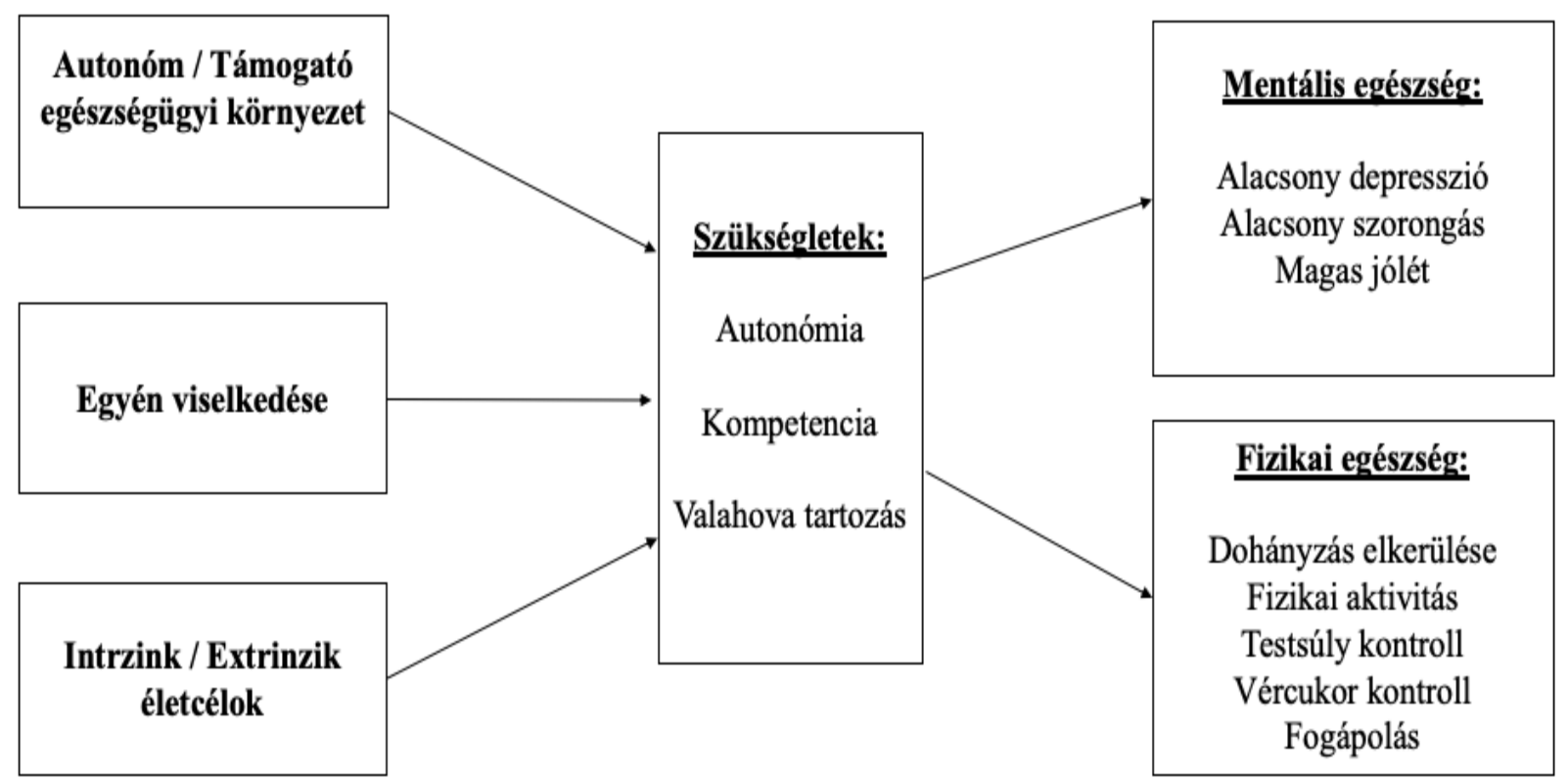

9. ábra. Az öndeterminációs elmélet és az egészségmagtartás változása

A kutatók taglalják a már említett összefüggéseket, így a modell szerint az egyén kompetencia szükségletét, az autonómiáját és a valahova tartozást befolyásolja az autonóm (egyéni döntésen alapszik: „Részt veszek a szürővizsgálatokon, hogy egészséges legyek.”) és a támogató (valamilyen külső nyomáson alapszik: „Részt veszek a szürővizsgálatokon, mert jutalmat kapok érte.”) egészségügyi környezet, az egyén viselkedése, érdeklődése és értékei, valamint az intrinzik és extrinzik életcélok. Amikor az egyén úgy érzi, hogy ezek a hatások érvényesülnek az hat az öndeterminációra és így közvetett módon összefüggés mutatható ki a mentális (alacsonyabb depresszió, szorongás, jobb életszínvonal stb.) és a fizikai egészséggel (káros szenvedélyek, fizikai aktivitás stb.) is. Ahogy láthatjuk, a modell az egészséget és a 
motivációt különböző nézőpontokból vizsgálja. Számomra elsősorban a mentális egészséggel való kapcsolata a fontos, mely kutatásomban is elötérbe kerül. Ugyanakkor a modell nem tér ki például egyéb mentális viselkedés kérdésére (pl.: perfekcionizmus), így az elméletet kutatásomban fenntartásokkal kell kezelni.

A perfekcionizmus vizsgálatoknál leginkább a kiégéssel szokták azonosítani, azonban számos összefüggést is kimutattak már a kutatók a motivációval kapcsolatban is. A perfekcionizmust nem egyszerü kontrollálni, azonban Barcza-Renner és munkatársai (2015) arra világított rá, hogy az edzők hozzáállása kapcsolatban van a perfekcionizmussal és a motivációval. A tanulmányuk szerint az egyén túlzó elvárásai összefüggést mutatnak az amotivációval. Az alacsony elvárosok inkább a kevésbé perfekcionistákra jellemző, ők az intrinzik motivációval állnak szorosabb kapcsolatban a kutatás szerint. Egy másik tanulmány is hasonló eredményeket talált egyetemi hallgatókat vizsgálva (Miquelon, Vallerand, Grouzet és Cardinal, 2005).

Összefoglalás képpen elmondhatjuk, hogy a motiváció, a szubjektív jóllét a jövőbeli célok és aspirációk, valamint az egészségattitüdök összefüggnek, ám ezt a kutatók csupán az öndeterminációs modellel összefüggésben vizsgálták. Az egészségpszichológi és a sport iránti elköteleződés már egy kevésbé vizsgált terület, ezért összefügéseinek feltárása segítheti a sportolói személyiség mélyebb megismerését. 


\section{AZ EMPIRIKUS KUTATÁS RELEVANCIÁJA, CÉLJA ÉS HIPOTÉZISEI}

Az irodalmi áttekintésből látható, hogy a rendszeres fizikai aktivitás számtalan elönnyel járhat az egyén fizikai és mentális egészségére. A pozitív hatások miatt fontos, hogy minél többen sportoljanak. A motiváció és az egészségpszichológia kapcsolatának minél mélyebb megismerése elengedhetetlen, amely talán segítheti a társadalmat sújtó inaktivitás leküzdését.

Az empirikus kutatásom kérdéseit és hipotéziseit $(\mathrm{H})$ több kérdéskörre építettem, így kíváncsi voltam a serdülők sport iránti elköteleződésének szociodemográfiai tényezöire és sportolási szokásokkal kapcsolatos tulajdonságaira, a sport-elköteleződés modell kapcsolatára más motivációs elméletetekkel. Vizsgáltam a sport iránti elköteleződés kapcsolatát az egészségpszichológiával, továbbá a sportélvezet hatásait is a serdülőkre, hiszen a kutatások szerint a sport szeretete a legfontosabb forrása a sport-elköteleződés modellnek.

I. A sport-elköteleződés kutatásához kapcsolódó mérőeszközök adaptációja

a. Hogyan használhatóak a magyar változatú sport-elköteleződés-2, sportélvezet és sportolói identitás kérdőívek magyar mintán?

II. A sport-elköteleződés modell összefüggései szociodemográfiai tényezőkkel és sportolási szokásokkal.

a. Milyen szociodemográfiai adatok (pl.: nem, kor stb.) és sportolási szokások (pl.: versenyzés szintje, sportág, egyéni/csapatsport stb.) befolyásolják a serdülők sport iránti elköteleződését?

III. Egyéb sportmotivációs megközelítések és összefüggései a sport-elköteleződés modellel.

a. A sport elköteleződés típusai és forrásai, hol helyezkednek el az öndeterminációs kontinuumban?

b. A sport-elköteleződés modellnek milyen kapcsolata van a sportolói identitással?

IV. A sport-elköteleződés modell összefüggései és kapcsolatai az egészségpszichológiával. 
a. Milyen összefüggés tapasztalható a sport iránti elköteleződés forrásai és típusai között?

b. Milyen összefüggés tapasztalható a sport iránti elköteleződés és a különböző egészségpszichológia (szubjektív jólét, aspirációk, jövőorientáció, perfekcionizmus, egészségattitüd) változók között.

V. A sportélvezet jellemzői és összefüggései az egészségmagatartással.

a. Hogyan jellemezhető a sportélvezet?

b. Milyen összefüggés tapasztalható a sportélvezet és a jövőorientáció, az aspirációk és az élettel való elégedettség között?

A feltett kérdésekhez a következő hipotéziseket fogalmaztam meg:

I. A sport-elköteleződés kutatásához kapcsolódó mérőeszközök.

H1: Feltételezem, hogy a magyarra fordított és adaptált skálák (sport-elköteleződés kérdőív-2, sportélvezet, sportolói identitás) megfelelő megbízhatósággal és faktorszerkezettel rendelkeznek.

II. A sport-elköteleződés modell összefüggései szociodemográfiai tényezőkkel és sportolási szokásokkal.

H2: Feltételezem, hogy a kor, a nem, az anyagi helyzet, a sportág, a sportolás szintje, a sportolás ideje, az edzés mennyisége, az egyéni/csapatsport jellege befolyásolják a sport-elköteleződés modell változóit.

III. Egyéb sportmotivációs megközelítések és összefüggései a sport-elköteleződés modellel.

H3: Feltételezem, hogy a lelkes elköteleződés magas, míg az erőltetett elköteleződés alacsony öndeterminációval áll kapcsolatban.

H4: Feltételezem, hogy az alacsonyabb öndetermináció inkább a közöségi jellegü, befektetések, valamint az alternatívákat leíró változókkal állhatnak kapcsolatban (pl.: közösségi kényszer), míg a magasabb öndeterminációra az egyéni jellegü és a teljesítményt leíró (pl.: sportélvezet, törekvés a fejlödés - képesség) változók jellemzőek. 
H5: Feltételezem, hogy a sport iránti elköteleződés közösségi szintủ változói, valamint a lelkes elköteleződés, a sportélvezet, a sportban rejlő lehetőségek, befektetések, az egyéni törekvések a fejlődésre, pozitív hatással lehetnek a sportolói identitásra.

H6: Feltételezem, hogy az erőltetett elköteleződést negatívan befolyásolja a sportolói identitást

VI. A sport-elköteleződés modell összefüggései és kapcsolata az egészségpszichológiával.

H7: Feltételezem, hogy a sportélvezet, értékes lehetőségek, és a törekvés a fejlődésre - képesség, személyes befektetések - mennyiség változóknak pozitív, kapcsolata van a lelkes elköteleződéssel.

H8: Feltételezem, hogy az egyéb prioritások, személyes befektetések - veszteség és a közösségi kényszer változóknak pozitív, kapcsolata van az eröltetett elköteleződéssel.

H9: Feltételezem, hogy a magasabb szubjektív jóllét, intrinzik aspiráció, jövőorientáció és az egészségattitűd skálák értékei a lelkes elköteleződéssel állnak kapcsolatban, míg az alacsonyabb értékei, és az extrinzik aspiráció az erőltetett elköteleződésre hatnak.

H10: Feltételezem, hogy a perfekcionizmus alskálái közül az összeszedettség és a személyes elvárások a lelkes elköteleződéssel, míg a szülői elvárások, szülői kritika, viselkedés miatti kételyek és a hibák miatti aggodalom az erőltetett elköteleződéssel állnak kapcsolatban.

V. A sportélvezet összefüggései az egészségmagatartással.

H11: Feltételezem, hogy a saját kompetencia a sportélvezet legfőbb forrása.

H12: Feltételezem, hogy a sportélvezet modell intrinzik jellegü forrásai az élettel való elégedettséggel, a jövőorientációval és a intrinzik aspirációkkal mutatnak kapcsolatot, míg a extrinzik jellegü források az extrinzik aspirációkkal állnak kapcsolatban. 


\section{AZ EMPIRKUS KUTATÁS MÓDSZEREI}

A kutatásomban két egymástól független vizsgálat történt. Az első mintavétel 2017 tavaszán a második pedig 2018 őszén történt 526, valamint 344 fő részvételével. A fejezetben a két vizsgálatot kronológiai sorrendben ismertettem.

\subsection{Az első vizsgálat}

\subsubsection{Az adatfelvétel folyamata}

Az első adatfelvételem 2017 tavaszán valósult meg, Az adatfelvételnél arra törekedtem, hogy a lehető legtöbb serdülő sportolót megszólítsam, így olyan ún. köznevelési típusú sportiskolákat kerestem fel, melyeket a Magy Olimpiai Bizottság támogatását is élvezik. A mintavétel alkalmával összesen több, mint tíz budapesti iskolát kerestem meg, melyek közül öt vállalta, hogy részt vesz a kutatásomban. A mintába olyan tanulók kerültek, akik rendszeresen sportoltak legalább hobbi szinten, de sokak valamilyen válogatottnak is a tagjai voltak.

Az adatfelvétel előtt, az intézményi etikai engedély megszerzését követően tájékoztattam a résztvevő iskolák vezetését, tanárait, diákjait, valamint a kutatásban résztvevő diákok szüleit. Biztosítottam őket, hogy semmilyen személyes adatot nem gyüjtök, és válaszaikat kizárólag statisztikai adatelemzésre használom fel. A papír alapú kérdőíveket a tanulók testnevelés órai keretek között töltötték ki a testnevelö tanárok felügyelet mellett. A kérdőív kitöltése kb. 25-30 percet vett igénybe.

\subsubsection{A minta jellemzői}

Az első vizsgálatom 526 serdülő sportolóval $(M=16,41 ; S D=1,21)$ készült. A kitöltők 38 különböző sportág képviselői voltak és átlagban 8,2 éve sportoltak. A csapat (n=267) és az egyéni (n=259) sportolók közel egyenlően szerepeltek a vizsgálatban. A mintában a nemek a következőképpen oszlottak meg: 275 fiú (52,3\%), 251 lány (47,7\%). A felmért diákok csaknem kétharmada (66\%) sporttagozatos osztályban tanult, míg a kisebbik része (34\%) hagyományos gimnáziumi osztályban. A kérdőíves vizsgálatban felmértem a serdülők sportolási szintjét is, majd a válaszokból később négy összevont kategóriát alakítottam ki a jobb összehasonlíthatóság kedvéért. Így az első csoportba a nemzetközi és válogatott szinten versenyző sportolók kerültek, akik a minta 39,7\%-át (n=209) tették ki. Az országos bajnokságokon indulók alkották a második csoportot, ők a minta 34,4\%-át $(n=180)$ alkották. A megyei vagy helyi versenyeken a sportolók 
9,1\%-kal ( $\mathrm{n}=48)$ voltak képviselve. Az utolsó összevont csoportba azok a sportolók kerültek, akik nem versenyeznek (de lehet, hogy később fognak) vagy hobbi szinten sportolnak, és ők a minta 16,5 \%-át $(\mathrm{n}=87)$ tették ki. A teljes mintából két sportoló nem adott választ erre a kérdésre. A mintában szereplő résztvevők 43\%-a (n=226) négy csapatsportág képviselői. Ezek a labdarúgás $(n=81)$, kosárlabda $(n=33)$, kézilabda $(n=42)$ és vízilabda $(n=70)$. A mintában szereplő serdülők 45,6 százaléka heti ötnél többször vesz részt edzéseken, 46,9 százalékának 45 edzése van hetente, 23,2 százaléka pedig 2-3 edzésen vesz részt minden héten. A minta 4,2 százaléka mondta, hogy heti 1 edzésen vesz csak részt.

A mintában szereplők szociodemográfiai hátterét tekintve elmondható, hogy leginkább a középosztályt $(\mathrm{n}=295)$ és a felső középosztályt $(\mathrm{n}=176)$ képviselik. A megkérdezettek több mint fele családi házban $(51,1 \%)$, míg kisebb része lakótelepi és társas házban él $(39,3)$. Bérlakásban és kollégiumban a minta elenyésző hányada él. A megkérdezett serülők 62,5 százaléka rendezett családi körülmények között, azaz mindkét szülővel él együtt. A vegyes családból (vérszerinti szülö és nevelőszülö) származó serdülök a mintánk mindössze 9,7 százalékát tették ki. Az adatfelvételemből az is kiderül, hogy a szülők többsége szellemi munkát végez és nagyobb részük diplomával rendelkezik.

\subsubsection{Mérőeszközök}

\section{Szociodemográfiai adatok}

Az összeállított kérdőívcsomagok első részét a tanulók hátteréről szóló kérdések adták. Így adatokat gyüjtöttem a tanulók neméről, életkoráról, iskolai státuszáról és családi hátteréről (pl.: anya-apa iskolai végzettsége, beosztása; lakhely; stb.). Megkérdeztem továbbá a tanulókat arról is, hogy milyen társadalmi rétegbe sorolják magukat.

\section{Sportolási szokások}

A tanulók sportolási szokásai központi szerepet játszottak a kutatásban, így megkérdeztem, hogy mit és milyen szinten sportolnak. Valamint kíváncsi voltam, hogy heti hány edzésen vesznek részt és mennyi órát töltenek sportágukkal. 


\section{Sport-elkötelezödés kérdőiv-2}

A kutatásomban a sport iránti elköteleződést a Scanlan és mtsai (2016) által kidolgozott ún. „Sport-elköteleződés kérdőív 2" magyarra fordított és adaptált változatával mértem. A skála összesen 58 tételt és 12 alskálát tartalmazott, ahol a válaszadóknak egy 5 fokú Likert (1=egyáltalán nem értek egyet; 5=teljes mértékben egyetértek) típusú skálán kellett válaszolniuk a feltett kérdésekre. A 12 alskála méri a kétféle elköteleződés típust és annak tíz feltételezett forrását. Az elköteleződés típusai: lelkes elköteleződés és erőltetett elköteleződés. A források pedig a következők: sportélvezet; értékes lehetőségek; egyéb prioritások; személyes befektetések-mennyiség; személyes befektetések-veszteség; közösségi kényszer; közösségi támogatás-érzelmi; közösségi támogatás-informális; törekvés a fejlődésre-képesség; törekvés a fejlődésre-közösség. Az alskálák megbízhatósági mutatói 0,66 és 0,91 között ingadoztak, míg ezek az értékek az eredeti tanulmányban 0,71 és 0,92 között találhatók (Scanlan és mtsai, 2016). A skála fordítása és adaptálása kutatásaimban valósult meg, melyet a későbbiekben részletesen ismertettek.

\section{Sportélvezet skála}

A sportélvezet forrásait Wiersma (2001) Source of Enjoyment in Youth Sport Questionnaire skálájának magyarra fordított és adaptált változatával mértem, melynek folyamatát a későbbiekben szintén részletezek. A skála 28 kérdést tartalmazott, amelyekre ötfokú Likertskálán kellett válaszolniuk a megkérdezetteknek (1=egyáltalán nem jellemző rám; 5= erősen jellemző rám). Wiersma a 28 kérdést hat különböző alskálára osztotta, melyek a következők: saját kompetencia, versenyzés izgalma, erőfeszítés jutalma, csapatszellem, szülői támogatás, másokhoz viszonyított kompetencia. Wiersma (2001) ezeket az alskálákat dimenziókba rendezte. Így létrehozott extrinzik (másokhoz viszonyított kompetencia, csapatszellem, szülői támogatás) és intrinzik (saját kompetencia, versenyzés izgalma, erőfeszítés jutalma), valamint teljesítménnyel összefüggő (saját kompetencia, másokhoz viszonyított kompetencia) és teljesítménytől független (versenyzés izgalma, erőfeszítés jutalma, csapatszellem, szülői támogatás) sportélvezet kategóriákat. A skála megbízhatósági értékei következők voltak: Cronbach alpha $=0,71-0,94$ (eredeti tanulmányban 0,65-0,85; Wiersma, 2001) 


\section{Élettel való elégedettség skála}

Az élettel való elégedettség mérésére a szubjektív jóllétet jellemző globális skála (The Satisfaction With Life Scale, SWLS; Diener és mtsai, 1985), hazai, validált verzióját (Martos és mtsai, 2014) alkalmaztam, amely 5 itemből áll. A skála az élettel való általános elégedettséget mérte, olyan állításokkal, mint például: „Elégedett vagyok az életemmel”. A válaszkategóriák nullától (egyáltalán nem értek egyet) hétig (teljesen egyetértek) terjedtek. A skála megbízhatóságát mérő Cronbach alpha értéke a saját mintában 0,87 volt, de az eredeti tanulmányban is hasonló értékeket kaptak $(0,88)$.

\section{Aspirációs Index}

Az ún. Aspirációs Index az extrinzik (hírnév, gazdagság, külső megjelenés) és intrinzik (tartalmas emberi kapcsolatok, személyes fejlődés, társadalmi elköteleződés) hosszú távú célokat vizsgálja (Kasser és Ryan, 1996; V. Komlósi és mtsai, 2006). A 14-tételes rövidített változatát Martos és mtsai (2006) dolgozták ki, amelyben az egyes célokhoz (összesen hét, ebből négy intrinzik és három extrinzik) két-két állítás tartozott. A Likert- skála kérdései arra kerestek választ, hogy mennyire fontos a megkérdezettnek az adott cél megvalósítása a jövőben. A válaszkategóriák egytől (egyáltalán nem fontos) ötig (rendkívül fontos) terjedtek. A megbízhatóságot mérő Cronbach alpha értékei a saját mintával a következők voltak: 0,82 (extrinzik célok) és 0,71 (intrinzik célok).

\section{Jövőorientációs skála}

A jövőorientáltság mérésére alkalmazott skála, The Consideration of Future Consequences Scale (Short Version) hat elemböl állt (Strathman és mtsai, 1994). A skála elemei olyan állításokat tartalmaztak, mint például: „Hajlandó vagyok pillanatnyi boldogságomat vagy kényelmemet feláldozni jövőbeli célok elérése érdekében”. A válaszkategóriák 1-től 5-ig terjedtek. A végső skála 6 és 30 pont közötti értékeket ért el, a Cronbach alpha értéke 0,55 volt, hasonlóan egy korábbi, serdülökön végzett hazai vizsgálathoz (Pikó, 2007). 


\subsection{A második vizsgálat \\ 4.2.1. Az adatfelvétel folyamata}

A második adatfelvételem 2018 őszén történt és nagyban hasonlított az első vizsgálatban leírtakhoz. Hasonlóképpen az előzőekhez a köznevelési típusú sportiskolákat kerestem meg. A megkeresett iskolák közül végül három mondott igent a második vizsgálatomra, így a mintába két budapesti és egy vidéki sportiskola diákjai kerültek. Az előzőekhez hasonlóan a tanulók papír alapú kérdőíveket kaptak, melyeket a tanulók testnevelés óra keretei között töltöttek ki. Természetesen az adatfelvétel előtt tájékoztattam a résztvevő iskolák vezetését, tanárait, diákjait, valamint a kutatásban résztvevő diákok szüleit. Biztosítottam őket, hogy semmilyen személyes adatot nem gyűjtök, és válaszaikat kizárólag statisztikai adatelemzésre használom fel. A második vizsgálatnál használt kéröívcsomag kitöltése kb. 25-30 percet vett igénybe.

\subsubsection{A minta jellemzői}

A második adatfelvételben 344 középiskolás sportoló (fiú = 131, leány = 213) vett részt, akiknek átlagéletkoruk 16,57 életév (szórás = 1,67) volt. A második vizsgálatban részt vett serdülő sportolók több mint 80,9\%-a $(\mathrm{n}=280)$ sporttagozatos osztályba járt, míg 19,1\% (n=64) a nem sporttagozatos osztályokat képviselte. A mintánkban szereplő sportolók átlagban 7,98 éve (szórás $=3,76$ ) sportolnak, és valamivel több, mint 5 éve versenyeznek is. A serdülő sportolók hetente átlagban 9,12 órát (szórás = 5,82) töltenek edzéssel. A résztvevők különböző sportolási szinteket képviselnek: válogatott szinten a résztvevők 16,5\%-a $(\mathrm{n}=58)$ versenyez; országos versenyeken a mintánk csaknem fele, azaz 45,7\%-a $(n=158)$ vesz részt. Helyi szintű versenyzőket a kutatásban részvevők 16,6\%-a (n=61) képviseli. A hobbi szintü versenyzőket a minta 19,4\%-a (n=67) teszi ki. Kutatásomban összesen 30 sportág képviselői vettek részt. Az egyéni $(\mathrm{n}=183)$ és a csapat $(\mathrm{n}=161)$ sportágak közel azonos arányban oszlanak meg. Budavári (2007) sportági csoportosítását használva megállapítható, hogy mintánk több, mint fele a taktikai sportágakból került ki ( $n=176$; pl.: labdajátékok, tenisz) és 24,0\%-a valamilyen állóképességi sportágat üz (n=83; pl.: úszás, atlétika). A müvészeti sportágak képviselői mintánk 18,2\%-át adják ( $\mathrm{n}=63$; pl.: torna, tánc), és a résztvevők 5,2\%-a valamilyen küzdősportág versenyzője ( $\mathrm{n}=18$; pl.: karate, judo).

A második mintában szereplők szociodemográfiai háttere nagyban hasonlít az első vizsgálat összetételéhez. A diákok mintegy 62,1 százaléka két szülővel él együtt és 19,3 
százalék azok aránya, akik csak az egyik szülővel élnek. A vegyes családból származó gyerekek a minta 11,3 százalékát tették ki. Csakúgy, mint az első felmérésemnél a minta több mint fele (56,4\%) családiházban él és 40,5 százaléka lakik bérházban vagy lakótelepi lakásban. A szülők közül legtöbben egyetemet vagy föiskolát végeztek (anyák $=55 \%$; apák $=49 \%$ ), a csak érettségivel rendelkezők aránya is magas (anyák $=35 \%$; apák $=31 \%$ ). A szülők munkahelyére jellemző, hogy az édesapák közül legtöbben vállalkozók, míg az édesanyák inkább szellemi munkát végeznek. A második adatfelvételnél is megkérdeztem a tanulókat, hogy milyen társadalmi rétegbe sorolják magukat. Csakúgy, mint az előző adatfelvételnél itt is legtöbben a középosztály $(52,6 \%)$ és a felső középosztályba $(39,0 \%)$ sorolták magukat.

\subsubsection{Mérőeszközök}

Az első vizsgálattal összhangban készült kutatásom több, már az előzőekben használt skálát is

tartalmazott. Így felhasználásra került a szociodemográfiai és sportolási szokásokra vonatkozó kérdőív. Ezeken kívül a következő mérőeszközöket vontam be a második vizsgálatba:

\section{Sport-elkötelezödés kérdőiv-2}

A kérdőív megegyezett az első vizsgálatunkban használt kérdőívvel. A második vizsgáltban a megbízhatósági értékek eltértek. Ezek a következők voltak: Cronbach alpha =0,65-0,91.

\section{Sportmotivációs Skála}

A sportolói motivációt a Sportmotivációs skála javított verziójával (SMS-II; Pelletier, Rocchi, Vallerand, Deci és Ryan, 2013) végeztem, melyet Paic és munkatársai (2017) fordítottak és adaptáltak a magyar viszonyokhoz. A kérdőív 19 tételt és 6 alskálát tartalmazott, ahol a válaszadóknak egy hétfokú Likert típusú skálán kellet a válaszokat megadniuk (1=egyáltalán nem értek egyet; 7=teljes mértékben egyetértek). A kérdőívet úgy alkották meg, hogy vizsgálja a Deci és Ryan (2000) féle öndeterminációs elmélet elemeit (amotiváció, külső szabályozás, introjektált szabályozás, identifikált szabályozás, integrált szabályozás, belső motiváció), így az alskálák is ezekhez igazodnak. Adaptációs vizsgálat Cronbach alpha értékei 0,80 és 0,90 között mozogtak (Paic és mtsai, 2017), míg az én kutatásomban ezek az értékek 0,66 és 0,91 között helyezkednek el. 


\section{Multidimenzionális Perfekcionizmus Skála}

A perfekcionizmust a Frost Multidimenzionális Perfekcionizmus Skála segítségével mértem (Frost és mtsai, 1990). A 35 tételt tartalmazó skála magyar nyelvü fordítását használtam fel (Dobos és Pikó, 2017). A skála a perfekcionizmus hat dimenzióját méri egy 5-fokozatú Likertskálán ( 1 = egyáltalán nem jellemzö rám; 5 = nagyon jellemző rám). Az alskálák a következők: hibák miatti aggodalom, személyes elvárások; szülöi elvárások; szülői kritika; viselkedés miatti kételyek és összeszedettség. A megbízhatóságot jelző A mintán a Cronbach alpha értékek 0,68 és 0,92 között volt. Korábbi hazai mintán ezek az értékek 0,75 és 0,92 között változtak (Dobos és Pikó, 2018), míg Frost tanulmányában 0,77 és 0,93 közöttiek voltak (Frost és mtsai, 1990).

\section{Sportolói identitás skála}

A sportolói identitást az ún. Sportolói Identitás skála magyar változatával mértem (Brewer és mtsai, 1993). A fordítást és az adaptációt magam végeztem egy előző kutatásomban, melyet a későbbiekben igyekszem bemutatni. A skála 10 itemet tartalmazott, és a válaszokat egy 7 pontos Likert-típusú skálán lehetett megadni (1= egyáltalán nem értek egyet; $7=$ teljes mértékben egyetértek). A skála összpontszáma megadta az ún. Sportolói Identitás Indexet (7-70). Az index átlagértéke a mintánkon 47,20 volt. A skála megbízhatóságát vizsgáló Cronbach-alpha az egész mintán 0,95-es, azaz kiváló értéket mutatott (az eredeti tanulmányban: 0,92; Brewer és mtsai, 1993). Az alminták megbízhatósága a fiúknál 0,80, míg a lányoknál 0,94 volt.

A két adatfelvétel során használt mérőeszközök megbízhatósági értékét a könnyebb érthetőség kedvéért egy külön táblázatban is összefoglaltam (2. táblázat).

\section{2. táblázat. A kutatásban használt mérőeszközök Cronbach alpha értékei.}

1. adatfelvétel 2. adatfelvétel

\begin{tabular}{lcc}
\hline Sport elkötelezödés kérödív-2 & $0,66-0,91$ & $0,65-0,91$ \\
Sportélvezet skála & $0,71-0,94$ & - \\
Élettel való elégedettség & 0,87 & - \\
Aspirációs index & $0,71-0,82$ & - \\
Jövőorientációs skála & 0,55 & - \\
Sportmotivációs skála & - & $0,66-0,91$ \\
Multidimenzionális perfekcionizmus skála & - & $0,68-0,92$ \\
Sportolói identitás skála & - & 0,95 \\
\hline
\end{tabular}


A megbízhatósági értékek elfogadásában Cronbach (1951) ajánlását követtem. Szerinte 0,70 felett fogadható el egy skála megbízhatósága, ugyanakkor Pallant (2010) rávilágított arra, hogy a Cronbach alpha érzékeny az item számra, így az alacsonyabb érték is elfogadható. Számos olyan tanulmány olvasható a nemzetközi szakirodalomban, ahol már a 0,60 fölötti értéket is elfogadhatónak tekintik (pl.: Griethuijsen és mtsai, 2014) 


\section{AZ EMIPIRKUS KUTATÁS EREDMÉNYEI}

Az eredményeim ismertetését összesen öt nagyobb tematikus egységre tagoltam. Az elsőben célom bemutatni azokat az adaptált mérőeszközöket, melyek kutatásom középpontjában állnak és még nem rendelkeztek magyar változattal. A második részben a sport-elköteleződés kerül elötérbe, ahol szociodemográfiai adatok és sportolási szokások mentén vizsgálom a modell különbségeit és kapcsolatait. A harmadik részben az a célom, hogy az olvasó el tudja helyezni más motivációs elméletek között a sport-elköteleződés modellt, így bemutatom összefüggéseit az öndeterminációs elmélettel, valamint a sportolói identitás elméletével. A negyedik részben a mentális egészség játssza a főszerepet, így ebben a részben mélyebben megvizsgálom a modellt, valamint kapcsolatát egészségpszichológiai változókkal. Végezetül megvizsgálom a sportélvezetet, mely a szakirodalom alapján az elköteleződés egyik legfontosabb forrása.

\subsection{Adaptációs vizsgálatok}

Az alfejezetben az empirikus kutatás első kérdéskörével foglalkozom. Vizsgálataimban három olyan mérőeszközt használtam (Sport Elköteleződés Kérdőív-2, Sportélvezet Skála, Sportolói Identitás Skála), amely eddig magyar verzióval nem rendelkezett, ezért ezeket a mérőeszközöket kutatásomban adaptáltam a hazai viszonyokhoz. Az adaptálási folyamat mind a három kérdőívnél hasonló lépések mentén történt. Először angolul és magyarul is jól beszélő szakemberek bevonásával a fordítást végeztem el majd ezt követte a kiscsoportos tesztelés, hogy megbizonyosodhassak a kérdőívek használhatóságáról. Második lépésként a nagymintás adatfelvétel történt. Az adaptálás utolsó lépéseként - hogy megbizonyosodjak a konstrukciós érvényességről, valamint a megbízhatóságról - statisztikai adatelemzésnek vettetem alá az adataimat. Fontos megjegyezni, hogy a skálák fordítási adaptációs folyamatának módszertana megegyezett, de azok eltérő években készülttek el.

A skálák fordítása mind a három esetben hasonlóképpen történt, követve Banville, Desrosiers és Genet-Volet (2000) ajánlását. A skálát elöször két, az angol és a magyar nyelvben jártas kolléga lefordította, majd ezeket a magyar változatokat egyeztetve egy harmadik, független személy visszafordította az eredeti nyelvre. Második lépésként a pszichológiában és a sportban jártas szakemberek megvizsgálták a tételeket és megállapították, hogy a fordítások megfelelőek voltak, így a kérdőívek tartalmi validitását elfogadottnak tekintettem mind a három esetben. Végezetül mind a három skála kipróbálásra került 
(különböző időpontokban) éles helyzetben, ahol a kitöltő serdülő diákokat arra kértem, hogy jelezzék nyelvtani, fogalmi és érthetőséggel kapcsolatos aggályaikat. Ezzel az utolsó lépéssel megbizonyosodhattam, hogy a fordított skálák, érthetőek és jól használhatóak a serdülő sportolók körében. A következőkben a három skála adaptációs folyamatának statisztikai elemzését mutatom be, melyekben igyekszem megválaszolni elözetesen feltett hipotézisemet is $\left(\mathrm{H}_{1}\right)$.

\subsubsection{A sport-elköteleződés kérdőív-2 adaptációs vizsgálata}

Az adaptációs vizsgálat az első felmérésből származó sport-elköteleződés-2 kérdőívre adott válaszok elemzésével valósult meg $(\mathrm{n}=526)$.

\subsubsection{Statisztikai módszer}

Az adatainkat SPSS 22.0 és AMOS 20.0 programokkal elemeztem. Az alap statisztikai mutatók mellet feltáró, valamint megerősítő faktoranalízist használtam a kérdőív érvényességét vizsgálva. Bearden és munkatársainak (2011) ajánlása szerint az adatokat véletlenszerủen két részre osztottam, 40-60 százalékos arányban a feltáró $(n=201)$ és a megerősítő faktoranalízis $(\mathrm{n}=325)$ számára. Azért döntöttem a nem egyenlő felosztás mellett, mert a megerősítő faktorelemzés az item szám és a faktor szám miatt nagyobb mintát igényel. A szakirodalomban gyakori módszer a hasonló kettéosztás olyan adaptációs vizsgálatoknál, ahol viszonylag alacsony elemszám áll rendelkezésre a két elemzés elvégzéséhez (Kyriazos, 2018; Walker és Howe, 2017; Wong, Mak és To, 2015)

Kutatásomban elöször feltáró faktoranalízissel (EFA) feltártam (n=201) a kérdőív faktor struktúráját, melyhez az ún. főkomponens-elemzést alkalmaztam varimax rotációval. Az ezt követő megerősítő faktoranalízis (CFA) segített a minta másik felén ( $n=325)$ ellenőrizni a faktorok stabilitását és szerkezetét. Az eredményeim értelmezésére több, napjainkban is gyakran alkalmazott fittségi mutatót használtam fel. Ezek a következők voltak: khi négyzet $(\chi 2)$, a khi négyzet valamint a szabadságfok hányadosából adódó érték (CMIN/d.f); root mean square error of approximation (RMSEA); a Tucker-Lewis index (TLI); comparative fit index (CFI); standardized root mean square residual (SRMR). A fittségi mutatók elfogadható értékeiről követtem a szakirodalom ajánlásait. Ezek szerint a khi négyzet ( $\chi 2)$ akkor fogadható el, ha nem szignifikáns értéket mutat, azonban, a khi négyzet érzékeny az elemszámra, így a kutatók azt 
javasolják, hogy a relatív khi négyzet értékét vizsgáljuk. Ez az érték a khi négyzet és a szabadságfok által létrejött hányados (CMIN/d.f), melynek értéke akkor elfogadható, ha 5 alatt van (Byrne, 2010; Hu és Bentler, 1999), de 3 alatt az értéke kiváló (Garson, 2015). Az RMSEA értéke független a mintától és 0,08 alatti értéknél elfogadhatónak mondhatjuk (Byrne, 2010; Hooper, Coughlan, és Mullen, 2008). A Tucker-Lewis index szintén független a minta nagyságától. Az értéke mindig 0 és 1 közé esik, és akkor mutat jó illeszkedést, ha 0,90 fölé esik (Hu és Bentler, 1999). Az összehasonlító illeszkedési mutató (CFI) az adatok és a hipotetikus modell közötti különbséget vizsgálja. Megmutatja, hogy a modell, a null modell és a tökéletesen illeszkedő modell között milyen illeszkedés található. Az értéke szintén 0 és 1 közé esik és csak úgy, mint az előzőekben 0,90 fölött mutat jó illeszkedést, de minél magasabb az értéke, annál jobb a modell illeszkedése. Az SRMR értéke a minta és a modell kovariancia mátrixa közötti eltérést mutatja. Ha az érték kisebb, mint 0,08 akkor elfogadható illeszkedésröl beszélünk (Bryant és Satorra 2012).

Megvizsgáltam a kérdőív megbízhatósági mutatóit is. Ehhez az ún. átlagos magyarázott variancia értékét (Avarage Variance Explained; AVE), az indikátorhoz tartozó fogalmi megbízhatósági mutatót (Composite Reliablitity; CR), valamint a széles körben ismert Cronbach alphát használtam. A három különbözö mutatót a jobb megbízhatóság és a szakirodalomi összehasonlíthatóság érdekében választottam. A Cronbach alpha és CR értéke 0,70-töl fogadható el (Hair, Black, Babin és Anderson, 2009), míg az AVE tekintetében több esetet is említ a szakirodalom. Általánosságban 0,50-ös értéktől válik elfogadhatóvá, de találkozhatunk esetekkel, ahol a kutatók elfogadhatónak tekintik az alacsonyabb értékeket, ha a fogalmi megbízhatósági mutató 0,60 fölött található (Malhotra és Dash, 2011; Huang, Wang, Wu és Wang, 2013).

\subsubsection{Eredmények}

\section{Feltáró faktoranalízis}

A sport elköteleződés kérdőív-2 faktor szerkezetének megismeréséhez, az ún. feltáró faktoranalízist (EFA) használtam az első almintán (n=201). A szakirodalommal összhangban külön elemzéseket végeztem az elkötelezödés típusai és az elköteleződés forrásai között (Gabriele, Gill és Adams, 2011; Scanlan és mtsai, 2016; Wilson és mtsai, 2004). 
A főkomponens elemzéssel és varimax rotációval végzett feltáró faktoranalízis kétféle elköteleződés típust tárt fel, mely megegyezik a szakirodalomban leírtakkal. A magyarázott variancia értéke 55,86 százalék volt, míg a Kaiser-Mayer-Olkin index 0,86-ot mutatott. Az első faktor hat elemet foglalt magába, melyek olyan kérdéseket tartalmaztak, amik az önkéntes sport részvételre serkentik a sportolót (pl.: Szinte bármire képes vagyok, hogy folytassam ezt a sportot.), így ez a faktor a lelkes elköteleződés nevet kapta. A második faktor öt kérdést tartalmazott és a sport folytatására vonatkozó kötelezettségeket írta le (pl.: Úgy érzem, hogy kényszerítve vagyok, hogy folytassam ezt a sportot.), így a második faktor neve eröltetett elkötelezödés lett.

Az elköteleződés típusok után megvizsgáltam a sport-elköteleződés forrásainak faktorszerkezetét is, melyet az előzőekhez hasonlóan elemeztem. A Kaiser-Mayer-Olkin index 0,80, míg a magyarázott variancia értéke 66,1 százalék volt és összesen 10 faktort kaptam, mely megegyezik a szakirodalomban leírtakkal (Scanlan és mtsai, 2016). Az első faktor a sportélvezet nevet kapta és öt itemet tartalmazott, melyek a sportszeretetre irányultak (pl.: Imádom ezt a sportot üzni.). A második faktor öt tételből állt és az egyén fejlődése állt a középpontjában (pl.: Arra törekszem, hogy minden lehetőséget kihozzak magamból ebben a sportban.), így a faktor elnevezése törekvés a fejlödésre - képesség lett. A harmadik faktor a személyes befektetések - veszteség nevet kapta, mivel a négy tétel azokat az erőfeszítéseket vizsgálja, melyet elveszíthet a sportoló, ha abbahagyja a sportolást (pl.: A fizikai erőfeszítés, amit ebbe a sportba fektettek, megnehezíti, hogy abbahagyjam.). A következő faktor öt tételt tartalmazott és azokat a kérdéseket foglalták magukba, melyek a befektetett energia mennyiségével foglalkoznak (pl.: Nagyon sok fizikai erőfeszítést fektettem a sportba), így a faktor neve személyes befektetések - mennyiség lett. Az ötödik faktornak a törekvés a fejlödésre - közösség nevet adtam, mely négy tételt tartalmazott és olyan állítások fogalmazódnak meg benne, amelyek az ellenfelek legyőzésére irányulnak (pl.: Igyekszem mindig jobbnak lenni az ellenfélnél ebben a sportban.). A közösségi kényszer lett a hatodik faktor. Négy itemet tartalmazott és a mások általi megfeleléssel kapcsolatos állítások találhatóak meg benne (pl.: A számomra fontos személyek csalódottak lennének, ha abbahagynám ezt a sportot.). A következő faktornak az egyéb prioritások nevet adtam, hiszen azt vizsgálta, hogy milyen egyéb alternatívák vannak a sportolók életében (pl.: Majdnem lehetetlen sportolni az életem egyéb dolgai miatt.). A nyolcadik faktor négy tételt tartalmazott és barátoktól érkező támogatásokra 
(pl.: A számomra fontos személyek a főbb sport versenyeimen részt vesznek) kérdezett rá, így a faktor a közösségi támogatás - érzelmi elnevezést kapta. A kilencedik faktor négy itemet tartalmazott és az értékes lehetőségek nevet kapta. Olyan állításokat foglal magába, melyek a sportolóra nézve lehetőségeket írnak le (pl.: Vannak olyan jövőbeli versenyek/események, melyek hiányoznának, ha abbahagynám ezt a sportot.). Az utolsó faktor neve közösségi támogatás - informális lett, mely három itemet tartalmazott és az edzőktől jövő támogatásokat vizsgálja (pl.: Van mentorom, aki segítséget nyújt a sportpályafutásomban.).

Az elemzés során statisztikai okokból (alacsony faktorsúly) hat itemet töröltem a további elemzésekből. Úgy látom, hogy a kapott faktorok megegyeznek a szakirodalomban leírtakkal és lefedik a sport-elköteleződés modell valamennyi elemét is, igaz azok szerkezete eltér Scanlan és munkatársainak (2016) kérdőívétől.

\section{Megerösitö faktoranalizis}

Megerősítő faktorelemzést (CFA) használtam, hogy megbizonyosodjak a kapott struktúra megbízhatóságáról és érvényességéről. Az elemzést a minta második csoportjából származó adatok felhasználásával készítettem $(n=326)$. Hasonlóan a feltáró faktoranalízishez külön elemzés készült az elköteleződés típusok és források között (pl.: Wilson és mtsai, 2004).

Az első elemzés során a kétféle elköteleződés típust (10. ábra) vizsgáltam, melyek tökéletes illeszkedést mutattak a mintával (CMIN/d.f. = 2,23 $\left(\mathrm{X}_{2}(41)=91,37\right)$ CFI = 0,96, TLI $=0,95, \mathrm{RMSEA}=0,06 \mathrm{SRMR}=0,07)$.

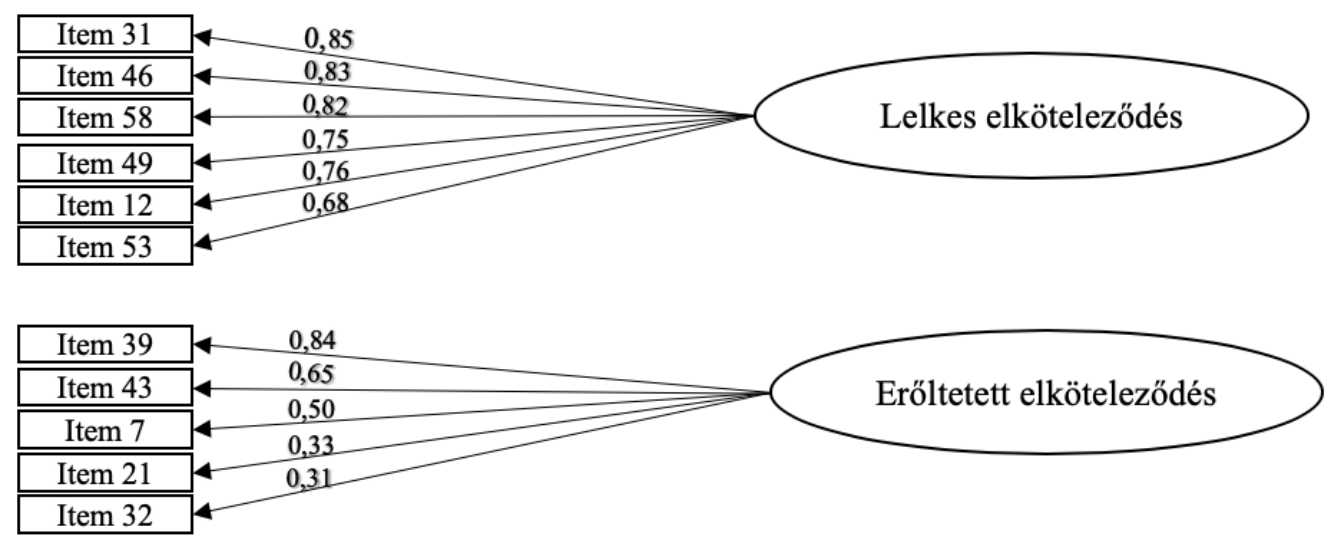

10. ábra. Elkötelezödés típusok faktor szerkezete és faktorsúlya a CFA elemzés szerint

A második elemzés során az elköteleződés forrásait elemeztem, melyhez felállítottam a 10 faktoros modellt (11. ábra), ahol a látens változók az előbbiekben feltárt faktorok voltak. Az 
elemzés elfogadható illeszkedést mutatott az elköteleződés forrásait vizsgálva (CMIN/d.f. = 1,$\left.66 ;\left(\mathrm{X}_{2}(708)=1177,21\right) ; \mathrm{CFI}=0,92 ; \mathrm{TLI}=0,91 ; \mathrm{RMSEA}=0,04 ; \mathrm{SRMR}=0,05\right) . \mathrm{Az}$ elemzések következtében arra a megállapításra jutottam, hogy a magyar viszonyok között a skála 52 tételes szerkezete alkalmas a további elemzéseim számára.

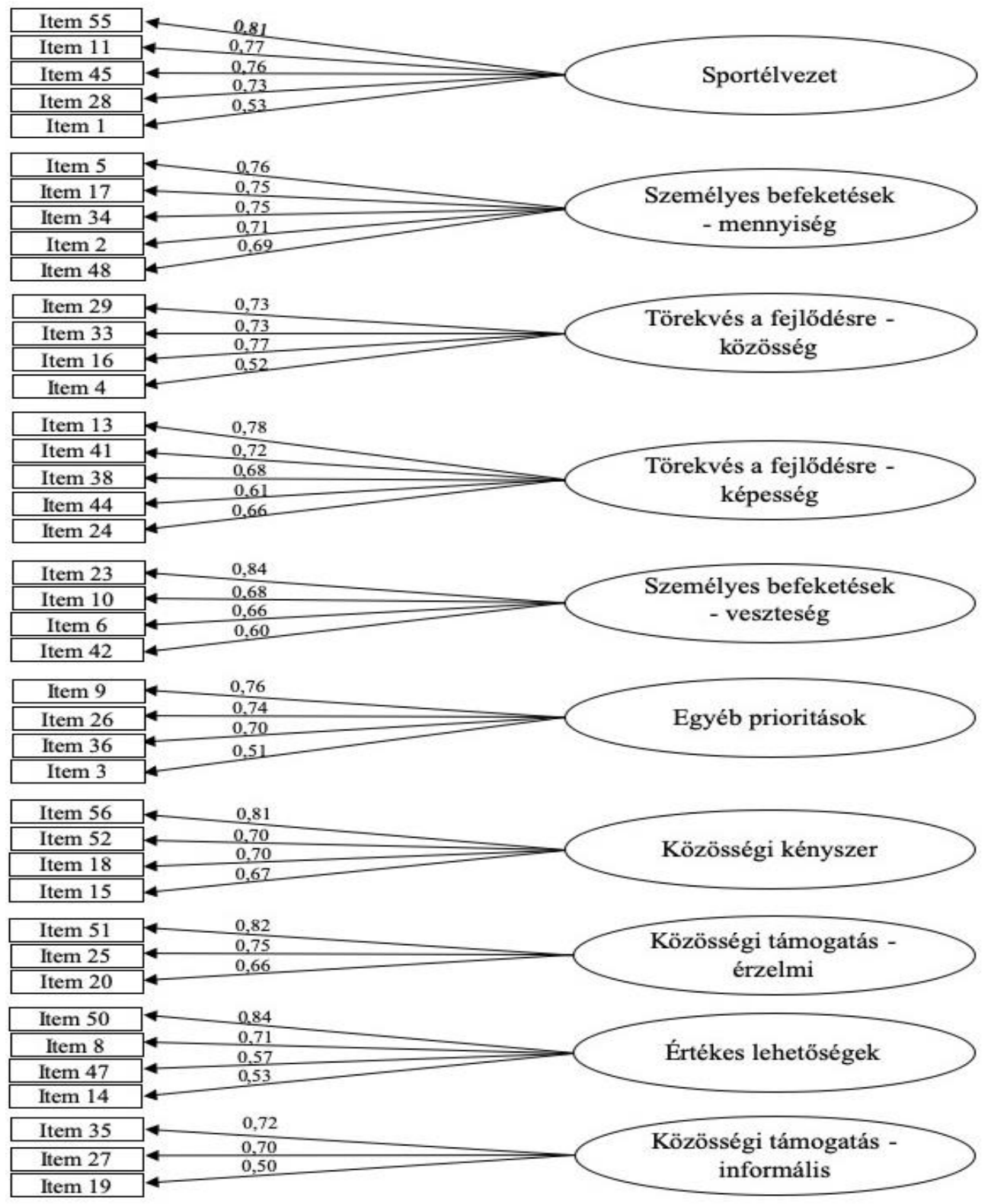

11. ábra. Elkötelezödés források faktor szerkezete és faktorsúlya a CFA elemzés szerint 


\section{A kérdöív megbizhatósága}

A skála szerkezetének feltárása után a megbízhatóságát is megvizsgáltam, melyhez három értéket alkalmaztam (AVE, CR, Chronbach Alpha). A faktorok értékeit, valamint azoknak a korrelációját a 3. táblázatban foglalom össze. Ahogy láthatjuk, a legtöbb értékünk megfelel az elvárt miniumoknak, de két faktor esetében (eröltetett elkötelezödés; közösségi támogatásinformális) az átlagos magyarázott variancia értéke kisebb, mint a minimum elvárható érték. Ugyanakkor, mint már utaltam rá, a szakirodalom szerint ezeknek a faktoroknak a megbízhatósága elfogadható, ha a CR értéke 0,60 fölött található (Malhotra és Dash, 2011; Huang és mtsai, 2013).

A korrelációs mátrix segítségével megvizsgálhatjuk a kapcsolatokat a kapott faktorok között. A lelkes elköteleződés valamennyi változóval kapcsolatot mutat, míg az eröltetett elkötelezödéssel és az egyéb prioritásokkal a kapcsolat negatív, a többi változóval pozitív kapcsolatban áll. Az eröltetett elkötelezödés negatívan korrelál a sportélvezet, törekvés a fejlödésre - képesség, közösségi támogatás - érzelmi és a közösségi támogatás - informális változókkal. Pozitív kapcsolat pedig a közösségi kényszer, egyéb prioritások és személyes befektetések - veszteséggel állnak fenn. 
3. táblázat. A sport-elköteleződés kérdőiv megbízhatósági mutatói és korrelációja

\begin{tabular}{|c|c|c|c|c|c|c|c|c|c|c|c|c|c|c|c|}
\hline & $\alpha$ & $\mathrm{CR}$ & AVE & 1 & 2 & 3 & 4 & 5 & 6 & 7 & 8 & 9 & 10 & 11 & 12 \\
\hline 1. Lelkes elkötelezödés & 0,90 & 0,91 & 0,61 & - & & & & & & & & & & & \\
\hline 2. Erőltetett elköteleződés & 0,63 & 0,66 & 0,31 & $-0,16 * *$ & - & & & & & & & & & & \\
\hline 3. Sportélvezet & 0,85 & 0,84 & 0,52 & $0,59^{* *}$ & $-0,34 * *$ & - & & & & & & & & & \\
\hline 4. Közösségi kényszer & 0,82 & 0,81 & 0,52 & $0,39 * *$ & $0,32 * *$ & $0,10 *$ & - & & & & & & & & \\
\hline 5. Egyéb prioritások & 0,78 & 0,78 & 0,47 & $-0,23 * *$ & $0,35 * *$ & $-0,17 * *$ & 0,01 & - & & & & & & & \\
\hline 6. Értékes lehetőségek & 0,75 & 0,76 & 0,45 & $0,65^{* *}$ & 0,07 & $0,31^{* *}$ & $0,55^{* *}$ & $-0,14 * *$ & - & & & & & & \\
\hline $\begin{array}{l}\text { 7.Törekvés a fejlődésre - } \\
\text { képesség }\end{array}$ & 0,78 & 0,82 & 0,47 & $0,72 * *$ & $-0,12 *$ & $0,50 * *$ & $0,38^{* *}$ & $-0,17 * *$ & $0,58^{* *}$ & - & & & & & \\
\hline $\begin{array}{l}\text { 8. Törekvés a fejlődésre - } \\
\text { közösség }\end{array}$ & 0,83 & 0,78 & 0,48 & $0,54 * *$ & 0,03 & $0,31 * *$ & $0,44 * *$ & $-0,12 *$ & $0,68^{* *}$ & $0,61 * *$ & - & & & & \\
\hline $\begin{array}{l}\text { 9. Személyes befektetések - } \\
\text { veszteség }\end{array}$ & 0,78 & 0,79 & 0,50 & $0,40 * *$ & $0,32 * *$ & 0,09 & $0,51 * *$ & 0,01 & $0,44 * *$ & $0,39^{* *}$ & 0,37 *** & - & & & \\
\hline $\begin{array}{l}\text { 10. Személyes befektetések } \\
\text { - mennyiség }\end{array}$ & 0,86 & 0,85 & 0,53 & $0,70^{* * *}$ & 0,02 & $0,34 * *$ & $0,53^{* *}$ & $-0,16$ *** & $0,72 * *$ & 0,67 ** & $0,68^{* *}$ & $0,48^{* *}$ & - & & \\
\hline $\begin{array}{l}\text { 11. Közösségi támogatás - } \\
\text { érzelmi }\end{array}$ & 0,78 & 0,78 & 0,55 & $0,38^{* *}$ & $-0,06$ & $0,24 * *$ & $0,40 * *$ & $-0,17 * *$ & $0,47 * *$ & $0,40 * *$ & $0,49 * *$ & $0,23^{* *}$ & 0,47 ** & - & \\
\hline $\begin{array}{l}\text { 12. Közösségi támogatás - } \\
\text { informális }\end{array}$ & 0,66 & 0,79 & 0,41 & $0,33^{* *}$ & $-0,22^{* *}$ & $0,11 *$ & $0,48^{* * *}$ & 0,09 & $0,41 * *$ & $0,25 * *$ & $0,30 * *$ & $0,28^{* *}$ & 0,36 ** & $0,41 * *$ & - \\
\hline
\end{tabular}

$$
{ }^{*} \mathrm{p}<0,01 ; * * \mathrm{p}<0,05
$$




\subsubsection{Megbeszélés}

A fejezetben célom volt, hogy bemutassam a sport-elköteleződés-2 kérdőív magyar változatát, annak faktor szerkezetét és megbízhatóságát. Célom volt továbbá, hogy választ kapjak az előzetesen feltett kérdésemre, azaz megtudjam megbízható-e a kérdőív magyar változta hazai környezetben.

Az elemzésemben egy véletlenszerüen kettéválasztott mintán feltártam és megerősítettem a kérdőív faktorszerkezetét, amelynek a végső változatának szerkezete egyezést mutatott a szakirodalom szerinti 12 alskálával (Scanlan és mtsai, 2016). Ugynakkor a vizsgált alskálák közül csak három egyezett meg teljesen a Scanlan és munkatársai (2016) által bemutatott kérdőív itemeivel (sportélvezet, erőltetett elköteleződés, lelkes elköteleződés). A kérdőív faktorai ugyan megegyeztek, de tételei valamelyest eltértek Scanlanék verziójától. A különbségek, úgy látom, hogy a minta sajátosságaiból és a kulturális különbségekböl adódhatnak (Stanley, 1996). Az eredeti tanulmány továbbá nagyobb elemszámmal dolgozott, ahol mindössze hat sportág részvevői (az én mintában 32 volt) vettek részt, mely nagyban hozzájárulhatott a kérdőív általánosíthatóságához. Emellett egyéb kulturális és nyelvi különbségek is befolyásolhatták az eredményeket. Például az 5-ös kérdés („Folyamatosan igyekszem magam fejleszteni ebben a sportágban”) a törekvés a fejlödésre-képesség faktorhoz tartozik az eredeti tanulmányban, de az eredményeimben mégis a személyes befeketések veszteség faktorhoz került. A mintában részt vevő sportolók úgy értelmezhették a kérdést, hogy az energia bevitelére és nem a képességek fejlödésére helyezték a hangsúlyt.

A vizsgált megbízhatósági mutatók (Cronbach alpha, AVE, CR) a kérdőív használhatóságát erősítik. Csupán az eröltetett elkötelezödés a közösségi támogatásinformálisnak volt alacsonyabb az AVE megbízhatósági értéke, de egyes tanulmányok szerint ezeket az értékeket is el lehet fogadni (Malhotra és Dash, 2011; Haung és mtsai, 2013). Érdemes megnézni, hogy milyen megbízhatósági mutatók jellemzik a skálát a nemzetközi szakirodalomban. Az eredeti tanulmányban például a CR értéke 0,71 és 0,92 között mozgott (a saját eredményeinkben: 0,66 - 0,91; Scanlan és mtsai, 2016). Míg Sánchez-Miguel (2019) tanulmányában spanyol nyelvre adaptálták a kérdőívet, ahol a teljesen skála Cronbach alpha értéke 0,87 , míg a vizsgálatomban 0,93 volt. 
A kapott faktorszerkezet a megbízhatósági értékek és a nemzetközi összehasonlítás is a skála használhatóságát igazolja még akkor is, ha nem egyezik meg teljesen az eredeti kérdőívvel.

\subsubsection{A sportélvezet kérdő́iv adaptációs vizsgálata}

A szakirodalom szerint sportélvezet nélkül nincs elköteleződés. Ezért vizsgálata külön figyelmet igényel. Wiersma (2001) kérdőíve nagyban hozzájárult a sportélvezet mélyebb megismeréséhez, éppen ezért fontosnak éreztem kutatásomban a kérdőív fordítását és adaptálását, hiszen a skála értékes eleme lehet magyar a szakirodalomnak is. A sportélvezet kérdőív vizsgálata is az első felmérésből származó adatok elemzésével valósult meg ( $\mathrm{n}=526)$.

\subsubsection{Statisztikai módszer}

A sportélvezet kérdőív feltárása az előző fejezetben taglalt statisztikai módszer alapján történt. Azaz a minta véletlenszerü kettéosztása után, elöször feltártam feltáró faktoranalízissel ( $\mathrm{n}=$ 201) a skála struktúráját, majd megerősítő faktoranalízis $(\mathrm{n}=325)$ segítségével tovább ellenőriztem azokat. A választott módszerek és fittségi mutatók megegyeztek az előző fejezetben leírtakkal (5.1.1.1. fejezet), így ebben a részben erre nem térek ki.

\subsubsection{Eredmények}

\section{Feltáró faktoranalízis.}

Az elemzés első részében faktoranalízisnek $(n=201)$ vetettem alá a kapott adatokat, melynél varimax rotációt alkalmaztam (4. táblázat). A Kaiser kritériumnak megfelelően az 1-nél nagyobb sajátértékkel rendelkező változókat vontam be a vizsgálatba. A táblázatban a 0,4-nél magasabb faktorsúlyú változókat tüntettem fel az eredmények könnyebb interpretálhatósága érdekében. A faktorok a teljes variancia 67,68\%-át magyarázták meg összesen, mely jól jellemezte a mintámat.

Ezek alapján a 28 tételt 6 különböző faktorba tudtam csoportosítani. Az első faktornak a versenyzés izgalma nevet adtam, ahová a legtöbb változó került. Ez a faktorváltozó azokat az állításokat foglalja magába, amelyek a sportversenyek élményével kapcsolatosak (pl.: „hallom a tömeg éljenzését játék vagy meccs közben”). A következő faktort csapatszellemnek neveztem el. A sporttal összefüggő társas kapcsolatok változói kerültek ide, ilyen például a következő: „A 
csapatszellemtől és az összetartozástól egy csapat tagjának érzem magam”. A harmadik faktor az eröfeszités jutalma nevet kapta. Itt olyan változók játszanak szerepet, mint a „Keményen dolgozom az edzéseken.” Az negyedik faktor a szülői támogatás lett, ebben olyan ismérvek találhatók, amelyekben a sportolók a szülők támogatásáról nyilatkoznak (pl.: „Bátorítást kapok a szüleimtöl”). Az ötödik faktor a másokhoz viszonyított kompetencia nevet viseli, amely nem jelent mást, mint az ellenfelek legyőzését és mások általi elismerést. Ilyen változó például: „Megmutathatom, hogy jobb vagyok a sportágamban, mint más.” Az utolsó faktornak a saját kompetencia elnevezés jutott. Ide azok a kérdések tartoznak, ahol a sportolók saját maguk teljesítményét értékelik, ilyen elem például „A teljesítményem javult a múlthoz képest.” 


\begin{tabular}{|c|c|c|c|c|c|c|}
\hline & \multicolumn{6}{|c|}{ Faktorsúly } \\
\hline & 1 & 2 & 3 & 4 & 5 & 6 \\
\hline 24. izgatottá tesz a versenyzés. & 0,75 & & & & & \\
\hline 22. lelkesít a versenyzés. & 0,75 & & & & & \\
\hline 13. keményen játszom a versenyek alatt. & 0,68 & & & & & \\
\hline $\begin{array}{l}\text { 15. hallom a tömeg éljenzését játék, meccs vagy verseny } \\
\text { közben. }\end{array}$ & 0,61 & & & & & \\
\hline 8. részt veszek játékokon, találkozókon és versenyeken. & 0,59 & & & & & \\
\hline 4. barátokkal vagyok egy csapatban. & & 0,85 & & & & \\
\hline 7. támogatást és bátorítást kapok a csapattársaktól. & & 0,75 & & & & \\
\hline 10. új barátokat találok a sportágamban. & & 0,74 & & & & \\
\hline $\begin{array}{l}\text { 6. a csapatszellemtől és az összetartozástól egy } \\
\text { csapattagjának érzem magam. }\end{array}$ & & 0,73 & & & & \\
\hline $\begin{array}{l}\text { 11. edzésen és versenyen kívül is találkozok a } \\
\text { csapattársakkal. }\end{array}$ & & 0,72 & & & & \\
\hline 2. keményen dolgozom az edzéseken. & & & 0,79 & & & \\
\hline 1. kihasználom a lehetőségeimet. & & & 0,79 & & & \\
\hline $\begin{array}{l}\text { 9. részt veszek keményedzéseken és be tudom fejezni } \\
\text { azokat. }\end{array}$ & & & 0,63 & & & \\
\hline $\begin{array}{l}\text { 3. a teljesítményem javulása lehetővé teszi, hogy másokat } \\
\text { felülmúljak. }\end{array}$ & & & 0,58 & & & \\
\hline $\begin{array}{l}\text { 27. elérem a célom, melyet a saját teljesítményem alapján } \\
\text { állítok fel. }\end{array}$ & & & 0,56 & & & \\
\hline $\begin{array}{l}\text { 26. nagy erőfeszítéseket teszek az edzéseken és } \\
\text { versenyeken. }\end{array}$ & & & 0,52 & & & \\
\hline 17. bátorítást kapok a szüleimtől. & & & & 0,82 & & \\
\hline 23. támogatást kapok a szüleimtől, ha a sportomat üzöm. & & & & 0,82 & & \\
\hline $\begin{array}{l}\text { 28. a szüleim meg vannak elégedve a teljesítményemmel } \\
\text { bármi történjen is. }\end{array}$ & & & & 0,68 & & \\
\hline 25. a szüleim megnéznek versenyzés közben. & & & & 0,56 & & \\
\hline $\begin{array}{l}\text { 5. olyan gyakorlatokat tudok, melyeket a velem egykorú } \\
\text { társaim nem. }\end{array}$ & & & & & 0,79 & \\
\hline 18. jobb vagyok a kortársaimnál a saját sportágamban. & & & & & 0,76 & \\
\hline $\begin{array}{l}\text { 19. mások felismernek, mivel részt veszek ebben a } \\
\text { sportban. }\end{array}$ & & & & & 0,57 & \\
\hline $\begin{array}{l}\text { 16. megmutathatom, hogy jobb vagyok a sportágamban, } \\
\text { mint más. }\end{array}$ & & & & & 0,52 & \\
\hline 12. mint sportoló sokan megismernek. & & & & & & 0,50 \\
\hline 21. jobban játszom most, mint a múltban. & & & & & & 0,74 \\
\hline 14. a teljesítményem javult a múlthoz képest. & & & & & & 0,72 \\
\hline$\%$-os variancia & 40.57 & 7.69 & 6.35 & 5.54 & 3.91 & 3.68 \\
\hline Sajátérték & 11.36 & 2.15 & 1.78 & 1.55 & 1.09 & 1.03 \\
\hline
\end{tabular}


Megerösítő faktoranalízis

Az adaptáció következő lépésében megerősítő faktoranalízissel is megvizsgáltam a kapott eredményeimet ( $\mathrm{n}=325)$. Wiersma (2001) elméletének ajánlásai alapján egy hat-, valamint egy négyfaktoros modellt állítottam fel az AMOS 22.0 segítségével. A hatfaktoros modell látens változói a feltáró elemzéssel kapott faktorok voltak (versenyzés izgalma; eröfeszités jutalma; csapatszellem; saját kompetencia; szülői támogatás; másokhoz viszonyított kompetencia), míg a négyfaktoros modell elemei a kétdimenziós sportélvezet modell kvadránsai voltak (intrinzik teljesítménnyel összefüggö; extrinzik - teljesítménnyel összefüggö; intrinzik - teljesítménytöl független; extrinzik - teljesítménytöl független). Az eredményeket a 5. táblázatban foglaltam össze. Ahogy láthatjuk, a hatfaktoros modell minimálisan, de jobb fittségi mutatókkal rendelkezik, mint a négyfaktoros verzió, így további elemzéseimet a hatfaktoros modell alapján végeztem el.

5. táblázat. A sportélvezet skála fittségi mutatóit két modell esetében

\begin{tabular}{lllllll}
\hline Modell & $\mathrm{X}_{2}$ & CMIN/d.f & RMSEA & TLI & CFI & SRMR \\
\hline $\begin{array}{l}6 \text { faktoros } \\
\text { modell }\end{array}$ & 808,49 & 2,51 & 0,54 & 0,93 & 0,94 & 0,05 \\
$\begin{array}{l}4 \text { faktoros } \\
\text { modell }\end{array}$ & 881,39 & 2,79 & 0,58 & 0,92 & 0,93 & 0,07 \\
\hline
\end{tabular}

Megbízhatóság

A skála megbízhatóságára csakúgy, mint az előző fejezetben három mutatót használtam (AVE, CR, Alpha). Ezeket az 6. táblázatban foglaltam össze. Ahogy láthatjuk a legtöbb mutató elérte a kívánt szintet, ugyanakkor az AVE mutató három esettben is alacsonyabb volt. Ez a mutató a legérzékenyebb az elemszámra, item számra és varianciára, így Malhotra és Dash (2011) ajánlásai alapján járunk el. Az eredményeimben a CR értéke 0,60 fölé esik, így a megbízhatóságot elfogadhatónak tekintem. 
6. táblázat. A sportélvezet kérdőiv megbízhatósági mutatói

\begin{tabular}{lcccccc}
\hline & $\begin{array}{c}\text { Versenyzés } \\
\text { izgalma }\end{array}$ & Csapatszellem & $\begin{array}{c}\text { Erőfeszítés } \\
\text { jutalma }\end{array}$ & $\begin{array}{c}\text { Szülői } \\
\text { támogatás }\end{array}$ & $\begin{array}{c}\text { Másokhoz } \\
\text { viszonyított } \\
\text { kompetencia }\end{array}$ & $\begin{array}{c}\text { Saját } \\
\text { kompetencia }\end{array}$ \\
\hline AVE & 0,48 & 0,60 & 0,48 & 0,55 & 0,43 & 0,53 \\
CR & 0,73 & 0,88 & 0,84 & 0,82 & 0,74 & 0,77 \\
Alpha & 0,86 & 0,94 & 0,86 & 0,82 & 0,84 & 0,71 \\
\hline
\end{tabular}

\subsubsection{Megbeszélés}

A fejezet célja volt, hogy bemutassam a kutatásomban használt Wiersma (2001) által kifejlesztett sportélvezet skála magyar nyelvü változatát, szerkezetét és megbízhatóságát. A kérdőív faktorszerkezetét feltáró, valamint megerősítő faktoranalízissel is ellenőriztem. A megfelelő megbízhatóság érdekében több mutatót is használtam.

A végső feltáró elemzés hat faktor meglétét erősítette meg, mely 27 tételt tartalmazott. A faktorok száma és leírása azonos volt az eredeti kérdőívvel, de tételeiben minimálisan eltért. Azonban ez a különbség nem befolyásolja a kérdőív használhatóságát a későbbi elemzésekben. Fontos továbbá kitérni a kapott alskálára, melyek leírják a sportélvezet modellt és összehangban vannak más motivációs elméletekkel is. Például a külső - belső megközelítésnek köszönhetően kapcsolat látható az öndeterminációs elmélettel (Deci és Ryan, 2000), vagy érdekes párhuzamot lehet vonni a versenyzés izgalmát leíró faktor és a célorientációs elmélet között (Locke és Latham, 1985). Ezen kapcsolatok miatt gondolom különösen úgy, hogy a kapott változók képesek vizsgálni az élvezet különböző forrásait.

A hatfaktoros modell mellett a négyfaktoros modellt is megvizsgáltam Wiersma (2001) javaslatai alapján. A modell nem bírt kiemelkedő illeszkedési mutatókkal, de véleményem szerint nem szabad teljesen elvetni a további vizsgálat során, hiszen érdekes megközelítéssel szolgálhatnak a sportélvezet kutatásában az extrinzik - intrinzik és teljesítménytől függő teljesítménytől független dimenziók. A szakirodalom is számos hasonló megközelítéssel rendelkezik a sportélvezet kutatásokban (pl.: Santos és Gonçalves, 2012).

Végezetuil fontos, hogy megemlítsem a kérdőív megbízhatóságát. Ahogy láthatjuk a legtöbb alskála megbízhatósági mutatója elérte a minimum elvárt szinttől a hatfaktoros modell esetében, sőt az eredeti tanulmányhoz képest lényegesebben jobb mutatókkal rendelkezik (eredeti skála alpha értéke: 0,65-0,85; az adaptált skála alpha értéke: 0,71-0,94). Mint már 
láthattuk a szakirodalom különböző véleményen van az egyes mutatókkal kapcsolatban, ezért a kérdőívünk a megengedett szinten belül van és így megbízható a magyar serdülő populáció körében.

Mivel a sportélvezet az egyik legfontosabb forrása az elköteleződésnek, a kérdőív vizsgálata kutatásomban központi helyen áll. Úgy látom fontos megvizsgálni, hogy a fiatalok miért is szeretnek sportolni, mert az nagyban hozzájárulhat a sport minél szélesebb elterjedéséhez.

\subsubsection{A magyar változatú sportolói identitás skála adaptációs vizsgálata}

A Sportolói Identitás Skálát (Athletic Identity Measurement Scale - AIMS) széles körben használják a külföldi kutatók a sportolói önazonoság meghatározására, ugyanakkor hazánkban kevésbé ismert. Ezért a fejezet célja, bemutatni a sportolói identitás skálát (AIMS-H), annak magyar változatát, faktorszerkezetét és szociodemográfiai jellemzőit. A sportolói identitás skála adaptációs vizsgálata is a második felmérésből származó adatok elemzésével valósult meg.

\subsubsection{Statisztikai módszer}

A szakirodalom a skálát egy dimenzióban jellemzi (Brewer és mtsai, 1993). Így a leíró statisztika mellet csupán megerősítő faktoranalízissel elemeztem az adatokat. A fittségi mutatók közül az 5.1.1.1. fejezetben leírtak alapján jártam el, így a következő fittségi mutatókat használtam: X2; CMIN/df; TLI; CFI; RMSEA; SRMR. Az adatok illeszkedését a teljes mintán, valamint a szociodemográfiai adatok és sportolási jellemzők (nem, kor, sportágtípus, sportolási szint) mentén létrehozott almintánkon keresztül, is elvégeztem. A skála belső megbízhatóságának kimutatására csak úgy, mint az előzőekben a Cronbach-féle alphát, az indikátorokhoz tartozó fogalmi megbízhatósági mutatót és az átlagos magyarázott variancia értékeket használtam fel. Az elfogadási kritériumokra az 5.1.1.1. -es fejezetben leírtak érvényesek így azokra nem térek ki újból. 


\subsubsection{Eredmények}

\section{Megerösitő faktoranalízis}

A megerősítő faktoranalízis igazolta a skála egydimenziós szerkezetét (12. ábra). A teljes mintán végzett vizsgálat kiváló illeszkedést mutatott a felállított modellünkkel $(\mathrm{CMIN} / \mathrm{d}$.f. = $\left.1,40\left(\mathrm{X}_{2}(23)=32,27\right) \mathrm{CFI}=0,99, \mathrm{TLI}=0,99, \mathrm{RMSEA}=0,03 \mathrm{SRMR}=0,03\right)$.

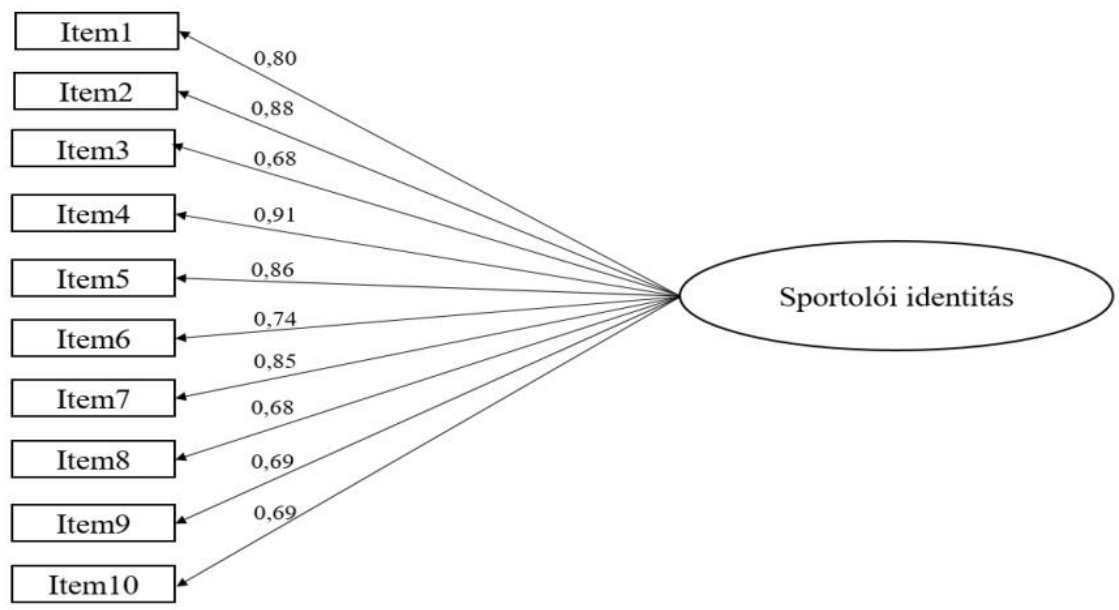

12. ábra. A sportolói identitás skála egy dimenziós faktorszerkezete és faktorsúlyai

A teljesmintás vizsgálat után alskálákra osztottam a mintát és megvizsgáltam nem, kor, sportolási szint és a sportágak között az illeszkedési mutatókat. A kis elemszám ellenére az almintákon végzett vizsgálatok is megfelelő illeszkedést és megbízhatósági értékeket eredményeztek, melyek a 7. táblázatban részletezek. A TLI, CFI fittségi mutatók 0,90 és 0,99 között ingadoztak.

7. táblázat. Sportolói identitás skála megbizhatósága a teljes mintán és almintákon

\begin{tabular}{lcccccccc}
\hline Alminta & $\mathrm{n}$ & $\mathrm{x} 2$ & $\mathrm{df}$ & CMIN/df & TLI & CFI & RMSEA & SRMS \\
\hline Fiúk & 130 & 16,02 & 23 & 1,23 & 0,99 & 0,99 & 0,04 & 0,05 \\
Lányok & 210 & 21,82 & 21 & 1,03 & 0,99 & 0,99 & 0,01 & 0,02 \\
$14-16$ & 177 & 29,48 & 21 & 1,40 & 0,98 & 0,99 & 0,04 & 0,05 \\
$17-19$ & 163 & 24,54 & 21 & 1,16 & 0,99 & 0,99 & 0,03 & 0,04 \\
Válogatott & 56 & 22,73 & 21 & 1,82 & 0,98 & 0,99 & 0,03 & 0,06 \\
Országos & 156 & 32,14 & 20 & 1,60 & 0,95 & 0,98 & 0,05 & 0,05 \\
Helyi & 59 & 38,18 & 25 & 1,97 & 0,95 & 0,94 & 0,05 & 0,05 \\
Hobbi & 66 & 23,11 & 19 & 1,21 & 0,93 & 0,98 & 0,05 & 0,03 \\
Egyéni & 174 & 24,86 & 19 & 1,30 & 0,99 & 0,99 & 0,04 & 0,04 \\
Csapat & 160 & 22,13 & 19 & 1,16 & 0,99 & 0,99 & 0,03 & 0,02 \\
\hline
\end{tabular}




\section{Megbízhatóság}

Megvizsgáltam a skála megbízhatóságát a teljes mintán, valamint az almintákon egyaránt (8. táblázat). Csakúgy, mint az illeszkedési mutatók a kérdőív megbízhatósági mutatói is stabil értékeket mutattak (a teljes mintán: Cronbach-alpha=0,95; $\mathrm{CR}=0,93 ; \mathrm{AVE}=0,59$ ). Az átlagos magyarázott variancia értéke azonban egyes almintákon nem érte el a kívánt minimumot. Ilyen történt a „fiúk”, „17-19”, „Válogatott” és „Országos” alminták esetében. Ennek ellenére a magas Cronbach alpha és a fogalmi megbízhatósági mutatók magas értékei megbízhatóságra utalnak skálánk almintái tekintetében is.

\section{8. táblázat. Sportolói identitás skála megbízhatósága a teljes mintán és almintákon}

\begin{tabular}{lccc}
\hline Alminta & Cronbach-Alpha & AVE & CR \\
\hline Teljes minta & 0,95 & 0,59 & 0,93 \\
Fiúk & 0,87 & 0,43 & 0,88 \\
Lányok & 0,94 & 0,62 & 0,94 \\
$14-16$ & 0,91 & 0,52 & 0,91 \\
$17-19$ & 0,94 & 0,60 & 0,93 \\
Válogatott & 0,79 & 0,37 & 0,83 \\
Országos & 0,85 & 0,39 & 0,86 \\
Helyi & 0,88 & 0,51 & 0,83 \\
Hobbi & 0,87 & 0,40 & 0,86 \\
Egyéni & 0,93 & 0,59 & 0,93 \\
Csapat & 0,91 & 0,52 & 0,91 \\
\hline
\end{tabular}

\subsubsection{Megbeszélés}

A fejezet célja a magyar nyelvü sportolói identitás skála faktorstruktúrájának és megbízhatóságának vizsgálata volt. A kapott értékek azt mutatják, hogy a kérdőív megbízhatóan használható a magyar serdülő sportolópopuláción.

A megerősítő faktoranalízis segítésével a szakirodalomban ismert struktúrát teszteltem, ahol a tíz tételt egy faktornak tekintik (Brewer és mtsai, 1993). Meg kell említeni, hogy egyes kutatók a skála több dimenzióját is megkülönböztetik (Lamont-Mills és Christensen, 2006), ám a kérdések hasonlósága miatt számomra az egydimenziós szerkezet tünik reálisabbnak. A szakirodalom használja továbbá az ún. sportolói identitás indexet, melyet a teljes mintára adott pontok alapján számolnak ki, így ez a megközelítés is az egy faktoros struktúrát erősíti. A 
kérdőív magyar változatának szerkezete teljes mértékben megegyezett a Brewer és munkatársai (1993) által publikált változattal és illeszkedési mutatói közel azonosak voltak.

A kérdőív megbízhatóságát vizsgálva arra következtetésre jutottam, hogy a kérdőív jó megbízhatósággal rendelkezik annak ellenére, hogy egyes alskálákon alacsonyabb volt az AVE megbízhatósági mutató. A szakirodalmat vizsgálva is hasonló értékekre bukkanunk. Például Sheikh (2015) alacsonyabb mintán hasonló Cronbach alpha értéket ért el $(n=107$; alpha = 0,94). Ezek alapján és a szakirodalmi összevetéssel együtt úgy látom, hogy a kérdőív fordítása, szerkezete megfelelő és jól használható a magyar serdülőpopuláción.

A skála jövőbeli felhasználása számos lehetöséget rejt magában. Először is a kérdőívvel talán könnyebben lehet vizsgálni a nem sportoló diákokat, hiszen a sportolói identitás indexnek köszönhetően számszerüsíteni tudjuk a sportolási vágyat. Ezen túl a skála támpontot adhat további motivációs kutatásoknak is, hiszen a magas önazonosság megléte közel állhat a sportolók motivációjához is. A skálával célom a motiváció, valamint az elköteleződés minél szélesebbkörü megismerése.

\subsection{Sportolási szokások és a szociodemográfia szerepe a sport-elköteleződés modellben}

A sport iránti elköteleződésre számtalan tényező hathat, ezért a következőkben a sportelköteleződés modellre ható szociodemográfiai változókat és sportolási szokásokat mutatom be, valamint kitérek arra, hogy milyen különbségek találhatóak a sport iránti elköteleződés forrásai és típusai között sportáganként elemezve. Az alfejezetek az előzőekben felállított második kérdéskörre és a hipotézisére $\left(\mathrm{H}_{2}\right)$ igyekeznek választ adni.

\subsubsection{A sport iránti elköteleződés összefüggése a sportolási szokásokkal és demográfiai tényezőkkel}

A fejezet célja bemutatni a sport iránti elköteleződést, sportolási szokásokat a demográfiai összefüggéseken keresztül. A vizsgálatomat az első adatgyüjtésből származó adatok ( $\mathrm{n}=526$ ) alapján végeztem el, ahol a sport-elköteleződés kérdőív-2, valamint a szociodemográfiai és a sportolási szokásokkal kapcsolatos kérdéseket elemeztem. 


\subsubsection{Statisztikai módszer}

Az adatok feldolgozását SPSS programmal végeztem. Az adatelemzésnél a leíró statisztika mellett a szociodemográfiai adatok és a sport iránti elköteleződés közötti kapcsolatok tendenciáinak megállapítására többváltozós lineáris regressziót („stepwise” módszer) alkalmaztam.

\subsubsection{Eredmények}

Adatok elemzését a sport-elköteleződés típusok és a szociodemográfiai adatok közötti kapcsolat vizsgálatával kezdtem. A 9. táblázat a két elköteleződés típust befolyásoló változókat mutatja be, a többváltozós lineáris regresszióelemzés „stepwise” módszert alkalmazva. Az erőltetett elköteleződés esetében a magyarázó erő alacsony értéke miatt nem elemeztem tovább. A lelkes elköteleződés modelljébe elsőként az edzésmennyiség $(\beta=0,307 ; \mathrm{p}<0,001)$ került be a magyarázó változók közé, majd ezt a kor $(\beta=-0,104 ; \mathrm{p}<0,001)$, a sportolási szint $(\beta=0,167$; p < 0,001) és a nem $(\beta=-0,108 ; \mathrm{p}<0,001)$ követte. Ahogy eredményeinkböl látszik, a kor fordított összefüggést mutat a lelkes elkötelezödéssel, azaz minél idősebb valaki, úgy csökken sportága iránti motivációja. A nem tekintetében is hasonló eredmény rajzolódik ki. Itt azt láthatjuk, hogy a fiúk jobban elkötelezettek, mint a lányok. A bevitt változók a variancia 26\%át magyarázzák meg.

9. táblázat. A sport-elkötelezödés típusát befolyásoló független változók , stepwise” regresszióanalízis eredményének kivonata

\begin{tabular}{|c|c|c|}
\hline & Lelkes elköteleződés & Erőltetett elköteleződés \\
\hline $\begin{array}{c}\text { Koefficiensek a } \beta \\
\text { regressziós együtthatóval }\end{array}$ & $\begin{array}{l}\text { 1. Edzésmennyiség } \\
\beta=0,307 * * * \\
2 . \text { Kor } \\
\beta=-0,145^{* * *} \\
\text { 3. Sportolási szint } \\
\beta=0,167 * * \\
\text { 4. Nem } \\
\beta=-0,108 * *\end{array}$ & $\begin{array}{l}\text { 1. Edzésmennyiség } \\
\beta=0,134 * * *\end{array}$ \\
\hline Modell jellemzői & $\mathrm{R}_{2}=0,263 * * *$ & $\mathrm{R}_{2}=0,018 * * *$ \\
\hline Kizárt változók & $\begin{array}{l}\text { sporttagozat. osztály, anyagi } \\
\text { helyzet, mióta sportolsz? } \\
\text { egyéni/csapat sportág }\end{array}$ & $\begin{array}{l}\text { nem, kor, osztály, sporttagozat } \\
\text { anyagi helyzet, mióta sportolsz, } \\
\text { sportolási szint, egyéni/csapat }\end{array}$ \\
\hline
\end{tabular}


A sport-elköteleződés forrásainak elemzését két részre osztottam. Először azokat a faktorokat elemeztem, amelyek az egyéni szintü (10. táblázat), majd azokat, amelyek a közösségi szintü forrásokat tartalmazzák (11. táblázat). Az egyéni szintü forrásoknál láthatjuk, hogy az értékes lehetőségek három változóval függenek össze, melyek a sportolási szint ( $\beta=$ 0,485; $\mathrm{p}<0,001)$, az edzésmennyiség $(\beta=0,187 ; \mathrm{p}<0,001)$ és a ,Hányadik osztályba jársz?” kérdésre adott változó $(\beta=-0,110 ; \mathrm{p}<0,001)$. Ez utóbbi negatív elöjelü, és hasonlóan a korhoz, az évek elörehaladtával ez is csökken. Az értékes lehetőségek változó a variancia 41\%-át magyarázza. A törekvés a fejlödésre - egyéni alksála két változója - melyek az edzésmennyiség $(\beta=0,374 ; \mathrm{p}<0,001)$ és a sportolási szint voltak $(\beta=0,173 ; \mathrm{p}<0,01), 25 \%$-os magyarázó erővel bírnak. A személyes befektetéseket két alskálán keresztül is vizsgáltam. Az első a mennyiség, melyet nagymértékben befolyásol az edzésmennyiség $(\beta=0,431 ; \mathrm{p}<0,001)$, a sportolási szint $(\beta=0,298 ; \mathrm{p}<0,001)$, a kor $(\beta=-0,095 ; \mathrm{p}<0,01)$, és hogy mióta sportol valaki $(\beta=0,091 ; p<0,01)$. Itt volt a legmagasabb magyarázó érték, mely 53\%. A személyes befektetések - veszteség hasonlóképpen alakult: az edzésmennyiség $(\beta=0,302 ; \mathrm{p}<0,001)$, a sportolási szint $(\beta=-0,163 ; \mathrm{p}<0,001)$, a $\operatorname{kor}(\beta=-0,081 ; \mathrm{p}<0,01)$. A személyes befektetések veszteségnél a magyarázó erő már jóval kisebb volt (20\%), mint az előző modellnél. A sportélvezet és az egyéb prioritások elemzését az alacsony magyarázó erő miatt nem elemeztem. 
10. táblázat. A sport-elkötelezödés forrásait befolyásoló független változók „, stepwise” regresszióanalízis eredményének kivonata I.

\begin{tabular}{|c|c|c|c|c|c|c|}
\hline & $\begin{array}{l}\text { Értékes } \\
\text { lehetőségek }\end{array}$ & Sportélvezet & $\begin{array}{l}\text { Törekvés a } \\
\text { fejlődésre - } \\
\text { képesség }\end{array}$ & $\begin{array}{l}\text { Egyéb } \\
\text { prioritások }\end{array}$ & $\begin{array}{l}\text { Személyes } \\
\text { befektetések - } \\
\text { mennyiség }\end{array}$ & $\begin{array}{l}\text { Személyes } \\
\text { befektettetések - } \\
\text { veszteség }\end{array}$ \\
\hline $\begin{array}{l}\text { Koefficiensek } \\
\text { a } \beta \text { regressziós } \\
\text { együtthatóval }\end{array}$ & $\begin{array}{l}\text { 1. Sportolási } \\
\text { szint } \\
\beta=0,485 * * * \\
2 . \\
\text { Edzésmennyiség } \\
\beta=0,187 * * * \\
\text { 3. Osztály } * * \\
\beta=-0,110\end{array}$ & $\begin{array}{l}\text { 1. } \\
\text { Edzésmennyiség } \\
\beta=0,150 * * * \\
2 . \text { Egyéni /csapat } \\
\text { sportág } \\
\beta=-0,095 *\end{array}$ & $\begin{array}{l}\text { 1. } \\
\text { Edzésmennyiség } \\
\beta=0,374 * * * \\
2 . \text { Sportolási } \\
\text { szint } \\
\beta=-0,173 * *\end{array}$ & $\begin{array}{l}\text { 1.Sportolási } \\
\text { szint } \\
\beta=0,168 * * * \\
2 . \text { Nem } \\
\beta=-0,100 *\end{array}$ & $\begin{array}{l}\text { 1. } \\
\text { Edzésmennyiség } \\
\beta=0,431 * * * \\
\text { 2. Sportolási } \\
\text { szint } \\
\beta=0,298 * * * \\
\text { 3. Kor } \\
\beta=-0,095 * * \\
\text { 4. Mióta } \\
\text { sportolsz? } \\
\beta=0,091 * *\end{array}$ & $\begin{array}{l}\text { 1. Edzésmennyiség } \\
\beta=0,302 * * * \\
\text { 2. Sportolási szint } \\
\beta=0,163 * * \\
\text { 3. Kor } \\
\beta=-0,081 *\end{array}$ \\
\hline
\end{tabular}

\begin{tabular}{|c|c|c|c|c|c|c|}
\hline $\begin{array}{l}\text { Modell } \\
\text { jellemzői }\end{array}$ & $\mathrm{R}_{2}=0,413 * * *$ & $\mathrm{R}_{2}=0,018 * * *$ & $\mathrm{R}_{2}=0,257 * * *$ & $\mathrm{R}_{2}=0,034 * * *$ & $\mathrm{R}_{2}=0,523 * * *$ & $\mathrm{R}_{2}=0,201 * * *$ \\
\hline $\begin{array}{l}\text { Kizárt } \\
\text { változók }\end{array}$ & $\begin{array}{l}\text { nem, kor, } \\
\text { sporttagozat, } \\
\text { anyagi helyzet, } \\
\text { mióta sportolsz, } \\
\text { egyéni/csapat } \\
\text { sporttág }\end{array}$ & $\begin{array}{l}\text { nem, kor, } \\
\text { osztály, } \\
\text { sporttagozat } \\
\text { anyagi helyzet, } \\
\text { mióta sportolsz, } \\
\text { sportolási szint, }\end{array}$ & $\begin{array}{l}\text { nem, kor, } \\
\text { osztály, } \\
\text { sporttagozat, } \\
\text { anyagi helyzet, } \\
\text { mióta sportolsz, } \\
\text { egyéni/csapat } \\
\text { sporttág }\end{array}$ & $\begin{array}{l}\text { kor, osztály, } \\
\text { sporttagozat } \\
\text { anyagi } \\
\text { helyzet, mióta } \\
\text { sportolsz, } \\
\text { sportolási } \\
\text { szint, } \\
\text { egyéni/csapat } \\
\text { sporttág }\end{array}$ & $\begin{array}{l}\text { nem, osztály, } \\
\text { sporttagozat, } \\
\text { anyagi helyzet, } \\
\text { egyéni/csapat } \\
\text { sporttág }\end{array}$ & $\begin{array}{l}\text { nem, osztály, } \\
\text { sporttagozat, anyagi } \\
\text { helyzet, mióta } \\
\text { sportolsz, } \\
\text { egyéni/csapat } \\
\text { sporttág }\end{array}$ \\
\hline
\end{tabular}

$* \mathrm{p}<0,05 ; * * \mathrm{p}<0,01 ; * * * \mathrm{p}<0,001$ 
A vizsgálat következő részében a közösségi szintü forrásokat elemeztem (11. táblázat). A közösségi kényszer alskálát öt változó magyarázza mintegy 24\%-os magyarázó erővel. Ezek a sportolási szint $(\beta=0,299 ; \mathrm{p}<0,001), \operatorname{kor}(\beta=-0,137 ; \mathrm{p}<0,01)$, nem $(\beta=-0,106 ; \mathrm{p}<0,01)$, anyagi helyzet $(\beta=-0,117 ; \mathrm{p}<0,01)$ és az edzésmennyiség $(\beta=0,129 ; \mathrm{p}<0,05)$. A közösségi támogatás kérdőívünk két típust is vizsgált. Az érzelmi szintü közösségi támogatást (magyarázó ereje: $25 \%)$ pozitívan befolyásolja a sportolási szint $(\beta=0,431 ; \mathrm{p}<0,001)$, és negatívan a sporttagozat $(\beta=-0,232 ; \mathrm{p}<0,05)$, azaz azoknak a sportolóknak, akik nem sporttagozatos osztályban tanulnak, fontosabb a közösségi támogatás. A közösségi támogatás - informális leginkább befolyásoló változói a sportolási szint $(\beta=0,288 ; \mathrm{p}<0,001)$, az edzésmennyiség ( $\beta$ $=0,168 ; \mathrm{p}<0,01)$, az osztály $(\beta=-0,106 ; \mathrm{p}<0,01)$ és az anyagi helyzet $(\beta=-0,110 ; \mathrm{p}<0,01)$. A közösségi támogatás - informális magyarázó ereje $21 \%$. Utolsó skála a törekvés a fejlödésre - közösség, aminek mértéke elsődlegesen a sportolási szinttöl $(\beta=0,425 ; \mathrm{p}<0,001)$, a sportág típusától $(\beta=0,150 ; \mathrm{p}<0,001)$, az edzés mennyiségétől $(\beta=0,178 ; \mathrm{p}<0,001)$ és a nemtöl $(\beta=$ $-0,086 ; \mathrm{p}<0,05)$ függ. 
11. táblázat. A sport-elkötelezödés forrásait befolyásoló független változók „, stepwise” regresszióanalizis eredményének kivonata II.

\begin{tabular}{|c|c|c|c|c|}
\hline & Közösségi kényszer & $\begin{array}{l}\text { Közösségi támogatás } \\
\text { - érzelmi }\end{array}$ & $\begin{array}{l}\text { Közösségi támogatás } \\
\text { - informális }\end{array}$ & $\begin{array}{l}\text { Törekvés a fejlödésre - } \\
\text { közösség }\end{array}$ \\
\hline $\begin{array}{l}\text { Koefficiensek } \\
\text { a } \beta \text { regressziós } \\
\text { együtthatóval }\end{array}$ & $\begin{array}{l}\text { 1. Sportolási szint } \\
\beta=0,299 * * * \\
\text { 2. Kor } \\
\beta=-0,137 * * \\
\text { 3. Nem } \\
\beta=-0,106 * * \\
\text { 4. Anyagi helyzet } \\
\beta=0,117 * * \\
\text { 5. Edzésmennyiség } \\
\beta=0,129 *\end{array}$ & $\begin{array}{l}\text { 1. Sportolási szint } \\
\beta=0,431 * * * \\
\text { 2. Sporttagozat } \\
\beta=-0,232 *\end{array}$ & $\begin{array}{l}\text { 1. Sportolási szint } \\
\beta=0,288 * * * \\
\text { 2. Edzésmennyiség } \\
\beta=0,168 * * \\
\text { 3. Osztály } \\
\beta=-0,106 * * \\
\text { 4. Anyagi helyzet } \\
\beta=0,110 * *\end{array}$ & $\begin{array}{l}\text { 1. Sportolási szint } \\
\beta=0,425 * * * \\
2 . \text { Egyéni/csapat } \\
\text { sportág } \\
\beta=0,150 * * * \\
\text { 3. Edzésmennyiség } \\
\beta=0,178 * * * \\
4 . \text { Nem } \\
\beta=-0,086 *\end{array}$ \\
\hline $\begin{array}{l}\text { Modell } \\
\text { jellemzői }\end{array}$ & $\mathrm{R}_{2}=0,240 * * *$ & $\mathrm{R}_{2}=0,257 * * *$ & $\mathrm{R}_{2}=0,219 * * *$ & $\mathrm{R}_{2}=0,399 * * *$ \\
\hline Kizárt változók & $\begin{array}{l}\text { osztály, sporttagozat, } \\
\text { mióta sportolsz, } \\
\text { egyéni/csapat sporttág }\end{array}$ & $\begin{array}{l}\text { nem, kor, osztály, } \\
\text { anyagi helyzet, mióta } \\
\text { sportolsz, } \\
\text { edzésmennyiség } \\
\text { egyéni/csapat } \\
\text { sporttág }\end{array}$ & $\begin{array}{l}\text { nem, kor, } \\
\text { sporttagozat, mióta } \\
\text { sportolsz, } \\
\text { egyéni/csapat } \\
\text { sporttág }\end{array}$ & $\begin{array}{l}\text { kor, osztály, } \\
\text { sporttagozat, anyagi } \\
\text { helyzet, mióta } \\
\text { sportolsz, }\end{array}$ \\
\hline
\end{tabular}




\subsubsection{Megbeszélés}

A fejezetben arra kerestem a választ, hogy a sport-elköteleződés modellre hogyan hatnak a különböző szociodemográfiai adatok és a sportolási szokásokkal kapcsolatos változók. Az elköteleződés típusok vizsgálatával kapcsolatban azt találtam, hogy az edzésmennyiség és a sportolási szint erösítik a lelkes elkötelezödést, azaz minél többet és minél magasabb szinten sportol valaki, annál inkább lesz elkötelezett a sportága iránt. Hasonló megállapításra jutottak Casper és munkatársai (2007) is, akik teniszezőknél vizsgálták, hogy az edzés gyakorisága milyen hatással van a teniszezők elköteleződésére. A vizsgálatból az is látszik, hogy a kor fordítottan arányos az elköteleződéssel, azaz minél idősebb valaki, annál kevésbe lesz motivált a rendszeres sportolás irányába. Sajnos ezt az állítást már hazai tanulmányok is igazolták (pl.: Szemes, Harsányi és Tóth, 2016). Csakúgy, mint azt, hogy a férfiak többet sportolnak és motiváltabbak, mint a nők (Olds és mtsai, 2009). Eredményeim azt is igazolták, hogy a lányok kevésbé elkötelezettek, mint a fiúk. Ezek az eredmények elég gyakoriak más motivációs kutatások terén is.

A vizsgálat második részében a sport-elköteleződés kérdőív azon részét elemeztem, mely az egyéni szintü forrásokat tartalmazza (értékes lehetöségek, sportélvezet, törekvés a fejlödésre - képesség, egyéb prioritások, személyes befektetések - mennyiség, személyes befektetések - veszteség). Az eredményekböl az látszik, hogy csakúgy, mint az elköteleződés típusoknál, itt is az edzésmennyiség és a sportolási szint voltak a leginkább pozitív tényezői az egyéni szintü forrásoknak, tehát ha többet edz, és magasabb szinten versenyez egy sportoló, az összefügg a motivációval. A két elem megjelenése azért lehet ilyen gyakori, mert a mintámban szereplő sportolók a versenyzést és az edzéseket, olyan lehetőségeknek élik meg, amely segítheti őket, hogy képességük szerint fejlődjenek, és az így befektetett forrásaikat (legyen az anyagi vagy időbeli befektetés) megbecsüljék. Érdekesség, hogy az értékes lehetőségeknél megjelent az iskolai osztály, mint változó, méghozzá negatív elöjellel. Ez arra enged következtetni, hogy a sportolóknak tanulmányuk előrehaladtával egyre kevesebb lehetőségük van sportolni. Ennek feltehetőleg a több elfoglaltságuk és másfajta kötelezettségük lehet az oka. Erre a megállapításra jutottak korábbi tanulmányok is (Scanlan és mtsai, 2009). A két személyes befektetés alskával kapott összefüggés a korral is erre enged következtetni. A személyes befektetések - mennyiség forrásánál már megjelenik a „mióta sportolsz?” változó. Ennek befolyásoló hatása egyáltalán nem meglepő, hiszen már találkozhattunk más kutatásokban is 
azzal a megállapítással, hogy aki régebb óta sportol, az több energiát is fektetett már a sportágába, és így nehezebben hagyja azt abba (Wilson és mtsai, 2004).

Elemzésem utolsó részében a közösségi szintü forrásokat vizsgáltam (közösségi kényszer, közösségi támogatás - érzelmi, közösségi támogatás-informális, törekvés a fejlödésreközösség). Ide azok a források kerültek, melyeket a közösség befolyásol, akár közösségi támogatás, akár nyomás formájában. Csakúgy, mint eddig, itt is elökelő helyet foglal el a befolyásoló tényezők sorában a sportolási szint és az edzésmennyiség. Ugyanakkor fontos megjegyezni, hogy mind a négy vizsgált alskálánál ez a leginkább befolyásoló tényező. Az eredmény azzal lehet összefüggésben, hogy a magasabb szinten versenyző sportolók inkább az őket körülvevőknek akarnak megfelelni vagy le akarják győzni a másikat, így emelkedve ki a többiek közül. Az alskálákat befolyásoló tényezők közül a nem, a kor és az iskolai osztály, mint változók hasonló eredményt mutatnak a már vizsgált változókkal. A közösségi kényszernél és a közösségi támogatás - informálisnál megjelenik az anyagi helyzet. Ez két megállapításra enged következtetni. Az egyik, hogy az az anyagi támogatás, amelyet az egyén kaphat, pozitívan befolyásolja az informális támogatást, másrészt pedig az ilyen támogatás megjelenhet egyfajta kényszerként is. Egy érdekes eredményt is találtunk a vizsgálatban, az érzelmi támogatás jobban jellemző a nem sporttagozatos diákokra. Ez talán azzal lehet összefüggésben, hogy a nem sporttagozatos sportolók számára a versengés mellett fontos a társak elismerése is. A törekvés a fejlődés - közösség forrásnál a sportágtípus az egyik pozitív tényező. Ezt az elemet a sportolási szint mellett a csapatsportág képviselői erősítik leginkább.

Összefoglalásképpen elmondható, hogy a felállított hipotézisem igazolódni látszik, ugyanis a sport iránti elköteleződést a szociodemográfiai és a sportolási szokások határozottan befolyásolják (H4). Úgy tünik, hogy a magasabb sportolási szint és a nagyobb edzésmennyiség a lelkesen elkötelezett sportolókra jellemző. Sajnos a nemmel és korral kapcsolatos feltételezéseim megegyeznek a szakirodalomban már feltártakkal, azaz a fiúk jobban elkötelezettek, mint a lányok, és a kor elörehaladtával a sportolási motiváció csökken, miután egyre több egyéb elfoglaltság jelenik meg a serdülőknél (Szemes és mtsai, 2016; Olds és mtsai, 2009). Csakúgy, mint számtalan esetben, az anyagi helyzet is befolyásolja a sportolást, ami egyes sportágaknál a magas költségigényben nyilvánul meg, másrészt viszont az anyagi támogatás kötelezettséget is ró az egyén felé. Láthatjuk azt is, hogy a csapatsportolóknál fontos 
a másik legyőzése, mely egyáltalán nem meglepő eredmény. A nem sporttagozatos sportolóknál viszont nemcsak a versenyzés, hanem a társak érzelmi támogatása is fontos szempont.

A fejezetben igyekeztem megválaszolni a sport iránti elköteleződés és a sportolási szokások, valamint a szociodemográfiai adatok kapcsolatát. Ugyanakkor mivel egy összetett jelenségről van szó a jövőben célszerủ újabb változókkal bővíteni az ilyenfajta kutatást.

\subsubsection{A sport iránti elköteleződés összehasonlítása a különböző sportágak képviselői között}

A fejezetben bemutatom a sport-elköteleződés modell különbségeit különböző sportágak körében különös tekintettel a labdajátékokra. Miután az előző fejezetben hangsúlyos szerepe volt a különböző szinten és különböző sportágakban versenyző sportolóknak ezért úgy döntöttem, hogy a szintek különbségeit tovább elemzem és megvizsgálom a különbségeiket is. A vizsgálatomat az első adatgyüjtés sport-elköteleződés kérdőív-2 és a sportolási szokásokra adott válaszok $(\mathrm{n}=526)$ alapján végeztem el.

\subsubsection{Statisztikai módszer}

$\mathrm{Az}$ adatok feldolgozását SPSS programmal végeztem. Az elemzés során a sport iránti elköteleződés típusainak és forrásainak sportág, iskolatípus, versenyzés és a sport jellege (csapat/egyéni) szerinti összehasonlítását kétmintás t-próbával, valamint egyszempontos varianciaelemzéssel végeztem el.

\subsubsection{Eredmények}

Az adatok elemzését a sport iránti elköteleződés típusok vizsgálatával kezdtem, ahol a skálák átlagértékeit vettem alapul. A kapott eredményeim szerint a csapatsportágat üzők szignifikánsan magasabb értékkel rendelkeznek a lelkes elkötelezödés tekintetében, mint az egyéni sportolók ( $\mathrm{p}<0,01)$. Az erőltetett elkötelezödésnél nem látható hasonló eltérés.

Az előzekben láthattuk, hogy a sportolási szint magas magyarázó erővel bír a sportelköteleződés modellben, ezért megvizsgáltam, hogy a szintek között található-e jelentős eltérés. Mindkét elköteleződés típus szignifikáns eredményt mutatott. A táblázatból látszik, hogy a sportolási szinttel egyenes arányban nő a lelkes elkötelezödés értéke $(\mathrm{p}<0,01)$. Az eröltetett 
elkötelezödés nem mutat ilyen tendenciát, itt az országos szinten versenyzők érték el a legmagasabb pontokat $(\mathrm{p}<0,05)$.

Kíváncsi voltam a mintánk legnépszerübb csapatsportágainak különbségeire is. A csoportok csak a lelkes elkötelezödés esetében különböztek szignifikánsan ( $\mathrm{p}<0,05)$. Itt a labdarúgás ért el kiemelkedően magas pontokat, majd ezt a kosárlabda és a vízilabda követte hasonló pontszámokkal. Az erőltetett elköteleződés ugyan nem hozott szignifikáns eredményeket a csapatjátékok összehasonlításánál, de itt is megfigyelhető, hogy a vízilabda és a kosárlabda hasonló eredménnyel rendelkezik (12. táblázat).

12. táblázat. A sport elkötelezödés típusainak összehasonlítása sportolási jellemzök tükrében

\begin{tabular}{lcc}
\hline Sport típusa & $\begin{array}{c}\text { Lelkes elköteleződés } \\
\text { Átlag (szórás) }\end{array}$ & $\begin{array}{c}\text { Erőltetett elköteleződés } \\
\text { Átlag (szórás) }\end{array}$ \\
\hline Egyéni & $24,19(5,79)$ & $11,61(4,36)$ \\
Csapat & $25,73(5,29)$ & $11,62(4,32)$ \\
\hline t-érték & $-3,18$ & $-0,34$ \\
szignifikancia & $\mathbf{p}<\mathbf{0 , 0 1}$ & $\mathrm{p}>0,05$ \\
\hline Versenyzés szintje & $26,81(4,41)$ & $11,61(4,41)$ \\
Nemzetközi szint & $25,50(4,85)$ & $12,29(4,42)$ \\
Országos szint & $23,06(6,73)$ & $10,78(4,30)$ \\
Helyi, megyei szint & $20,43(6,73)$ & $10,58(3,67)$ \\
Hobbi szint & 34,50 & 3,76 \\
\hline F-érték & $\mathbf{p}<\mathbf{0 , 0 1}$ & $\mathbf{p}<\mathbf{0 , 0 5}$ \\
Szignifikancia & & $11,53(4,59)$ \\
\hline Csapatsportágak & $27,20(3,59)$ & $12,33(4,63)$ \\
Labdarúgás & $25,57(6,01)$ & $11,40(4,00)$ \\
Kosárlabda & $24,16(6,16)$ & $12,62(4,19)$ \\
Kézilabda & $25,79(5,08)$ & 1,03 \\
Vizilabda & 3,46 & $\mathrm{p}>0,05$ \\
\hline F-érték & $\mathbf{p}<\mathbf{0 , 0 5}$ & \\
Szignifikancia & &
\end{tabular}

A vizsgálat következő részében a sport iránti elköteleződés egyéni szintü forrásait elemeztem, hasonlóképpen az előzőekhez. A 13. táblázatban az látszik, hogy a csapatsportágak képviselői jelentősen magasabb pontszámokat értek el a sportélvezet, értékes lehetöségek, személyes befektetések - veszteség, személyes befektetések - mennyiség és a törekvés a fejlödés képesség változók tekintetében $(\mathrm{p}<0,05)$. Nem mutat ugyan szignifikáns eredményt, de érdemes megjegyezni, hogy az egyéb prioritások változó az egyéni sportolóknál magasabb. 
A sportolási szint elemzésénél valamennyi változó szignifikáns értéket mutatott. A sportélvezet alskála tekintetében a szignifikancia ellenére is kis különbségek láthatóak a csoportok között, azonban a hobbi szinten sportolóknál látható a legalacsonyabb érték. Az egyéb prioritásoknál azt tapasztaltam, hogy amint csökken a sportolási szint, úgy nő a változó értéke. Az értékes lehetöségek, személyes befektetések - veszteség, személyes befektetések-mennyiség és a törekvés a fejlödés - képesség alskálák esetében a nemzetközi szinten versenyzők különböztek szignifikánsan a többi csoporttól.

A csapatsportok összehasonlításánál három szignifikáns kapcsolatot találtam. A csoportok között különbség látható a sportélvezet, a személyes befektetések - mennyiség és a törekvés a fejlödés - képesség változók terén ( $\mathrm{p}<0,05)$. A sportélvezet és a törekvés a fejlödésre változóknál a labdarúgók emelkednek ki, míg a személyes befektetések - mennyiségi változónál, ha még kicsivel is, de a vízilabdás serdülők fektetik legtöbbet a sportágukba. 
13. táblázat. A sport elkötelezödés egyéni szintü forrásainak összehasonlítása sportolási jellemzök tükrében

\begin{tabular}{|c|c|c|c|c|c|c|}
\hline Sport típusa & $\begin{array}{c}\text { Sportélvezet } \\
\text { Átlag } \\
\text { (szórás) }\end{array}$ & $\begin{array}{c}\text { Értékes } \\
\text { lehetőségek } \\
\text { Átlag (szórás) }\end{array}$ & $\begin{array}{c}\text { Egyéb } \\
\text { prioritások } \\
\text { Átlag (szórás) }\end{array}$ & $\begin{array}{c}\text { Személyes } \\
\text { befektetések- } \\
\text { veszteség } \\
\text { Átlag (szórás) }\end{array}$ & $\begin{array}{c}\text { Személyes } \\
\text { befektetések- } \\
\text { mennyiség } \\
\text { Átlag (szórás) }\end{array}$ & $\begin{array}{c}\text { Törekvés a } \\
\text { fejlődésre- } \\
\text { képesség } \\
\text { Átlag (szórás) }\end{array}$ \\
\hline Egyéni & $22,12(3,47)$ & $15,05(4,39)$ & $13,10(4,80)$ & $17,45(5,28)$ & $16,57(3,60)$ & $25,51(4,69)$ \\
\hline Csapat & $23,03(3,12)$ & $16,46(3,70)$ & $12,50(4,32)$ & $18,37(5,24)$ & $17,82(3,18)$ & $26,54(4,24)$ \\
\hline $\begin{array}{l}\text { t-érték } \\
\text { szignifikancia }\end{array}$ & $\begin{array}{c}-3,17 \\
\mathbf{p}<\mathbf{0 , 0 1}\end{array}$ & $\begin{array}{c}-5,10 \\
\mathbf{p}<\mathbf{0 , 0 1}\end{array}$ & $\begin{array}{c}1,63 \\
p>0,05\end{array}$ & $\begin{array}{c}-1,96 \\
\mathbf{p}<\mathbf{0 , 0 5}\end{array}$ & $\begin{array}{c}-3,82 \\
\mathbf{p}<\mathbf{0 , 0 1}\end{array}$ & $\begin{array}{c}-2,82 \\
\mathbf{p}<\mathbf{0 , 0 5}\end{array}$ \\
\hline \multicolumn{7}{|l|}{ Sportolás szintje } \\
\hline Nemzetközi szint & $22,84(3,15)$ & $17,66(2,62)$ & $12,28(4,39)$ & $19,62(4,46)$ & $18,84(1,84)$ & $27,51(3,30)$ \\
\hline Országos szint & $22,71(3,38)$ & $16,56(3,35)$ & $12,63(4,29)$ & $18,51(4,83)$ & $17,95(2,47)$ & $26,44(3,74)$ \\
\hline Helyi, megyei szint & $22,71(3,06)$ & $14,38(4,20)$ & $13,40(4,52)$ & $15,14(5,00)$ & $15,38(3,68)$ & $24,25(4,61)$ \\
\hline Hobbi szint & $21,61(3,68)$ & $10,30(3,65)$ & $14,05(5,49)$ & $14,06(5,69)$ & $12,75(3,84)$ & $22,58(6,06)$ \\
\hline $\begin{array}{l}\text { F-érték } \\
\text { Szignifikancia }\end{array}$ & $\begin{array}{c}3,00 \\
\mathbf{p}<\mathbf{0 , 0 5} \\
\end{array}$ & $\begin{array}{c}113,93 \\
\mathbf{p}<\mathbf{0 , 0 1} \\
\end{array}$ & $\begin{array}{c}3,42 \\
\mathbf{p}<\mathbf{0 , 0 5} \\
\end{array}$ & $\begin{array}{c}32.94 \\
\mathbf{p}<\mathbf{0 , 0 1} \\
\end{array}$ & $\begin{array}{c}119,38 \\
\mathbf{p}<\mathbf{0 , 0 1} \\
\end{array}$ & $\begin{array}{c}32,53 \\
\mathbf{p}<\mathbf{0 , 0 1} \\
\end{array}$ \\
\hline \multicolumn{7}{|l|}{ Csapatsportágak } \\
\hline Labdarúgás & $24,13(1,46)$ & $17,04(2,95)$ & $12,14(4,15)$ & $18,81(4,72)$ & $18,47(2,05)$ & $27,73(2,82)$ \\
\hline Kosárlabda & $22,88(2,92)$ & $15,97(4,64)$ & $13,06(4,89)$ & $17,90(5,84)$ & $17,30(4,03)$ & $25,68(5,24)$ \\
\hline Kézilabda & $22,45(3,42)$ & $16,14(3,78)$ & $11,73(4,64)$ & $18,20(4,83)$ & $17,21(3,57)$ & $26,13(4,63)$ \\
\hline Vizilabda & $21,74(4,31)$ & $16,80(3,53)$ & $12,71(4,35)$ & $19,38(5,02)$ & $18,55(2,01)$ & $26,42(3,96)$ \\
\hline F-érték & 7,29 & 1,04 & 0,76 & 0,81 & 3,46 & 2,78 \\
\hline Szignifikancia & $\mathrm{p}<0,01$ & $\mathrm{p}>0,05$ & $p>0,05$ & $p>0,05$ & $\mathrm{p}<0,05$ & $\mathrm{p}<0,05$ \\
\hline
\end{tabular}


Az eredmények elemzését a sport-elköteleződés közösségi szintü forrásainak összehasonlításával zártam. Mivel közösségi változókról van szó, ezért nem meglepő, hogy a csapatsportolók szignifikánsan magasabb pontot értek el a közösségi kényszer és a törekvés a fejlödésre-közösség változók tekintetében ( $\mathrm{p}<0,01)$, de az érzelmi és informális típusú közösségi támogatás is a csapatsportolóknál volt magasabb (14. táblázat).

A különböző sportolási szinten sportolóknál is valamennyi közösségi változó szignifikáns eredményt mutatott. A táblázatból kiolvasható, hogy a sportolási szint emelkedésével nőnek az alskálákra adott pontok értékei is.

A törekvés a fejlödésre - közösség változó hozott egyedül szignifikáns eredményt a csapatsportok összehasonlításánál. Itt azt láthatjuk, hogy leginkább a labdarúgók igyekeznek legyőzni ellenfelüket.

14. táblázat. A sport elkötelezödés közösségi szintü forrásainak összehasonlítása sportolási jellemzök tükrében

\begin{tabular}{lcccc}
\hline Sport típusa & $\begin{array}{c}\text { Közösségi } \\
\text { kényszer } \\
\text { Átlag } \\
\text { szórás })\end{array}$ & $\begin{array}{c}\text { Közösségi } \\
\text { támogatás- } \\
\text { érzelmi } \\
\text { Átlag (szórás) }\end{array}$ & $\begin{array}{c}\text { Közösségi } \\
\text { támogatás- } \\
\text { informális } \\
\text { Átlag (szórás) }\end{array}$ & $\begin{array}{c}\text { Törekvés a } \\
\text { fejlödésre- } \\
\text { közösség } \\
\text { Átlag (szórás) }\end{array}$ \\
\hline Egyéni & $12,51(4,47)$ & $15,50(4,03)$ & $17,82(4,55)$ & $19,17(4,54)$ \\
Csapat & $13,41(4,20)$ & $16,02(3,52)$ & $18,25(4,64)$ & $21,72(3,51)$ \\
\hline t-érték & $-2,66$ & $-1,63$ & $-1,49$ & 7,00 \\
szignifikancia & $\mathbf{p}<\mathbf{0 , 0 5}$ & $\mathrm{p}>0,05$ & $\mathrm{p}>0,05$ & $\mathbf{p}<\mathbf{0 , 0 1}$ \\
\hline Sportolás szintje & & & & \\
Nemzetközi szint & $14,36(3,74)$ & $17,21(2,97)$ & $19,57(3,83)$ & $22,14(2,80)$ \\
Országos szint & $13,64(3,87)$ & $16,13(3,29)$ & $18,53(4,13)$ & $21,32(3,19)$ \\
Helyi, megyei szint & $11,23(4,14)$ & $14,83(3,40)$ & $16,20(4,65)$ & $19,71(3,58)$ \\
Hobbi szint & $9,27(4,45)$ & $12,07(4,22)$ & $14,40(5,00)$ & $15,07(4,98)$ \\
\hline F-érték & 38,95 & 50,12 & 34,59 & 91,79 \\
Szignifikancia & $\mathbf{p}<\mathbf{0 , 0 1}$ & $\mathbf{p}<\mathbf{0 , 0 1}$ & $\mathbf{p}<\mathbf{0 , 0 1}$ & $\mathbf{p}<\mathbf{0 , 0 1}$ \\
\hline Csapatsportágak & & & & \\
Labdarúgás & $13,72(3,76)$ & $16,35(3,44)$ & $19,03(4,17)$ & $22,82(2,45)$ \\
Kosárlabda & $13,15(5,51)$ & $16,09(3,43)$ & $18,56(4,56)$ & $20,42(4,00)$ \\
Kézilabda & $13,21(3,73)$ & $17,00(3,02)$ & $18,36(4,36)$ & $21,02(3,66)$ \\
Vizilabda & $14,19(3,44)$ & $15,54(3,70)$ & $18,06(4,32)$ & $21,79(3,33)$ \\
\hline F-érték & 0,79 & 1,61 & 0,64 & 5,37 \\
Szignifikancia & $\mathrm{p}>0,05$ & $\mathrm{p}>0,05$ & $\mathrm{p}>0,05$ & $\mathbf{p}<\mathbf{0 , 0 1}$ \\
\hline
\end{tabular}




\subsubsection{Megbeszélés}

A fejezetben a sport iránti elköteleződés különbségeit vizsgáltam különböző szinten sportolók és különböző sportágat űzők között, így megvizsgáltam, hogy az egyéni és csapatsportágak képviselői között milyen eltérések tapasztalhatók, továbbá arra is kíváncsi voltam, hogy a magyar sportoló serdülőkre igaz-e az az állítás, miszerint minél magasabb szinten sportol valaki, annál motiváltabb lesz (Domínguez-Escribano és mtsai, 2015; Ong, 2017). Végezetül megvizsgáltam a minta legnépszerübb csapatsportágainak képviselöit is azzal kapcsolatban, hogy milyen eltérések tapasztalhatóak a labdarúgók, kézilabdázók, kosárlabdázók és a vízilabdázók sport iránti elköteleződésében.

A vizsgálatban számos szignifikáns eltérést találtam az egyéni és a csapatsportolók között. A csapatsportágak képviselői szignifikánsan magasabb pontszámokat értek el a lelkes elkötelezödés, sportélvezet, értékes lehetöségek, személyes befektetések-veszteség, személyes befektetések-mennyiség, törekvés a fejlödésre-képesség, törekvés a fejlödésre-közösség és a közösségi kényszer változók terén. Érdekes módon az egyéni sportágakat űzők sehol nem értek el számottevően magasabb értékeket. Az eredményeimből látszik, hogy a csapatsportolók nem csak a közösségi változókban értek el szignifikánsan nagyobb eredményt és az is kiderült, hogy az egyéni sportágat üzők nem emelkedtek ki az egyéni változóknál. A szakirodalomban számos esetet találunk, ahol azt bizonyították, hogy a csapatsportágak képviselői jobban teljesítenek, és jobb mentális attitüddel rendelkeznek, mint az egyéni sportot űző társaik (Kajbafnezhad, Ahadi, Heidarie, Askari és Enayati, 2011). Ennek okai talán a sportpszichológiában keresendők. A csapatsportágakban az egyént erőteljesebben motiválhatja a győzelem és az elérendő cél, mint az egyéni sportágakban, hiszen a csapatsportágakban komoly motivációs erővel bírhat a „csapatszellem” adta plusz. Patterson és munkatársai (2005) kutatása szerint a párbeszéd és az összetartozás megléte jobb teljesítményt hozhat ki csapatszinten. Ezért mintánkban talán az összetartozás lehet a kulcsa a sport iránti elköteleződés legkülönbözőbb dimenzióinak megmutatkozásában, akár az egyéni szintü (pl. törekvés a fejlödésre - képesség), akár a közösségi szintü (pl. törekvés a fejlödésre - közösség) forrásokat tekintjük. Az összetartozás érzésének a hiánya a lemorzsolódással is kapcsolatban lehet. Az eredményeink szerint az egyéni sportágak képviselői - akik nem tartoznak csapatokhoz - enyhén, de a szignifikanciát el nem érő mértékben magasabb pontszámokat értek el az egyéb prioritások terén, azaz ők könnyebben 
elcsábulnak más időtöltés felé. Ahogyan láthattuk, mintánk különbségei a csapatsportágak képviselői javára nemcsak extrinzik, hanem intrinzik elemeket is tartalmaznak. Ennek okát az egyén intrinzik motiváltságán túl a csapatsportágakra jellemző egyéni képzésekben látjuk (Hawkins, Hulse, Wilkinson, Hodgson és Gibson, 2001).

A vizsgálat másik szempontja a sportolási szintekre vonatkozott: itt arra voltam kíváncsi, hogy a sport iránti elköteleződés miképpen változik a különböző sportolási szinteken. A vizsgálat valamennyi változóval szignifikáns különbségeket mutatott ki. Összhangban más kutatásokkal és előző vizsgálatommal a különbség itt is igazolódott. A mintában is az látszik, hogy minél magasabb szinten sportol valaki, úgy nő a motivációja (Domínguez-Escribano és mtsai, 2015; Ong, 2017). Tény, hogy ha valaki elköteleződik egy sportág mellett az nem csak egy sportág iránti szeretetből származhat. Eredményeimből is kitünik, hogy az eröltetett elkötelezödés szignifikánsan eltér a sportolási szintek között. Ezt az eredményt azzal magyarázhatjuk, hogy a minél magasabb szinteken versenyzőknél a külső hatások is egyre nagyobb szerepet játszhatnak (Chantal és mtsai, 1996; Scanlan és mtsai, 2009). Ilyen hatások lehetnek a sportoló irányába a szülőktől, edzőktől érkező nyomás vagy a már befektetett energia és idő is egyfajta kényszert jelenthet a sportolónak. A közösségi normák és támogatások is kötelezettséget jelenthetnek. Casper és Andrew (2008) teniszezőkön végzet vizsgálatukban azt találták, hogy ahogyan nő a szociális nyomás, úgy válik egyre inkább kényszeredetté a sportolás is. Ez a tendencia ismerhető fel saját eredményeimben is. Ha megnézzük a közösségi szintű forrásokat, mindegyik jelentősége megnő a sportolási szint emelkedésével. Érdemes még foglalkoznunk az egyéb prioritások változóval, ahol megfordul az eredmény, és azt tapasztalhatjuk, hogy a hobbi sportolóknál jóval jellemzőbbek az egyéb elfoglaltságok, mint például a nemzetközi szinten versenyző atlétáknál. Scanlan és munkatársai (2009) a sport alternatíváit vizsgálva arra jutottak, hogy a magas szinten sportolók nem tudják elképzelni, hogy a sporton kívül mást is csináljanak. Ez az eredmény középiskolás sportolóknál változhat, mivel számukra már komoly szerepet kaphat a tanulás, mint alternatíva. Ezt az állítást a mintában a tagozatok összehasonlítása is alátámasztja.

A csapatsportágak típusainak vizsgálatával kevés tanulmány foglalkozik. A sport iránti elköteleződés terén nem is készült még hasonló munka. Eredményeinkben a lelkes elkötelezödés, sportélvezet, személyes befektetések-mennyiség, törekvés a fejlödésre-képesség, valamint a törekvés a fejlödésre - közösség terén találtunk szignifikáns eltéréseket. A legtöbb 
helyen a labdarúgás érte el a legnagyobb értéket, mely összhangban van más kutatásokkal is (Géczi és mtsai, 2009). Jégkorongozókat, vízilabdázókat, röplabdázókat és labdarúgókat vizsgálva azt tapasztalták, hogy a labdarúgók magasabb intrinzik motivációval és alacsonyabb amotivációval rendelkeznek. Csáki és mtsai (2017) egy másik vizsgálatban ennek ellenkezőjét találták. Ök arra a megállapításra jutottak, hogy az extrinzik motiváció nagyobb szerepet tölt be a játékosoknál. A kutatásomban mindkét állítás megállja a helyét, hiszen az eredményemben mind az intrinzik (pl.: sportélvezet), mind az extrinzik (pl.: törekvés a fejlödésre - közösség) elemek fontos szerepet töltenek be.

A labdarúgás kiemelkedett a többi csapatsportág közül, melynek talán az egyik lehetséges magyarázata, hogy az elmúlt évek sportági fejlesztései bár valamennyi sportágra hatással voltak, de a labdarúgásban történt igazán ugrásszerü infrastrukturális fejlődés. Továbbá a labdarúgó akadémiák elterjedése arra sarkall sok gyerekeket, hogy minél inkább elköteleződjenek a sportág iránt. A serdülö labdarúgók az akadémiákon ma már profi körülmények között, remek szakmai stábbal fejlődhetnek. Az ilyen intézményekben a szakmai felkészítés mellett, a labdarúgók tanulmányaira is odafigyelnek, így segítve az esetleges lemorzsolódásuk utáni civil életet (Rábai, 2016). A vizsgálatban a szignifikáns változók alapján egy olyan labdarúgó képe alakulhat ki szemünk előtt, aki szereti sportágát, sok energiát fektet bele, és célja a saját maga fejlesztése, valamint a győzelem átélése. A személyes befektetések mennyiségi változónál kevéssel ugyan, de a vízilabda kapta a legnagyobb érteket. Sajnos a vízilabdázók motivációs hétteréről keveset tudunk, mivel igen kevés kutatás készült ebben a témában (pl.: Géczi és mtsai, 2009). Ez az eredmény talán annak köszönhető, hogy a vízilabdázók eleinte éveken át időt, energiát és anyagiakat nem kímélve igen sokat fektetnek az úszásba, majd ezt követően térnek át a tulajdonképpeni sportáguk gyakorlásába, ami jelentős és hosszú távú elkötelezettséget igényel a részükről.

Összefoglalásképpen elmondható, hogy a szakirodalommal megegyező eredményeket kaptam és mélyebb betekintést kaphatunk, a sportolási szokások és sport-elköteleződés modell kapcsolatára. Az eredményeim megerősítettek a hipotézisemben, hiszen bizonyítást nyert, hogy a sportágak és a sportolási szint hatással vannak a sport-elköteleződés modell változóira (H2). A vizsgálatomból kiderült, hogy a csapatsportágak képviselői számos faktorban térnek el az egyéni sportolóktól, mely faktorok nemcsak extrinzik, hanem intrinzik jellegü elemeket is tartalmaznak. A regresszió-elemzés után az ANOVA elemzés is megerősítette, hogy minél 
magasabb szinten versenyezik valaki, annál elkötelezetebb lesz a folytatásra, mivel az országos és nemzetközi szinten versenyző serdülők a legelkötelezetebbek. A labdarugók kiemelkedése a csapatsportok közül egy érdekes eredmény, melyről a szakirodalomban is eltérések láthatók (pl.: Géczi és mtsai, 2009).

\subsection{A motiváció és az identitás szerepe a sport-elköteleződés modellben}

A következő részben célom bemutatni a sport-elköteleződés modell kapcsolatát más motivációs megközelítésekkel. Igyekszem feltárni az öndeterminációs elmélet és a sportolói identitás sajátosságait mintámon, valamint összefüggéseit a sport-elköteleződés modellel. Célom, hogy kutatásom elején feltett harmadik kérdéskörre és hipotéziseimre $\left(\mathrm{H}_{3}-\mathrm{H}_{6}\right)$ megfelelő választ tudjak adni, valamint szeretném, ha az olvasó képet kapna a modell helyzetéről más motivációs elméletekkel összefüggésben.

\subsubsection{A sport-elköteleződés modell és az öndeterminációs elmélet kapcsolata}

Vizsgálatomban a sport-elköteleződés modell összefüggéseit vizsgáltam a széles körben használt öndeterminációs elmélettel. Az eredményeimhez a 2. vizsgálatban szerzet adatokat (n = 356) használtam fel és a sport-elköteleződés-2 kérdöív magyar változatát, valamint a sportmotivációs skálát vontam be az elemzésekbe.

\subsubsection{Statisztikai módszer}

Többváltozós lineáris regressziót alkalmaztam „stepwise” módszerrel, hogy megtudjam milyen változók magyarázzák a sport-elköteleződés modellt és az öndeterminációs elmélet kapcsolatát. Ehhez először megvizsgáltam a kétféle elköteleződés típust, mint függő és a sportmotiváció alskáláit, mint független változókat. Majd megvizsgáltam, hogy az elköteleződés források, hogyan magyarázzák az öndeterminációt, így regresszió elemzéseben az öndetermináció változóit, mint függő, a sport-elköteleződés alskáláit, mint független változókat elemeztem. A szignifikancia elfogadott szintje 0,05 százalék volt. 


\subsubsection{Eredmények}

Vizsgálatom első részében megnéztem, hogy a sportmotivációs skála, hogyan magyarázza a kétféle elköteleződés típust. A „stepwise” regresszió a lelkes elköteleződés a variancia 62 százalékát magyarázta és a végső modell szerint a lelkes elkötelezödést az intrinzik motiváció ( $\beta$ =0,22) magyarázta első helyen, majd ezt követte az integrált szabályozás $(\beta=0,21)$, amotiváció $(\beta=-0,12)$ és az introjektált szabályozás $(\beta=0,12)$. Az eröltetett elköteleződést a variancia 28 százalékával magyarázták szignifikánsan a kapott változók, melyek a következők voltak: amotiváció $(\beta=0,15)$, külső szabályozás $(\beta=0,19)$ intrinzik motiváció $(\beta=-0,10)$.

Az elemzésem következő részében megvizsgáltam, hogy a sport elköteleződés forrásai, hogyan magyarázzák a sportmotivációt. Az amotivációt $\left(\mathrm{R}_{2}=0,35\right)$ a sportélvezet $(\beta=-0.52)$, személyes befektetések - veszteség $(\beta=0,38)$ és az egyéb prioritások $(\beta=0,39)$ magyarázták. A külső szabályozásra $\left(\mathrm{R}_{2}=0,27\right)$ szignifikánsan hat a közösségi kényszer $(\beta=0,41)$, sportélvezet $(\beta=-0,23)$, valamint a közösségi támogatás - informális $(\beta=0,29)$. Tovább haladva az öndeterminációs kontinuumon az introjektált szabályozást $\left(\mathrm{R}_{2}=0,32\right)$ két változó magyarázta, név szerint: törekvés a fejlödésre - képesség $(\beta=0,27)$ és a személyes befektetések - veszteség $(\beta=0,19)$. Az identifikált szabályozást $\left(\mathrm{R}_{2}=0,47\right)$ a törekvés a fejlödésre-képesség $(\beta=0,39)$, értékes lehetöségek $(\beta=0,22)$ és a személyes befektetések - veszteség magyarázták $(\beta=0,24)$. Az utolsó extrinzik elemet az integrált szabályozást $\left(\mathrm{R}_{2}=0,58\right)$ elsőként az értékes lehetöségek $(\beta=0,24)$ magyarázta, majd a törekvés a fejlödésre - képesség követte $(\beta=0,24)$, valamint a személyes befektetések - veszteség $(\beta=0,14)$ és a közösségi támogatás - informális $(\beta=0,13)$ is szignifikáns magyarázó erővel bírt. Végezetül megnéztem az intrinzik motivációra ható változókat. A variancia 57 százalékában magyarázták a sport-elköteleződés elemei, melyek a következők voltak: törekvés a fejlődésre - képesség $(\beta=0,77)$, személyes befektetések veszteség $(\beta=0,42)$, sportélvezet $(\beta=0,37)$ közösségi támogatás - informális $(\beta=0,42)$.

Az eredmények összefoglalása érdekében ábrázoltam a sport-elköteleződés összefüggéseit az öndeterminációs kontinuumon (13. ábra). Az ábra jelöli a pozitív és negatív kapcsolatokat a standardizáld regressziós együtthatókkal, valamint a magyarázott variancia $\left(\mathrm{R}_{2}\right)$ értékeivel. 


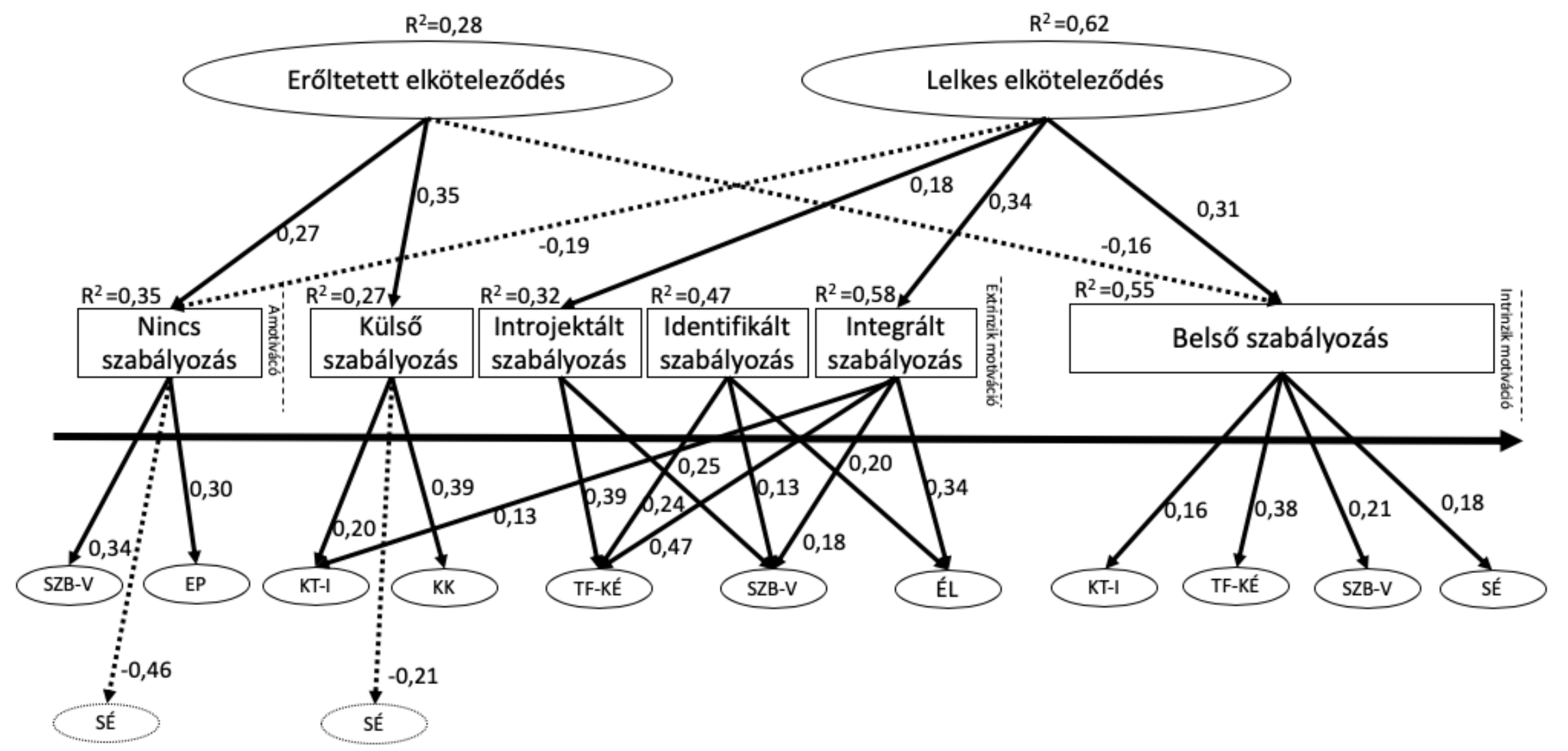

13. ábra. A sport-elkötelezödés Modell az öndeterminációs kontinuumon, a standardizáld regressziós együtthatókkal

Megjegyzés: SÉ= Sportélvezet; ÉL=Értékes lehetőségek; SZB-M=Személyes befektetések - mennyiség; SZB-V=Személyes befektetésesek - veszteség; EP=Egyéb prioritások; TF-KÉ=Törekvés a fejlődésre - képesség; KK=közösségi kényszer; KTÉ=Közösségi támogatás - érzelmi; KT-I=Közösségi támogatás - informális; 


\subsubsection{Megbeszélés}

A kutatással célom volt, hogy képet kapjunk a sport-elköteleződés modell és az öndeterminációs kontinuum kapcsolatáról. Az elemzések számos kapcsolatot kimutattak a két modell kapcsolatáról. Az eddigi tudásom alapján nem készült más hasonló vizsgálat ezelött.

Az első lépésben az elköteleződés típusok (lelkes, erőltetett) és sportmotivációs változók kapcsolatát tártam fel. Ahogy feltételeztem $\left(\mathrm{H}_{3}\right)$ az intrinzik motiváció (magas öndetermináció) pozitív eleme volt a lelkes elkötelezödésnek. Emellett az integrált és az introjektált szabályozás is szignifikánsan magyarázta a modellt. Az intrinzik motiváció kapcsolata az elköteleződéssel egyáltalán nem meglepő eredmény, hiszen számtalan kutatás bizonyította, hogy az öröm, az egyén döntése és a belső „drive” fontos elemei a lelkes elkötelezödésnek és az intrinzik motivációnak egyaránt (Pelletier és mtsai, 2013; Scanlan és mtsai, 2016). Ahogy említettem, az introjekció is szerepet játszik a lelkes elkötelezödésben. Ez talán annak köszönhető, hogy az introjektált szabályozásban megjelenik a lelkiismeret, azaz a büntudat és a szégyenérzet, ami inkább az erőltetett elköteleződésnek a forrása lenne, ám kutatások megmutatták, hogy az introjekció kapcsolatban áll a magasabb szinteken versenyzőkkel (Gillison, Osborn, Standage, és Skevington, 2009). Talán ez lehet eredményeink kulcsa is, hiszen az előző fejezetekben láthattuk, hogy a magas sportolási szint nagyobb lelkes elkötelezödést is eredményezhet. Az integrált szabályozás az extrinzik motiváció leginkább autonóm formája, amely leírható az egyén életcéljaival és szükségleteivel. A szakirodalom szerint az integrált szabályozás nagyban összefügg a lelkes elköteleződéssel (Scanlan és mtsai, 2016), valamint a sport-elköteleződés kutatások azt is megmutatták, hogy az egyéni teljesítés (törekvés a fejlödésre - képesség) az egyik legfontosabb forrása lehet a lelkes elkötelezödésnek (Scanlan és mtsai, 2016). A lelkes elköteleződés negatív kapcsolatot mutatott az amotivációval. Ez az eredmény megerösíti, hogy fordított, kapcsolat van a kétféle elköteleződés típus között (Scanlan és mtsai, 2003, 2009, 2016).

Az erőltetett elköteleződés és a sportmotiváció kapcsolatának eredményei a hipotézisemmel azonos eredményt mutattak (H3), ugyanis pozitív magyarázója volt az amotiváció és a külső szabályozás is (alacsony öndetermináció). Ennél az elemzésnél is láthattuk, hogy fordított kapcsolat áll fent az egyes sport-elköteleződés változók (pl.: sportélvezet) között, hiszen az intrinzik motiváció negatív magyarázója volt a modellnek. A mintában az eröltetett elkötelezödés a lelkes elkötelezödéssel ellentétben csupán az öndetermináció alacsony formáival volt kapcsolatban. Érdemes megjegyezni, hogy az 
amotiváció elsősorban, a kiégéssel és a lemorzsolódással áll kapcsolatban, a külső szabályozás pedig azokat az eseteket írják le, amelyekben a sportoló valamilyen külső hatás miatt sportol (pl.: anyagi jutalom a sportolásért). A külső jutalmak meglétére a motivációs kutatásokban elég vegyes képet mutatnak. Vannak kutatások, ahol elutasítják azokat, hiszen hosszú távon nem kifizetődők (pl.: Cameron, Banko és Pierce, 2005). A közelmúlt tanulmányai arra világítottak rá, hogy a külső jutalom növelheti a testmozgás belső motivációját (Cameron és mtsai, 2005). Az eredményeink alapján a belső motiváció mellet a külső motivációs tényezők is növelhetik az elköteleződést, de a mintámban nem a jutalmak játszák a főszerepet, hanem inkább az életcélok és szégyenérzet (pl.: szégyellem a testem és ezért mozgok, hogy jól nézzek ki.)

A vizsgálatom következő részében megvizsgáltam hogyan irhatóak le az öndeterminációs elmélet változói a sport-elköteleződés forrásaival. Az amotivációt három sport-elköteleződés változó magyarázta. Az előzetes feltételezésem és az előző eredményeim alapján az amotiváció pozitív kapcsolata az egyéb prioritásokkal és negatív kapcsolata a sportélvezettel egyáltalán nem meglepő. Ezt az eredményt korábbi sportelköteleződés kutatások is megerösítik, hiszen egyértelmüen bizonyított, hogy a sportélvezet pozitívan míg az alternatívák negatívan befolyásoljak a sport-elköteleződést (Scanlan és mtsai, 1993, 2009, 2016). Érdekesebb eredmény az amotiváció és a személyes befektetések - veszteség pozitív kapcsolata. A változó leginkább kötelezettséget róhat az egyénre, hiszen így nehezebben hagyják abba sportolást félvén, hogy az addig befektetett energia elvész (Scanlan és mtsai, 1993, 2009, 2016). Talán emiatt a kényszerből való sportolás miatt logikus, hogy ide került a változó, de ahogy láthattuk az eredményekben egy sokkal komplexebb elemről van szó, hiszen megjelenik az extrinzik és intrinzik motivációban egyaránt.

Empirikus kutatásom elején feltételeztem, hogy az alacsonyabb öndetermináció motiváció, így az extrinzik motiváció a kényszer, közösség, alternatívák és a befektetéseket, leíró változókkal áll kapcsolatban $\left(\mathrm{H}_{4}\right)$. A vizsgálat azt mutatta, hogy összesen hat változó áll kapcsolatban az extrinzik motivációval (sportélvezet; közösségi kényszer; közösségi támogatás - informális; törekvés a fejlödésre - képesség; személyes befektetések veszteség; értékes lehetőségek). A sportélvezet megjelenése a külső szabályozásban, mint negatív magyarázó tényező egyáltalán nem meglepő, hiszen korábbi kutatások is negatív kapcsolatot találtak a külső motivációval (Wilson és mtsai, 2004). A külső szabályozás közösségi változókkal is kapcsolatban állt. Ez összehangban van a hipotéziseinkkel miszerint az extrinzik motivációra hatnak a támogatások, valamint a közösség által generált 
kényszer is. Érdemes megnézni az összefüggéseket, hiszen a külső szabályozás az erőltetett elköteleződéssel is kapcsolatban áll. Ez az összefüggés a biztatások, tanácsok és a közösségi, valamint a társadalom által elvárt teljesítmények miatt látható. Ezek mellet fontos látni, hogy a közösségi támogatás - informális az integrált szabályozásban is szerepet játszik, ezért talán nem csak kényszert okozhatnak a támogatások, hanem biztatások révén a sportolók szívesebben is üzhetik sportágukat.

A törekvés a fejlödésre - képesség és a személyes befektetések - veszteség három, míg az értékes lehetőségek két extrinzik elemen is megjelent. A faktorok komplex jelensége miatt ezeket érdemes külön is megvizsgálni. A törekvés a fejlödésre - képesség elem leírja az egyén törekvését, hogy fejlődjön és eredményt érjen el (Scanlan és mtsai, 2016). A sportolóknak nem csak belső, hanem külső faktorok is befolyásolhatják teljesítményüket. Például, azok a sportolók, akik nagyobb teljesítményre vágynak, tudják, hogy időt kell szakítani az edzésekre, melyeket nem hagyhatnak ki. Ilyenkor a sportoló teljesítményében szerepet játszhat a lelkiismerete (introjekció), mivel tudja, hogy nem szabad kihagyni az edzést, valamint annak a felismerése, hogy milyen fontos az edzés és a képességének fejlesztése (identifikáció). Továbbá ennek a felismerésnek az alapját képezhetik a sportoló céljai (integráció) is melyet elkíván érni a ráfordított edzéssel.

Két fő oka van a személyes befektetések - veszteség megjelenésének a különböző extrinzik elemek között. Először is a változó leírja azokat a külső tényezőket, melyek nagyban hozzájárulhatnak az extrinzik motivációhoz (pénz, energia befektetés). Másodsorban ezek elvesztése kapcsolatban lehet a lelkiismerettel, hiszen talán ezeket a sportolók lelkiismeretük miatt jobban féltik.

$\mathrm{Az}$ értékes lehetőségek, mint a lelkes elkötelezödés forrásai jelenek meg a szakirodalomban. A mintámban azonban pozitív kapcsolata is van az identifikált és az integrált szabályozással. Kvalitatív tanulmányok szerint az értékes lehetőségek tág jelentéssel bírnak a sportági élmény leírásában, hiszen jelenthetik a versenyzést, utazást a mozgásélményt és akár az edzést is (Scanlan és mtsai, 2009). Ezért a lehetőségek az extrinzik motiváció révén a lelkes elköteleződést erősíthetik.

Elemzésem utolsó részében megvizsgáltam az intrinzik motivációra ható elemeket. Ahogy vártam a sportélvezet és a törekvés a fejlödésre - képesség változók fontos forrásai voltak az intrinzik motivációnak. Ugyanakkor az értékes lehetöségek nem mutattak szignifikáns kapcsolatot a felállított hipotézisekhez képest. Mint már az előbb említettem az értékes lehetőségek komplex jelentéssel bírhat, hiszen megnyilvánulhat külső (versenyzés élménye) és belső (mozgásélmény) motivációval is. A külső elemei révén erősíthetik 
továbbá a motivációt és az elköteleződést. A három sport-elköteleződés változó (törekvés a fejlödésre - képesség; személyes befektetése - veszteség; közösségi támogatás - informális) nem csak az intrinzik motivációt, hanem az egész öndeterminációs kontinuumot végig kísérik. Ennek okai abban keresendők, hogy a sport-elköteleződés forrásai nem korlátozódnak le egy adott fogalomra, hanem tág jelentéssel bírnak. Például a törekvés a fejlődésre - képesség jelentheti a belső késztetést, hogy a sportoló fejlődjön, de jelentheti az életcélját is, mely már az extrinzik motivációban mutatkozhat meg, vagy a közösségi támogatás - informális, mely a támogatása révén kényszert és biztatást is tehet a sportolóra.

Összefoglalásképpen elmondhatjuk, hogy az elköteleződés típusai jól elkülöníthetőek egymástól, de az elköteleződés forrásai már egy komplexebb modellt képviselnek, melyek összefüggnek egymással. Például egy sportoló, aki azért sportol, mert mások támogatják, talán kényszert érez emiatt, de hosszú távon eredményezheti azt is, hogy beépül az életébe és megjelenek a céljai, melyek hozzájárulhatnak ahhoz, hogy magasabb elégedettséggel rendelkezzen és így elköteleződjön a sportága iránt.

Sajnos három változó nem került be a vizsgálatba, melyeket fontosnak tartok megemlíteni (törekvés a fejlödésre - közösség; közösségi támogatás - érzelmi, személyes befektetések - mennyiségi). Ezek további vizsgálatokat igényelnek, és nagyobb elemszámmal talán még pontosabb képet kapnánk a sport-elköteleződés forrásairól

Hipotéziseimmel kapcsolatban a következő megállapításokat tehetem: 1) Beigazolódott a sport-elköteleződés típusaira tett hipotézisem $\left(\mathrm{H}_{3}\right)$, hiszen a magasabb öndetermináció a lelkes elkötelezödéssel áll kapcsolatban, míg az alacsony önndeterminációs az erőltetett elkötelezödéssel. 2) Részben igazolódott a sportelköteleződés modell forrásaira tett hipotézisem $\left(\mathrm{H}_{4}\right)$. Nagyon úgy tünik, hogy az elköteleződés forrásai egy sokkal komplexebb fogalommal bírnak, így könnyen megjelenhettek az öndetermináció több szakaszában is.

\subsubsection{A sportolói identitás összefüggései a sport iránti elköteleződéssel}

A fejezetben célom, hogy megvizsgáljam a sport-elköteleződést a sportolói identitás kontextusából. Az elemzés a második vizsgálat adataiból valósult meg ( $\mathrm{n}=356$ ). Eredményeim értékeléshez a szociodemográfiai és sportolási szokások kérdőíveken túl a sport-elköteleződés kérdőív-2, és a sportolói identitás skálákat használtam fel. Az elemzésemben kíváncsi voltam a sport-elköteleződés modell és a sportolói identitás kapcsolatára és megnézem, hogy az identitás, hogyan tér el nemenként, koronként és sportáganként is. 


\subsubsection{Statisztikai módszer}

Az adatok feldolgozása SPSS statisztikai szoftverrel történt. Az elemzés során a leíró statisztikán túl a szociodemográfiai és a sportváltozók szerinti összehasonlítást kétmintás tpróbával, egyszempontos varianciaanalízissel végeztem, a változók erősségének mérésére Pearson korrelációt használtam. A sportolói identitás és a sport iránti elköteleződés kapcsolatát többváltozós „stepwise” regressziós elemzéssel tártam fel.

\subsubsection{Eredmények}

Az adatok elemzését a szociodemográfiai és a sporttal kapcsolat változók vizsgálatával kezdem. Először kétmintás t-próbával megvizsgáltam, hogyan tér el a sportolói identitás nemenként, tagozatonként és az egyéni, valamint csapatsportolók között. Ezután egyszempontos varianciaanalízissel megvizsgáltam a különbségeket sportolási szintenként és sportágtípusonként. Az eredményeket az 15. táblázat foglalja össze. Valamennyi vizsgált változó szignifikáns különbséget mutatott.

15. táblázat. Sportoló identitás különbségei szociodemográfiai és sport változók mentén

\begin{tabular}{|c|c|c|c|}
\hline Kétmintás t-próba & & $\begin{array}{c}\text { Sportolói } \\
\text { Identitás } \\
\text { (átlag, szóra) }\end{array}$ & t-érték \\
\hline \multirow{2}{*}{ Nem } & Fiú & $54,59(10,96)$ & \multirow{2}{*}{$6,93 * * *$} \\
\hline & Leány & $42,80(17,05)$ & \\
\hline \multirow{2}{*}{ Iskolai tagozat } & Sporttagozat & $49,60(15,04)$ & \multirow{2}{*}{$5,71 * * *$} \\
\hline & Nem sporttagozat & $36,13(16,38)$ & \\
\hline \multirow{2}{*}{ Egyéni / Csapat sportolók } & Egyéni sportolók & $42,06(16,86)$ & \multirow{2}{*}{$-6,56 * * *$} \\
\hline & Csapat sportolók & $53,00(13,03)$ & \\
\hline \multirow{2}{*}{$\begin{array}{l}\text { Egyszempontos } \\
\text { varianciaanalízis }\end{array}$} & & Sportolói & \multirow[b]{2}{*}{ f-érték } \\
\hline & & $\begin{array}{c}\text { Identitás } \\
\text { (átlag, szóra) }\end{array}$ & \\
\hline \multirow{4}{*}{ Versenyzés szintje } & Nemzetközi szint & $57,71(8,70)$ & \multirow{4}{*}{$117,37 * * *$} \\
\hline & Országos szint & $54,82(9,94)$ & \\
\hline & Helyi, megyei szint & $40,70(14,88)$ & \\
\hline & Hobbi szint & $26,79(11,71)$ & \\
\hline \multirow{4}{*}{ Sportágtípus } & Taktikai sportágak & $52,68(13,24)$ & \multirow{4}{*}{$21,84 * * *$} \\
\hline & Állóképességi sportágak & $44,82(17,36)$ & \\
\hline & Müvészeti sportágak & $35,03(14,66)$ & \\
\hline & Küzdősportok & $44,00(17,40)$ & \\
\hline
\end{tabular}

Megjegyzés: ***p<0,001

A fiúk nagyobb fokú sportolói identitással rendelkeznek, mint a leányok ( $\mathrm{p}<0,01)$, és a sporttagozatos diákok is jelentősen magasabb pontszámot értek el, mint a nem 
sporttagozatos társaik ( $<$ 0,01). Egyéni és a csapat sportolókat vizsgálva azt tapasztaltuk, hogy a csapatsportágak képviselőinek magasabb az identitásindexe ( $\mathrm{p}<0,01)$, mint az egyéni sportágakat űzőké. Összehasonlítva a különböző sportolási szintek képviselőit, azt tapasztalhatjuk, hogy minél magasabb szinten sportol valaki, annál magasabb lesz a sportolói önazonossága. Mintánkban a nemzetközi szinten versenyzők, azaz a válogatott sportolók érték el a legmagasabb pontszámot $(\mathrm{p}<0,01)$, mely folyamatosan csökken a sportolási szint csökkenésével. A sportágtípusoknál is jelentős eltérések találhatóak. A legmagasabb identitási indexet a taktikai sportágak képviselői érték el ( $\mathrm{p}<0,01)$, ami nem meglepő, hiszen ök zömmel valamilyen csapatjátékot üznek. Az állóképességi és a küzdősportágakban sportolók hasonló értéket értek el, ám a müvészeti sportágak képviselői átlag alatti identitással rendelkeznek a mintánkban.

Vizsgálatom második részében megnéztem, hogy a kor, a sportban és versenyzésben eltöltött évek és az edzésmennyiség milyen kapcsolatban állnak a sportolói identitással (16. táblázat). A serdülök sportolási szokására jellemző, hogy a kor előrehaladtával csökken a sportolási kedv. Ez a mi eredményünkből is meglátszik, hiszen a sportolói identitás index (r $=-0,36)$, valamint a heti edzésmennyiség $(\mathrm{r}=-0,20)$ a korral negatívan változik. Ugyanakkor a mintában szereplö serdülöknél pozitív kapcsolat mutatható ki a sportban eltöltött évek számával $(\mathrm{r}=0,31)$ a versenyzésben eltöltött évek számával $(\mathrm{r}=0,52)$ és a heti edzésmennyiséggel $(\mathrm{r}=0,54)$. Így kijelenthetjük, hogy minél régebb óta sportol és versenyez valaki, annál többet fog edzeni, ami erőteljesebb sportolói identitáshoz vezethet.

16. táblázat. Korrelációs kapcsolatok a sportolói identitás az életkor és sport változók között

\begin{tabular}{llllll}
\hline & \multicolumn{1}{c}{1} & 2 & 3 & 4 & 5 \\
\hline 1. Sportolói Identitás Index & 1 & & & & \\
2. Kor & $-0,36^{* *}$ & 1 & & & \\
3. Hány éve sportolsz? & $0,31^{* *}$ & 0,10 & 1 & & \\
4. Hány éve sportolsz versenyszerüen? & $0,52^{* *}$ & 0,02 & $0,61^{* *}$ & 1 & \\
5. Heti hány órát töltesz edzéssel? & $0,54^{* *}$ & $-0,20^{* *}$ & $0,22^{* *}$ &, $40^{* *}$ & 1 \\
\hline
\end{tabular}
Megjegyzés: $* * p<0,01$

Vizsgálatom 3. részében arra voltam kíváncsi, hogy a sport iránti elköteleződés milyen változókon keresztül hat a sportolói identitásra (17. táblázat). Ennek felderítésére ún. többváltozós lineáris regressziót alkalmaztam „stepwise” módszerrel. A kapott eredmények a végső modellt a variancia 78 százalékában magyarázták. Összesen kilenc változó került a modellbe. A személyes befektetések - mennyiség $(\beta=0,25)$ és a lelkes elköteleződés $(\beta=$ 
0,44) rendelkeznek a legnagyobb magyarázó erővel a sportolói identitásra. Az értékes lehetöségek $(\beta=0,15)$, a törekvés a fejlödésre - közösség $(\beta=0,18)$, az erőltetett elköteleződés $(\beta=0,07)$ és a közösségi támogatás - érzelmi $(\beta=0,08)$ változók szignifikánsan pozitív magyarázó erővel bírnak a modellben. Érdekes módon a sportélvezet $(\beta=-0,10)$ és a törekvés a fejlödésre - képesség $(\beta=-0,11)$ szignifikánsan negatív magyarázó erőt mutatnak. A közösségi kényszer $(\beta=0,06)$ ugyan bekerült a modellbe, de a végső változatban elveszítette a szignifikáns hatását. A személyes befektetések - veszteség, egyéb prioritások és a közösségi támogatás - informális változók a regressziós módszer sajátosságai miatt kizárásra kerültek. 
17. táblázat. Sportolói identitást és sport iránti elkötelezödés regressziós kapcsolata

\begin{tabular}{|c|c|c|c|c|c|c|}
\hline & & $\mathrm{F}$ & $\mathrm{R}_{2}$ & $\beta$ & SE $\beta$ & $\mathrm{t}$ \\
\hline \multirow[t]{2}{*}{ Step 1} & & 533,70 & 0,62 & & & \\
\hline & Személyes befektetések - mennyiségi & & & 13,80 & 0,78 & $23,10 * * *$ \\
\hline \multirow[t]{3}{*}{ Step 2} & & 384,80 & 0,70 & & & \\
\hline & Személyes befektetések - mennyiségi & & & 8,37 & 0,47 & $10,75_{* * *}$ \\
\hline & Lelkes elköteleződés & & & 6,67 & 0,42 & $9,28 * * *$ \\
\hline \multirow[t]{4}{*}{ Step 3} & & 296,60 & 0,73 & & & \\
\hline & Személyes befektetések - mennyiségi & & & 6,06 & 0,35 & $7,28_{* * *}$ \\
\hline & Lelkes elköteleződés & & & 4,98 & 0,32 & $6,88_{* * *}$ \\
\hline & Értékes lehetőségek & & & 3,91 & 0,28 & $6,05 * * *$ \\
\hline \multirow[t]{5}{*}{ Step 4} & & 242,52 & 0,74 & & & \\
\hline & Személyes befektetések - mennyiségi & & & 4,70 & 0,27 & $5,48^{* * * *}$ \\
\hline & Lelkes elköteleződés & & & 5,19 & 0,33 & $7,38 * * *$ \\
\hline & Értékes lehetőségek & & & 3,27 & 0,24 & $5,11_{* * *}$ \\
\hline & Közösségi kényszer & & & 2,29 & 0,17 & $4,72 * * *$ \\
\hline \multirow[t]{6}{*}{ Step 5} & & 204,80 & 0,75 & & & \\
\hline & Személyes befektetések - mennyiségi & & & 4,94 & 0,28 & $5,86 * * *$ \\
\hline & Lelkes elköteleződés & & & 6,28 & 0,40 & $8,41_{* * *}$ \\
\hline & Értékes lehetőségek & & & 3,19 & 0,23 & $5,08_{* * *}^{*}$ \\
\hline & Közösségi kényszer & & & 1,96 & 0,15 & $4,06 * * *$ \\
\hline & Sportélvezet & & & $-3,36$ & $-0,12$ & $-3,78 * * *$ \\
\hline \multirow[t]{7}{*}{ Step 6} & & 180,53 & 0,76 & & & \\
\hline & Személyes befektetések - mennyiségi & & & 4,05 & 0,23 & $4,73_{* * *}^{*}$ \\
\hline & Lelkes elköteleződés & & & 5,91 & 0,37 & $8,01 * * *$ \\
\hline & Értékes lehetőségek & & & 2,63 & 0,19 & $4,16 * * *$ \\
\hline & Közösségi kényszer & & & 1,74 & 0,13 & $3,65 * * *$ \\
\hline & Sportélvezet & & & $-3,63$ & $-0,13$ & $-4,16 * * *$ \\
\hline & Törekvés a teljesítésre - közösség & & & 2,62 & 0,16 & $3,87_{* * *}$ \\
\hline \multirow{8}{*}{ Step 7} & & 157,82 & 0,76 & & & \\
\hline & Személyes befektetések - mennyiségi & & & 4,10 & 0,23 & $4,82_{* * *}$ \\
\hline & Lelkes elköteleződés & & & 6,32 & 0,40 & $8,40 * * *$ \\
\hline & Értékes lehetőségek & & & 2,46 & 0,18 & $3,89_{* * *}$ \\
\hline & Közösségi kényszer & & & 1,31 & 0,10 & $2,60 * * *$ \\
\hline & Sportélvezet & & & $-3,12$ & $-0,11$ & $-3,50 * * *$ \\
\hline & Törekvés a teljesítésre - közösség & & & 2,65 & 0,16 & $3,94_{* * *}$ \\
\hline & Eröltetett elkötelezödés & & & 1,34 & 0,08 & $2,39 * * *$ \\
\hline \multirow[t]{9}{*}{ Step 8} & & 140,22 & 0,77 & & & \\
\hline & Személyes befektetések - mennyiségi & & & 3,77 & 0,22 & $4,40 * * *$ \\
\hline & Lelkes elköteleződés & & & 6,33 & 0,40 & $8,46 * * *$ \\
\hline & Értékes lehetőségek & & & 2,27 & 0,16 & $3,58_{* * *}$ \\
\hline & Közösségi kényszer & & & 1,10 & 0,08 & $2,15 *$ \\
\hline & Sportélvezet & & & $-3,00$ & $-0,11$ & $-3,38 * *$ \\
\hline & Törekvés a teljesítésre - közösség & & & 2,52 & 0,15 & $3,76 * * *$ \\
\hline & Eröltetett elköteleződés & & & 1,54 & 0,09 & $2,73 *$ \\
\hline & Közösségi támogatás - érzelmi & & & 1,05 & 0,07 & $2,15 * *$ \\
\hline \multirow[t]{10}{*}{ Step 9} & & 129,07 & 0,78 & & & \\
\hline & Személyes befektetések - mennyiségi & & & 4,38 & 0,25 & $4,92 * * *$ \\
\hline & Lelkes elköteleződés & & & 7,04 & 0,44 & $8,78 * * *$ \\
\hline & Értékes lehetőségek & & & 2,20 & 0,15 & $3,49_{* *}$ \\
\hline & Közösségi kényszer & & & 0,86 & 0,06 & 1,67 \\
\hline & Sportélvezet & & & $-2,71$ & $-0,10$ & $-3,11_{* * *}$ \\
\hline & Törekvés a teljesítésre - közösség & & & 2,99 & 0,18 & $4,31 * * *$ \\
\hline & Erőltetett elköteleződés & & & 1,36 & 0,07 & $2,39_{* * *}$ \\
\hline & Közösségi támogatás - érzelmi & & & 1,27 & 0,08 & $2,59 *$ \\
\hline & Törekvés a teljesítésre - képesség & & & $-2,27$ & $-0,11$ & $-2,37 *$ \\
\hline
\end{tabular}

Megjegyzés: ${ }^{*} \mathrm{p}<0,05 ;{ }^{*} \mathrm{p}<0,01 ; * * * \mathrm{p}<0,001$ 


\subsubsection{Megbeszélés}

A vizsgálat fókuszában a serdülő sportolók ún. sportolói identitásának a vizsgálata állt. Ezt a kérdést egyfelől a szociodemográfiai és sportolási szokásokkal kapcsolatos változók felől közelítettem meg, másfelől megvizsgáltam a sportolói identitás és a sport iránti elköteleződés kapcsolatát. A szociodemográfiai és sportolási szokásokkal kapcsolatos elemzések a nemzetközi szakirodalommal megegyező eredményeket hoztak, azonban a két modell összehasonlításának nemzetközi kontextusba helyezésére nem volt mód, mivel eddig nem készült átfogó előzetes tanulmány.

A szociodemográfiai adatok és a sportolási szokások elemzése a szakirodalommal megegyező eredményeket hozott. A szakirodalom szerint a fiúk többet sportolnak és motiváltabbak, mint a lányok (Keresztes, Pluhár és Pikó, 2003), valamint a kor elörehaladtával csökken a sportolási kedv (Kimm és mtsai, 2000). Úgy tünik nincs ez másképp a sportolói identitás terén sem, hiszen a fiúknál jelentősen magasabb értéket találtunk, mint a lányoknál, és a kor is negatívan korrelált a sportolói identitás indexszel.

A sport iránti elköteleződésről szóló eredményeim azt mutatták, hogy aki magasabb szinten köteleződik el a sportága iránt, régebb óta sportol, többet időt fektet sportágába, és magasabb szinten is úzi azt, mint a kevésbé elkötelezettek. Ez azzal magyarázható, hogy az elköteleződés nemcsak sportág szeretetéből fakadhat, hanem az eredmények és a befektetett energia is hatással lehet a sportolóra. Ez a megfigyelés igaz ezen kutatás eredményeire is. A sportolási szinttel nőtt az identitás-index mértéke is, és korrelációs elemzésem is ezt a tézist igazolta, hiszen a sportban és a versenyzésben eltöltött évek, valamint az edzésmennyiség is pozitívan korrelálnak a sportolói identitás indexszel. Azaz minél régebb óta sportol valaki, annál többet fektet bele, így magasabb fokú lesz az identitása is.

A sporttagozatos diákok magasabb sportolói identitással rendelkeznek, ám ez nem meglepő, hiszen közülük kerültek ki azok a sportolók, akik magasabb szinten versenyeznek, és többet eddzenek, mint a nem sporttagozatos serdülők. A sportági típusok összehasonlítását a szakirodalom óvatosan kezeli, hiszen a vizsgálatok igen széles skálán mozgó eredményekről számolnak be (pl.: Mikulán és Pikó, 2012; Jakobsen, 2014). Tanulmányunkban a csapatsportágak képviselői rendelkeznek a legnagyobb mértékü identitással (mindkét csoportosítás szerint). Ennek okát abban látjuk, hogy a csapatsportágakban a közösségnek és a csapatkohéziónak köszönhetően jobban tudnak a sportolók kötődni saját sportágukhoz és csapattársaikhoz, így kialakítva az erősebb identitást. Az önazonosságot az is növelheti, hogy a csapatsportágat üző sportolók egymást biztatva egymásért is sportolnak, növelve a sportág iránti szeretetet (Mikulán és Pikó, 2012). 
Fontos megjegyezni, hogy a korábbi identitást és az öndeterminációt vizsgáló tanulmányok erős korrelációt találtak a sportolói identitás és az identifikáció, valamint integráció között. Az identifikált és az integrált szabályozási formák alapvetően az extrinzik motivációhoz tartoznak, ugyanakkor tartalmazhatnak intrinzik elemeket is (Deci és Ryan, 2000). Ezek az elemek valamilyen belső indíttatásra (pl.: lelkiismeret) vagy célokra utalhatnak, melyek kapcsolatban állhatnak a sportolói identitással is. Fontos megjegyezni továbbá, hogy a csapatsportágak legfőképpen az extrinzik elemekből táplálkoznak (Jakobsen, 2014). Úgy látom ezek az eredmények összehangban vannak az előző fejezetekben tárgyalt sportelköteleződés modell összefüggéseivel is.

A vizsgálat második részében arra voltam kíváncsi, hogy milyen kapcsolat található a sportolói identitás és a sport iránti elköteleződés között. A „stepwise” többváltozós regresszió elemzés számos meglepő eredményt hozott. A sportolói identitást a személyes befektetések - mennyiség és a lelkes elköteleződés magyarázzák a legnagyobb mértékben. Ezt az eredményt legjobban maga a sportolói identitás fogalma magyarázza. Hiszen ez a fogalom a sportolói szerep köré épül, amelyet a sport iránti vágy (lelkes elköteleződés), valamint annak mértéke adja, amit a személyes befektetések - mennyiség képvisel (Brewer és mtsai, 1993). Azaz a magas fokú sportolói identitás kialakulásához fontos a sport iránti vágy, és hogy a sportoló minél többet fektessen a sportágába.

Az értékes lehetőségek, törekvés a fejlödés - közösség, közösségi támogatás - érzelmi és az erőltetett elköteleződés is közel azonos pozitív magyarázó erővel rendelkezetek. Úgy gondolom, hogy a lehetőségek fontos részét képezhetik a sportolók identitásának, hiszen a sportolók ragaszkodása egy-egy versenyhez, helyszínhez vagy tevékenységhez növelheti önazonosságukat. A közösségi szintü változók arányát talán az identitás jellege adja, hiszen a mintában a csapatsportágak szerepének is nagy a jelentősége. Ez a sportolói közösség identitásformáló erejét igazolja. Ebben az eredményben is közrejátszhatott, hogy a már említett öndeterminációs elmélet is kiemeli az extrinzik elemekkel való kapcsolatot (Strachan és mtsai, 2013; Vlachopoulos, Kaperoni és Moustaka, 2011).

Igen meglepett, hogy az erőltetett elkötelezödés pozitív magyarázó erőként jelenik meg a végső modellben. Korábbi kutatások inkább a sportot, gátló és az arra ható kötelezettségeként írták le ezt a faktort (Scanlan és mtsai, 2016). Ám ez az eredmény arra enged következtetni, hogy a sportolói identitást nemcsak a belső indíttatás táplálja, hanem a külső motiváció és a kényszer is megjelenhet a sportolók identitásában, vagyis azok a sportolók, akik magas fokú identitással rendelkeznek, nem feltétlenül a sport szeretete és annak vágya miatt sportolnak. Előfordul, hogy kényszer és kötelességtudat alakítja az 
identitást, hiszen magasabb sportolási szinteken ezek is késztetést jelenthetnek a további versenyzéshez (Chantal és mtsai, 1996; Scanlan és mtsai, 2009).

További nem várt eredmény, hogy a sportélvezet és a törekvés a fejlödére - képesség, negatív magyarázó erővel rendelkeznek. Ez igen meglepett, hiszen mind a két elem a szakirodalomban, mint a sportmotiváció és elköteleződés pozitív erősítő elemeként szerepel (Scanlan és mtsai, 1993, 2016). Jelen kutatásban azonban úgy tünik, hogy az örömnek és az egyéni fejlődésnek a sportban nincs akkora jelentősége a sportolói identitás formálódásában. Utóbbi elem negatív eredménye talán azzal magyarázható, hogy a törekvés a fejlődésre közösségi változóval ellentétet alkothatnak, de sajnos erre nagyon kevés információval szolgál a szakirodalom. A sportélvezet és a törekvés a fejlödésre - képesség ilyen jellegü eredménye azt mutathatja, hogy a sportolás örömének és az egyéni fejlődésnek a mértéke önmagában cél, és nincs nagy jelentősége a sportolók identitásra.

Összefoglalásként elmondható, hogy a sportolói identitásra hatással vannak a szociodemográfiai adatok és a sportolási szokások. A különböző sportmotivációs tanulmányokkal (pl.: Strachan és mtsai, 2013; Vlachopoulos és mtsai, 2011) megegyezően, a sportolói identitás szintje különbözik a nemenként, tagozatoként, sportolási szintekként és függ a kortól, a sportágban eltöltött időtől és az edzésmennyiségtől is. Csak úgy, mint a sport-elköteleződés modell vizsgálatánál, itt is arra a megállapításra jutottam, hogy a magasabb identitás a csapatsportolókra jellemző. A sportolói identitás és a sport iránti elköteleződés közötti összefüggések eredményei csupán részben igazolták hipotézisemet (H5), hiszen a sportélvezet és törekvés a fejlödésre - képesség faktorok (mely nagymértékben kapcsolódnak a belső motivációhoz) negatív kapcsolatban állnak az identitással, ugyanakkor előzetes feltételezésemmel megegyezően a lelkes elköteleződés, az értékes lehetőségek és a személyes befektetések - mennyiség mind pozitív kapcsolatban állnak a sportolói identitással. Az identitás kapcsolata az eröltetett elkötelezödéssel is nem várt eredményt mutatott ( $\left.\mathrm{H}_{6}\right)$, hiszen annak pozitív magyarázó ereje arra enged következtetni, hogy a kényszerből sportolóknál is magas lehet a sportolói identitás. 


\subsection{Az egészségpszichológia szerpe a sport-elköteleződés modellben}

Az eredményeim következő tematikus egységében célom bemutatni mintám összefüggéseit a sport-elköteleződés modellel, mely magába foglalja a modellen belüli és kívüli összefüggéseket, így megvizsgálom, hogy az elköteleződés típusok és források, hogyan viszonyulnak egymáshoz, valamint megvizsgálom azokat az egészség-pszichológiai változókat, amelyeket befolyásolhat a sport-elköteleződés. Az alfejezetek a negyedik kérdéskör és a hozzá kapcsolódó hipotézisek (H7- H10) megvitatását tartalmazzák.

\subsubsection{A sport-elköteleződés modell összefüggései}

Az előzőekben a sport-elköteleződés kapcsolatát vizsgáltam meg a szociodemográfiai változókkal, sportolási szokásokkal és más motivációs megközelítésekkel. Ebben a fejezetben azt vizsgálom, hogy a sport-elköteleződés modell, forrásai és típusai között, milyen kapcsolat található a mintámon, valamint célom, hogy a modellbe bevonjam a pszichológiai és egészségattitüd változókat is. Az elemzésem az első vizsgálat adataiból (n = 526) valósult meg, a sport-elköteleződés-2, jövőorientáció és az egészségattitűd skálák elemzésével.

\subsubsection{Statisztikai módszer}

$\mathrm{Az}$ adatok vizsgálatát útelemzéssel végeztem el, melyhez az AMOS 22.0 szoftvert használtam. A felépített modell illeszkedési mutatóit a következő értékekkel mértem: khi négyzet ( $\chi 2)$, a khi négyzet valamint a szabadságfok hányadosából adódó érték (CMIN/d.f); root mean square error of approximation (RMSEA); a Tucker-Lewis index (TLI); comparative fit index (CFI); standardized root mean square residual (SRMR). A fittségi mutatók elfogadható értékeit a 5.1.1.1.-es fejezetben korában már részleteztem.

\subsubsection{Eredmények}

A szakirodalommal, összhangban egy elméleti modellt állítottam fel, ahol feltételeztem, hogy az elköteleződés valamennyi forrása kapcsolatban állhat a kétféle elköteleződés típussal (Scanlan és mtsai, 2016). Ezenkívül kipróbálásra került két új változó, így hozzáadtam a modellhez a jövőorientáció és egészségattitüdök pszichológiai változókat is. Célom volt, kimutatni, hogy a sport iránti elköteleződés hatással lehet az egészségpszichológiára.

A modell kapcsolatait a 14. ábra foglalja össze, mely megfelelőn illeszkedett az adataimra $\left(\mathrm{X}_{2}(23)=61,88 ; \mathrm{CMIN} /\right.$ d.f. $=2,69 ; \mathrm{CFI}=0,98 ; \mathrm{RMSEA}=0,06 ; \mathrm{SRMR}=0,03$; 
TLI=0,93). A lelkes elköteleződést a források a variancia 72 százalékában magyarázták. Ahogy az ábrán látható a lelkes elkötelezödésnek szignifikánsan pozitív kapcsolat volt sportélvezet $(\beta=0,31)$, értékes lehetöségek $(\beta=0,48)$, törekvés a fejlödésre - képesség $(\beta=$ $0,28)$ és személyes befektetések - mennyiség $(\beta=0,23)$ változókkal. Míg az egyéb prioritások ( $\beta=-0,10)$, közösségi támogatás - informális $(\beta=-0,06)$ negatív kapcsolatot mutattak a lelkes elkötelezödéssel. Az erőltetett elkötelezödést a források a variancia 43 százalékban magyarázták. Az egyéb prioritások $(\beta=0,22)$, személyes befektetés - veszteség $(\beta=0,25)$, közösségi támogatás - informális $(\beta=0,13)$ és a közösségi kényszer $(\beta=0,27)$ pozitívan míg a sportélvezet $(\beta=-0,28)$, törekvés a fejlödésre - képesség $(\beta=-0,16)$ és a közösség támogatás - érzelmi $(\beta=-0,16)$ negatívan kapcsolódtak az erőltetett elkötelezödéshez.

A modellhez két új változót is hozzáadtam. Az eredményeim azt mutatták, hogy a jövőorientáltság $\left(\mathrm{R}_{2}=0,08\right)$ pozitív kapcsolatban van a lelkes $(\beta=0,24)$ és negatív kapcsolatban az eröltetett elkötelezödéssel ( $\beta=-0,13)$. Úgy néz ki, hogy az egészségattitüdöknek $\left(\mathrm{R}_{2}=0,04\right)$ is szerepe van a modellben. Igaz a lelkes elkötelezödéssel nem mutatható ki kapcsolat, de az eröltetett elkötelezödéssel $(\beta=0,12)$ pozitív kapcsolatban áll. Ezért úgy látom ez talán egy új forrása lehet az erőltetett elköteleződésnek. 


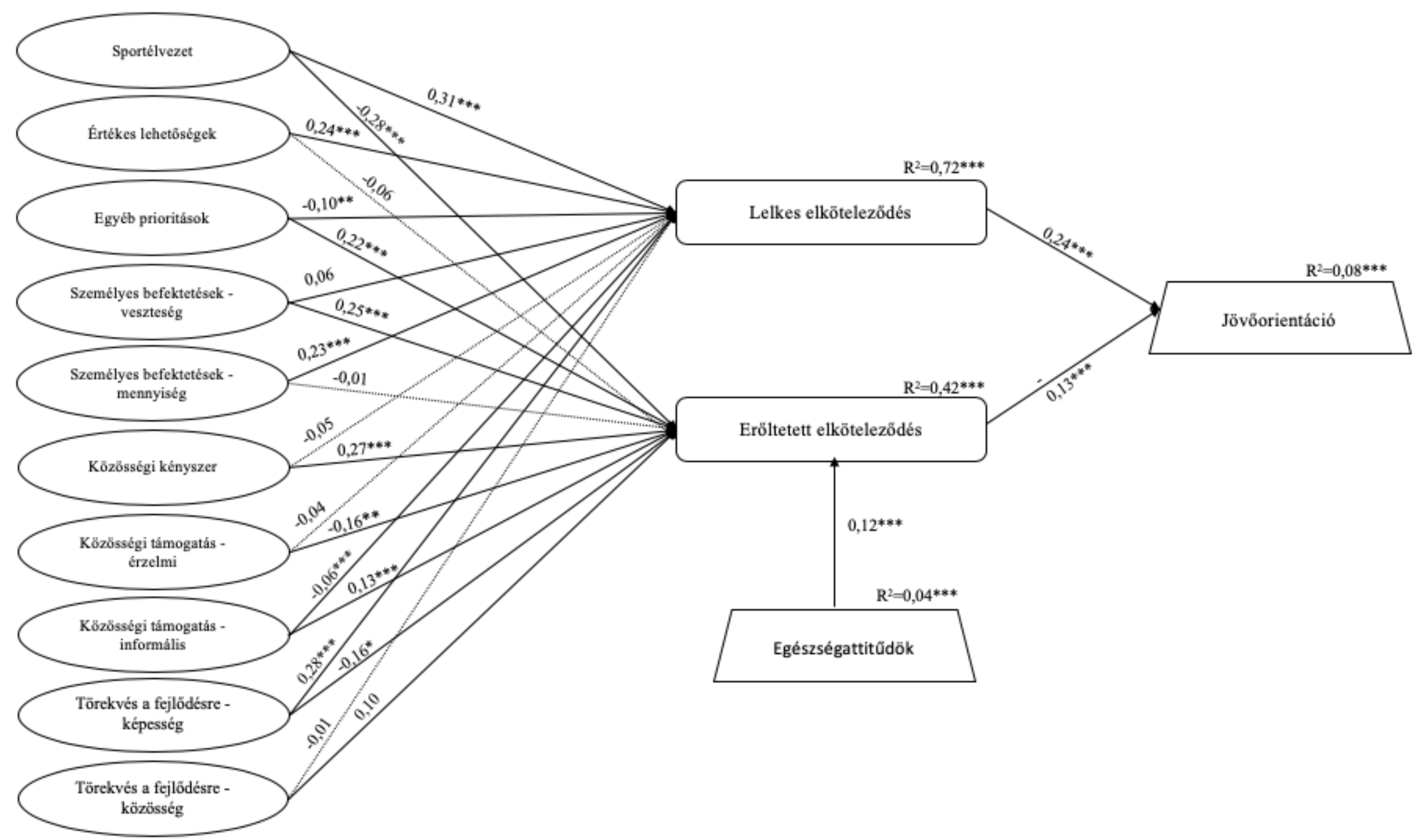

14. ábra. A sport elkötelezödés modell kapcsolatai és kapcsolata az egészségattitüdökkel és jövőorientációval 


\subsubsection{Megbeszélés}

A fejezet célja volt bemutatni, hogy sport-elköteleződés források, milyen kapcsolatban állnak a kétféle elköteleződés típussal. Valamint azt is megnéztem, hogy a sportelköteleződés modell milyen kapcsolatban állhat egészségpszichológiai tényezőkkel.

A vizsgálatom, számos érdekes eredményt megmutatott a magyar minta sport iránti elköteleződésének összefüggéséről, mely hipotéziseimmel és a szakirodalommal összhangban álltak. A sportélvezet, értékes lehetöségek és egyéb prioritások hármasa nem meglepő eredményt hozott, hiszen a nemzetközi szakirodalom is hasonlóan ír ezekről a forrásokról (Scanlan és mtsai, 2016; Weiss és Weiss, 2003; Wilson és mtsai, 2004). Így hipotézisemmel összhangban megállapíthatom $(\mathrm{H} 7)$, hogy a sportélvezet, értékes lehetőségek erősítik a lelkes és gyengítik az erőltetett elkötelezödést (értékes lehetőségek nem szignifikánsan, de negatív kapcsolatban áll), míg az egyéb prioritások erősíti az erőltetett és gyengíti a lelkes elköteleződést.

A két befektetés változó eredményei is részben igazolták az előzetes várakozásaimat. Úgy tünik, hogy a minta sportolói, lelkes elkötelezödéséhez, hozzátartozik, hogy sokat fektetnek a sportágukba, míg az erőltetett elkötelezödés a befektetések elvesztésével áll kapcsoltban, hiszen az addig befektet idő, pénz, energiának az elvesztése miatt, kényszert érezhet a sportoló, hogy folytassa sportágát.

Sajnos a közösségi változók eredményeit már nem ilyen könnyü megítélni. Az eredményeimben és a szakirodalomban is következetlen eredményeket találhatunk (Carpenter és mtsai, 1993; Scanlan és mtsai, 1993, 2016). Azonban várható eredmény volt a közösségi kényszer pozitív kapcsolata az erőltetett elköteleződéssel, ám a kétféle közösségi támogatás eredményei igen megleptek. Például a közösségi támogatás - informális a lelkes elköteleződésnél negatívan míg az erőltetett elkötelezödésnél pozitívan jelenik meg. A szakirodalomban találunk példát arra, hogy a támogatások inkább erősítik a sportág iránti vágyat (Weisz és Wood, 2005). Az eredményeim oka talán az edzőktől, érkező elvárásokból eredeztethetőek. Számos kutatás megmutatta már, hogy az edzőktől érkező elvárások szorongással is járhatnak, mivel a sportoló fél, hogy azokat nem tudja teljesíteni (Atkin és mtsai, 2015). Az érzelmi típusú közösségi támogatások változó negatív kapcsolata az erőltetett elköteleződéssel igen érdekes eredmény. Előzetesen ugyan vártam a kapcsolatát az erőltetett elköteleződéssel, ám annak iránya meglepett. A szülőktől és barátoktól érkező támogatások eredményezhetnek kényszert, de esetünkben negatív elöjele van, mely a lelkes elköteleződésnél is érvényes (igaz ott nem szignifikáns), ezért úgy tűnhet, hogy a 
mintánkban a változónak kevésbé van jelenetősége, de mindenképp további vizsgálatokat igényel az elem.

A törekvés a fejlödésre - képesség ellentétes eredménye sem meglepő, hiszen lelkes elköteleződéshez az egyéni célok fontos forrást jelenthetnek, míg cél nélkül egy adott sport kényszeredetté válhat. Ez mutatkozik meg eredményeinkben is. Az elemről igen kevés vizsgálat áll a rendelkezésünkre, ám egyre inkább úgy tünik, hogy egy fontos elemröl van szó a sport-elköteleződés modellben. Sajnos törekvés a fejlődésre - nem mutatott ki semmilyen szignifikáns kapcsolatot.

A sport-elköteleződés modell összefüggéseit vizsgálva megállapítható a mintámon, hogy a sportolók szeretik sportágukat, melyben lehetőségeket látnak, hiszen fontos nekik a sportág által nyújtott élmény is és elsősorban saját magukért sportolnak, hogy elérjék céljaikat. Ennek hatására hajlandók is sokat belefektetni a szeretett sportjukba. Erre a megállapításra jutott több kutató is, amikor a sport-elköteleződés összefüggéseit vizsgálta, melyek úgy tünik különböző nyelvi és kulturális környezetben is érvényesek (Gabriele és mtsai, 2011; Scanlan és mtsai, 2016; Sousa és mtsai, 2007).

A vizsgálatom második részében új változókat adtam a sport-elköteleződés modellhez, így megvizsgáltam kapcsolatot a jövőorentációval és az egészségattitüdökkel. Korábbi tanulmányok megmutatták, hogy a serdülők hajlamosak elkezdeni sportolni, ha fogyni vagy izomtömeget növelni szeretnének (Frederick és Ryan; 1993; Masten és mtsai, 2010). Ezért az egészségattitüdök szerepe kiemelt lehet, melyet más motivációs tanulmányok sikeresen megerősítettek (Caglar, Canlan, és Demir, 2009; Molanorozi és mtsai, 2014), ám a sport-elköteleződés szempontjából még nem készült kutatás. A kapott eredményeim hipotézisemmel ellentétes $\left(\mathrm{H}_{9}\right)$ irányt mutattak, ugyanis az egészségattitüdök az erőltetett elkötelezödéssel állnak pozitív kapcsolatban. Ennek a számomra meglepő eredménynek az lehet az oka, hogy a sportolók, akik csak az egészségüket miatt kezdenek sportolni, kevésbé szerethetik a sportágukat és esetleg jobban ki lehetnek téve a lemorzsolódás kockázatának. Maga az egészséges szemlélet azonban egy pozitív dolog és nem kizárható, hogy hosszú távon ez az extrinzik jellegủ motiváció intrinzik jellegűvé alakul.

A jövőorientáció eredményei feltételezésemmel összhangban voltak (H9). Korábbi kutatások megállapították, hogy serdülő sportolóknál a szubjektív jóllét (Lyubomirsky, King, és Diener, 2005) és ezáltal a jövőorientáció is magasabb, mint a nem sportoló serdülöknél (Lee és mtsai, 2010). Ez a fajta különbség talán nem csak a sportoló és nem sportoló összehasonlításban áll fenn, hiszen mint eredményeimből feltételezhetjük, akik 
magasabb elköteleződéssel (azaz lelkesen elkötelezettek) magasabb értéket értek el a jövőorientáció terén is mint az alacsonyabban elkötelezettek (azaz erőltetett elkötelezettek). A két eredményből messzemenő következtetést nehéz levonni, hiszen a magyarázó érték is alacsony volt, de mindenképp érdemes tovább vizsgálni a pszichológiai skálák összefüggéseit a sport-elköteleződés modell terén.

Összefoglalásképpen elmondhatom, hogy a vizsgálat a következő megállapításokat hozta a hipotéziseimmel összhangban: 1) Feltételezésem $\left(\mathrm{H}_{7}\right)$ miszerint a sportélvezet, értékes lehetöségek, törekvés a fejlödésre - képesség és személyes befektetések - mennyiség pozitív, míg az egyéb prioritások, közösségi kényszer, negatív kapcsolata van a lelkes elköteleződéssel, igaznak bizonyult. 2) Feltételezésem (H8) miszerint az egyéb prioritások, személyes befektetések - veszteség és a közösségi kényszer pozitív, míg a sportélvezet, értékes lehetőségek negatív kapcsolatban van az eröltetett elköteleződéssel szintén beigazolódott. 3) Feltételezésem (H9) miszerint a magasabb egészségattitüdök és a jövöorientáció értékei a lelkes elköteleződéssel állnak kapcsolatban, csupán részben igazolódott. A jövőorientáció vizsgálata hozta az elözetes feltételezéseimet, de az egészségattitüdök az eröltetett elkötelezödéssel voltak kapcsolatban, ami arra enged következtetni, hogy az egészségért való sportolás a kényszert erősíti a sportolóban.

\subsubsection{A sport-elköteleződés modell kapcsolata az egészségpszichológiával}

A fejezetben megvizsgálom a sport-elköteleződés modell kapcsolatát különböző egészségpszichológiai változókkal. A vizsgálatomban szerepet kap a szubjektív jóllét, jövőorientáció, aspirációk és az egészségattitüdök. Ezeket a változókat igyekeztem más kontextusba helyezni, mint az előző fejezetben, így a modellt felhasználva sportelköteleződés profilok útján elemezem az egészségpszichológiai különbségeket. A profilokat klaszterelemzés használatával Weiss és Weiss (2003) ajánlásai alapján állítottam fel a sport-elköteleződés forrásai segítségével. A vizsgálatomat az első adatgyüjtésből származó adatok $(\mathrm{n}=526)$ alapján végeztem el.

\subsubsection{Statisztikai módszer}

Az adatok elemzését SPSS for windows programmal végeztem. A leíró statisztika mellet (pl.: átlag, szórás), ún. „K-Means” klaszteranalízist használtam, hogy a 10 sportelköteleződés forrásból sport-elköteleződés profilokat hozzak létre. A szakirodalom szerint a módszert gyakran használják a változók csoportba rendezéséhez, melynek számát én 
magam tudtam megadni. Korábbi kutatások három sport-elköteleződés profilt javasoltak, így elemzésemben is e szerint jártam el (Raedeke, 1997; Weiss és Weiss, 2003). A létrehozott klasztereket, összehasonlítottam, a kétféle elköteleződés típussal is a kapott csoportok igazolása érdekében, melyhez ANOVA elemzést alkalmaztam. A kapott profilokat végül tovább elemeztem és megnéztem, hogy a pszichológiai skálák (élettel való elégedettség, jövőorientáció, aspirációk, egészségattitüdök), milyen hatással vannak ezekre a profilokra. Ehhez MANOVA elemzést alkalmaztam, melyet szignifikáns értéknél egyváltozós elemzés követett Tukey post-hoc teszttel. A szignifikancia elfogadható értéke 0,05 volt.

\subsubsection{Eredmények}

\section{Klaszteranalízis}

Az adatok elemzését a sport-elköteleződés profilok meghatározásával kezdtem. A “kmeans" módszerrel elvégzett elemzéshez a sport-elköteleződés tíz forrását használtam fel. A jobb eredmény érdekében az ún. z-score és a nyers adatok is interpretálásra kerültek. A tíz felhasznált változó végül három klasztert azonosított (18. táblázat). A jobb értelmezhetőség kedvéért a z-score alapján ábrázoltam is a három sport-elköteleződés profilt (15. ábra). A csoportok közötti különbségek meghatározására a z - érték 0,5 különbségét vettem alapul, melynek köszönhetően meg tudtam állapítani, hogy az adott érték alacsonyabb vagy magasabb szintnek számít-e a kapott profiloknál. Ezek alapján a következő profilokat kaptam:

Az első klaszter a kötelezettségböl sportolók $(\mathrm{n}=162)$ nevet viseli. Ök azok, akik alacsonyabb szinteket értek el a legtöbb felhasznált változónál, azonban az egyéb prioritások átlagértéke ebben a csoportban volt a legmagasabb a többi csoporthoz képest (18. táblázat; 15. ábra). Ha mélyebben megnézzük az eredményeket, azt láthatjuk, hogy a tíz változóból hétben a minta átlagánál alacsonyabb pontszámot értek el a csoportban szereplő sportolók. Az egyéb prioritásokon túl a személyes befektetés - veszteség és a közösségi kényszer átlagértéke is magasabb pontszámokat mutatott a profilnál. Úgy tűnik tehát, hogy az ilyen profilú sportolóknál a sport iránti elköteleződést a kötelezettség és a kényszer uralja.

A második klaszter neve alulmotivált sportolók $(\mathrm{n}=65)$ lett. Ök azok, akik negatív élményként élik meg a sportágukat. Ahogy a táblázatból és az ábrán is láthatjuk, ők alacsony pontszámot értek el valamennyi skálán (kivéve az egyéb prioritások). Sajnos ők vannak kitéve legjobban a kiégésnek és a lemorzsolódásnak a mintában. 
Az utolsó klaszterhez tartoztak legtöbben, szám szerint 299-en, és ők a lelkes sportolók, akik pozitív élményként élik meg a sportágukat, ezért valamennyi változónál magas értékeket értek el (kivéve az egyéb prioritások). Valamennyi forrás pontértéke átlag fölötti eredményt mutat. A közösségi kényszer, valamint az egyéb prioritások értek el egyedül alacsonyabb eredményt a több csoporthoz viszonyítva. Ebből is látszik, hogy ezek az atléták magas elköteleződéssel rendelkeznek. 
18. táblázat. Átlag, szórás, z-érték és F értékek a klaszter csoportok számára

\begin{tabular}{|c|c|c|c|c|c|c|c|c|c|c|}
\hline & \multicolumn{3}{|c|}{$\begin{array}{c}\text { 1. Klaszter } \\
\text { Kötelezettségből } \\
\text { sportolók }(\mathrm{n}=162)\end{array}$} & \multicolumn{3}{|c|}{$\begin{array}{c}\text { 2. Klaszter } \\
\text { Alulmotivált sportolók } \\
(\mathrm{n}=65)\end{array}$} & \multicolumn{3}{|c|}{$\begin{array}{c}\text { 3. Klaszter } \\
\text { Lelkes sportolók }(\mathrm{n}=299)\end{array}$} & \multirow[b]{2}{*}{$\mathrm{F}-\mathrm{Test}$} \\
\hline & Átlag & Szórás & $\begin{array}{c}\text { Z- } \\
\text { Score }\end{array}$ & Átlag & Szórás & Z-Score & Átlag & Szórás & $\begin{array}{c}\text { Z- } \\
\text { Score }\end{array}$ & \\
\hline Sportélvezet & 4,24 & 0,75 & $-0,42$ & 3,95 & 0,91 & $-0,86$ & 4,79 & 0,33 & 0,41 & $83,65 * * *$ \\
\hline Értékes lehetőségek & 3,55 & 0,79 & $-0,38$ & 2,15 & 0,80 & $-1,74$ & 4,54 & 0,51 & 0,58 & $407,60 * * *$ \\
\hline $\begin{array}{l}\text { Személyes-befektetése - } \\
\text { mennyiség }\end{array}$ & 4,05 & 0,60 & $-0,29$ & 2,72 & 0,93 & $-1,84$ & 4,78 & 0,34 & 0,56 & $434,082 * * *$ \\
\hline $\begin{array}{l}\text { Személyes-befektetése - } \\
\text { veszteség }\end{array}$ & 3,53 & 0,68 & $-0,05$ & 2,11 & 0,92 & $-1,40$ & 3,93 & 0,97 & 0,33 & $114,96 * * *$ \\
\hline Egyéb prioritások & 2,94 & 0,93 & 0,42 & 2,51 & 1,00 & $-0,05$ & 2,36 & 0,83 & $-0,22$ & $23,16 * * *$ \\
\hline Törekvés a fejlődésre - képesség & 4,01 & 0,54 & $-0,43$ & 3,11 & 0,87 & $-1,64$ & 4,78 & 0,29 & 0,59 & $372,73 * * *$ \\
\hline Törekvés a fejlődésre - közösség & 3,81 & 0,58 & $-0,33$ & 2,58 & 0,85 & $-1,78$ & 4,58 & 0,40 & 0,57 & $406,57_{* * *}$ \\
\hline Közösségi kényszer & 3,24 & 0,94 & $-0,01$ & 1,85 & 0,85 & $-1,28$ & 3,55 & 0,97 & 0,28 & $87,70 * * *$ \\
\hline Közösségi támogatás - érzelmi & 3,53 & 0,90 & $-0,43$ & 2,79 & 0,92 & $-1,22$ & 4,42 & 0,60 & 0,50 & $162,86 * * *$ \\
\hline Közösségi támogatás - informális & 3,31 & 0,75 & $-0,32$ & 2,25 & 0,78 & $-1,47$ & 4,06 & 0,63 & 0,50 & $205,56 * * *$ \\
\hline
\end{tabular}




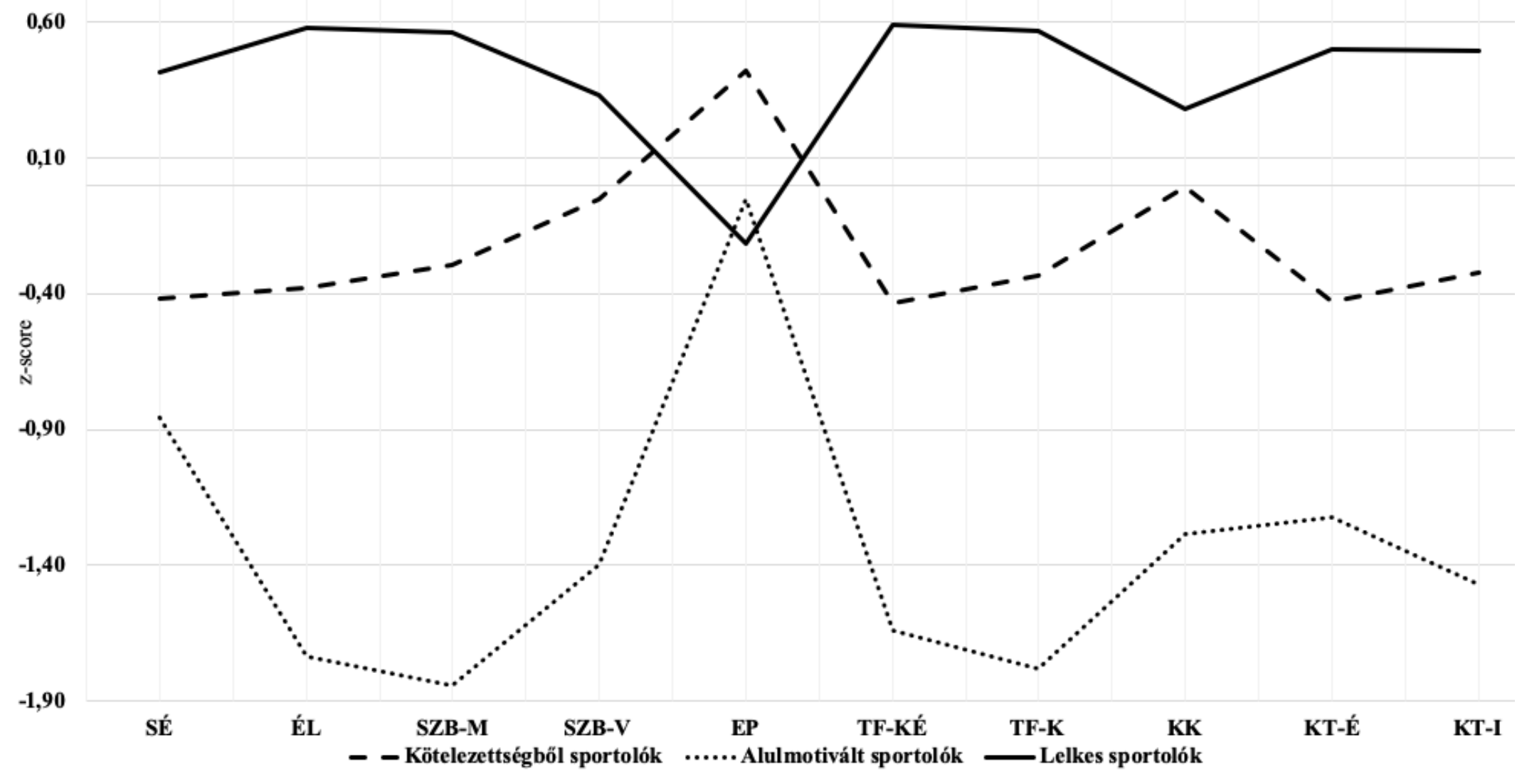

15. ábra. A három sport-elkötelezödés profil a z-score alapján

Megjegyzés: SÉ= Sportélvezet; ÉL=Értékes lehetőségek; SZB-M=Személyes befektetések - mennyiség; SZB-V=Személyes befektetésesek - veszteség; EP=Egyéb prioritások; TF-KÉ=Törekvés a fejlődésre - képesség; TF-K=Törekvés a fejlődésre - közösség; KK=közösségi kényszer; KT-É=Közösségi támogatás - érzelmi; KT-I=Közösségi támogatás - informál 
Ellenőrzés képpen megvizsgáltam a klaszteranalízisnél kapott csoportokat, hogy a kétféle elköteleződés típus milyen kapcsolatot mutat a három profil között. Az ANOVA elemzés szerint a lelkes elkötelezödés $[\mathrm{F}(2,523)=252,64 ; \mathrm{p}<0,001]$ szignifikánsan eltért a 3 csoport között. A Tukes post-hoc teszt pedig megmutatta, hogy a lelkes atléták szignifikánsan magasabb $(\mathrm{p}<0,05)$ lelkes elkötelezödéssel rendelkeznek, mint a kötelezettségböl sportolók és az alulmotivált sportolók. Szignifikánsan különbözik az eröltetett elkötelezödés $[\mathrm{F}(2,523)=52,210 ; \mathrm{p}<0,001]$ is a három profil között. A post-hoc teszt pedig megmutatta, hogy az alulmotivált sportolók $(\mathrm{p}<0,05)$ rendelkeznek a legmagasabb erőltetett értékkel. A két eredmény alátámasztotta a kapott profilok megbízhatóságát.

\section{Csoportok közötti különbségek}

A kutatás következő lépésében megvizsgáltam a három klaszter csoport különbségeit, hogy a szubjektív jólét, jövőorientáció, aspiráció és egészségattitüd miben tér el a sportelköteleződés profilok között. A többváltozós MANOVA elemzés megmutatta, hogy a csoportok között szignifikáns hatás érvényesül (Pillai's trace $=0,24, \mathrm{~F}(10,1040$ )=14,87, p<0,01, ךp2=0,12), majd az ezt követő egyváltozós elemzések leírták, hogy valamennyi skála szignifikánsan eltért a csoportok között, melynek hatásnagysága 2\% és $11 \%$ között mozgott (19. táblázat). Elemzésemet a post-hoc teszttel zártam, ahol kiderült, hogy az élettel való elégedettség, jövőorientáltság, intrinzik aspiráció szignifikánsan magasabb volt a lelkes sportolóknál ( $\mathrm{p}<0,05)$, mint a kötelezettségböl és az alulmotivált sportolóknál. A kötelezettségből sportolók ( $\mathrm{p}<0,05)$ szignifikánsan magasabb értéket értek el az extrinzik aspirációk és egészségattitüdük terén. 
19. táblázat. Az elkötelezödés profilok egészségpszichológiai különbségei

\begin{tabular}{|c|c|c|c|c|c|c|c|c|}
\hline \multirow[b]{3}{*}{ Változók } & \multirow[b]{3}{*}{$\mathrm{F}(2,523)$} & \multirow[b]{3}{*}{$\eta_{\mathrm{p} 2}$} & \multicolumn{6}{|c|}{ Klaszter } \\
\hline & & & \multicolumn{2}{|c|}{$\begin{array}{l}\text { Kötelezettségből } \\
\text { sportolók (n=162) }\end{array}$} & \multicolumn{2}{|c|}{$\begin{array}{l}\text { Alulmotivált } \\
\text { sportolók (n=65) }\end{array}$} & \multicolumn{2}{|c|}{$\begin{array}{l}\text { Lelkes sportolók } \\
(\mathrm{n}=299)\end{array}$} \\
\hline & & & Átlag (szórás) & $\mathrm{z}$ & Átlag (szórás) & $\mathrm{Z}$ & Átlag (szórás) & $\mathrm{z}$ \\
\hline Élettel való elégedettség & $32,47 * * *$ & 0,11 & $4,68(1,36)$ & $-0,40$ & $4,80(1,59)$ & $-0,31$ & $5,58(1,03)$ & 0,28 \\
\hline Jövőorientáció & $31,99 * * *$ & 0,11 & $3,38(0,63)$ & $-0,41$ & $3,47(0,73)$ & $-0,27$ & $3,83(0,56)$ & 0,28 \\
\hline Intrinzik aspirációk & $16,61 * * *$ & 0,06 & $4,37(0,58)$ & $-0,24$ & $4,44(0,59)$ & $-0,13$ & $4,64(0,40)$ & 0,16 \\
\hline Extrinzik aspirációk & $21,28 * * *$ & 0,07 & $4,04(0,91)$ & 0,24 & $3,32(0,78)$ & $-0,67$ & $3,87(0,65)$ & 0,01 \\
\hline Egészségattitüdök & $4,98 * *$ & 0,02 & $3,55(0,89)$ & 0,20 & $3,35(0,88)$ & $-0,02$ & $3,27(0,90)$ & $-0,10$ \\
\hline
\end{tabular}




\subsubsection{Megbeszélés}

A vizsgálat célja az volt, hogy a sport-elköteleződés forrásai alapján feltárjam, hogy milyen profilú sportolók alkotják mintámat. Megvizsgáltam továbbá, hogy az egészségpszichológiai változók, hogyan térnek el a csoportok között.

A szakirodalommal összhangban három profilt tártam fel (Raedeke, 1997; Wiess és Wiess, 2003). A lelkes sportolók a testmozgás pozitív oldalát képviselik, melyhez hasonlót találhatunk a korábbi kutatásokban is. Raedeke (1997) tanulmányában „lelkes úszóknak” nevezte a hasonló tulajdonságúak csoportját, míg Weiss és Weiss (2003) a sportágak irányából megközelítve "vonzó sportágaknak” nevezte a vizsgáltomban szereplő hasonló profilt. A lelkes sportolók jellemzője, hogy magasabb élvezettel, befektetésekkel, lehetőségekkel célokkal és támogatásokkal rendelkeznek a többi sportolóhoz képest. Ez a csoport azért sportol, mert szeret és pozitív élményként tekint rá. Ezért ők sokkal többet is fektetnek a sportágukba és nem szeretnék, ha ez a befektetés elveszne, így ez is a sportban tartja öket. A lelkes sportolók magasabb törekvés a fejlődésre - képesség értékkel rendelkeztek, mint a törekvés a fejlödésre - közösség (igaz mind a kettő magas). Ez talán arra engedhet következtetni, hogy a sportolók elsősorban inkább a saját eredményeik javítását, saját fejlődésüket tarják szem előtt mintsem mások legyőzését. Érdekes eredmény mutatott a közösségi támogatás szintje, hiszen mind a kettő (informális, érzelmi) magas szintet mutatott, de az érzelmi támogatás minimálisan magasabb volt ennél a profilnál. Úgy tünik, hogy a másoktól érkező támogatások, törődések talán fontosabb számunkra, mint az anyagi vagy a személytelen támogatások. Weiss és Weiss (2003) hasonló megállapításra jutott a közösségi változókat vizsgálva. Ők azt találták, hogy a közeli barátok és a családtagok voltak a legfontosabbak a magasabban elköteleződött sportolók számára. A közösségi kényszer és az egyéb prioritások alacsony szinten volt a lelkes sportolóknál és az egyéb prioritások is itt voltak a legalacsonyabbak. Ez várható volt, hiszen ők azok, akiknek a sportol a legfontosabb, így nem valószínű, hogy más hobbit is üznének mellette. A közösségi kényszernek kisebb szerepe volt, mint más csoportokban. Korábbi kutatások azt mutatják, hogy a közösség által elvárt normák inkább a kényszerből mintsem az élvezetből történő sportolást segítik (Scanlan és mtsai, 2016; Sousa és mtsai, 2007; Wilson és mtsai, 2004).

A kényszerből sportolók volt a második legnépesebb csoport. Ök azok, akik a lelkes és az alulmotivált sportolói csoportok közé estek. A profil hasonlóságot mutatott Raedeke (1997) „közömbös” profilú úszóihoz és Weiss és Weiss (2003) „sebezhető” profilú 
sportolóihoz. Úgy vélem, hogy ezeknek a sportolóknak fontos a sport, lehetőségeket is látnak benne, az egyéni fejlődés fontosabb számukra, sőt hajlandók energiát is bele fektetni. Rájuk azonban az is jellemző, hogy inkább folytatják a sportolását akkor is, ha már nem annyira szeretik, csak ne vesszen el a belefektetett idő és energia. Valamint számukra már megnő a jelentősége a különböző alternatíváknak, így a tanulás vagy egyéb hobbik komoly visszatartó erővel bírhatnak. A közösségi kényszer kiemelkedik náluk, hiszen a mások általi elvárások révén az egyén a sportágánál maradhat még akkor is, ha kevésbé szereti azt vagy más elfoglaltságok befolyásolják döntését. Fontost még megemlíteni, hogy a személyes befeketések-veszteség, egyéb prioritások, közösségi kényszer az eröltetett elkötelezödés forrásának mondhatók, minthogy láthattuk az előző fejezetben, valamint a szakirodalomban (Scanlan és mtsai, 2016). Ugyanakkor valamilyen szinten ezek is hozzájárulhatnak az elköteleződés fenntartásához, még akkor is, ha esetleg kényszerről beszélünk.

A legkevésbé elkötelezett csoport az alulmotivált sportolók voltak. Ők azok a sportolók, akik kevés érdeklődést mutattak a sportáguk iránt, annak ellenére, hogy valamelyest élvezik a sportágukat, de számukra viszonylag magas a lemorzsolódás kockázata. Az eredmények szerint az alternatívák fontos szerepet játszanak az alulmotivált sportolók számára. Hasonló profilokkal korábbi tanulmányokban is találkozhatunk, például Raedeke (1997) empirikus kutatásában is talált hasonló sportolói profilt.

A kapott profilok jól ábrázolják a mintám elköteleződési tulajdonságait és a csoportok megfelelő lehetőséget nyújtanak összehasonlítások megállapítására is. Ezért elemzésem következő részében megvizsgáltam a csoportok közötti egészségpszichológiai különbségeket. A szakirodalom keveset ír a sport iránti elkötelezettség kapcsolatáról az egészségmagatartás változóival. Ezért megvizsgáltam, hogy vannak-e különbségek a kapott sport-elköteleződés profilok között. A sport egészséget védő szerepe miatt feltételeztem, hogy a magasabb egészségpszichológiai értékek inkább a lelkes sportolókra jellemzők, akik nagyobb elköteleződést mutatnak sportáguk iránt. Ez a feltételezés részben be is igazolódott, hiszen az élettel való elégedettség, a jövőbeli célok (mint láthattuk az előző elemzésben) és az intrinzik aspirációk is szignifikánsan magasabbak voltak a lelkes sportolók esetén. Az eredmény több mindennel is kapcsolatban állhat. Elöször is amint már említem, talán köze lehet a sport egészséget védő szerepének. Hiszen úgy tünik, hogy ezek a sportolók azáltal, hogy többet sportolnak tudatosabban is tervezik életüket, így világosabb célokkal rendelkezhetnek és talán szubjektív jóléltük is nagyobb lehet. A lelkes sportolók továbbá nagyobb jelentőséget tulajdonítanak az intrinzik értékeknek (pl.: sportélvezet). Gurková és munkatársai (2003) tanulmányára is hasonló dolgok a jellemzőek. Szerinte a magasabb belső 
motiváció pozitívabb mentális tulajdonságokkal bír (pl.: alacsonyabb depresszió, magasabb önértékelés stb.). Sheehan, Herring és Campbell (2018) longitudinális tanulmánya szerint pedig az intrinzik motivációval sportolók magasabb elégedettséggel számoltak be az alapvető pszichológiai igényekről.

Az extrinzik aspiráció a kötelezettségből sportolóknál volt szignifikánsan magasabb. Úgy tünik, hogy számukra inkább fontos, hogy mások előtt kitünjenek és elismerést kapjanak a társaiktól, mintsem a pénz és a hírnév. Nem meglepő módon az extrinzik aspirációk az alacsony szubjektív jólettel is kapcsolatban vannak (Sheldon és mtsai, 2004; Lee és mtsai, 2010), mely ebben a tanulmányban is megfigyelhető, hiszen a kötelezettségböl sportolóknál volt a legalacsonyabb az élettel való elégedettség pontszáma. Habár alacsony hatásértékkel jelent meg az egészségattitüd, mint szignifikáns változó, de úgy néz ki a kötelezettségböl sportolóknál fontos szerepet játszhat. Kutatásomban az egészség, mint külső tényező jelenik meg, mely talán annak köszönhető, hogy vizsgált serdülők azért sportolnak, hogy egészségesek legyen vagy hogy testalkatuk változzon és nem azért, mert szeretik az adott sportágat. Molanorouzi (2014) és munkatársai is hasonló megállapításra jutott. Azonban egyes kutatók szerint az egészség, mint intrinzik hajtóerő jelenik meg a motivációban (Lavigne és mtsai, 2009; Puante és Anshel, 2010). Így eredményeim azt jelenthetik, hogy csak az egészségért sportolni kötelezettséggel járhat, ami nem biztos, hogy hosszú távú elköteleződéshez vezet. A szakirodalomban van arra példa, hogy az extrinzik motiváció idővel a sportág megszeretése révén belsővé vált (Reinboth és Duda, 2006). Továbbá hiába kevésbé előtétezettekre jellemző az egészségért való sportolás mégis pozitív hatása van a sport részvételre.

A vizsgálatom megmutatta, hogy a lelkes sportolók jobb egészségpszichológiával rendelkezhetnek, mint a többi csoport sportolói, ugyanakkor a kényszerből történő sportolás is lehet pozitív cél (pl.: egészséges életmód). A profilok alapján egyérletmü, hogy az élvezet az egyik legfontosabb valamennyi csoportnál, hiszen az ösztönözheti a fiatalokat, hogy sportoljanak. Ezek mellett valamilyen jutalomra vagy elvárásra is szüksége van a csoportoknak, mely extrinzik, de azok is segíthetik a fiatalokat az egészséges életmód kialakításában. A serdülöknél nem lehet kizárni az alternatívákat (pl.: iskola, hobi stb.), de az ilyen tevékenységek kontrollálása megakadályozhatja a sportolók lemorzsolódását.

Ezek alapján megállapíthatom, hogy hipotézisem a sport-elköteleződés és az egészségpszichológiai változókról részben igazolódott be $(\mathrm{H} 9)$, hiszen a lelkes sportolók magasabb szubjektív jólléttel, jövőorientációval és belső aspirációkkal és a kényszerből sportolók magasabb extrinzik aspirációval rendelkeznek. Az egészségattitüdök is a 
kényszerrel áll kapcsolatban, amely talán egy újabb forrása is lehet az eröltetett elkötelezödésnek.

\subsubsection{A tökéletességre törekvés és a sport-elköteleződés kapcsolata}

A fejezetben célom volt megnézni, a Frost és munkatársai (1990) által leírt perfekcionizmusdimenziók milyen kapcsolatban állnak a Scanlan és munkatársai által (2016) meghatározott sport-elköteleződési típusokkal, illetve forrásokkal, a nemmel, valamint bizonyos sportolási jellemzőkkel (pl. sportolási szint, sportsérülés előfordulása). Úgy hiszem, a tökéletességre törekvés fontos szerepet tölthet be a sportolók életében, mely megjelenhet a sport iránti elköteleződésükben is. Az elemzés a második adatfelvétel $(n=344)$ elemzésével készült a sport-elköteleződés-2 és a multidimenzionális perfekcionizmus skálák felhasználásával.

\subsubsection{Statisztikai módszer}

Az elemzés során a változók közötti kapcsolatok erősségének mérésére Pearson korrelációs együtthatókat számoltam. A sportolók perfekcionizmus-dimenziók által jellemzett csoportjait klaszteranalízissel, míg a klaszterek közötti eltéréseket Khí-négyzet próbával és variancia-analízissel teszteltem.

\subsubsection{Eredmények}

A 20. táblázatban a perfekcionizmus alskáláinak leíró statisztikája látható a nem és sportolási jellemzők tükrében. Három esetben találtam szignifikáns nemi eltéréseket: a személyes elvárások, a szülooi elvárások és a szülői kritika értékeiben: mindhárom esetben a fiúk pontszáma bizonyult magasabbnak. A sportoló fiúk elé tehát szüleik magasabb elvárásokat támasztanak, de több kritika is éri őket, és önmaguktól is többet várnak el, mint a lányok. A többi esetben is magasabb értékeket kaptam, de az eltérések nem haladták meg a statisztikai kritériumot. A sportolási szintnek megfelelően azok, akik nemzetközi vagy országos szinten versenyeznek, valamennyi alskálán magasabb pontszámot értek el, de két esetben nem volt az eltérés szignifikáns: a viselkedés miatti kételyek és az összeszedettség terén. A magasabb szinten versenyző sportolók tehát nemcsak a saját és a szülői elvárásoknak igyekeznek jobban megfelelni, hanem a hibák miatti aggodalom is jellemzőbb rájuk. A viselkedés miatti kételyek és az összeszedettség itt sem mutatott eltérést, csakúgy, mint a harmadik esetben; azok a sportolók azonban, akiknek már volt sportsérülése, nagyobb mértékủ személyes és szülői elvárásokról és kritikáról számoltak be. 
20. táblázat. A perfekcionizmus alskáláinak leíró statisztikája a nem és sportolási jellemzök tükrében

\begin{tabular}{|c|c|c|c|c|c|c|}
\hline & $\begin{array}{l}\text { Hibák miatti } \\
\text { aggodalom } \\
\text { Átlag (szórás) }\end{array}$ & $\begin{array}{c}\text { Személyes } \\
\text { elvárások } \\
\text { Átlag (szórás) }\end{array}$ & $\begin{array}{l}\text { Szülői elvárások } \\
\text { Átlag (szórás) }\end{array}$ & $\begin{array}{l}\text { Szülői kritika } \\
\text { Átlag (szórás) }\end{array}$ & $\begin{array}{c}\text { Viselkedés miatti } \\
\text { kételyek } \\
\text { Átlag (szórás) }\end{array}$ & $\begin{array}{c}\text { Összeszedettség } \\
\text { Átlag (szórás) }\end{array}$ \\
\hline \multicolumn{7}{|l|}{ Nem } \\
\hline Fiú & $2,72(0,92)$ & $3,67(0,70)$ & $2,92(0,91)$ & $2,39(0,99)$ & $3,19(0,86)$ & $3,92(0,70)$ \\
\hline Lány & $2,55(0,96)$ & $3,38(0,80)$ & $2,54(1,00)$ & $1,95(0,94)$ & $3,14(0,89)$ & $3,82(0,89)$ \\
\hline t-érték & 1,54 & 3,43 & 3,57 & 4,11 & 0,49 & 2,10 \\
\hline Szignifikancia & $p=0,12$ & $\mathbf{p}=\mathbf{0 , 0 0 1}$ & $\mathbf{p}=\mathbf{0 , 0 0 0}$ & $\mathbf{p}=\mathbf{0 , 0 0 0}$ & $p=0,62$ & $p=0,27$ \\
\hline \multicolumn{7}{|l|}{ Versenyzés szintje } \\
\hline Nemzetközi/országos & $2,70(0,95)$ & $3,66(0,69)$ & $2,77(0,97)$ & $2,21(1,02)$ & $3,21(0,84)$ & $3,91(0,76)$ \\
\hline Helyi/hobbi & $2,47(0,93)$ & $3,20(0,85)$ & $2,54(0,99)$ & $1,97(0,88)$ & $3,05(0,92)$ & $3,75(0,91)$ \\
\hline t-érték & 2,13 & 5,46 & 2,12 & 2,21 & 1,67 & 1,76 \\
\hline Szignifikancia & $\mathbf{p}=\mathbf{0 , 0 3}$ & $\mathbf{p}=\mathbf{0 , 0 0 0}$ & $\mathbf{p}=\mathbf{0 , 0 3}$ & $\mathbf{p}=\mathbf{0 , 0 3}$ & $\mathrm{p}=0,10$ & $\mathrm{p}=0,08$ \\
\hline \multicolumn{7}{|l|}{ Sportsérülése volt-e? } \\
\hline Igen & $2,72(0,97)$ & $3,64(0,74)$ & $2,78(0,99)$ & $2,23(1,01)$ & $3,19(0,87)$ & $3,93(0,76)$ \\
\hline Nem & $2,50(0,91)$ & $3,32(0,80)$ & $2,57(0,97)$ & $1,98(0,91)$ & $3,13(0,89)$ & $3,77(0,88)$ \\
\hline t-érték & 2,16 & 3,84 & 2,04 & 2,36 & 0,62 & 1,82 \\
\hline Szignifikancia & $p=0,03$ & $p=0,000$ & $p=0,04$ & $\mathbf{p}=\mathbf{0 , 0 2}$ & $\mathrm{p}=0,54$ & $\mathrm{p}=0,07$ \\
\hline
\end{tabular}


A 21. táblázat a korrelációelemzés eredményeit mutatja be, amelyek a sport iránti elköteleződés és a perfekcionizmus alskálái közötti kétoldalú kapcsolatok erösségét jelzik. A hibák miatti aggodalom nemcsak az eröltetett elkötelezödéssel mutatott pozitív kapcsolatot, hanem az értékes lehetöségekkel és egyéb prioritásokkal, valamint a közösségi kényszerrel is. A személyes elvárások alskálán elért pontszám egy kivétellel (eröltetett elkötelezödés) pozitív korrelációban áll az elköteleződés alskáláival. A legerősebbnek a törekvés a fejlődésre elnevezésü két változóval (képesség, közösségi) bizonyult a kapcsolat. A szülői elvárások és kritika a legerősebb összefüggést az erőltetett elköteleződéssel mutatta, ezen kívül mindkét változóval pozitívan korrelált a közösségi kényszer, a személyes befektetés - veszteség is, ugyanakkor negatív kapcsolat igazolható a sportélvezettel. A viselkedés miatti kételyek alskála pozitívan kapcsolódott az erőltetett elkötelezödéshez, az egyéb prioritásokhoz, valamint a személyes befektetés - veszteség forráshoz. Végül az összeszedettség az eröltetett elkötelezödéssel negatív, a lelkes elkötelezödéssel pedig pozitív korrelációt jelzett, és a személyes elvárásokhoz hasonlóan itt is pozitív volt a kapcsolat a sportélvezettel, a közösségi támogatás és a fejlödésre való törekvés mindkét formájával. A perfekcionizmus skála összpontszámát tekintve a legerősebb kapcsolat az eröltetett elkötelezödéssel jelentkezett ( $\mathrm{r}=$ 0,31, p < 0,001), míg a lelkes elkötelezödéssel, a fejlödésre való törekvéssel, a sportélvezettel és a közösségi támogatással nem volt szignifikáns a kapcsolat. 
21. táblázat. A sport iránti elkötelezödés és a perfekcionizmus kapcsolatainak vizsgálata korreláció-elemzéssel

\begin{tabular}{|c|c|c|c|c|c|c|c|}
\hline & $\begin{array}{l}\text { Hibák miatti } \\
\text { aggodalom }\end{array}$ & Személyes elvárások & $\begin{array}{l}\text { Szülöi } \\
\text { elvárások }\end{array}$ & Szülői kritika & $\begin{array}{c}\text { Viselkedés } \\
\text { miatti } \\
\text { kételyek }\end{array}$ & Összeszedettség & $\begin{array}{l}\text { Perfekcionizmus } \\
\text { összpontszám }\end{array}$ \\
\hline Lelkes elköteleződés & 0,03 & $0,28 * * *$ & $-0,06$ & $-0,10^{*}$ & 0,02 & $0,27 * * *$ & 0,10 \\
\hline $\begin{array}{l}\text { Erőltetett } \\
\text { elköteleződés }\end{array}$ & $0,31 * * *$ & 0,03 & $0,30 * * *$ & $0,40 * * *$ & $0,23 * * *$ & $-0,13^{*}$ & $0,31 * * *$ \\
\hline Sportélvezet & 0,03 & $0,15 * *$ & $-0,12 *$ & $-0,11^{*}$ & 0,05 & $0,18 * * *$ & 0,03 \\
\hline Értékes lehetőségek & $0,14^{*}$ & $0,35 * * *$ & 0,10 & 0,06 & 0,08 & $0,16 * *$ & $0,21 * * *$ \\
\hline Egyéb prioritások & $0,23 * * *$ & 0,01 & 0,09 & $0,23 * * *$ & $0,20 * * *$ & $-0,06$ & $0,18 * *$ \\
\hline $\begin{array}{l}\text { Személyes } \\
\text { befektetések - }\end{array}$ & & & & & & & $0,23 * * *$ \\
\hline $\begin{array}{l}\text { veszteség } \\
\text { Személyes } \\
\text { befektetések - }\end{array}$ & $0,14 *$ & $0,30 * * *$ & $0,20 * * *$ & $0,13 *$ & $0,11 *$ & 0,05 & $0,17 * *$ \\
\hline mennyiség & 0,06 & $0,32 * * *$ & 0,05 & 0,02 & 0,04 & $0,25 * * *$ & \\
\hline $\begin{array}{l}\text { Törekvés a fejlödésre - } \\
\text { képesség }\end{array}$ & 0,03 & $0,37 * * *$ & $-0,05$ & $-0,14 * *$ & 0,03 & $0,27 * * *$ & 0,10 \\
\hline Közösségi kényszer & $0,17 * * *$ & $0,26 * * *$ & $0,27 * * *$ & $0,22 * * *$ & 0,09 & $0,11 *$ & $0,28 * * *$ \\
\hline $\begin{array}{l}\text { Közösségi támogatás - } \\
\text { érzelmi }\end{array}$ & $-0,05$ & $0,20 * * *$ & $-0,02$ & $-0,15^{* *}$ & $-0,05$ & $0,19 * * *$ & 0,01 \\
\hline $\begin{array}{l}\text { Közösségi támogatás - } \\
\text { informális }\end{array}$ & $-0,01$ & $0,18 * * *$ & $-0,01$ & 0,02 & $-0,05$ & $0,17 * *$ & 0,07 \\
\hline $\begin{array}{l}\text { Törekvés a fejlődésre - } \\
\text { közösség }\end{array}$ & $0,13 *$ & $0,39 * * *$ & $0,12 *$ & 0,03 & 0,04 & $0,21 * * *$ & $0,22 * * *$ \\
\hline
\end{tabular}


A továbbiakban klaszteranalízissel a sportolókat kategorizáltam a perfekcionizmus alskálái közötti összefüggések alapján. A K-közép algoritmusú klaszteranalízis eredményeit a 22. táblázat mutatja be, mely szerint három klasztert azonosítottam. A klaszteranalízis azáltal hoz létre csoportokat, hogy a csoportok közötti varianciát maximalizálja, míg a csoporton belüli varianciát minimalizálja. Ennek megfelelően variancia-analízis (ANOVA) segítségével határoztam meg az ideális klaszterszámot. A táblázatban az egyes klaszterekhez tartozó változók nyers és az ún. z-score (standardizált) átlagértékeit, valamint az F-értékeket láthatjuk.

22. táblázat. A sportolók klaszterei a perfekcionizmus alskálák pontszámai alapján

\begin{tabular}{|c|c|c|c|c|}
\hline & $\begin{array}{c}\text { 1. klaszter } \\
\text { Átlag (szórás) } \\
\text { z-score } \\
\end{array}$ & $\begin{array}{c}\text { 2. klaszter } \\
\text { Átlag (szórás) } \\
\text { z-score } \\
\end{array}$ & $\begin{array}{c}\text { 3. klaszter } \\
\text { Átlag (szórás) } \\
\text { z-score }\end{array}$ & $\begin{array}{c}\text { F-érték } \\
\text { (ANOVA) }\end{array}$ \\
\hline Hibák miatti aggodalom & $\begin{array}{c}3,46(0,63) \\
0,88\end{array}$ & $\begin{array}{c}1,69(0,45) \\
-0,97\end{array}$ & $\begin{array}{c}2,64(0,75) \\
0,03\end{array}$ & $219,5^{*}$ \\
\hline $\begin{array}{l}\text { Viselkedés miatti } \\
\text { kételyek }\end{array}$ & $\begin{array}{c}3,68(0,63) \\
0,59\end{array}$ & $\begin{array}{c}2,33(0,63) \\
-0,94\end{array}$ & $\begin{array}{c}3,41(0,73) \\
0,29\end{array}$ & $126,3^{*}$ \\
\hline Szülői elvárások & $\begin{array}{c}3,66(0,62) \\
0,99\end{array}$ & $\begin{array}{c}2,04(0,71) \\
-0,65\end{array}$ & $\begin{array}{c}2,32(0,73) \\
-0,37\end{array}$ & $180,3^{*}$ \\
\hline Szülői kritika & $\begin{array}{c}3,15(0,77) \\
1,05\end{array}$ & $\begin{array}{c}1,55(0,62) \\
-0,58\end{array}$ & $\begin{array}{c}1,65(0,56) \\
-0,48\end{array}$ & $215,3^{*}$ \\
\hline Személyes elvárások & $\begin{array}{c}3,75(0,58) \\
0,33\end{array}$ & $\begin{array}{c}2,84(0,76) \\
-0,83\end{array}$ & $\begin{array}{c}3,83(0,59) \\
0,43\end{array}$ & $81,4^{*}$ \\
\hline Összeszedettség & $\begin{array}{c}3,79(0,78) \\
-0,78\end{array}$ & $\begin{array}{c}3,50(0,85) \\
-0,43\end{array}$ & $\begin{array}{c}4,25(0,66) \\
0,48\end{array}$ & $27,9 *$ \\
\hline $\begin{array}{l}\text { Klaszter elnevezése } \\
\text { \%-os megoszlás }\end{array}$ & $\begin{array}{c}\text { Negatív } \\
\text { perfekcionisták } \\
33,6 \%\end{array}$ & $\begin{array}{c}\text { Nem } \\
\text { perfekcionisták } \\
31,6 \%\end{array}$ & $\begin{array}{c}\text { Pozitív } \\
\text { perfekcionisták } \\
34,8 \%\end{array}$ & \\
\hline
\end{tabular}

Az 1. klaszterbe a minta 33,6\%-a tartozott, és legfontosabb jellemzői a magas szülöi elvárások és kritika mellett a hibák miatti aggodalmak és a viselkedés miatti kételyek voltak. Ezért a klaszter a negatív perfekcionizmus elnevezést kapta. A 2. klaszter (ide a sportolók 31,6\%a tartozott) valamennyi perfekcionizmus alskála esetében a legalacsonyabb értékeket mutatta, ezért nekik a nem-perfekcionisták név jutott. Végül, a 3. klaszterre jellemző volt az összeszedettség és a személyes elvárások kiemelkedő pontszáma, ezért pozitív perfekcionistáknak neveztük el a csoportot, amibe a sportolók 34,8\%-át soroltuk. 
Az így kialakított klasztereket a nem és a sportolás bizonyos jellemzői (versenyszint és sportsérülés előfordulása) mentén is elemeztem, Khí-négyzet próbát alkalmazva a szignifikancia megállapításához (23. táblázat). Mindhárom esetben szignifikánsnak bizonyultak a klaszterek szerinti eltérések. A nemeket tekintve a fiúk között lényegesen többen tartoztak a negatív (45\%), míg a lányok közül a pozitív perfekcionistákhoz (39,3\%). A sportolási szint szerint a helyi szinten sportolók, illetve hobbisportolók között voltak a legtöbben (40,2\%) a nem-perfekcionisták. Ezzel szemben a nemzetközi vagy országos szintủ sportolók között többen voltak mind a negatív, mind pedig a pozitív perfekcionisták. Azok, akik nem számoltak be sportsérülésröl, döntően a nem-perfekcionisták közül kerültek ki, ezzel szemben a sportsérülést jelzők 40,5\%-a negatív perfekcionista.

23. táblázat. A klaszter-besorolás összefüggése a nemmel és sportolási jellemzökkel

\begin{tabular}{lcccc}
\hline & $\begin{array}{c}\text { Negatív } \\
\text { perfekcionisták }\end{array}$ & $\begin{array}{c}\text { Nem } \\
\text { perfekcionisták }\end{array}$ & $\begin{array}{c}\text { Pozitív } \\
\text { perfekcionisták }\end{array}$ & $\begin{array}{c}\text { Kí-négyzet } \\
\text { próba }\end{array}$ \\
\hline Nem (\%) & 45,0 & 27,5 & 27,5 & 12,5 \\
$\quad$ Fiúk & 26,6 & 34,1 & 39,3 & $(\mathbf{p}=\mathbf{0 , 0 0 2})$ \\
$\quad$ Lányok & 37,2 & 27,0 & 35,8 & \\
Versenyzés szintje (\%) & 27,6 & 40,2 & 32,3 & $(\mathbf{p}=\mathbf{0 , 0 3})$ \\
$\quad$ Nemzetközi/országos & & & & \\
$\quad$ Helyi/hobbi & 40,5 & 23,8 & 35,7 & 13,5 \\
Sportsérülése volt-e?(\%) & 25,3 & 40,5 & 34,2 & $(\mathbf{p = 0 , 0 0 1})$ \\
$\quad$ Igen & & &
\end{tabular}

Végül, az 24. táblázatban olvashatók a klaszter-besorolás szerint a sport iránti elkötelezettség típusait és forrásait jelentő alskálák átlagértékei és szórásai. Egy kivétellel (közösségi támogatás - informális) az eltérések variancia-analízissel szignifikánsnak bizonyultak. Míg a lelkes elkötelezödés legmagasabb pontszámait a pozitív perfekcionisták mutatták, addig az eröltetett elkötelezödés a negatív perfekcionistákra volt jellemző. A pozitív perfekcionisták érték el kimagaslóan a legmagasabb pontszámot ezen kívül a sportélvezet, az érzelmi közösségi támogatás, a törekvés a fejlödésre - képesség alskálák esetében is. A negatív perfekcionisták viszont az egyéb prioritások, a közösségi kényszer és a személyes befektetés veszteség alskálákon kaptak kiemelkedően magas pontszámot. A nem-perfekcionisták az értékes lehetöségek, az egyéb prioritások, a közösségi kényszer, a személyes befektetések, a törekvés a fejlödésre és az informális közösségi támogatás terén mutatták a legalacsonyabb pontszámot. A 
sportélvezet, a lelkes és az erőltetett elkötelezödés esetében a pontszámaik a két másik klaszter között helyezkedtek el.

24. táblázat. A klaszter-besorolás összefüggése a sport iránti elkötelezettség típusaival és forrásaival

\begin{tabular}{|c|c|c|c|c|}
\hline & $\begin{array}{c}\text { Negatív } \\
\text { perfekcionisták } \\
\text { Átlag (szórás) }\end{array}$ & $\begin{array}{c}\text { Nem } \\
\text { perfekcionisták } \\
\text { Átlag (szórás) }\end{array}$ & $\begin{array}{c}\text { Pozitív } \\
\text { perfekcionisták } \\
\text { Átlag (szórás) }\end{array}$ & $\begin{array}{c}\text { F-érték } \\
\text { (ANOVA) }\end{array}$ \\
\hline \multicolumn{5}{|l|}{ Típus } \\
\hline Lelkes elköteleződés & $3,85(0,84)$ & $3,70(1,18)$ & $4,20(0,90)$ & $8,05 * * *$ \\
\hline Erőltetett elköteleződés & $2,79(0,93)$ & $2,17(0,84)$ & $2,06(0,73)$ & $25,9 * * *$ \\
\hline \multicolumn{5}{|l|}{ Egyéni szintü források } \\
\hline Sportélvezet & $3,82(0,60)$ & $3,78(0,70)$ & $4,05(0,44)$ & $7,1 * *$ \\
\hline Értékes lehetőségek & $3,70(0,97)$ & $3,15(1,23)$ & $3,77(1,16)$ & $10,2 * * *$ \\
\hline Egyéb prioritások & $2,63(0,88)$ & $2,14(0,98)$ & $2,35(0,96)$ & $7,7 * *$ \\
\hline $\begin{array}{l}\text { Személyes befektetések - } \\
\text { veszteség }\end{array}$ & $3,48(0,88)$ & $2,94(1,24)$ & $3,31(1,21)$ & $8,7 * *$ \\
\hline $\begin{array}{l}\text { Személyes befektetések - } \\
\text { mennyiség }\end{array}$ & $4,18(1,05)$ & $3,88(1,05)$ & $4,29(0,90)$ & $6,2 * *$ \\
\hline $\begin{array}{l}\text { Törekvés a fejlődésre - } \\
\text { képesség }\end{array}$ & $4,19(0,73)$ & $4,06(0,97)$ & $4,44(0,68)$ & $6,5^{*}$ \\
\hline \multicolumn{5}{|l|}{$\begin{array}{l}\text { Közösségi szintü } \\
\text { források }\end{array}$} \\
\hline Közösségi nyomás & $3,58(1,03)$ & $2,82(1,16)$ & $3,15(1,18)$ & $16,3 * * *$ \\
\hline $\begin{array}{l}\text { Közösségi támogatás - } \\
\text { érzelmi }\end{array}$ & $3,65(0,96)$ & $3,65(1,19)$ & $3,95(1,09)$ & $3,0 *$ \\
\hline $\begin{array}{l}\text { Közösségi támogatás - } \\
\text { informális }\end{array}$ & $3,17(1,08)$ & $3,04(1,10)$ & $3,23(1,26)$ & 0,8 \\
\hline $\begin{array}{l}\text { Törekvés a fejlödésre - } \\
\text { közösség }\end{array}$ & $4,08(0,77)$ & $3,63(1,14)$ & $4,12(0,90)$ & $9,3^{*}$ \\
\hline
\end{tabular}

\subsubsection{Megbeszélés}

A fejezetben a perfekcionizmus állt a középpontban, melyben megvizsgáltam, a perfekcionizmus dimenzióinak összefüggését a sportolás egyes jellemzőivel, valamint a sport iránti elköteleződés elemeivel.

A motiváció és az elköteleződés a sportpszichológia igen fontos területe, hiszen ez az az attitüd, aminek megismerésével megelőzhetjük, hogy a sportolók abbahagyják sportpályafutásukat, illetve az összefüggések feltérképezésével növelhetjük a sportágukhoz való 
pozitív viszonyulásukat és azt, hogy több örömet találjanak a sportolásban, versenyzésben (Crane és Temple, 2015; Weiss és Weiss, 2006). A háttértényezők közül a perfekcionizmus vizsgálata különösen fontos, hiszen egy olyan személyiségjegyröl van szó, amely meglehetősen ellentmondásos; egyrészről a tökéletességre törekvés növelheti a fejlődés igényét, a sikerorientáltságot, a teljesítményt (Hill és Madigan, 2016; Stoeber és Otto, 2006). Ugyanakkor hajlamosíthat szorongásra, alkalmazkodási zavarokra, káros szerfogyasztásra, ami akár a teljesítményre is negatív hatással lehet (Dobos és Pikó, 2017; Dunkley és mtsai, 2003; Klibert és mtsai, 2015). A kétoldalú kapcsolatokat vizsgálva adataink is megerősítik ezt a kettősséget. A legtöbb esetben pozitív korrelációt találtam, különösen a magas személyes elvárások és az összeszedettség mutatott ilyen kapcsolatokat a legtöbb sport-elköteleződési alskálával. Ezek az összefüggések azt sugallják, hogy a perfekcionizmus eme dimenziói egyfajta drive-ot jelentenek a sportolók számára a fejlődésre, a személyes befektetésre, és növelik a sportélvezetét, a lelkes elkötelezödést. Más dimenziók az erőltetett elkötelezödés irányában hatnak: a szülői elvárások és kritika, valamint a hibák miatti aggodalom és a viselkedés miatti kételyek ezzel a sportelköteleződési típussal mutattak pozitív kapcsolatot. Nem véletlen, hogy az említett dimenziók a lelkes elkötelezödéssel egyáltalán nem, vagy mint a szülöi kritika, egyenesen negatív korrelációt eredményeztek. Hasonló helyzet figyelhető meg a sportélvezet esetében is: a szülöi elvárások és kritika negatív kapcsolatban áll vele, míg a másik két dimenzióval nem igazolható a kapcsolat. A szülői és a saját elvárások növekedésével a sportsérülések is gyakoribbá válnak, ami a teljesítmény emelésével járó nagyobb kockázatra utalhat. Érdemes azt is kiemelni, hogy a sportoló fiúk perfekcionizmus-szintje a legtöbb dimenzióban magasabb, és a pontszámok a sportolási szinttel is emelkednek.

Mindez azt jelentheti, hogy a perfekcionizmus bizonyos formái pozitív, míg mások negatív hatással lehetnek a sportolók tevékenységére. Ezért a perfekcionizmus dimenziói közötti kapcsolatokra építve klaszteranalízist végeztem, amelynek alapján három sportolói csoport különült el: a negatív perfekcionisták (őket az aggodalmak, kételyek és szülői elvárások jellemzik leginkább), a pozitív perfekcionisták (rájuk az összeszedettség és a személyes elvárások, a fejlődés igénye jellemző), valamint a nem-perfekcionisták. Ez a csoportosítás jól tükrözi az ún. háromoldalú modellt (Gotwals, 2016), amely megkülönböztette az egészséges perfekcionistákat, az egészségtelen perfekcionistákat és nem-perfekcionistákat. Ez a beosztás is azon alapul, hogy perfekcionista hozzáállásban a tökéletességre törekvés vagy a tökéletesség 
miatti aggódás dominál. Az elöbbi fejlődésre sarkallhat, az utóbbi viszont szorongáshoz, stresszhez, és akár teljesítményromláshoz is vezethet.

A klaszterekbe történő besorolást befolyásolja a nem: míg a fiúk között lényegesen több negatív, a lányok között több pozitív perfekcionistát találtunk. Ez származhat a fiúkra nehezedő nagyobb teljesítménykényszerből vagy akár a nagyobb szülői és edzői elvárásokból és kritikából. Az eltérő nemi szocializációs hatások (McCreary és mtsai, 2005) mellett biológiai, hormonális okai is lehetnek a különbségnek, hiszen a tesztoszteron magasabb szintje hajlamosít versengésre (Carré és McCormick, 2008). A magasabb szinten versenyzők megoszlanak e tekintetben: nagyjából ugyanannyian tartoznak a negatív, mint a pozitív perfekcionisták közé. A csak helyi vagy hobbi szinten versenyzők közül viszont lényegesen többen tartoztak a nemperfekcionistákhoz. Rájuk kevésbé hat a teljesítménykényszer, ezért a perfekcionista attitüd is kisebb mértékben fordul elő. Egyértelmű azonban az összefüggés a sportsérülésekkel: azok, akik sportsérülésekről számoltak be, döntően a negatív perfekcionisták közül kerültek ki. Madigan és munkatársai (2018) igazolták azt a hipotézist, hogy a perfekcionizmus okozta nagyobb stressz megnövelheti a sportbalesetek kockázatát, méghozzá specifikusan a negatív (egészségtelen) perfekcionizmus, amelyben az aggodalom, a kételyek dominálnak.

A klaszterek szerint elemezve a sport iránti elköteleződési típusokat és forrásokat, megállapítható, hogy míg a pozitív perfekcionistákra a lelkes elkötelezödés, a sportélvezet, az érzelmi közösségi támogatás és a törekvés a fejlödésre a legjellemzőbb, addig a negatív perfekcionistákra az erőltetett elköteleződés mellett az egyéb prioritások, a közösségi nyomás és a személyes befektetés - veszteség. A nem-perfekcionisták viszont alacsony szintü elköteleződést mutattak a legtöbb esetben. Láthatjuk, hogy a perfekcionizmus alacsony szintje sem kedvezö, hiszen nem sarkall a teljesítmény növelésére, a fejlődésre, és elköteleződésük is viszonylag alacsony szintü. Bár az eröltetett elkötelezödés valamivel gyakoribb náluk, mint a pozitív perfekcionisták esetében, a lelkes elköteleződés viszont a legalacsonyabb pontszámot kapta.

A vizsgálatban megvizsgáltam a perfekcionizmus és a sport iránti elköteleződést több szempontból. A különböző elemzések azt mutatták, hogy hipotézisem miszerint az összeszedettség és a személyes elvárások pozitív kapcsolatban állnak a lelkes elkötelezödéssel, igaznak bizonyult, mivel a korrelációs elemzés mellet a klaszterelemzás által kialakított csoportokban is ezek a változók kerültek előterébe a pozitív perfekcionisták csoportjába. A feltételezésemmel összehangban a szülői elvárások, szülői kritika, viselkedés miatti kételyek és 
a hibák miatti aggodalom az erőltetett elkötelezödéssel állnak kapcsolatban (H10), hiszen úgy tünik, hogy a tökéletességre való törekvésben ezek a változók komoly kényszert jelenthetnek a sportolóknak.

\subsection{A sportélvezet vizsgálata}

A disszertációm egészében a sportélvezet központi szerepet töltött be, hiszen a sport iránti elköteleződés egyik legfontosabb tényezőjéről beszélünk. Azt a tényt már többféleképpen megvizsgáltuk és a szakirodalommal egyetemben igazat adhatunk annak a tézisnek, hogy a sportélvezet - ahogy más modellek hívják, a belső motiváció - az egyik legfontosabb része a magas motivációnak és elköteleződésnek. Ennek tudatában egy érdekes kérdés, hogy a serdülők miért is szeretik a sportágukat, vajon milyen tényezőkből származhat az a bizonyos sportélvezet. A fejezetben disszertációm utolsó kérdéskörét és hipotéziseimet $\left(\mathrm{H}_{11}-\mathrm{H}_{12}\right)$ igyekszem megválaszolni.

\subsubsection{A sportélvezet jelentősége és pszichológiai hátterének vizsgálata serdülö sportolók körében}

Az elemzés az első vizsgálatból származó adatokból valósult meg $(\mathrm{n}=526)$. A vizsgálatában felhasználásra kerültek a sportélvezet skála, sport-elköteleződés kérdőív-2 sportélvezet

alskálája, az Élettel való elégedettség és a jövőorientáció skála és az ún. Aspirációs Index.

\subsubsection{Statisztikai módszer}

A vizsgálat első részében „stepwise” regresszió elemzéssel megvizsgáltam, hogy a sportelköteleződés sportélvezet alskálája hogyan magyarázható a Wiersma (2001) féle modellel, melyhez az általa kidolgozott sportélvezet skála faktorait használtam fel. Ezután a változók közötti kapcsolatok erősségének mérésére Pearson korrelációs együtthatókat számoltam és megvizsgáltam különböző pszichológiai háttértényezők közötti kapcsolatok erősségét a sportélvezet faktoraival.

\subsubsection{Eredmények}

A vizsgálatom első részében arra voltam kíváncsi, hogy a Scanlan és munkatársai (2016) által megalkotott sportélvezet, hogyan magyarázatható a Wiersma (2001) féle modellel, hiszen az 
segítheti a sportélvezet mélyebb megértését. A „stepwise” regressziós módszerrel elvégzet elemzés megmutatta, hogy a felhasznált 6 változó a variancia 28 százalékában szignifikáns magyarázó erővel rendelkezik (25. táblázat). A végső modell megmutatta, hogy az erőfeszités jutalma $(\beta=0,38)$ és a saját kompetencia $(\beta=0,27)$ a legerősebb magyarázók, de a csapatszellem $(\beta=0,22)$, szülöi támogatás $(\beta=0,12)$ és a versenyzés izgalma $(\beta=0,10)$ is szignifikáns változói a sportélvezetnek. Ugyanakkor a másokhoz viszonyított kompetencia nem tartozik a szignifikáns magyarázók közé.

25. táblázat. A sportélvezet magyarázó változói Wiersma modellje alapján

\begin{tabular}{|c|c|c|c|c|c|c|}
\hline & & $\mathrm{F}$ & $\mathrm{R}_{2}$ & $\beta$ & SÉ $\beta$ & $\mathrm{t}$ \\
\hline \multirow[t]{20}{*}{ Sportélvezet } & Step 1 & 87,92 & 0,14 & & & \\
\hline & Erőfeszítés jutalma & & & 0,24 & 0,39 & $9,37 * * *$ \\
\hline & Step 2 & 70,58 & 0,21 & & & \\
\hline & Erőfeszítés jutalma & & & 0,25 & 0,38 & $10,02 * * *$ \\
\hline & Saját kompetencia & & & 0,17 & 0,26 & $6,76 * * *$ \\
\hline & Step 3 & 61,35 & 0,26 & & & \\
\hline & Erőfeszítés jutalma & & & 0,25 & 0,38 & $10,24 * * *$ \\
\hline & Saját kompetencia & & & 0,18 & 0,27 & $7,20 * * *$ \\
\hline & Csapatszellem & & & 0,14 & 0,22 & $7,82 * * *$ \\
\hline & Step 4 & 49,53 & 0,27 & & & \\
\hline & Erőfeszítés jutalma & & & 0,25 & 0,38 & $10,30_{* * *}$ \\
\hline & Saját kompetencia & & & 0,18 & 0,27 & $7,25 * * *$ \\
\hline & Csapatszellem & & & 0,14 & 0,22 & $5,96 * * *$ \\
\hline & Szülői támogatás & & & 0,08 & 0,12 & $3,36 * * *$ \\
\hline & Step 5 & 41,79 & 0,29 & & & \\
\hline & Erőfeszítés jutalma & & & 0,25 & 0,38 & $10,45_{* * *}$ \\
\hline & Saját kompetencia & & & 0,18 & 0,27 & $7,28 * * *$ \\
\hline & Csapatszellem & & & 0,14 & 0,22 & $5,92 * * *$ \\
\hline & Szülői támogatás & & & 0,08 & 0,12 & $3,36 * * *$ \\
\hline & Versenyzés izgalma & & & 0,07 & 0,10 & $2,84 * * *$ \\
\hline
\end{tabular}

$* * * \mathrm{p}<0,001$

Kutatásom következő részében kíváncsi voltam, hogy a pszichológiai skálák milyen összefüggéseket mutatnak a sportélvezet feltételezett forrásaival. A korrelációs vizsgálat a következő eredményeket hozta (26. táblázat). A jövőorientáltság skála és a versenyzés izgalma, valamint az erőfeszités jutalma között mutatható ki jelentős kapcsolat. Az élettel való elégedettség skála a csapatszellem és a másokhoz viszonyított kompetencia faktorváltozókkal 
korrelált jelentősen. Az intrinzik aspirációk a saját kompetenciával, míg az extrinzik aspirációk változó a másokhoz viszonyított kompetenciával mutatott összefüggést. A nem tekintetében kapcsolat igazolható a szülöi támogatással (a lányokra vonatkozóan) és a másokhoz viszonyított kompetenciával (a fiúkra vonatkozóan).

26. táblázat. A sportélvezet faktorváltozói és a pszichológiai skálák, valamint a nem közötti kapcsolatos korrelációelemzése

\begin{tabular}{lcccccc}
\hline & $\begin{array}{c}\text { Versen } \\
\text { yzés } \\
\text { izgalm } \\
\text { a }\end{array}$ & $\begin{array}{c}\text { Eröfeszít } \\
\text { és } \\
\text { jutalma }\end{array}$ & $\begin{array}{c}\text { Csapatszelle } \\
\mathrm{m}\end{array}$ & $\begin{array}{c}\text { Saját } \\
\text { kompetenc } \\
\text { ia }\end{array}$ & $\begin{array}{c}\text { Szülői } \\
\text { támogat } \\
\text { ás }\end{array}$ & $\begin{array}{c}\text { Másokhoz } \\
\text { viszonyítot } \\
\text { t } \\
\text { kompetenc } \\
\text { ia }\end{array}$ \\
\hline $\begin{array}{l}\text { Nem (fiú }=1, \\
\text { lány =2) }\end{array}$ & $-0,17$ & $-0,09$ & $-0,01$ & 0,07 & $0,24 *$ & $-0,24 *$ \\
$\begin{array}{l}\text { Jövőorientáltság } \\
\text { skála }\end{array}$ & $0,28 * *$ & $0,37 * * *$ & 0,10 & 0,13 & 0,16 & 0,09 \\
$\begin{array}{l}\text { Élettel való } \\
\text { elégedettség } \\
\text { skála }\end{array}$ & 0,12 & 0,17 & $0,27 * *$ & 0,18 & 0,15 & $0,22^{*}$ \\
$\begin{array}{l}\text { Intrinzik } \\
\text { aspirációk }\end{array}$ & $-0,02$ & 0,16 & 0,15 & $0,26 * *$ & $-0,02$ & 0,15 \\
$\begin{array}{l}\text { Extrinzik } \\
\text { aspirációk }\end{array}$ & 0,07 & 0,08 & $-0,02$ & 0,08 & 0,02 & $0,36^{* * *}$ \\
\hline *p<0,05; **p<0,01; $* * * \mathrm{p}<0,001$ & & & & & & \\
\hline
\end{tabular}

Vizsgálatunk utolsó részében a Wiersma (2001) javaslatára a sportélvezet összevont kategóriái és a pszichológiai skálák között kerestem korrelációs kapcsolatot (27. táblázat). Az extrinzik sportélvezet a jövöorientáltság, az élettel való elégedettség skálákkal, valamint az extrinzik aspirációk változójával korrelált. Az intrinzik sportélvezet szintén a jövőorientáltság és az élettel való elégedettség skálákkal, illetve az extrinzik aspirációval mutatott kapcsolatot. A teljesítménnyel összefüggő sportélvezet az élettel való elégedettség skálával, valamint az intrinzik és extrinzik aspirációkkal volt szignifikánsan összefüggésben. Ki kell azonban emelni, hogy az utóbbi korreláció értéke volt a legmagasabb. Végül a teljesítménytől független sportélvezet a jövöorientáltsággal és az élettel való elégedettséggel mutatott összefüggést, míg az aspirációkkal egyáltalán nem. 
27 táblázat. A sportélvezet kategóriái és a pszichológiai skálák, valamint a nem közötti

kapcsolatos korrelációelemzése

\begin{tabular}{lllll}
\hline & $\begin{array}{l}\text { Extrinzik } \\
\text { sportélvezet }\end{array}$ & $\begin{array}{l}\text { Intrinzik } \\
\text { sportélvezet }\end{array}$ & $\begin{array}{l}\text { Teljesítménnyel } \\
\text { összefüggö } \\
\text { sportélvezet }\end{array}$ & $\begin{array}{l}\text { Teljesítménytöl } \\
\text { független } \\
\text { sportélvezet }\end{array}$ \\
\hline $\begin{array}{l}\text { Nem (fiú =1, lány =2) } \\
\text { Jövőorientáltság skála }\end{array}$ & $-0,01$ & $-0,11$ & $-0,12$ & $-0,01$ \\
$\begin{array}{l}\text { Élettel való elégedettség } \\
\text { skála }\end{array}$ & $0,20^{*}$ & $0,47^{* * * *}$ & 0,16 & $0,45^{* * *}$ \\
Intrinzik aspirációk & 0,16 & $0,27 * *$ & $0,27^{* *}$ & $0,35^{* * *}$ \\
Extrinzik aspirációk & $0,21^{*}$ & $0,23 *$ & $0,29 * *$ & 0,14 \\
\hline
\end{tabular}

$* \mathrm{p}<0,05 ; * * \mathrm{p}<0,01 ; * * * \mathrm{p}<0,001$

\subsubsection{Megbeszélés}

A fejezetbe igyekeztem, egy olyan kérdést megközelíteni, mely sok kutatót foglalkoztat és a disszertációban is központi helyet kapott, vagyis, hogy miért is szeretünk sportolni. Úgy döntöttem, hogy az elemzéshez, hogy Scanlan (2016) megközelítését és Wiersma sportélvezet modelljét használom. Scanlan sportélvezet megközelítése igen általános, ám kutatások bizonyítják, hogy megbízhatóan vizsgálja a sportélvezetet. Wiersma modellje pedig mélyebb megértést nyújthat, ám túlságosan is a sportélvezet alsóbb szintjeire koncentrál. Ezért döntöttem, a két megközelítés felhasználása mellet. Így regressziós elemzéssel megvizsgáltam a kapcsolatait. Ahogy hipotéziseimben (H11) feltételeztem a sportélvezethez legfontosabb a saját kompetencia, azaz, hogy a sportoló ismerjen és tudjon egy adott mozgásformát. Ám meglepő módon elemzésemből mégsem ez a változó állt az első helyen. Az eröfeszités jutalma a teljesítményt írja le, mely a regressziós modellben az első helyet foglalta el. Számos kutatás megmutatta, hogy a teljesíthető célok, a nagyobb teljesítményre ösztönzés motiválható lehet a serdülők számára (Gunnel és mtsai, 2014). Ennek alapján a sportélvezet előbb említett két faktora talán a kulcsa lehet annak, hogy minél több serdülö szeresse meg a sport a mozgást, hiszen a legtöbb serdülő - de akár felnőtt is - olyan dolgokat szeret, melyeket tud és képes teljesíteni. A teljesítményhez kapcsolódik a versenyzés izgalma változó is, amely a leggyengébb szignifikáns magyarázónak bizonyult. Fontosnak érzem még megemlíteni, hogy a három faktor intrinzik jellegú, mely egybevág több a belső motivációhoz kapcsolódó elmélettel is (pl.: Deci és Ryan, 2000). 
A mintában a csapatszellem és a szülői támogatás is megjelenik a sport élvezetében. A társak és a szülők sok motivációs megközelítés központjában állnak (Atkins és mtsai, 2015), így nem meglepö, hogy itt is megjelennek, mint pozitív faktor. A társak komoly élvezeti forrással bírhatnak, hiszen sok olyan serdülő van, aki csak a barátai miatt jár le minden nap edzésre. A szülő támogató környezete is úgy tủnik elengedhetetlen. A szülők képesek átadni a sport szeretetét, mely nagyban hozzájárulhat a hosszútávú sportolás megvalósításához. A két extrinzik elem - mely nagyban hasonlít a közösségi támogatás elemekhez - szerepe a motivációban vitatott, de úgy vélem, hogy a sport szeretetének kialakításában nagyban szerepe van, hiszen a vizsgálatban tapasztaltak mellett a sport-elköteleződés vizsgálat is hasonló eredményt mutatatott (sportélvezet pozitívan korrelált a kétféle közösségi támogatás típussal).

A sportélvezet források és a pszichológiai skálák összefüggését szakirodalmi kutatásunk szerint még nem vizsgálták, ezért hipotéziseimet korábbi, hasonló kutatások (Chatzisarantis és Hagger, 2007; Stuntz és Weiss, 2009) alapján állítottam fel. A hipotézisem annyiban teljesült, hogy igazolhatók a kapcsolatok a pszichikai jóllét-mutatók, valamint a sportélvezet-faktorok között, azonban az utóbbiak nem igazán, vagy nem a várt módon térnek el a pszichikai változók mentén (H12). Igaz a jövőorientáltság leginkább azokkal az intrinzik (versenyzés izgalma, erőfeszítés jutalma) forrásokkal korrelál, amelyek befolyásolhatják a teljesítményt, amely egybevág a feltételezéseimmel.

Az élettel való elégedettség skála azonban olyan extrinzik elemekkel van kapcsolatban, mint a másokhoz viszonyított kompetencia és a csapatszellem. Ez az eredmény talán arra enged következtetni, hogy akiknek nem az eredmény számít, azoknak fontosabbak a barátok és a társaság, így elégedettebbek is az életükkel. Ha az aspirációs skáláról kapott eredményeket megnézzük, az intrinzik aspirációk a szintén intrinzik saját kompetenciával korrelálnak, míg az extrinzik aspirációk a másokhoz viszonyított kompetenciával mutatnak kapcsolatot, ami szintén egy extrinzik elem. A nemek tekintetében is összefüggések figyelhetők meg. Jól látszik, hogy a sportélvezetben nagyobb szerepe van a szülöi támogatásnak a lányok esetében, míg fiúknál a másokhoz viszonyított kompetencia mutat korrelációt, ami talán annak köszönhető, hogy a fiúk versengőbbek, mint a lányok.

Az összevont kategóriákat tekintve elsőként kiemelendő, hogy az extrinzik és intrzinik aspirációk esetében előbbi az extrinzik utóbbi pedig az intrinzik sportélvetettel mutatott kapcsolatot. Továbbá mind az extrinzik, mind pedig az intrinzik sportélvezet összefügg a 
jövőorientáltsággal és az élettel való elégedettséggel; míg az extrinzik föként az utóbbival, az intrinzik az elöbbivel. A teljesitménnyel összefüggő és teljesitménytöl független kategóriákban viszont sajátos összefüggés rajzolódik ki. Az előző eredményekből azt gondolhatnánk, hogy a teljesítménnyel összefüggő sportélvezet összefügg a jövőorientáltsággal, ez azonban nincs így. Ellenben a teljesitménytöl függö sportélvezet az intrinzik és extrinzik aspirációkkal egyaránt korrelált, sőt utóbbinál találtuk a legmagasabb értéket az egész mintában. Ami nem véletlen, hiszen a teljesítmény nemcsak belső, hanem külső motivációkon, pl. elismerésen vagy jutalmon is alapul, föként a rendszeres versenyzőknél. Mivel az aspirációk is a jövőbeli életcélokkal függenek össze, úgy tủnik, hogy általában nem a jövőorientáltsággal állnak összefüggésben, hanem konkrét célok megvalósításával. Ez szintén az eredményhez kötöttségre, teljesítménycentrikusságra utal. A teljesítménytöl független sportélvezet viszont nem függ össze egyik aspirációval sem, csupán a jövőorientáltsággal és az élettel való elégedettséggel.

Összefoglalásként elmondhatom, hogy a sportélvezet legfontosabb forrása mintámban a sportoló kemény munkával megszerzett képességéből ered (eröfeszités jutalma), melyet a serdülök sportági tudása követ (saját kompetencia). Ez az eredmény nem állt összhangban előzetes feltételezésemmel (H11), hiszen a saját kompetencia, csupán a második legfontosabb forrásnak bizonyult. Nehéz azonban következtetést levonni az éltettel való elégedettség, aspirációk, jövőorientáció és a sportélvezet modell kapcsolatáról. Eredményeim csupán részben igazolták feltételezéseimet (H12), hiszen az élettel való elégedettség és a jövőorientáció nem csak az intrinzik hanem extrinzik sportélvezet forrásokkal is kapcsolatban álltak. Ugyanakkor az aspirációs skálák a feltételezéseimnek megfelelően az extrinzik és intrinzik sportélvezet változókkal álltak kapcsolatban. 


\section{KÖVETKEZTETÉSEK \\ 6.1. Hipotézisek ellenőrzése}

Kutatásaim végén az eredményeimet az előzetesen felállított hipotéziseim mentén is szeretném kontextusba helyezni, melyeket igyekeztem táblázatos formában is összefoglalni (28. táblázat). A táblázat összefoglalóan bemutatja mind a 12 hipotézisem, és megválaszolja a kérdést, hogy az megvalósult, nem valósult meg, vagy csak részben valósult-e meg.

\section{8. táblázat. Az empirikus kutatás hipotéziseinek összefoglalása.}

\begin{tabular}{|c|c|}
\hline Hipotézisek & \\
\hline $\begin{array}{l}\text { H1: Feltételezem, hogy a magyarra fordított és adaptált skálák (sport-elköteleződés kérdőív-2, } \\
\text { sportélvezet, sportolói identitás) megfelelő megbízhatósággal és faktorszerkezettel } \\
\text { rendelkeznek. }\end{array}$ & I \\
\hline $\begin{array}{l}\text { H2: Feltételezem, hogy a kor, nem, anyagi helyzet, sportág, sportolás szintje, sportolási ideje, } \\
\text { edzésmennyisége, egyéni/csapatsport jellege befolyásolják a sport-elköteleződés modell } \\
\text { változóit. }\end{array}$ & I \\
\hline $\begin{array}{l}\text { H3: Feltételezem, hogy a lelkes elköteleződés magas, míg az erőltetett elköteleződés alacsony } \\
\text { öndeterminációval áll kapcsolatban. }\end{array}$ & I \\
\hline $\begin{array}{l}\text { H4: Feltételezem, hogy az alacsonyabb öndetermináció inkább a közöségi jellegü, befektetések, } \\
\text { valamint az alternatívákat leíró változókkal állhatnak kapcsolatban (pl.: közösségi kényszer), } \\
\text { míg a magasabb öndeterminációra az egyéni jellegü és teljesítményt leíró (pl.: sportélvezet, } \\
\text { törekvés a fejlődés - képesség) változók jellemzőek. }\end{array}$ & $\mathrm{R}$ \\
\hline $\begin{array}{l}\text { H5: Feltételezem, hogy a sport iránti elköteleződés közösségi szintủ változói, valamint a lelkes } \\
\text { elköteleződés, a sportélvezet, a sportban rejlö lehetőségek, befektetések, az egyéni törekvések a } \\
\text { fejlödésre, pozitív hatással lehetnek a sportolói identitásra. }\end{array}$ & $\mathrm{R}$ \\
\hline H6: Feltételezem, hogy az erőltetett elköteleződés negatívan befolyásolja a sportolói identitást & $\mathrm{H}$ \\
\hline $\begin{array}{l}\text { H7: Feltételezem, hogy a sportélvezet, értékes lehetőségek, és a törekvés a fejlődésre - képesség, } \\
\text { személyes befektetések - mennyiség változóknak pozitív, kapcsolata van a lelkes } \\
\text { elköteleződéssel. }\end{array}$ & I \\
\hline $\begin{array}{l}\text { H8: Feltételezem, hogy az egyéb prioritások, személyes befektetések - veszteség és a közösségi } \\
\text { kényszer változóknak pozitív kapcsolata van az erőltetett elköteleződéssel. }\end{array}$ & I \\
\hline $\begin{array}{l}\text { H9: Feltételezem, hogy a magasabb szubjektív jóllét, intrinzik aspiráció, jövőorientáció és az } \\
\text { egészségattitűd skálák értékei a lelkes elköteleződéssel állnak kapcsolatban, míg az alacsonyabb } \\
\text { értékei, és az extrinzik aspiráció az erőltetett elköteleződésre hatnak. }\end{array}$ & $\mathrm{R}$ \\
\hline $\begin{array}{l}\text { H10: Feltételezem, hogy a perfekcionizmus alskálái közül az összeszedettség és a személyes } \\
\text { elvárások a lelkes elköteleződéssel, míg a szülői elvárások, szülői kritika, viselkedés miatti } \\
\text { kételyek és a hibák miatti aggodalom az eröltetett elköteleződéssel állnak kapcsolatban. }\end{array}$ & I \\
\hline H11: Feltételezem, hogy a kompetencia a sportélvezet legfőbb forrása & $\mathrm{H}$ \\
\hline $\begin{array}{l}\text { H12: Feltételezem, hogy a sportélvezet modell intrinzik jellegü forrásai az élettel való } \\
\text { elégedettséggel, a jövőorientációval és az intrinzik aspirációkkal mutatnak kapcsolatot, míg az } \\
\text { extrinzik jellegű források az extrinzik aspirációkkal állnak kapcsolatban. }\end{array}$ & $\mathrm{R}$ \\
\hline
\end{tabular}

$\mathrm{I}=$ igaz; $\mathrm{H}=$ hamis; $\mathrm{R}=$ részben igaz

A felállított hipotéziseim fele beigazolódott és mindössze két olyan feltételezésem volt, amely nem bizonyult helyesnek. Négy hipotézisem pedig csak részben fogadható el, ami további 
kutatásokra sarkallhat. A következőkben hipotéziseimre adott megállapításaimat foglalom össze:

H1: Feltételezem, hogy a magyarra fordított és adaptált skálák (sport-elkötelezödés kérdöív-2, sportélvezet, sportolói identitás) megfelelö megbizhatósággal és faktorszerkezettel rendelkeznek.

A három adaptált skála statisztikai elemzése megmutatta, hogy a kérdőívek jól használhatóak magyar mintán, így hipotézisem igazolást nyert. Azt fontos megjegyezni, hogy a skálák a faktorokban ugyan megegyeztek, de item számukban (sport-elköteleződés kérdőív-2, sportélvezet) eltérést mutattak az eredeti verziókkal. Ezzel együtt a skálák tökéletesen alkalmazhatóak a magyar mintán, melyet az elemzések mellett a megbízhatósági mutatók is igazoltak.

H2: Feltételezem, hogy a kor, nem, anyagi helyzet, sportág, sportolás szintje, sportolási ideje, edzésmennyisége, egyéni/csapatsport jellege befolyásolják a sport-elkötelezödés modell változóit.

Az eredményeim teljes mértékben igazolták az előzetes várakozásaimat, hiszen mint láthattunk a sport-elköteleződés eltér nemenként, sportáganként, változik a korral és befolyással van rá a sportolás szintje is. A feltevések iránya sok esetben megegyezett a motivációs szakirodalomban tapasztaltakkal is (pl.: nem és a kor összefüggései; Szemes és mtsai, 2016).

H3: Feltételezem, hogy a lelkes elkötelezödés magas, míg az eröltetett elkötelezödés alacsony öndeterminációval áll kapcsolatban.

Az öndetermináció és a sport-elköteleződés kapcsolata fontos része volt a kutatásomnak. Az egyértelmü ugyan, hogy az elköteleződés komplex fogalom, de eredményeimből látszik, hogy a kétféle sport-elköteleződés típus jól elkülönült az öndeterminációs kontinuumon. A lelkes elköteleződés a magas öndeterminációval (belső motiváció), míg az erőltetett elköteleződés az alacsony öndeterminációval mutatott kapcsolatot (amotiváció, külső szabályozás), így a hipotézis igaznak bizonyult. 
H4: Feltételezem, hogy az alacsonyabb öndetermináció inkább a közöségi jellegü, befektetések, valamint az alternatívákat leíró változókkal állhatnak kapcsolatban (pl.: közösségi kényszer), míg a magasabb öndeterminációra az egyéni jellegü és teljesítményt leíró (pl.: sportélvezet, törekvés a fejlödés - képesség) változók jellemzőek.

A hatodik hipotézisemet nem sikerült egyértelmüen bizonyítani. Vannak olyan sportelköteleződés források, melyek egyértelmüen meghatározhatóak az öndetermináció részeivel, de sok esetben a források végig kísérik az öndetermináció folytonosságát, így az látszik, hogy a sport-elköteleződés forrásainak komplex jelentése miatt nem lehet egyértelműen kijelenteni, hogy intrinzik vagy extrinzik elem lenne.

H5: Feltételezem, hogy a sport iránti elkötelezödés közösségi szintü változói, valamint a lelkes elkötelezödés, a sportélvezet, a sportban rejlö lehetöségek, befektetések, az egyéni törekvések a fejlödésre, pozitív hatással lehetnek a sportolói identitásra.

A sportolói identitással kapcsolatos eredményeim is csupán részben igazolódtak. A sportélvezet és törekvés a fejlödésre - képesség faktorok (mely nagymértékben kapcsolódnak a belső motivációhoz) negatív kapcsolatban álltak az identitással, ugyanakkor előzetes feltételezésemmel megegyezően a lelkes elköteleződés, az értékes lehetőségek és a személyes befektetések - mennyiség mind pozitív kapcsolatban álltak a sportolói identitással. Úgy tünik, egy olyan sportoló is rendelkezhet magas sportolói identitással, aki kevésbé szereti a sportágát.

H6: Feltételezem, hogy az eröltetett elkötelezödést negatívan befolyásolja a sportolói identitást.

Tévesnek bizonyult az a feltevésem miszerint az identitás negatív kapcsolatban áll az identitással. A vizsgálatomból az látszik, hogy a kényszer is okozhat magasabb sportolói identitást. Ez az eredmény megerősíti az előző hipotézisem eredményeit is, hiszen a sportolói identitás különböző mértékben befolyásolhatja a sport-elköteleződés modellt.

H7: Feltételezem, hogy a sportélvezet, értékes lehetőségek, és a törekvés a fejlödésre - képesség, személyes befektetések - mennyiség változóknak pozitív, kapcsolata van a lelkes elkötelezödéssel.

A lelkes elkötelezödéssel kapcsolatos feltételezéseim igaznak bizonyultak. A sportélvezet, értékes lehetöségek, és a törekvés a fejlödésre - képesség, valamint a személyes 
befektetések - mennyiség változók határozottan pozitív hatással vannak a lelkes elköteleződésre, melyet a szakirodalom is megerösít (Scanlan és mtsai, 2016). Így elmondható, hogy a lelkesen elkötelezett sportolók a sport szeretete miatt sportolnak, amiben lehetőséget és célokat látnak, és így hajlandóak is időt, energiát belefektetni.

H8: Feltételezem, hogy az egyéb prioritások, személyes befektetések - veszteség és a közösségi kényszer változóknak pozitív, kapcsolata van az eröltetett elkötelezödéssel.

Nem csak a lelkes elkötelezödéssel kapcsolatos eredményeim mutattak egyértelmü kapcsolatot. Igaznak bizonyult az eröltetett elkötelezödéssel kapcsolatos feltételezésem is, melyet a szakirodalom is határozottan megerősít (Scanlan és mtsai, 2016). Az eredményekből az olvasható ki, hogy az alternatívák, társadalmi nyomás és a félelem az addig befektetett energia elvesztésétől, erősíthetik az erőltetett elköteleződést.

H9: Feltételezem, hogy a magasabb szubjektív jólét, intrinzik aspiráció, jövőorientáció és az egészségattitüd skálák értékei a lelkes elkötelezödéssel állnak kapcsolatban, míg az alacsonyabb értékei, és az extrinzik aspiráció az erőltetett elkötelezödésre hatnak.

Az egészségpszichológiai háttér vizsgálata érdekes képet mutatott a sport-elköteleződés modellel kapcsolatban. Ez a csak részben igazolódott. Az egyértelmüen látszik az eredményeimből, hogy a magasabb pszichológiai változók inkább a lelkes elköteleződéssel álltak kapcsolatban, ám az egészségattitüdök skála már nem hozta az előzetes elvárásaimat. Úgy tünik az egészséges életmódra való törekvés a mintámban inkább a kényszerből történő sportolást erösíti.

H10: Feltételezem, hogy a perfekcionizmus alskálái közül az összeszedettség és a személyes elvárások a lelkes elkötelezödéssel, míg a szülöi elvárások, szülöi kritika, viselkedés miatti kételyek és a hibák miatti aggodalom az eröltetett elkötelezödéssel állnak kapcsolatban.

$\mathrm{Az}$ eredményeim teljes mértékben igazolták az előzetes várakozásaimat. A perfekcionizmusra egyfajta kettősség jellemző, mely az elemzésemből is meglátszott. Eredményeimből arra lehet következtetni, hogy a tökéletességre törekvés valamennyi változója segítheti a sportolókat céljaik elérésében. 
H11: Feltételezem, hogy a kompetencia a sportélvezet legföbb forrása

Elemzésem meglepő eredményt hozott, mely nem igazolta az elöre felállított hipotézisemet. Mint kiderült, a mintámban az erőfeszités jutalma a sportélvezet legfőbb forrása, amely a sportolók kemény munkával megszerzett képességéből ered.

H12: Feltételezem, hogy a sportélvezet modell intrinzik jellegü forrásai az élettel való elégedettséggel, a jövőorientációval és az intrinzik aspirációkkal mutatnak kapcsolatot, míg az extrinzik jellegü források az extrinzik aspirációkkal állnak kapcsolatban.

Feltételezésem részben igazolódott. Az élettel való elégedettség és a jövőorientáció nem csak az intrinzik hanem extrinzik sportélvezet forrásokkal is kapcsolatban álltak. Ugyanakkor az aspirációs skálák a feltételezéseimnek megfelelően az extrinzik és intrinzik sportélvezet változókkal álltak kapcsolatban.

\subsection{Az eredmények összefoglalása és értelmezése}

A fizikai aktivitás pozitív szerepét a szakirodalom mellett a mindennapok megfigyelése és a disszertációm eredményei is alátámasztják. Kutatásomban képet kaphattunk a mintám sportelköteleződés profiljáról, mely talán segíthet megérteni milyen tényezőket kellene fejleszteni annak érdekében, hogy minél többen sportoljanak. Egy másik értékes eredménye a vizsgálatomnak, hogy a sport-elköteleződés témában eddig nem született magyar nyelvü tanulmány, amely érdekes eleme lehet a motivációs kutatásoknak is.

Kutatásaim egyik sarkalatos pontja volt, hogy még nem létezett olyan hazai tudományos munka, mely írna a sport-elköteleződés, sportélvezet és sportolói identitás modelljeiről. Így nem csak az elméletekkel kapcsolatos magyar terminológiát kellett megteremteni, de a hozzájuk tartozó mérőeszközök adaptálása is a kutatás feladata volt. Összesen 3 olyan kérdöív került lefordításra és adaptálásra, melyek megbízhatónak bizonyultak a kutatás folyamán és bízom benne, hogy a jövőben értékes támaszt nyújthatnak hasonló kutatásokhoz.

A tanulmányomban az empirikus kutatás számos összefüggést mutatott. Kimutattam összefüggéseket a szociodemográfiai adatokkal, sportolási szokásokkal, más motivációs elméletekkel és az egészségpszichológiával is. Ezek alapján a sport-elköteleződési modell profilja azt mutatta, hogy a mintában szereplő serdülő sportolóknak lelkes elkötelezödésre a sportélvezet, értékes lehetöségek, törekvés a fejlesztésére - képesség, valamint a személyes - 
befektetések - mennyiség elemek a jellemzők. Az erőltetett elkötelezödésre pedig az egyéb prioritások, személyes befektetés - veszteség, közösségi támogatás - informális, közösségi kényszer, a jellemzőek. Azaz ezek a sportolók, ha lelkesen köteleződnek el, akkor azért sportolnak, mert szeretik, és olyan lehetőségeket kapnak tőle, amelyek arra sarkalják őket, hogy még többet fektessenek a sportágukba, mely a céljaik között is szerepel. Ők többet és magasabb szinten is sportolnak és érdekes módon azokban a csapatsportágakban magasabb a lelkes elkötelezödés aránya, ahol a sport egyfajta alternatívaként szolgál a későbbi karrier szempontjából (pl.: labdarúgás - ahol az akadémiákon lévő fiatalok komplex nevelésben részesülhetnek). Ezzel szemben az erőltetett elköteleződésnek a sportra pozitív, de a serdülök motivációs attitüdjére már negatív hatással van, hiszen számukra az alternatívák komoly szerepet játszanak, és inkább azért maradnak a sportban, hogy valakiknek megfeleljenek, valamint a már addig befektetett energiát sem hagynák kárba veszni. Az eröltetetten elköteleződött fiatalok nem is sportolnak magas szinten és nem is vesznek részt sok edzésen. Érdekes módon a sportolási kényszer veszélye valamennyi sportágat érinti, hiszen nem mutatott szignifikáns különbséget a mintában az erőltetett elköteleződés és a sportági összehasonlítás.

Ezekkel összhangban a következtetéseimet arra szeretném kihegyezni, hogy milyen gyakorlati lehetőségeket látok a sport iránti elköteleződés növelése terén, melyek fejlesztésével nemcsak az élsportolóknál, hanem az amatőr és a szabadidő sportolóknál is lehetne változásokat elérni és növelni a rendszeres testmozgás üzők számát és csökkenteni a lemorzsolódást. Megvizsgálva azokat a változókat, amelyek eredményeimben nagyban befolyásolják az elköteleződést láthatjuk, hogy számtalan fejlesztési lehetőség van elöttünk. Ugyanakkor úgy látom, hogy elsősorban az iskolai testnevelés az (hiszen ott sportolnak a legtöbben), ahol sokat lehetne tenni a serdülők sport iránti elköteleződésének növelésénél.

Véleményem szerint ehhez a sportélvezet kialakításán át vezet az út. A sportélvezet nagyon fontos bármilyen szinten is, ám ennek megteremtése nem magától érthető dolog. A serdülök, de még az idősebbek is azt szeretik csinálni, amit tudnak (így van ez más tevékenység esetén is, hiszen például a kémiát is azok a tanulók szeretik akik értik a reakciókat), így az iskolai testnevelés egyik fontos feladatának a kompetenciák megteremtését gondolom, melybe bele kell hogy férjen a teljesítőképesség megteremtése, a versengésnek és azoknak a mozgáskoordinációs képességeknek a fejlesztése, amelyek elengedhetetlenek a mindennapos életben (pl.: a téribeli tájékozódó képesség megteremtése, mely később a mindennapokban is fontos pl. a gépkocsi 
vezetésben). Ezek kifejlesztése az alapja annak, hogy a serdülő szeresse a mozgást és később akár egy hosszútávú elköteleződés is kialakuljon. Eredményeim is ezt támasztják alá. Hiszen a sportélvezet (más motivációs elméletekben a belső motiváció) vizsgálatomban több helyen is az első pozíciót foglalta el, melyet teljesítőképesség és egyéni kompetenciák is hajtottak. A versengés és a teljesítmény megjelenik a disszertáció több vizsgálatban is (gondoljunk a törekvés a fejlödésre változó szerepére). Ennek fontoságáról beszélni nem újkeletü, holott újra és újra fel kell hívni erre sport szakemberek figyelmét, hogy verseny nélkül nincs sport. Ezt az állítást több magyarországi neves sportpedagógus is kiemeli és ez nemcsak a sport, hanem az egész élet részét is képezi (pl.: Gombócz, 2019). Gondoljunk csak arra, hogy ha két ember elmegy tollaslabdázni és csak ,ütögetni” szeretnének viszonylag gyorsan kialakulhat az a helyzet, hogy a partnerek elkezdik számolni, hogy mennyit tudnak csinálni. Ezzel egy ilyen egyszerü szituációban is máris megjelenik a versengés és a teljesítmény. Egy másik példát hozva, ha megnézzük ma a hazai amatőr futó társadalmat ott is hasonló dolgokkal találkozhatunk. Sokan kezdtek el futni az elmúlt években és ez a hóbort viszonylag gyorsan olyan akarattal társult, hogy az amatőr futók már nem csak lefutni akarnak egy-egy félmaratont, hanem növelni kívánják a távot, gyorsulni akarnak, azaz minél nagyobb teljesítményt szeretnének elérni, amibe pénzt, időt és energiát is hajlandóak befektetni.

Van egy másik szempont is, amely sport sokat adhat egy serdülő sportolónak. Ezek a lehetőségek. Úgy látom, hogy a mai fiatalok értékrendjében ennek kiemelt jelentősége van, hiszen a sport lehetőséget és élményt jelenthet számukra, vagyis körbe utazhatják az országot elmehetnek külföldre vagy az edzőtáborban és kicsit függetlenedhetnek szüleiktől. A vizsgálataim fontos helyre teszik a lehetőségeket, bár nem a legfontosabbnak ítélik azt, amelyek talán szerepet játszhatnak azok a fiatalok motivációjában; vagyis így elmehetnek a világ másik felére vagy bejuthatnak olyan helyekre ahová azelőtt nem tudtak (pl.: gondoljunk abba bele, hogy mennyi utánpótlás korú sportoló volt a 2019 őszén megrendezett magyar válogatott labdaragú mérkőzésen, akik amúgy nem jutottak volna el oda, ha nem sportolnánk). Szerencsére az ilyen és ehhez hasonló lehetőségek száma folyamatosan nő. Egyre jobb és kidogozottabb diákolimpiai rendszer áll a serdülök rendelkezésére és folyamatosan épülnek a sportpályák uszodák, melyek modern külsővel csalogatják a fiatal sportolókat.

Fontos, hogy beszéljünk a kortárs- és szülöi csoportok szerepéröl is a sportban. Több vizsgálatban is előjött a szerepük, ám a következetlen eredményekből nehéz messzemenő 
következtetéseket levonni. Az eredményekből azt gondolom, hogy a támogató környezet és a jó példa elengedhetetlen, ám a következetlen eredmények melyek a szakirodalomban is megjelennek talán annak köszönhetőek, hogy a serdülők környezete változatos, azaz a támogatások mellett az elvárosok is jelen vannak, így kialakítva serdülőkben a társadalmi normákat. Az empirikus vizsgálatomban több helyen is megjelent a közösség általi elvárások vagy támogatások, amik könnyen át tudnak menni kényszeré, hiszen a sportolók sok esetben nagy stressz éri, mely a szülőktől és az edzőktől érkező teljesítménykényszer eredményezhet.

Számos olyan faktorral találkozhatunk a vizsgálataimban, melyek inkább külső segítséggel támogatják a sportolást. Ilyen volt a közösségi kényszer változó és az egészségattitüdök is. A két elem magára a sport részvételre pozitív hatással van, de az elköteleződésre már inkább negatív. Ugyanakkor a tény, hogy azért sportolok, hogy lefogyjak, vagy mert a barátaim vagy a családom elvárja, hosszútávon eredményesebb lehet, hiszen a külső motiváció átalakulhat belső motivációvá is. A motivációs kutatások azt javasolják, hogy mindenképp a belső motiváció felé kell terelni az egyéneket, hiszen a magas belső motiváció védő faktor szerepét is betöltheti a kiégéssel szemben (Barcza-Renner és mtsai, 2016).

Ezek alapján testnevelőként úgy vélem, hogy a serdülők sport iránti elköteleződésének megteremtéséhez elösorban a helyes mozgáskészség kialakításán keresztül vezet az út (melyben szerepet játszik a teljesítmény, versengés és a cél), valamint az olyan lehetőségek megteremtésén, amelyek vonzóak a fiatalok számára. Természetesen ezek megvalósítása nem mindegy hogyan történik, azonban a kutatásomnak nem is volt célja ezt kialakítani. Ezen feladatok megvalósítása a gyakorló edzők, testnevelők feladata kellene, hogy legyen. Ám ha megnézzük az elmúlt évek testnevelés és szabadidős sport kezdeményezéseit, egyre több olyan módszerrel és lehetőséggel találkozhatunk, amelyek az élmény megélését segítik elő a testnevelés órán és azon kívül egyaránt. Az egyik ilyen az ún. KIP (Komplex Instrukciós Program) módszer alkalmazása a testnevelés órán (Fóti, Borosán és Budainé, 2019), mely alternatív pedagógiai módszerekkel segít megvalósítani a diákok számára az élmény szintü tanórákat.

Kutatásomban gyakran előkerült a motiváció fogalma, hiszen mint láthattuk a sportelköteleződés modell más motivációs elméletekkel is kapcsolatot mutat. A lelkes elköteleződés a magasabb öndeterminációval és magasabb sportolói identitással is összefügg. Az erőltetett elköteleződés pedig inkább az amotivációhoz és az alacsonyabb sportolói identitáshoz 
kapcsolható. Ezeknek a vizsgálatoknak a jelentőségét abban látom, hogy bizonyított lett az elköteleződés kapcsolata a motivációval, hiszen egy olyan elméletről van szó, mely új megvilágításba helyezheti a serdülők sportolási attitüdjét.

Disszertációmban kiemelten foglalkoztam az egészségpszichológiával. A kutatásaim megmutatták, hogy a sport-elköteleződés tényezőinek emelésével nem csak a sportolási kedvet növelhetjük, hanem azok hatással lehetnek az egyén, azaz a serdülő egészségpszichológiájára, így a jóllétére vagy céljaira is. A vizsgálataimból kiderült, hogy a szubjektív jóllét, perfekcionizmus, aspirációk és a jövőorientáció nem csak magától a rendszeres fizikai aktivitástól nőhet, hanem az elköteleződés is hatással van rá. Úgy tünik, hogy a magasabb sportelköteleződésű és belsőleg motivált sportolónál találhattunk magasabb értéket ezek a téren. Ez az eredmény még inkább arra sarkalhatja a pszichológusokat, pedagógusokat, sport szakembereket, hogy minél jobban megszerettessék a sportot a serdülőkkel, hiszen így nagyobb hatással lehetnek az egészségpszichológiájukra, mintha valami külső hatással erőltetnék a sportolást.

Kutatásom központi kérdése volt, hogy maga az egészségattitüd hogyan kapcsolódhat a modellhez, vajon megjelenik-e forrásként a modellben. Eredményeim egyértelmüen azt mutatták, hogy az erőltetett elkötelezödéssel van kapcsolatban, ami egy igen érdekes eredmény, hiszen a sport és testmozgás fontossága mindig is az egészség köré épült. Ez természetesen nem jelenti azt, hogy ennek nincs pozitív hatása a sportban való részvételre, de a sportolás növeléséhez nem elég az egészséges életmódra való felhívás, hanem tömegsport rendezvények révén, vagy kihívásokat támasztva a serdülők vagy akár a társadalom egésze elé, kell elérni, hogy mind többen és mind többet mozogjanak a mindennapokban.

\subsection{Korlátok és további kutatási irányok}

Sok olyan fejlesztési lehetőséget írtam le, amelyek általános érvényüek lehetnek, ám fontos megjegyezni, hogy kutatásomnak számos olyan korlátja van, amely miatt nem lehet azt mondani, hogy a kutatás reprezentatív jellegü. A mintámban csupán olyan serdülök vettek részt, akik rendszeresen sportolnak iskolán kívül, így valamennyien magas motivációval rendelkeztek a sport iránt. Érdekes lenne azonban megvizsgálni, hogy a csak testnevelésben résztvevő tanulóknak hogyan változik az elköteleződése. Ehhez mindenképp új mérőeszközök létrehozása szükséges mivel jelenleg nincs olyan elköteleződés vizsgáló kérdőív, mely a tanulók sport-iránti elköteleződését vizsgálná. Véleményem szerint a meglévő sport-elköteleződési skála minimális 
átalakítás után használható lehetne serdülő nem sportoló diákok számára is, mely a testnevelés órákon résztvevő diákoknak elköteleződést vizsgálná.

A disszertációban egy olyan témával foglalkoztam, mely viszonylag friss szakirodalommal bír, igy kutatásomat az is nehezítette, hogy e témában nem készültek hazai tanulmányok, amelyekkel eredményeimet összevethettem volna. Ugyanakkor az eltelt 4 évben az új változatú sport-elköteleződés modell számos nemzetközi publikációt termelt, igaz többnyire a kutatásaimmal párhuzamosan.

A vizsgálatomban csupán a serdülö korosztályra koncentráltam, ám érdekes lenne megvizsgálni a mintát idősebbeknél is. Érdekes lenne megvizsgálni, hogy a fiatal felnőtt korosztály, hogy köteleződik el egy-egy sportág iránt, hiszen napjaink „, fitnesz forradalma” őket érinti leginkább (gondoljunk arra, hogy ugrás szerủen megnőttek az utcai futó versenyekre jelentkezők száma, valamint, megjelentek az ún. „Spratan race”-ek melyek egy komplett szolgálást nyújtanak az amatőr sportolóknak).

Egy másik érdekes irány lehetne a jövőben longitudinális vizsgálatok készítése, hiszen találtunk rá példát a szakirodalomban, hogy az elköteleződés változhat az évek előre haladtával (Weiss és Weiss, 2004). Ez azért is lehetne egy fontos megközelítés, mert talán még tágabb képet kaphatnánk a sport-elköteleződés elemeinek fontosságáról.

A kutatás számos nyitott kérdést hagyott. Például érdekes lehetne megvizsgálni a sportelköteleződés kapcsolatát a kiégéssel, hiszen így még bővebb képet kaphatnánk a sportolói lemorzsolódásról, mely nagy mértékben növekszik a korral. Továbbá számos más egészségpszichológiai változó bevonásával a sportmotiváció és az egészség szerepét lehetne vizsgálni, hiszen kutatásomból látszik, hogy egyértelmủen hatással van rá. 


\section{KÖSZÖNETNYILVÁNÍTÁS}

Elsőként szeretném megköszöni témavezetőmnek dr. Pikó Bettinának az elmúlt évek áldozatos munkáját, folyamatos támogatását, útmutatásait és hogy szakmai segítségével nagymértékben hozzájárult a kutatás sikeréhez. Szeretném megköszöni továbbá a Neveléstudományi Doktori Iskola összes oktatójának, hogy szakmai tapasztalatukkal szélesítették érdeklödési körömet és a számtalan új ismeretet, melyekkel gazdagodhattam.

Szeretném megköszöni valamennyi hallgató társamnak is a folyamatos támogatást és hogy olyan környezetet teremtettek, melyben öröm volt együtt dolgozni.

Köszönet illeti a kutatásomban részt vett iskolákat is, akik segítő hozzáállásukkal lehetővé tették a vizsgálat elvégzését. Szeretnék köszöntetett mondani valamennyi testnevelő kollégámnak, akik óráikat feláldozva segítették az adatfelvételt. Így külön köszönöm Bakosi Béláné, Osvald Adrienn, Somogyi Nándor, Tóth Milán, és Vajda Zsuzsa munkáját.

Szeretném hálámat kifejezni Dr. Randy M Page-nek az angol nyelvű tanulmányaimhoz nyújtott támogatásáért.

És végül köszönöm feleségemnek, édesanyámnak, kisfiamnak, hogy a tanulmányaim és a kutató munkám alatt nyugodt légkört biztosítottak nekem. 


\section{IRODALOMJEGYZÉK}

Affentino, S. G. (2007): A missed opportunity. Journal of American Dietic Assoications, 107. 4. sz. $565-569$.

Agaku, I., Singh, T., Jones, S., King, B., Jamal, A., Neff, L. és mtsai. (2015): Combustible and smokeless tobacco use among high school athletes - united states, 2001-2013. morbidity and mortality weekly report, 64. 34. sz. 935-939.

Andersen, J., Gerds, T. A., Gislason, G., Schou, M., Torp-Pedersen, C., Hlatky, M. A. és mtsai (2020): Socioeconomic position and one-year mortality risk among patients with heart failure: A nationwide register-based cohort study. European Journal of Preventive Cardiology. 27. 1. sz. 79-88

Arem, H., Moore, S. C., Patel, A., Hartge, P., Berrington de Gonzalez, A., Visvanathan, K. és mtsai. (2015): Leisure time physical activity and mortality. JAMA Internal Medicine, 175. 6. sz. 959-967.

Atkin, M. R., Johnson, D., Force, C. E. és Petrie, T. A. (2015): Peers, parents, and coaches, oh my! The relation of the motivational climate to boys' intention to continue in sport. Psychology of Sport and Exercise, 16. 3. sz. 170-180.

Ács Pongrác és Kovács Ádám (2015): A fizikai aktivitás lényeges mutatóinak változása hazánkban és az Unióban az elmúlt négy év vonatkozásában. Magyar Sporttudományi Szemle, 16. 2. sz. 21.

Ádám Szilvia, Susánszky Éva és Szélyely András (2018): Egészség- és rizikómagatartás alakulása a Kárpát-medencei magyar fiatalok körében. In: Székely Levente (szerk.): Magyar fiatalok a Kárpát-Medencében. Magyar ifjúság 2016, Kutatópont KFT, Budapest. 508.

Beck, B. R., Daly, R. M., Singh, M. A. és Taaffe, D. R. (2017): Exercise and Sports Science Australia (ESSA) position statement on exercise prescription for the prevention and management of osteoporosis. Journal of Science and Medicine in Sport, 20. 5. sz. 438445 .

Baker, C. W., Little, T. D. és Brownell, K. D. (2003): Predicting adolescent eating and activity behaviors: the role of social norms and personal agency. Health Psychology, 22. 189198. 
Balázs Máté és Pikó Bettina (2016): Szociális hatások a serdülőkori dohányzásban: A szociális háttér, a család és a kortársak szerepe. Magyar Pedagógia, 116. 1. sz. 73-89.

Barcza-Renner, K., Eklund, R. C., Morin, A. J. és Habeeb, C. M. (2016): controlling coaching behaviors and athlete burnout: investigating the mediating roles of perfectionism and motivation. Journal of Sport and Exercise Psychology, 38. 1. sz. 30-44.

Bárdor Gábor és Kraiciné Szokoly Márta (2018): Egészség, életmód, egészségfejlesztés a felsőoktatás szemszögéböl. Neveléstudomány, 2. 5-21.

Bauman, A., Merom, D., Bull, F. C., Buchner, D. M. és Singh, F. (2016): Updating the evidence for physical activity: summative reviews of the epidemiological evidence, prevalence, and interventions to promote "active aging”. The Gerontologist, 56. 2. sz. S268-S280.

Banville, D., Desrosiers, P. és Genet-Volet, Y. (2000): Translating questionnaires and inventories using a cross-cultural translation technique. Journal of Teaching in Physical Education, 19.3. sz. 374-387.

Bearden, W., Netemeyer, R. és Haws, K. (2011): Handbook of marketing scales: Multi-item measures for marketing and consumer behavior research. Los Angeles: Sage Publications.

Borbás Ilona, Gődeny Sándor, Juhász Judit, Kincses Gyula, Mihalicza Péter, Pekli Márta és mtsai. (2008): Egészségtudományi fogalomtár. Gyógyszerészeti és Egészségügyi Minőség- és Szervezetfejlesztési Intézet Informatikai és Rendszerelemzési Főigazgatóság. https://fogalomtar.aeek.hu 2019. novemberi 18-i megtekintés

Borbély, Sz. (2014): As parents see physical education (PE) from a representative survey's point of view. In: Karlovitz J. T. (szerk.): Mozgás, környezet, egészség. International Research Institute. 39-54.

Boyst, J. (2009): An examination of sport commitment in collegiate athletes. The University of North Carolina. Greensboro.

Bradley, J., Keane, F. és Crawford, S. (2013): School sport and academic achievement. Journal of School Health, 83. 1. sz. 8-13.

Bradley, K. L., Goetz, T. és Viswanathan, S. (2018): Toward a contemporary definition of health. Military Medicine, 183. 3. sz. 204-207.

Brewer, B. W., Van Raalte, J. L. és Linder, D. E. (1993): Athletic identity: Hercules' muscles or Achilles' heel? International Journal of Sport Pychology, 24. 2. sz. 237-254. 
Brosnahan, J., Steffen, L. M., Lytle, L., Patterson, J. és Boostrom, A. (2004): The relation between physical activity and mental health among Hispanic and non-Hispanic white adolescents. Archives of Pediatrics \& Adolescent Medicine, 158. 18-23.

Bryant, F. B., és Satorra, A. (2012): Principles and practice of scaled difference chi-square testing. Structural Equation Modeling: A Multidisciplinary Journal, 19. 3. sz. 372-398.

Byrne, B. M. (2010): Structural equation modeling with AMOS: Basic concepts, applications and programming. London: Routledge

Burns, G. N., Jasinski, D., Dunn, S. C. és Fletcher, D. (2012): Athlete identity and athlete satisfaction: The nonconformity of exclusivity.Personality and Individual Differences, 52.3. sz. 280-284.

Butt, J., Weinberg, R. S., Breckon, J. D. és Claytor, R. P. (2011): Adolescent physical activity participation and motivational determinants across gender, age, and race. Journal of Physical Activity and Health, 8. 8. sz. 1074-1083.

Caglar, E., Canlan, Y. és Demir, M. (2009): Recreational exercise motives of adolescents and young adults. Journal of Human Kinetics, 22. 1.sz. 1-13.

Cameron, J., Banko, K. M. és Pierce, W. D. (2001): Pervasive negative effects of rewards on intrinsic motivation: The myth continues The Behavior Analyst, 24. 1. sz. 1-44.

Cameron, J., Pierce, W. D., Banko, K. M. és Gear, A. (2005): Achievement-based rewards and intrinsic motivation: A test of cognitive mediators. Journal of Educational Psychology, 97. 4. sz. 641-655.

Carpenter P. J., Scanlan T. K., Simons J. és Lobel M. (1993): A Test of the sport commitment model using structural equation modeling. Journal of Sport \& Exercise Psychology 15. 2. sz. $119-133$.

Carpenter, P. J. és Coleman, R. (1998): A longitudinal study of elite youth cricketers' commitment. International Journal of Sport Psychology, 29. 3.sz. 195-210.

Carré, J. M. és McCormick, C. M. (2008): Aggressive behavior and change in salivary testosterone concentrations predict willingness to engage in a competitive task. Hormones and Behavior, 54. 3.sz. 403-409.

Casper J. M., Gray, D. P. és Stellino B. S. (2007): A sport commitment model perspective on adult tennisplayers' participation frequencyand purchase intention. Sport Management Review, 10. 3. sz. 253-278. 
Casper, J. M. és Andrew, D. P. S. (2008): Sport commitment differences among tennis players on the basis of participation outlet and skill level. Journal of Sport Behavior, 31. 3. sz. 201-219.

Chantal, Y., Guay, F., Dobreva-Martinova, T. és Vallerand, R. J. (1996): Motivation and elite performance: An exploratory investigation with Bulgarian athletes. International Journal of Sport Psychology, 27. 2. sz. 173-182.

Chatzisarantis, N. L. D. és Hagger, M. S. (2007): The moral worth of sport reconsidered: Contributions of recreational sport and competitive sport to life aspirations and psychological well-being. Journal of Sport Sciences, 25. 9. sz. 1047-1056.

Chu, A. Y. és Wang, C. H. (2012): Differences in level of sport commitment among college dance sport competitors. Social Behavior and Personality: An international journal, $\mathbf{4 0 .}$ 5. sz. $755-766$.

Crane, J. és Temple, V. (2015): A systematic review of dropout from organized sport among children and youth. European Physical Education Review, 21. 1. sz. 114-131.

Cronin, L. D. és Allen, J. B. (2015): Developmental experiences and well-being in sport: The importance of the coaching climate. The Sport Psychologist, 29. 1 sz. 62-71.

Currant, T., Hill, A.P., és Williams, L. J. (2017): The relationship between parental conditional regard and adolescents self-critical and narcissistic perfectionism. Personality and Individual Differences, 109. 17-22.

Cronbach, L. J. (1951): Coefficient alpha and the internal structure of tests. Psychometrika, 16. 3. sz. $297-334$.

Csáki, I., Szakály, Z., Fózer-Selmec, B., Kiss, S. Z. és Bognár, J. (2017): Psychological and anthropometric characteristics of a hungarian elite football academy's players. Physical Culture and Sport. Studies and Research, 73. 1. sz. 15-26.

Csikszentmihalyi, M. (1997): Beyond boredom and anxiety. San Francisco, CA: Jossey-Bass.

Csizmadia Péter és Várnai Dóra (2003): Dohányzás és alkoholfogyasztás. In: Aszmann Anna (szerk.): HBSC Iskoláskorú gyermekek egészségmagatartása. Országos Gyermekegészségügyi Intézet, Budapest. 49-60.

Dahlgren, G. és Whitehead, M. (1991): Policies and strategies to promote social equity in health. Institute for Future Studies, Stockholm (Mimeo). 
Deci, E. L. és Ryan, R. M. (1985): Intrinsic motivation and self-determination in human behavior. New York, NY: Plenum Press.

Deci, E. L. és Moller, A. C. (2005): The concept of competence: A starting place for understanding intrinsic motivation and self-determined extrinsic motivation. In A. J. Elliot és C. J. Dweck (szerk.): Handbook of competence and motivation, New York: Guilford PressWorld Health Organisation. Regional Office for Europe. Copenhagen. 579.

Deci, E. L. és Ryan, R. M. (2000): The „what” and „why” of goal pursuits: human needs and the self-determination of behavior. Psychological Inquiry, 11. 4. sz. 227-268.

Deci, E. és Ryan, R. (2002): Handbook of self-determination. Rochester, NY: University of Rochester Press.

Deephouse, D. L. és Jaskiewicz, P. (2013): Do family firms have better reputations than nonfamily firms? an integration of socioemotional wealth and social identity theories. Journal of Management Studies, 50. 3. 337-360.

Diener, E., Emmons, R. A., Larsen, R. J. és Griffin, S. (1985): The Satisfaction with Life Scale. Journal of Personality Assessment, 49. 1. sz. 71-75.

Dobos Bianka és Pikó Bettina (2017): A zenei teljesítményszorongás összefüggése a perfekcionizmussal és a szociális fóbiával. Magyar Pedagógia, 117. 3. sz. 241-256.

Domínguez-Escribano, M., Ariza-Vargas, L. és Tabernero, C. (2015): Motivational variables involved in commitment of female soccer players at different competitive levels. Soccer \& Society, 18. 7. sz. 801-816.

Duda, J. L. és Treasure, D. C. (2010): Motivational processes and the facilitation of quality engagement in sport. In J.M. Williams (szerk.), Applied sport psychology: Personal growth to peak performance, New York, NY: McGraw-Hill. 59-80.

Dunkley, D. M., Zuroff, D. C. és Blankstein, K. R. (2003): Self-critical perfectionism and daily affect: Dispositional and situational influences on stress and coping. Journal of Personality and Social Psychology, 84. 1. sz. 234-252.

Eime, R. M., Young, J. A., Harvey, J.T., Charity, M. J. és Payne, W. R. (2013): A systematic review of the psychological and social benefits of participation in sport for children and adolescents: Informing development of a conceptual model of health through sport. International Journal of Behavioral Nutrition \& Physical Activity, 10. 1. sz. 98-118. 
Elekes, Zsuzsanna; Demetrovics, Zsolt; Domokos, Tamás; Király, Orsolya; Nyírády, Adrienn; Zsila, Ágnes (2016): Európai iskolavizsgálat az alkohol- és egyéb drogfogyasztási szokásokról - 2015.: Magyarországi eredmények. Budapest, Magyarország: Budapesti Corvinus Egyetem Szociológia és Szociálpolitika Intézet, 274.

Erikson, E. H. (1994): Identity and the Life Cycle. New York, NY: W. W. Norton \& Company. Eurobarometer (2018): Special Eurobarometer 472 - Sport and physical activity. Brussel: European Union.

Evans, P. (2015): Self-determination theory: An approach to motivation in music education. Musicae Scientiae, 19. 1. sz. 65-83.

Fairclough, S. és Stratton, G. (2005): Improving health-enhancing physical activity in girls' physical education. Health Education Research. 20. 4. sz. 448-457.

Fintor Gábor (2017): A mindennapos tanórai testnevelés szubjektív helyzete az észak-alföldi régió tanulóinak körében. Magyar Sporttudományi Szemle. 18. 4. sz. 4-10.

Frederick, C. M., és Ryan, R. M. (1993): Differences in motivation for sport and exercise and their relations with participation and mental health. Journal of Sport Behavior, 16. 3. sz. $124-146$.

Frost, R. O., Marten, P., Lahart, C. és Rosenblate, R. (1990): The dimensions of perfectionism. Cognitive Therapy and Research, 14. 449-468.

Fóti Ákos, Budainé Csepela Yvette és Borosán Lívia (2019): A Komplex Instrukciós Program alkalmazásának pedagógiai tapasztalatai és dilemmái a testnevelés órákon. In: Hamar Pál (szerk.): 49. MOZGÁSBIOLÓGIAI KONFERENCIA. Program, elöadás-kivonatok. Testnevelési egyetem, Budapest, 23-24.

Fülöp Nikoletta és Szakály Zoltán (2008): Fiatalok táplálkozási szokásai, egészségmagatartásaSzekunder kutatás. Élelmiszer, Táplálkozás és Marketing, 5. 1. sz. 81-86.

Gabriele, J. M., Gill, D. L. és Adams, C. E. (2011): The roles of want to commitment and have to commitment in explaining physical activity behavior. Journal of Physical Activity and Health, 8. 3. sz. 420-428.

Gagne, M. (2014): The Oxford Handbook of Work Engagement, Motivation, and SelfDetermination Theory. New York, NY: Oxford University Press, USA.

Garson, G. D. (2015): Structural equation modeling. Asheboro, NC: Statistical Associates Publishers 
Gáspár, Z., Soós, I., és Szabo, A. (2017): Is there a link between the volume of physical exercise and emotional intelligence (EQ)? Polish Psychological Bulletin, 48. 1. sz. $105-110$.

Gaudreau, P. és Thompson, A. (2010): Testing a 2 X 2 model of dispositional perfectionism. Personality and Individual Differences, 48. 5. sz. 532-537.

Gero, K., Iso, H., Kitamura, A., Yamagishi, K., Yatsuya, H. és Tamakoshi, A. (2018): Cardiovascular disease mortality in relation to physical activity during adolescence and adulthood in Japan: Does school-based sport club participation matter? Preventive Medicine, 113. 102-108.

Géczi, G., Vincze, G., Koltai, M. és Bognár, J. (2009): Elite young team players' coping, motivation and perceived climate measures. Physical Culture and Sport. Studies and Research, 46. 1. sz. 229-242.

Gillison, F., Osborn, M., Standage, M. és Skevington, S. (2009): Exploring the experience of introjected regulation for exercise across gender in adolescence. Psychology of Sport and Exercise, 10. 3. sz. 309-319.

Grant, N., Wardle, J. és Steptoe, A. (2009): The relationship between life satisfaction and health behavior: A cross-cultural analysis of young adults. International Journal of Behavioral Medicine, 16. 3. sz. 259-268.

Griethuijsen, R. A. L. F., Eijck, M. W., Haste, H., Brok, P. J., Skinner, N. C. és Mansour, N. (2014): Global patterns in students' views of science and interest in science. Research in Science Education, 45. 4. sz. 581-603.

Gombocz János. (2019): A testnevelés, az iskolai sport. Új Pedagógiai Szemle, 69. 3-4. sz. 715.

Gotwals, J. K. (2016): The tripartite model of perfectionism: Evidence from research in sport and dance. In: Hill, A.P. (szerk.) The psychology of perfectionism in sport, dance and exercise. Routledge, 150-173.

Gunnell, K. E., Crocker, P. R., Mack, D. E., Wilson, P. M. és Zumbo, B. D. (2014): Goal contents, motivation, psychological need satisfaction, well-being and physical activity: A test of self-determination theory over 6 months. Psychology of Sport and Exercise, 15. 1. sz. 19-29. 
Gurková, E., Haroková, S., Džuka, J. és Žiaková, K. (2013): Job satisfaction and subjective well-being among Czech nurses. International Journal of Nursing Practice, 20. 2. sz. 194-203.

Gyömbér Noémi és Kovács Krisztina (2012): Pici lábak a pályán, avagy a fiatalkori sport pszichológiája. In: Gyömbér Noémi és Kovács Krisztina (szerk.): Fejben dől el. Sportpszichológia mindenkinek. NORAN LIBRO, Budapest, 191-120.

Hair, J. F., Jr., Black, W. C., Babin, B. J. és Anderson, R. E. (2009): Multivariate data analysis (7th ed.). Upper Saddle River, NJ: Prentice Hall.

Halvari, A. E. M., Halvari, H., Bjørnebekk, G. és Deci, E. L. (2010): Motivation and anxiety for dental treatment: Testing a self-determination theory model of oral self-care behaviour and dental clinic attendance. Motivation and Emotion, 34. 15-33.

Hashim, H. A., Grove, R. és Whipp, P. (2008): Validating the youth sport enjoyment construct in high hchool physical rducation. Research Quarterly for Excercise and Sport, 79. 2. SZ. 183-194.

Hawkins, R. D., Hulse, M.A., Wilkinson, C., Hodgson, A. és Gibson, M. (2001): The association football medical research program: an audit of injuries in professional football. British Journal of Sports Medicine, 34. 1. sz. 43-47.

Hídvégi Péter és Bíró Melinda (2015): Egészségfejlesztés. Eger: EKF Líceum Kiadó.

Hill, A. P. és Madigan, J. D. (2017): A short review of perfectionism in sport, dance and exercise: Out with the old, in with the 2 X 2. Current Opinion in Psychology, 16. 72-77.

Ho, C., Huang, Y., Lo, Y. C., Wahlqvist, M. L. és Lee, M. (2015): Breakfast is associated with the metabolic syndrome and school performance among Taiwanese children. Research in Developmental Disabilities, 43-44. 179-188.

Hodder, R., Campbell, E., Gilligan, C., Lee, H., Lecathelinaisi, C., Green, S. és mtsai. (2018): Associations between adolescent tobacco and alcohol use, and tobacco and alcohol use risk and protective factors. International Society of Behavioral Medicine, 25. 1. sz. 149.

Hooper, D., Coughlan, J. és Mullen, M. R. (2008): Structural equation modelling: Guidelines for determining model fit. Journal of Business Research Methods, 6. 53-60.

Hu, L. és Bentler, P. M. (1999): Cut-off criteria for indexes in covariance structure analysis: Conventional criteria versus new alternatives. Structural Equation Modelling, 6. 1. sz.155. 
Huang, C., Wang, Y., Wu, T. és Wang, P. (2013): An empirical analysis of the antecedents and performance consequences of using the moodle platform. International Journal of Information and Education Technology, 3. 2. sz. 217-221.

Jaakkola, T., Ntoumanis, N. és Liukkonen, J. (2015): Motivational climate, goal orientation, perceived sport ability, and enjoyment within Finnish junior ice hockey players. Scandinavian Journal of Medicine \& Science in Sports, 26. 1. sz. 109-115.

Jafarirad, S., Mousavi Borazjani, A., Fathi, M. és Hormoznejad, R. (2016): A study on anthropometric measurements, blood pressure, blood sugar and food intakes among different social status and ethnicities. Jundishapur Journal of Chronic Disease Care, 6. 1. sz. e38916

Jakobsen, A. M. (2014): Are there differences in motives between participants in individual sports compared to team sports? LASE Journal of Sport Science, 5. 2. sz. 30-40.

Jernigan, D., Noel, J., Landon, J., Thornton, N. és Lobstein, T. (2016): Alcohol marketing and youth alcohol consumption: A systematic review of longitudinal studies published since 2008. Addiction, 112. 1. sz. 7-20.

Joireman, J., Shaffer, M. J., Balliet, D. és Strathman, A. (2012): promotion orientation explains why future-oriented people exercise and eat healthy. Personality and Social Psychology Bulletin, 38. 10. sz. 1272-1287.

Kajbafnezhad, H., Ahadi, H., Heidarie, A. R., Askari, P. és Enayati, M. (2011): Difference between team and individual sports with respect to psychological skills, overall emotional intelligence and athletic success motivation in Shiraz city athletes. Journal of Physical Education \& Sport, 11. 3.sz. 249-254.

Kasser, T. és Ryan, R. M. (1996): Further examining the American dream: Differential correlates of intrinsic and extrinsic goals. Personality and Social Psychology Bulletin, 22. 3. sZ. 280-287.

Keski-Rahkonen, A., Kaprio, J., Rissanen, A., Virkkunen, M. és Rose, R. J. (2003): Breakfast skipping and health-compromising behaviors in adolescents and adults. EuropeanJournal of Clinical Nutrition, 57. 7. sz. 842-853.

Keresztes Noémi, Pluhár Zsuzsanna és Pikó Bettina (2003): A fizikai aktivitás gyakorisága és sportolási szokások általános iskolások körében. Magyar Sporttudományi Szemle, 4. 4347. 
Kiefer, S. M. és Ryan, A. M. (2011): Students' perceptions of characteristics associated with social success: Changes during early adolescence. Journal of Applied Developmental Psychology, 32. 4. sz. 218-226.

Kimm, S. Y., Glynn, N. W., Kriska, A. M., Fitzgerald, S. L., Aaron, D. J., Similo, S. és Barton, B. A. (2000): Longitudinal changes in physical activity in a biracial cohort during adolescence. Medicine \& Science in Sports \& Exercise, 32. 8. sz. 1445-1454.

Klibert, J., Lamis, D. A., Naufel, K., Yancey, C. T. és Lohr, S. (2015): Associations between perfectionism and generalized anxiety: Examining cognitive schemas and gender. Journal of Rational-Emotional \& Cognitive-Behavior Therapy, 33. 2. sz. 160-178.

Kyriazos, T. A. (2018): Applied Psychometrics: The 3-faced construct validation method, a routine for evaluating a factor structure. Psychology, 9.8 sz. 2044-2072.

Lacorte, E., Ferrigno, L., Leoncini, E., Corbo, M., Boccia, S. és Vanacore, N. (2016). Physical activity, and physical activity related to sports, leisure and occupational activity as risk factors for ALS: A systematic review. Neuroscience \& Biobehavioral Reviews, 66. 6179.

Lavigne, G. L., Hauw, N., Vallerand, R. J., Brunel, P., Blanchard, C., Cadorette, I. és mtsai. (2009): On the dynamic relationships between contextual (or general) and situational (or state) motivation toward exercise and physical activity: A longitudinal test of the topdown and bottom-up hypotheses. International Journal of Sport and Exercise Psychology, 7.2. sz. 147-168.

Lalonde, M. (1974): A new perspective on the health of Canadians: a working document. Ottawa. Government of Canada.

Lamont-Mills, A. és Christensen, S. A. (2006): Athletic identity and its relationship to sport participation levels. Journal of Science and Medicine in Sport, 9. 6. sz. 472-478.

Lee, J. Q., McInerney, D. M., Liem, G. A. és Ortiga, Y. P. (2010): The relationship between future goals and achievement goal orientations: An intrinsic-extrinsic motivation perspective. Contemporary Educational Psychology, 35. 4. sz. 264-279.

Leech, R. M., McNaughton, S. A., és Timperio, A. (2014): The clustering of diet, physical activity and sedentary behavior in children and adolescents: a review. International Journal of Behavioral Nutrition and Physical Activity, 11. 1. sz. 4. 
Levine, S. L. és Milyavskaya, M. (2018): Domain-specific perfectionism: An examination of perfectionism beyond the trait-level and its link to well-being. Journal of Research in Personality, 74. 56-65.

Lim, S. S., Vos, T., Flaxman, A. D., Danaei, G., Shibuya, K., Adair-Rohani, H. és mtsai. (2012): A comparative risk assessment of burden of disease and injury attributable to 67 risk factors and risk factor clusters in 21 regions, 1990- 2010: a systematic analysis for the Global Burden of Disease Study 2010. Lancet, 380. 9859 sz. 2224-2260.

Limburg, K., Watson, H. J., Hagger, M. S. és Egan, S. J. (2017): The relationship between perfectionism and psychopathology: A metaanalysis. Journal of Clinical Psychology, 73. 10. sz. $1301-1326$.

Locke, E. A. és Latham, G. P. (1985): The application of goal setting to sports. Journal of Sport Psychology, 7. 3. sz. 205-222.

Lyubomirsky, S., King, L. és Diener, E. (2005): The benefits of frequent positive affect: Does happiness lead to success? Psychological Bulletin, 131. 6. sz. 803-855.

MacDonald, D. J., Côté, J., Eys, M. és Deakin, J. (2011): The role of enjoyment and motivational climate in relation to the personal development of team sport athletes, The Sport Psychologist, 25. 1. sz. 32-46.

Malhotra, N. K. és Dash, S. (2011): Marketing research: An applied orientation. London: Pearson Publishing.

Madigan, D. J., Stoeber, J., Forsdyke, D., Dayson, M. és Passfield, L. (2018): Perfectionism predicts injury in junior athletes: Preliminary evidence from a prospective study. Journal of Sport Sciences, 36. 5. sz. 545-550.

Madigan, D. J., Stoeber, J., és Passfield, L. (2016): Perfectionism and changes in athlete burnout over three months: Interactive effects of personal standards and evaluative concerns perfectionism. Psychology of Sport and Exercise, 26. 32-39.

Martin, L. A., Fogarty, G. J. és Albion, M. J. (2013): changes in athletic identity and life satisfaction of elite athletes as a function of retirement status. Journal of Applied Sport Psychology, 26. 1. sz. 96-110.

Martos, T., Sallay, V., Désfalvy, J., Szabó, T. és Ittzés, A. (2014): Psychometric characteristics of the Hungarian version of the Satisfaction with Life Scale (SWLS-H): Hungarian Journal of Mental Health and Psychosomatics, 15. 3. sz. 289-303. 
Martos, T., Szabó, G. és Rózsa, S. (2006): Psychometric characteristics of the Shortened Aspiration Index in Hungarian sample. Hungarian Journal of Mental Health and Psychosomatics, 7. 3. sz. 171-191.

Matarazzo, J.D. (1980): Behavioral health and behavioral medicine: Frontiers for a new health psychology. American Psychologist, 35. 9. sz. 807-817.

Masten, R., Dimec, T., Donko I. A. és Tusak M. (2010): Motives for sport participation, attitudes to sport and general health status of slovenian armed forces emplyees. Kinesiology, $\mathbf{4 2}$. 2. sz. $153-163$.

McKelvey, K. és Halpern-Felsher, B. (2017): Adolescent cigarette smoking perceptions and behavior: tobacco control gains and gaps amidst the rapidly expanding tobacco products market from 2001 to 2015. Journal of Adolescent Health, 60. 2. sz. 226-228.

McCarthy, P. J., Jones M. V. és Clark-Carter, D. (2008): Understanding enjoyment in youth sport: A developmental perspective. Psychology of Sport and Exercise, 9. 2. sz. 142156.

McCreary, D. R., Saucier, D. M. és Courtenay, W. H. (2005): The drive for muscularity and masculinity: Testing the associations among gender-role traits, behaviors, attitudes, and conflict. Psychology of Men \& Masculinity, 6. 2. sz. 83-94.

Meier, T., Gräfe, K., Senn, F., Sur, P., Stangl, G. I., Dawczynski, C. és mtsai. (2018): Cardiovascular mortality attributable to dietary risk factors in 51 countries in the WHO European Region from 1990 to 2016: A systematic analysis of the Global Burden of Disease Study. European Journal of Epidemiology, 34. 1. sz. 37-55.

Meleg Csilla (2002): Iskolai egészségnevelés: a feladat újrafogalmzása. Magyar Pedagógia, 102. 1. sz. 11-29.

Meyer, J. P. és Herscovitch, L. (2001): Commitment in the workplace: Toward a general model. Human Resource Management Review, 11. 3. sz. 299-326.

Mikulán Rita és Pikó Bettina (2012): Iskoláskorú sportoló fiatalok káros szenvedélyeinek vizsgálata sportmotivációik és a sportáguk típusa tükrében. Iskolakultúra, 22. 4. sz. 3549.

Mikulán Rita (2007): Serdülökorú versenysportolók egészségének és egészségmagatartásának vizsgálata. Magyar Sporttudományi Szemle, 8. 30 sz. 8-11. 
Milyavskaya, M. és Koestner, R. (2011): Psychological needs, motivation, and well-being: A test of self-determination theory across multiple domains. Personality and Individual Differences, 50. 3. sz. 387-391.

Miquelon, P., Vallerand, R. J., Grouzet, F. M. és Cardinal, G. (2005): perfectionism, academic motivation, and psychological adjustment: an integrative model. Personality and Social Psychology Bulletin, 31. 7. sz. 913-924.

Mistretta, E. G., Glass, C. R., Spears, C. A., Perskaudas, R., Kaufman, K. A. és Hoyer, D. (2017). Collegiate athletes' expectations and experiences with mindful sport performance enhancement. Journal of Clinical Sport Psychology, 11. 3. sz. 201-221.

Molanorouzi, K., Khoo, S. és Morris, T. (2014). Validating the Physical Activity and Leisure Motivation Scale (PALMS). BMC Public Health, 14. 1. sz. 1-15.

N. Kollár Katalin és Szabó Éva (2004): Pszichológia pedagógusoknak. Budapest: Osiris Kiadó.

Nagy Lászlóné és Barabás Katalin (2011): Az egészségműveltség és egészségmagatartás diagnosztikus mérésének lehetőségei. In: Csapó Benő és Zsolnai Anikó (szerk.): Kognitív és affektív fejlödési folyamatok diagnosztikus értékelésének lehetöségei az iskola kezdö szakaszában. Nemzeti Tankönyvkiadó, Budapest, 173-224.

Nagy, Á., Fintor, G. és Borbély, Sz. (2015): Changing values in body culture; significance of everyday physical education in shaping young adults' views on sports and health first part. Recreation, 5. 2. sz. 23-26.

Németh Ágnes (2003): Nemi érés és szexuális magatartás. In: Aszmann Anna (szerk.): HBSC Iskoláskorú gyermekek egészségmagatartása. Országos Gyermekegészségügyi Intézet, Budapest. 77-76.

Németh Ágnes (2011): Táplálkozási szokások és fogápolás. In: Németh Ágnes és Költő András (szerk.): Serdülökorú fiatalok egészsége és életmódja 2010. Az Iskoláskorú gyermekek egészségmagatartása címü, az Egészségügyi Világszervezettel együttmüködésben zajló nemzetközi kutatás 2010. évi felméréséről, 21-25

Németh Ágnes (2014): Táplálkozási szokások és fogápolás. In.: Német Ágnes és Költő István (szerk): Egészség és egészségmagatartás iskoláskorban. Az Iskoláskorú gyermekek egészségmagatartása címü, az Egészségügyi Világszervezettel együttmüködésben zajló nemzetközi kutatás 2014. évi felméréséről, 28-30 
Neulinger Ágnes (2009): A szabadidő-sport iránti érdeklődés Magyarországon. Magyar Sporttudományi Szemle, 10. 39-40. sz. 29-32

Neumark-Sztainer, D., Larson, N. I., Fulkerson, J. A., Eisenberg, M. E. és Story, M. (2010): Family meals and adolescents: What have we learned from Project EAT (Eating Among Teens)? Public Health Nutrition, 13. 7. sz. 1113-1121.

Ng, J. Y., Ntoumanis, N., Thøgersen-Ntoumani, C., Deci, E. L., Ryan, R. M., Duda, J. L. és Williams, G. C. (2012): Self-Determination Theory Applied to Health Contexts. Perspectives on Psychological Science, 7. 4. sz. 325-340.

Nurmi, J. E. (1991): How do adolescents see their future? A review of the development of future orientation and planning. Developmental Review, 11. 1. sz. 1-59

Ong, N. C. (2017): Assessing objective achievement motivation in elite athletes: A comparison according to gender, sport type, and competitive level. International Journal of Sport and Exercise Psychology, 17. 4. sz. 397-409

Olds, T., Wake, M., Patton, G., Ridley, K., Waters, E., Williams, J. és mtsai. (2009): How do school-day activity patterns differ with age and gender across adolescence? Journal of Adolescent Health, 44. 1. sz. 64-72.

Orosz Éva: Félúton vagy tévúton? Egészségügyünk félmúltja és az egészségpolitika alternatívái, Egészséges Magyarországért Egyesület Budapest, 2001.

Osborne, V., Serdarevic, M., Crooke, H., Striley, C. és Cottler, L. B. (2017): Non-medical opioid use in youth: Gender differences in risk factors and prevalence. Addictive Behaviors, 72. 114-119.

Pallant, J. (2010): Spss Survival Manual: A step by step guide to data analysis using SPSS, Open University Press, Milton Keynes, UK

Pataki Ferenc (1982): Az én és a társadalmi azonosságtudat. Kossuth kiadó, Budapest.

Patterson, M. M., Carron, A. V. és Louhead, T. M. (2005): The influence of team norms on the cohesion - self reported performance relationship: A multi-level analysis. Psychology of Sport and Exercise, 6. 4. sz. 479-493.

Pálmai Judit (2017): A holisztikus egészségfogalom felé. In: Lippai László (szerk.): Testmozgásfókuszú egészségnevelés kortárscsoportban: Holisztikus egészség, egészségmagatartás és egészségfejlesztés, Szegedi Tudományegyetem Juhász Gyula 
Pedagógusképző Kar Alkalmazott Egészségtudományi és Egészségfejlesztési Intézet, Szeged, 33-36.

Peake, J. M., Neubauer, O., Walsh, N. P. és Simpson, R. J. (2017): Recovery of the immune system after exercise. Journal of Applied Psychology, 122. 1077-1087.

Pelletier, L. G., Tuson, K. M., Fortier, M. S., Vallerand, R. J., Briére, N. M. és Blais, M. R. (1995): Toward a new measure of intrinsic motivation, extrinsic motivation, and amotivation in sports: The Sport Motivation Scale (SMS): Journal of Sport and Exercise Psychology, 17. 1. sz. 35-53.

Pelletier, L. G., Rocchi, M. A., Vallerand, R. J., Deci, E. L. és Ryan, R. M. (2013): Validation of the revised Sport Motivation Scale (SMS-II). Psychology of Sport and Exercise, 14. 3. sz. 329-341.

Peretti-Watel, P., Guagliardo, V. és Verger, P. (2003): Sporting activity and drug use: Alcohol, cigarette and cannabis use among elite student athletes. Addiction, 98. 9. sz. 1249-1256.

Pénzes Gabriella és Bíró Éva (2018): Egészségfejlesztő program középiskolások körében - Az alapállapot felmérés eredményei. Egészségfejlesztés, 59. 4. sz. 7-16.

Paic, R., Kajos, A., Meszler, B. és Prisztóka, G. (2017): Validation of the Hungarian Sport Motivation Scale (H-SMS). Cognition, Brain, Behavior. An Interdisciplinary Journal, 21. 4. sz. 275-291.

Pinder, C. C. (1998): Motivation in work organizations. Upper Saddle River, NJ: Prentice Hall.

Puente, R. és Anshel, M. H. (2010): Exercisers' perceptions of their fitness instructor's interacting style, perceived competence, and autonomy as a function of self-determined regulation to exercise, enjoyment, affect, and exercise frequency. Scandinavian Journal of Psychology, $\mathbf{5 1 .} 1$ sz. 38-45.

Raedeke, T. D. (1997): Is athlete burnout more than just stress? A sport commitment perspective. Journal of Sport and Exercise Psychology, 19. 4. sz. 396-417.

Rauner, A., Mess, F. és Woll, A. (2013): The relationship between physical activity, physical fitness and overweight in adolescents: A systematic review of studies published in or after 2000. BMC Pediatrics, 13. 1. sz. 13-19.

Rábai Dávid (2016): Élet a labdarúgó akadémiákon - egy pilot kutatás eredményei. In.: Farkas Evelin Nagy, Jenő Polyák, Enikő, Szabó Éva (szerk.): „A mi tendenciáink...” Szakkollégiumi tanulmányok, 4. 70-85. 
Reinboth, M. és Duda, J. L. (2006): Perceived motivational climate, need satisfaction and indices of well-being in team sports: A longitudinal perspective. Psychology of Sport and Exercise, 7. 3. sz. 269-286.

Ruiz, L. D. és Scherr, R. E. (2018): Risk of energy drink consumption to adolescent health. American Journal of Lifestyle Medicine, 13. 1. sz. 22-25.

Rusbult, C. E. (1980a): Commitment and satisfaction in romantic associations: A test of the investment model. Journal of Experimental Social Psychology, 16. 2. sz. 172-186.

Rusbult, C. E. (1980b): Satisfaction and commitment in friendships. Representative Researching Social Psychology. 11.2. sz. 96-105

Rusbult, C. E. (1981): A longitudinal test of the investment model: The development (and deterioration) of satisfaction and commitment in heterosexual involvements. Journal of Personality and Social Psychology, 45. 1. sz. 101-117.

Rusbult, C. E. és Farrell, D. (1983): A longitudinal test of the investment model: The impact of job satisfaction, job commitment, and turnover of variations in rewards, costs, alternatives and investments. Journal of Applied Psychology, 68. 3. sz. 429-438.

Ryan, R. M. és Deci, E. L. (2000): Self-determination theory and the facilitation of intrinsic motivation, social development, and well-being. American Psychologist, 55. 1. sz. 6878.

Ryan, R. M. és Deci, E. L. (2017): Goal contents theory: Aspirations, life goals, and their varied consequences. In Self-determination theory: Basic psychological needs in motivation, development, and wellness, Guildford, New York.

Ryan, R. M., Patrick, H., Deci, E. L. és Williams, G. C. (2008): Facilitating health behaviour change and its maintenance: Interventions based on self-determination theory. European Health Psychologist, 10. 1. sz. 2-5.

Sabiston, C. M., O'Loughlin, E., Brunet, J., Chaiton, M., Low, N.C., Barnett, T. és mtsai. (2013): Linking depression symptom trajectories in adolescence to physical activity and team sports participation in young adults. Preventive Medicine, 56. 2. sz. 95-98.

Santos, A. J. és Gonçalves, C. E. (2012): Tradução do Sources of enjoyment in youth sport questionnaire do development assents profile para jovens atletas portugueses. Annals of Research in Sport and Physical Activity, 3. 9-36. 
Sánchez-Miguel, P. A., Chow, G. M., Sousa, C., Scanlan, T. K., Ponseti, F. J., Scanlan, L. és García-Mas, A. (2019): Adapting the Sport Commitment Questionnaire-2 for Spanish Usage. Perceptual and Motor Skills, 126. 2. sz. 267-285.

Scanlan T. K., Carpenter P. J., Lobel M, és Simons J. P. (1993): Sources of Enjoyment for Youth Sport Athletes. Pediatric Exercise Science, 5. 3. sz. 275-285.

Scanlan, T. K., Ravizza, K. és Stein G. L. (1989): An in-dept study of former elit figure skaters: I. intruducition to the project. Journal of Sport and Excercise Psychology 11. 1. sz. 5664.

Scanlan, T. K., Carpenter, P. J., Schmidt, G. W. és Simons, J. P. (1993): The sport commitment model: measurement development for the youth sport domain. Journal of Sport \& Exercise Psychology, 15. 1. sz. 16-39.

Scanlan, T. K., Carpenter, P. J., Schmidt, G. W., Simons, J. P. és Keeler, B. (1993): An introduction to the sport commitment model. Journal of Sport \& Exercise Psychology, 15. 1 . sz. $1-15$.

Scanlan, T. K., Russell, D. G., Magyar, T. M. és Scanlan, L. A. (2009): Project on Elite Athlete Commitment (PEAK): III. An examination of the external validity across gender, and the expansion and clarification of the Sport Commitment Model. Journal of Sport \& Exercise Psychology, 31. 6. sz. 685-705.

Scanlan, T. K., Russell, D. G., Scanlan, L. A., Klunchoo, T. J. és Chow, G. M. (2013): Project on Elite Athlete Commitment (PEAK) IV.: Identification of new candidate commitment sources for the Sport Commitment Model. Journal of Sport and Exercise Psychology, 35. 5. sz. $525-535$.

Scanlan, T. K., Graig M.., Sousa C., Scanlan L. és Knifsend C. A. (2016): The development of Sport Commitment Questionnaire-2. Psychology of Sport and Exercise, 22. 233-246.

Scanlan, T. K., Russell, D. G., Beals, K. P. és Scanlan, L. A. (2003): Project on Elite Athlete Commitment (PEAK): II. A direct test and expansion of the Sport Commitment Model with elite amateur sportsmen. Journal of Sport \& Exercise Psychology, 25. 3. sz. 377401.

Shachaf, M., Katz, Y. J. és Shoval, E. (2013): The unique trio: academic achievement sport, and gender. Education \& Society, 31. 1. sz. 17-36. 
Sheehan, R. B., Herring, M. P. és Campbell, M. J. (2018): Longitudinal relations of mental health and motivation among elite student-athletes across a condensed season: Plausible influence of academic and athletic schedule. Psychology of Sport and Exercise, 37. 146152.

Sheikh, M. (2015): How different sports establish different athletic identity levels. International Journal of Kinesiology and Sports Science, 3. 3. sz. 28-32.

Sheldon, K. M., Ryan, R. M., Deci, E. L. és Kasser, T. (2004): The independent effects of goal contents and motives on well-being: It's both what you pursue and why you pursue it. Personality and Social Psychology Bulletin, 30. 4. sz. 475-486.

Sousa, C., Torregrosa, M., Viladrich, C., Villamarín, F. és Cruz, J. (2007): The commitment of young soccer players. Psicothema, 19. 2. sz. 256-262.

Stoeber, J., Otto, K. (2006): Positive conceptions of perfectionism: Approaches, evidence, challenges. Personality and Social Psychology Review, 10. 295-319.

Stone, A. A., Schwartz, J. E., Broderick, J. E. és Deaton, A. (2010): A snapshot of the age distribution of psychological well-being in the United States. Proceedings of the National Academy of Sciences, 107. 4. sz. 22. sz. 9985-9990.

Stuntz, C. P.és Weiss, M. R. (2009): Achievement goal orientations and motivational outcomes in youth sport: The role of social orientations. Psychology of Sport and Exercise, 10. 2. sz. 255-262.

Strachan, S. M., Fortier, M. S., Perras, M. G. és Lugg, C. (2013): Understanding variations in exercise-identity strength through identity theory and self-determination theory, International Journal of Sport and Exercise Psychology, 11. 3. sz. 273-285.

Strathman, A., Gleicher, F., Boninger, D. S. és Edwards, C. S. (1994): The consideration of future consequences: Weighing immediate and distant outcomes of behavior. Journal of Personality and Social Psychology, 66. 747-752.

Szemes Ágnes, Harsányi Szabolcs Gergő és Tóth László (2016): Különböző sportágakban versenyző sportolók sportmotivációjának és flow élményének összehasonlító vizsgálata. Testnevelés, Sport, Tudomány, 1. 1. sz. 80-90.

Szuhi Attila (2010): A szálló por okozta járulékos halálozás 22 hazai városban. Tájökológiai Lapok, 8. 3. sz. 411-420. 
Taliaferro, L., Rienzo, B. és Donovan, K. (2010): Relationships between youth sport participation and selected health risk behaviors from 1999 to 2007. The Journal of School Health, 80. 8. sz. 399-410.

Taylor, L. C., Burke, B., Donohue, J. E., Yu, S., Hirsch-Romano, J. C., Ohye, R. G. és mtsai. (2015): Risk factors for interstage mortality following the norwood procedure: impact of sociodemographic factors. Pediatric Cardiology, 37. 1. sz. 68-75.

Tekman, H. G. és Hortaçsu, N. (2002): Music and social identity: Stylistic identification as a response to musical style. International Journal of Psychology, 37. 5. sz. 277-285.

Terry-Short, L. A., Glynn Owens, G., Slade, P. D. és Dewey, M. E. (1995): Positive and negative perfectionism. Personality and Individual Differences, 18. 1. sz. 663-668.

Timlin, M. T., Pereira, M. A., Story, M. és Neumark-Sztainer, D. (2008): Breakfast eating and weight change in a 5-year prospective analysis of adolescents: Project EAT (Eating Among Teens): Pediatrics, 121. 3. sz. 638-645.

Trejos-Castillo, E. és Vazsonyi, A. T. (2011): Transitions into adolescence. In.: Brown, B. B. és Prinstein, M. (szerk.): Encyclopedia of Adolescence, Academic Press, San Diego, USA, 369-375.

Van Dusen, D. P., Kelder, S. H., Kohl, H. W., Ranjit, N. és Perry, C. L. (2011): Associations of physical fitness and academic performance among schoolchildren. Journal of School Health, 81. 12. sz. 733-740.

Varga-Hatos Katalin. és Karner Cecília (2008): A lakosság egészségi állapotát befolyásoló tényezők. Egészségügyi Gazdasági Szemle, 2. 25-33.

Vereecken, C., Pedersen, T. P., Ojala, K., Krolner, R., Dzielska, A., Ahluwalia, N. és mtsai. (2015): Fruit and vegetable consumption trends among adolescents from 2002 to 2010 in 33 countries. The European Journal of Public Health, 25. 2. sz. 16-19.

Vitrai János és Varsányi Péter (szerk.) (2015): Egészségjelentés 2015. Nemzeti egészségfejlesztési intézet, Budapest.

Vlachopoulos, S. P., Kaperoni, M. és Moustaka, F. C. (2011): The relationship of self determination theory variables to exercise identity. Psychology of Sport and Exercise, 12. 3. sz. 265-272.

V. Komlósi, A., Rózsa, S., Berdi, M., Móricz, E. és Horváth, D. (2006): Results of the Hungarian adaptation of Aspiration Index. Hungarian Journal of Psychology, 61. 237-250. 
Walker, D. és Howe, C. (2017): The AMA Communication Techniques Survey: A Psychometric Analysis. HLRP: Health Literacy Research and Practice, 1. 4. sz. $208-215$.

Wang, C. H. (2016): Older adults participation in ball room dancing: Partical application of the sport commitment model. Social Behavior and Personality 44. 3. sz. 445-452

Weiss, W. M. és Weiss, M. R. (2003): Attraction- and entrapment-based commitment among competitive female gymnasts. Journal of Sport and Exercise Psychology, 25. 2. sz. 229247.

Weiss, W. M. és Weiss, M. R. (2006): A longitudinal analysis of commitment among competitive female gymnasts. Psychology of Sport and Exercise, 7. 3. sz. 309-323.

Weiss, W. M., Weiss, M. R. és Amorose, A. J. (2010): Sport commitment among competitive female athletes: Test of an expanded model. Journal of Sports Sciences, 28. 4. sz. 423434.

Weisz, C. és Wood, L. F. (2005): Social identity support and friendship outcomes: A longitudinal study predicting who will be friends and best friends 4 years later. Journal of Social and Personal Relationships, 22. 3. sz. 416-432.

World Health Organization (2005): WHO Study Group on Tobacco Product Regulation: report on the scientific basis of tobacco product regulations: fifth report of a WHO study group. World Health Organization, Geneva.

Widoni, C. és Ward, P. (2009): Effects of fair play instruction on student social skills during a middle school Sport Education unit. Physical Education and Sport Pedagogy, 14. 3. sz. $285-310$.

Wiersma, L. D. (2001): Conceptualization and development of the sources of enjoyment in youth sport questionnaire. Measurement in Physical Education and Exercise Science, $\mathbf{5}$. 3. sz. $153-177$.

Wiles, N., Haase, A., Lawlor, D., Ness, A. és Lewis, G. (2012): Physical activity and depression in adolescents: Cross-sectional findings from the ALSPAC cohort. Social Psychiatry and Psychiatric Epidemiology, 47. 7. sz. 1023-1033

Wilson, P. M. és Muon, S. (2008): Psychometric properties of the Exercise Identity Scale in a university sample. International Journal of Sport and Exercise Psychology, 6. 2. sz. 115-131. 
Wilson, P. M., Rodgers, W. M., Carpenter, P. J., Hall, C., Hardy, J. és Fraser, S. N. (2004): The relationship between commitment and exercise behavior. Psychology of Sport and Exercise, 5. 4. sz. 405-421.

Wong, H., Mak, C., és To, W. (2015): Development of a dental anxiety provoking scale: A pilot study in Hong. Kong. Journal of Dental Sciences, 10. 3.sz. 240-247.

Wood, R. (2018): The influence of teacher-student relationships and feedback on students' engagement with learning. Newcastle upon Tyne, Cambridge Scholars Publishing, United Kingdom.

Zahariditis, P., Tsorbatzoudis, C. és Grouios, G. (2002): Testing the Sport Commitment Model in the context of exercise and fitness particiation. Journal of Sport Behavior. 25. 3. sz. $217-231$. 


\section{ÁBRÁK JEGYZÉKE}

1. ábra. Egészséget befolyásoló tényezők (forrás: Hídvégi és Bíró,2015, 78. o.) ........................8

2. ábra. Dahlgren és Whitehead réteges modellje (forrás: Dahlgren és Whitehead, 1991 alapján, Orosz, 2001, 258. o.)

3. ábra. Az öndetermináció elmélet folyamatmodellje (forrás: saját szerkesztés, Deci és Ryan, 2000 alapján)

4. ábra. Az első sport-elköteleződés modell (forrás: saját szerkesztés; Scanlan és mtsai, 1993a)

5. ábra. Az új sport-elkötelezödés modell (forrás: saját szerkesztés; Scanlan és mtsai, 2016 alapján) .25

6. ábra. Sportélvezeti modell (forrás: saját szerkesztés; Wiersma, 2001 alapján). .32

7. ábra. A perfekcionizmus háromoldalú modellje (forrás: Stoeber és Otto, 2006, 296.o.)......36

8. ábra. A perfekcionizmus 2 x 2-es modellje (forrás: saját szerkesztés Guandreau és Thompson, 2010 alapján.) .36

9. ábra. Az öndeterminációs elmélet és az egészségmagtartás változása. .38

10. ábra. Elköteleződés típusok faktor szerkezete és faktorsúlya a CFA elemzés szerint .........55

11. ábra. Elköteleződés források faktor szerkezete és faktorsúlya a CFA elemzés szerint ........56

12. ábra. A sportolói identitás skála egy dimenziós faktorszerkezete és faktorsúlyai.. .66

13. ábra. A sport-elköteleződés Modell az öndeterminációs kontinuumon, a standardizáld regressziós együtthatókkal. .86

14. ábra. A sport elköteleződés modell kapcsolatai és kapcsolata az egészségattitüdökkel és jövőorientációval 100

15. ábra. A három sport-elköteleződés profil a z-score alapján 107 


\section{TÁBLÁZATOK JEGYZÉKE}

1. táblázat. Sport-elköteleződés modell fogalmi háttere........................................................26

2. táblázat. A kutatásban használt mérőeszközök cronbach alpha értékei. ................................49

3. táblázat. A sport-elköteleződés kérdőív megbízhatósági mutatói és korrelációja ...................58

4. táblázat. A sportélvezet skála feltáró faktoranalízis faktorsúlyai ..........................................62

5. táblázat. A sportélvezet skála fittségi mutatóit két modell esetében ........................................63

6. táblázat. A sportélvezet kérdőív megbízhatósági mutatói .....................................................64

7. táblázat. Sportolói identitás skála megbízhatósága a teljes mintán és almintákon.................66

8. táblázat. Sportolói identitás skála megbízhatósága a teljes mintán és almintákon .................67

9. táblázat. A sport-elköteleződés típusát befolyásoló független változók „stepwise” regresszióanalízis eredményének kivonata.................................................................69

10. táblázat. A sport-elköteleződés forrásait befolyásoló független változók „stepwise” regresszióanalízis eredményének kivonata I. .............................................................71

11. táblázat. A sport-elköteleződés forrásait befolyásoló független változók „stepwise” regresszióanalízis eredményének kivonata II. ...........................................................73

12. táblázat. A sport elköteleződés típusainak összehasonlítása sportolási jellemzők tükrében

13. táblázat. A sport elköteleződés egyéni szintü forrásainak összehasonlitása sportolási jellemzők tükrében

14. táblázat. A sport elkötelezödés közösségi szintü forrásainak összehasonlítása sportolási

jellemzők tükrében . .80

15. táblázat. Sportoló identitás különbségei szociodemográfiai és sport változók mentén ........91

16. táblázat. Korrelációs kapcsolatok a sportolói identitás az életkor és sport változók között 92

17. táblázat. Sportolói identitást és sport iránti elköteleződés regressziós kapcsolata ................94

18. táblázat. Átlag, szórás, z-érték és F értékek a klaszter csoportok számára ........................106

19. táblázat. Az elköteleződés profilok egészségpszichológiai különbségei...........................109

20. táblázat. A perfekcionizmus alskáláinak leíró statisztikája a nem és sportolási jellemzők tükrében

21. táblázat. A sport iránti elköteleződés és a perfekcionizmus kapcsolatainak vizsgálata korreláció-elemzéssel 116 
22. táblázat. A sportolók klaszterei a perfekcionizmus alskálák pontszámai alapján

23. táblázat. A klaszter-besorolás összefüggése a nemmel és sportolási jellemzőkkel 118

24. táblázat. A klaszter-besorolás összefüggése a sport iránti elkötelezettség típusaival és forrásaival

25. táblázat. A sportélvezet magyarázó változói Wiersma modellje alapján

26. táblázat. A sportélvezet faktorváltozói és a pszichológiai skálák, valamint a nem közötti kapcsolatos korrelációelemzése.

27 táblázat. A sportélvezet kategóriái és a pszichológiai skálák, valamint a nem közötti kapcsolatos korrelációelemzése. 125

28. táblázat. Az empirikus kutatás hipotéziseinek összefoglalása. 128 


\section{MELLÉKLETEK JEGYZÉK}

1. számú melléklet: Az első vizsgálat kérdőív csomagja.

Kedves Kitöltö!

Köszönjük, hogy részt veszel a sport elköteleződését vizsgáló kutatásunkban. A kitöltés anonim és önkéntes. A válaszaidat bizalmasan kezeljük, az eredményeket statisztikailag dolgozzuk fel. Fontos, hogy őszintén válaszolj a következő kérdésekre, melyekben nincsenek rossz válaszok!

\section{KÉRDÖÍV: SZOCIODEMOGRÁFIAI KÉRDÉSEK}

Kérlek, karikázd be, írd be vagy húzd alá, ami jellemző rád:

Nemed: $\quad 1 \ldots$ Férfi $\quad 2 \ldots$ Nő

Korod:

Milyen típusú iskolába jársz?

1. Általános iskola

2. Gimnázium

3. Szakgimnázium

4. Szakközépiskola

Hányadik osztályba?

Sporttagozatos iskolába jársz?

$1 \ldots$ Igen

$2 \ldots$ Nem

Az iskolában általában milyen jegyeket kapsz? (Csak egy választ jelölj be!)

1. 1-est, 2-est

2. 2-est, 3-ast

3. 3-ast

4. 3-ast, 4-est

5. 4-est

6. 4-est, 5-öst

7. 5-öst

Kivel élsz együtt?

1. Mindkét szülővel

Hány testvéred van?

2. Egyik szülővel és nevelőszülővel

3. Csak édesanyával

4. Csak édesapával

5. Egyéb, éspedig:

Lakásotok típusa:

1. Lakótelepi öröklakás

2. Társasházi öröklakás

3. Bérlakás

4. Családi ház

5. Egyéb:

Apukád legmagasabb iskolai végzettsége:
1. Általános iskola
2. Szakmunkásképző
3. Érettségi
4. Főiskola/egyetem

Apukád alkalmazási minősége:

1. Diplomás vagy vezető

2. Egyéb (nem diplomás) szellemi

3. Önálló vállalkozó

4. Szakmunkás

5. Segédmunkás

6. Munkanélküli

7. Nyugdíjas
Hol van az állandó lakhelyed?

1. Főváros

2. Megyeszékhely

3. Nagyváros

4. Kisváros

5. Község, falu

6. Tanya

Anyukád legmagasabb iskolai végzettsége:
1. Általános iskola
2. Szakmunkásképző
3. Érettségi
4. Főiskola/egyetem

Anyukád alkalmazási minősége:

1. Diplomás vagy vezető

2. Egyéb (nem diplomás) szellemi

3. Önálló vállalkozó

4. Szakmunkás

5. Segédmunkás

6. Munkanélküli

7. Nyugdíjas

8. Háztartásbeli

Családodat anyagi szempontból melyik társadalmi rétegbe sorolnád? 
1. Felsőosztály

2. Felső középosztály

3. Középosztály

4. Alsó középosztály

5. Alsó osztály

\section{KÉRDÖÍV: SPORTOLÓI SZOKÁSOK KÉRDÖÍV} rád:

A következőkben a sportolási szokásidra vagyunk kíváncsiak. Kérlek írd be, karikázd be vagy húzd alá, mi jellemző

Mit sportolsz? (Kérlek csak egy sportágat jelölj.)

Mióta sportolsz?

Milyen szervezésben sportolsz?

1. Iskolai (ebbe nem tartoznak bele az órarendben kötelező testnevelési órák)

2. Iskolán kívüli sportklub, sportszövetség stb.

3. Barátokkal, minden hivatalos háttér nélkül

4. Egyedül, a saját magam kedvéért

Milyen szinten sportolsz?

1. Válogatott szinten sportolok

2. Nemzetközi versenyeken indulok

3. Országos bajnokságokon, kupákon indulok

4. Megyei bajnokságokon indulok

5. Helyi, városi versenyeken indulok

6. Soha nem versenyeztem, de a jövöben valószínüleg versenyezni fogok

7. Soha nem versenyeztem, és a jövőben sem fogok

8. Hobbiszerüen sportolok

Hányszor sportolsz egy héten?

1. Heti 1

2. Heti 2-3

3. Heti $4-5$

4. Heti több

Fontosnak tartod-e az iskolai testnevelés órákat?

1. Szerintem fontosabb, mint az iskolai képzés más területei

2. Szerintem egyenértékủ az iskolai képzés más területeivel

3. Szerintem kevésbé fontos, mint az iskolai képzés más területei

4. Szerintem az iskolai képzés különböző területeit nem lehet összevetni

\section{KÉRDÖÍV: SPORT ELKÖTELEZÖDÉSI KÉRDÖÍV}

Kérlek, olvasd el az alábbi kérdéseket és értékeld, azokat, hogy mennyire jellemzőek rád sportolás közben. Gondolj a saját sportágadra! Mindegyik kérdésnél csak egyet válassz: 1=Egyáltalán nem jellemző rám - 5= Erősen jellemző rám.
1. Ez a sport szórakoztató.

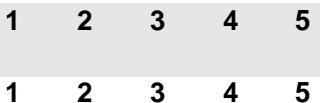
2. Sok időt töltök ezzel a sporttal.

$\begin{array}{lllll}1 & 2 & 3 & 4 & 5 \\ 1 & 2 & 3 & 4 & 5 \\ 1 & 2 & 3 & 4 & 5 \\ 1 & 2 & 3 & 4 & 5 \\ 1 & 2 & 3 & 4 & 5 \\ 1 & 2 & 3 & 4 & 5 \\ 1 & 2 & 3 & 4 & 5 \\ 1 & 2 & 3 & 4 & 5\end{array}$
9. Egyéb dolgok az életemben gátolják, hogy sportoljak.
$\begin{array}{lllll}1 & 2 & 3 & 4 & 5\end{array}$ 
10. A fizikai erőfeszítés, amit ebbe a sportba fektettem, megnehezíti, hogy abbahagyjam. $\quad \begin{array}{llllll}1 & 2 & 3 & 4 & 5\end{array}$

11. Szeretem ezt a sportot űzni.

$\begin{array}{lllll}1 & 2 & 3 & 4 & 5\end{array}$

12. Elkötelezett vagyok a sportágammal szemben.

$\begin{array}{lllll}1 & 2 & 3 & 4 & 5\end{array}$

13. Ha egyszer elérem a célom, új kihívásokat keresek, hogy fejlődhessek a sportágamban.

14. Nagyon hiányozna az utazás élménye, ha abbahagynám ezt a sportot.

$\begin{array}{lllll}1 & 2 & 3 & 4 & 5\end{array}$

15. A számomra fontos személyeknek nem tetszene, ha abbahagynám ezt a sportot, mert sokat fektettek belém.

16. A sportágamban a tökéletes teljesítményre törekszem.

17. Sok időt töltök edzéssel ebben a sportban. $\begin{array}{lllll}1 & 2 & 3 & 4 & 5\end{array}$

18. A számomra fontos személyek csalódottak lennének, ha abbahagynám ezt a sportot.

19. Van mentorom, aki segíti a sportpályafutásomat.

20. A számomra fontos személyek a legtöbb sportági versenyemen részt vesznek.

21. Úgy érzem, csapdába ejtett ez a sportág.

22. A számomra fontos személyek mellettem állnak akkor is, ha gyengén teljesítek a sportágamban.

23. Az idő, amit ebbe a sportba fektettem, megnehezíti, hogy abbahagyjam.

24. Mindig próbálok tanulni a saját hibáimból, amit e sportág üzése közben vétek.

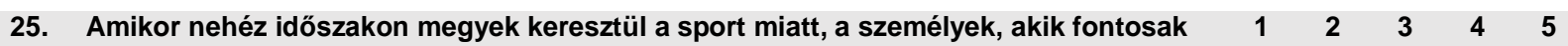
nekem, segítenek túljutni rajta.

26. Majdnem lehetetlen a sportágamat űzni egyéb dolgok miatt.

27. A számomra fontos személyek megtanítanak a sportágam stratégiáira.

28. Imádom ezt a sportot űzni.

29. Igyekszem mindig jobb lenni az ellenfélnél ebben a sportban.

30. Nagyon hiányoznának azok a dolgok, amiket sport közben tanulok, ha abbahagynám.

31. Hajlandó vagyok leküzdeni minden akadályt, hogy folytathassam ezt a sportot.

32. Habár gondolok rá, hogy abbahagyom ezt a sportot, mégis úgy érzem, folytatnom kell.

33. Minden alkalommal győzelemre törekszem, amikor versenyzek.

34. Nagyon sok mentális erőfeszítést fektettem a sportágamba.

35. A számomra fontos személyek megismertetnek ennek a sportnak a pszichikai oldalával.

36. Vannak olyan dolgok az életemben, amelyek korlátozzák a részvételemet ebben a sportban.

37. Feltehetően azért sem hagyom abba ezt a sportot, mert a számomra fontos személyek szintén ezt a sportágat üzik.

38. A sportágam minden részletében igyekszem fejlődni.

39. Úgy érzem, hogy kényszer miatt folytatom ezt a sportot.

$\begin{array}{lllll}1 & 2 & 3 & 4 & 5 \\ 1 & 2 & 3 & 4 & 5 \\ 1 & 2 & 3 & 4 & 5 \\ 1 & 2 & 3 & 4 & 5 \\ 1 & 2 & 3 & 4 & 5 \\ 1 & 2 & 3 & 4 & 5 \\ 1 & 2 & 3 & 4 & 5\end{array}$




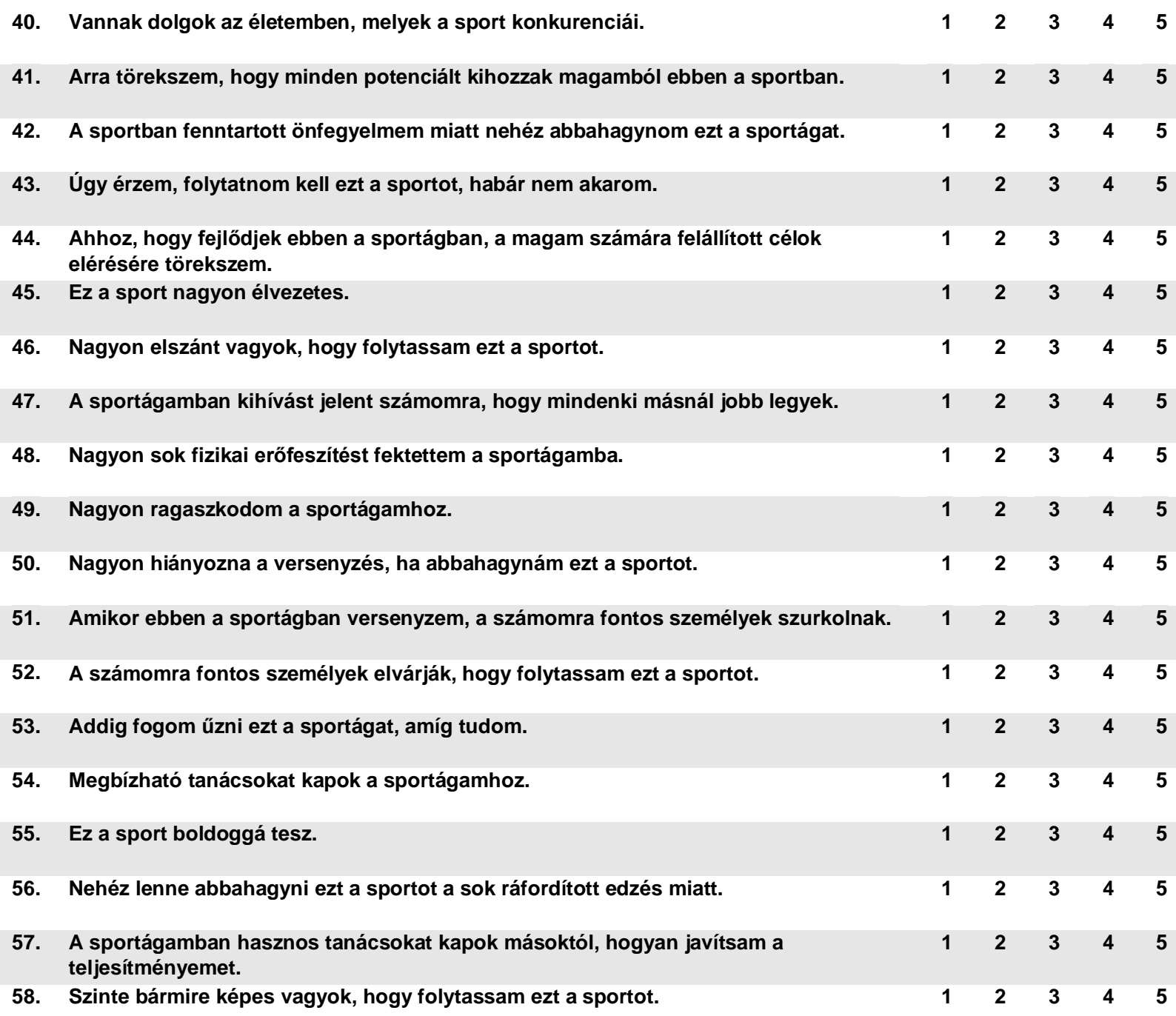

\section{KÉRDÖÍV: SPORT ÉLVEZET KÉRDÖÍV}

Kérlek, olvasd el az alábbi kérdéseket és értékeld, melyek jellemzőek rád sportolás közben! Mindegyik kérdésnél csak egyet válassz: $1=$ =gyáltalán nem jellemző rám - $5=$ Erősen jellemző rám

\section{Amikor a legjobban élvezem a sportot, úgy érzem azért van mert...}
1. kihasználom a lehetőségeimet.
2. keményen dolgozom az edzéseken.

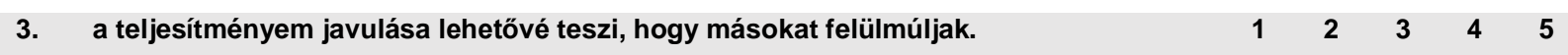

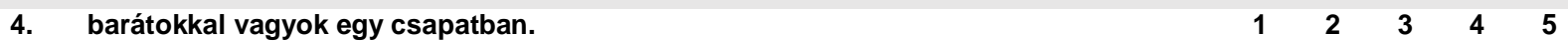

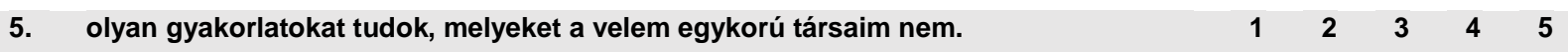

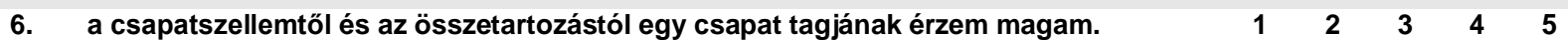
7. támogatást és bátorítást kapok a csapattársaktól. $\quad 1 \quad 2 \quad 3 \quad 4 \quad 5$

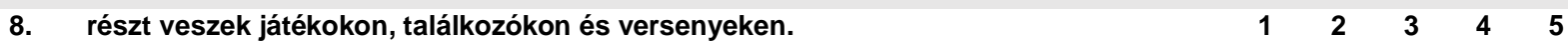



9. részt veszek kemény edzéseken és be tudom fejezni azokat.
$\begin{array}{lllll}1 & 2 & 3 & 4 & 5\end{array}$
10. új barátokat találok a sportágamban.
$\begin{array}{lllll}1 & 2 & 3 & 4 & 5\end{array}$
$\begin{array}{lllll}1 & 2 & 3 & 4 & 5\end{array}$
11. edzésen és versenyen kívül is találkozok a csapattársakkal.
12. mint sportoló sokan megismernek.
13. keményen játszom a versenyek alatt.

$\begin{array}{lllll}1 & 2 & 3 & 4 & 5\end{array}$
14. a teljesítményem javult a múlthoz képest.
$\begin{array}{lllll}1 & 2 & 3 & 4 & 5\end{array}$
15. hallom a tömeg éljenzését játék, meccs vagy verseny közben.
$\begin{array}{lllll}1 & 2 & 3 & 4 & 5\end{array}$
16. megmutathatom, hogy jobb vagyok a sportágamban, mint más.
17. bátorítást kapok a szüleimtöl.
18. jobb vagyok a kortársaimnál a saját sportágamban.

$\begin{array}{lllll}1 & 2 & 3 & 4 & 5\end{array}$
19. mások felismernek, mivel részt veszek ebben a sportban.
20. kimerültnek érzem magam versenyek és edzések után.

$\begin{array}{lllll}1 & 2 & 3 & 4 & 5\end{array}$
21. jobban játszom most, mint a múltban.
$\begin{array}{lllll}1 & 2 & 3 & 4 & 5\end{array}$
$\begin{array}{lllll}1 & 2 & 3 & 4 & 5\end{array}$
22. lelkesít a versenyzés.
23. támogatást kapok a szüleimtöl, ha a sportomat üzöm.
24. izgatottá tesz a versenyzés.
25. a szüleim megnéznek versenyzés közben.

$\begin{array}{lllll}1 & 2 & 3 & 4 & 5\end{array}$
26. nagy erőfeszítéseket teszek az edzéseken és versenyeken.
27. elérem a célom, melyet a saját teljesítményem alapján állítok fel.
28. a szüleim meg vannak elégedve a teljesítményemmel bármi történjen is.

$\begin{array}{lllll}1 & 2 & 3 & 4 & 5 \\ 1 & 2 & 3 & 4 & 5\end{array}$

\section{KÉRDÖÍV: JÖVŐORIENTÁLTSÁG}

Kérlek, olvasd el az alábbi kérdéseket és értékeld, melyek jellemzőek rád. Mindegyik kérdésnél csak egyet válassz: $1=$ Egyáltalán nem jellemző rám - 5= Teljes mértékben jellemző rám
1. Szoktam a jövőm alakulásán gondolkodni, és meg is próbálom tudatosan befolyásolni.
2. Gyakran olyan dolgokat is megteszek, amelynek eredményei csak évek múlva valósulnak meg.
3. Csak pillanatnyi érdekeimnek megfelelően cselekszem, az idő úgyis mindent elrendez magától.
4. Viselkedésem csak közvetlen (napokra-hetekre kiható) következmények határozzák meg. 
5. Hajlandó vagyok a pillanatnyi kényelmemet vagy boldogságomat feláldozni jövőbeli célok érdekében.

6. Azt hiszem, komolyan kell venni a figyelmeztető jeleket, még akkor is ha negatív következményekkel nem kell a közeljövőben számolni.

\section{KÉRDÖÍV: AZ ÉLETTEL VALÓ ELÉGEDETTSÉG SKÁLA}

Az alábbiakban öt állítást találsz, melyekkel kapcsolatban a véleményed kérdezzük. Arra kérünk, minden állítás esetében jelöld bekarikázással, hogy milyen mértékben értesz vele egyet. $1=$ Egyáltalán nem értek egyet - 7= Teljes mértékben egyetértek
1. Az életem a legtöbb tekintetben közel van az ideálishoz.

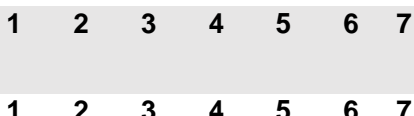
2. Az életkörülményeim kitűnőek.

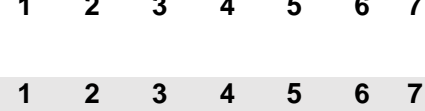
3. Elégedett vagyok az életemmel.
$\begin{array}{lllllll}1 & 2 & 3 & 4 & 5 & 6 & 7\end{array}$
4. Eddig minden fontosat megkaptam az életben, amit csak akartam.

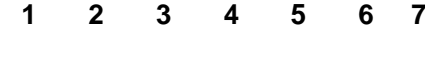
$\begin{array}{lllllll}1 & 2 & 3 & 4 & 5 & 6 & 7\end{array}$
5. Ha újra leélhetném az életem, szinte semmin sem változtatnék.

\section{KÉRDÖÍV: RÖVIDÍTETT ASPIRÁCIÓS INDEX}

Most lehetséges életcélokat fogunk felsorolni. Mennyire fontos számodra, hogy ezeket a célokat megvalósítsd a mindennapokban? Válaszolj a következők szerint:

\begin{tabular}{|c|c|c|c|c|c|}
\hline $\begin{array}{l}\text { Mennyire fontos számodra, hogy ezeket a } \\
\text { célokat megvalósítsd a mindennapokban? }\end{array}$ & $\begin{array}{l}\text { Egyáltalán } \\
\text { nem fontos }\end{array}$ & $\begin{array}{l}\text { Kevéssé } \\
\text { fontos }\end{array}$ & $\begin{array}{l}\text { Közepesen } \\
\text { fontos }\end{array}$ & $\begin{array}{l}\text { Meglehetösen } \\
\text { fontos }\end{array}$ & $\begin{array}{l}\text { Rendkívül } \\
\text { fontos }\end{array}$ \\
\hline \multicolumn{6}{|l|}{ 1. Pénzügyeim sikeresek legyenek. } \\
\hline \multicolumn{6}{|l|}{ 2. Fejlödjek, és új dolgokat tanuljak. } \\
\hline \multicolumn{6}{|l|}{ 3. Sok ember tiszteljen-csodáljon. } \\
\hline \multicolumn{6}{|l|}{$\begin{array}{l}\text { 4. Érezzem, hogy vannak emberek, akik } \\
\text { szeretnek, és viszontszeretem őket. }\end{array}$} \\
\hline \multicolumn{6}{|l|}{ 5. Mindig úgy nézzek ki, ahogyan elképzeltem. } \\
\hline \multicolumn{6}{|l|}{$\begin{array}{l}\text { 6. Munkámmal is hozzájáruljak, hogy a világ } \\
\text { jobb legyen. }\end{array}$} \\
\hline \multicolumn{6}{|l|}{ 7. Elkerüljenek a betegségek. } \\
\hline \multicolumn{6}{|l|}{ 8. Gazdag legyek. } \\
\hline \multicolumn{6}{|l|}{ 9. Ismerjem és elfogadjam valódi önmagam. } \\
\hline 10. Híres legyek. & & & & & \\
\hline
\end{tabular}




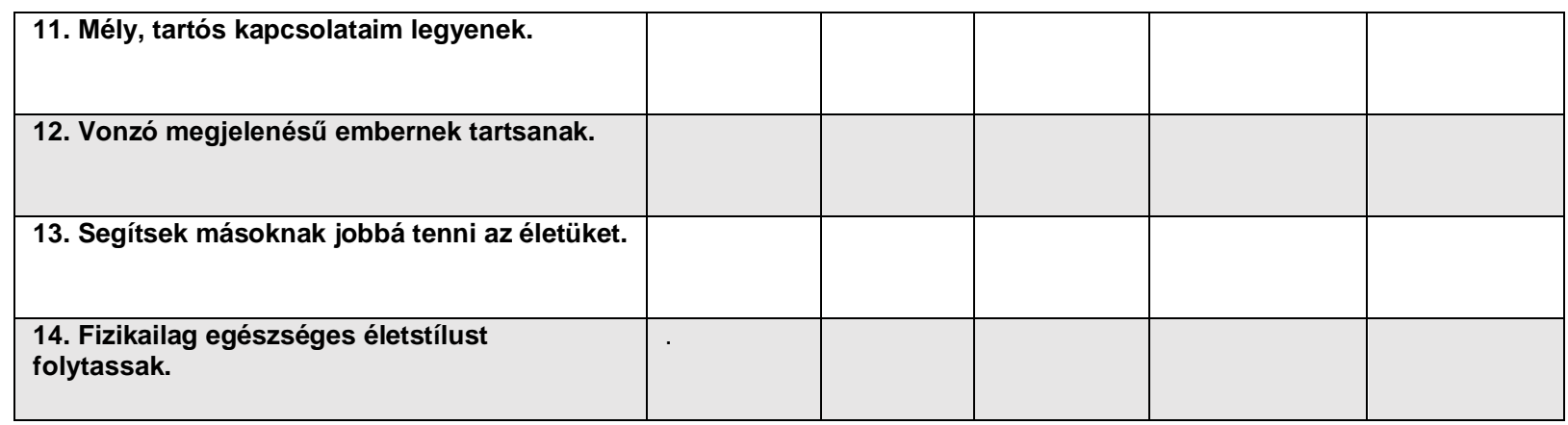

\section{KÉRDÖÍV: AZ EGÉSZSÉG ÉS A SPORT KAPCSOLATÁT VIZSGÁLÓ KÉRDÖÍV}

Kérlek, olvasd el az alábbi kérdéseket és értékeld, melyek jellemzőek rád. Mindegyik kérdésnél csak egyet válassz: 1=Egyáltalán nem jellemző rám - 5= Erősen jellemző rám.

1. Azért sportolok, hogy fogyjak.

2. Azért sportolok, hogy jól nézzek ki.

3. Azért sportolok, hogy izmos legyek.

4. Azért sportolok, hogy meglegyen a megfelelő fizikai állóképességem.

5. Azért sportolok, hogy ne legyek beteg.

6. Azért sportolok, hogy mentálisan erős legyek.

7. Azért sportolok, hogy levezessem a feszültséget.

8. Azért sportolok, hogy legyen önbecsülésem.

$\begin{array}{lllll}1 & 2 & 3 & 4 & 5 \\ 1 & 2 & 3 & 4 & 5 \\ 1 & 2 & 3 & 4 & 5 \\ 1 & 2 & 3 & 4 & 5 \\ 1 & 2 & 3 & 4 & 5 \\ 1 & 2 & 3 & 4 & 5 \\ 1 & 2 & 3 & 4 & 5 \\ 1 & 2 & 3 & 4 & 5\end{array}$

9. Milyenek tartod a saját egészségi állapotodat hasonló korúakkal összehasonlítva?
1. Rossz
2. Megfelelö
3. Jó
4. Kiváló

10. Saját bevallásod szerint, mennyit teszel az egészségedért? Szinte semmit

$$
\begin{array}{lllll}
1 & 2 & 3 & 4 & 5
\end{array}
$$
? Semennyire

2

3

4

5

6

7

Nagyon sokat

11. Saját bevallásod szerint, mennyire táplálkozol egészségesen?

$\begin{array}{lll}2 & 3 & 4\end{array}$


2. számú melléklet: A második vizsgálat kérdőív csomagja.

\section{Kedves Kitöltö!}

Köszönjük, hogy részt veszel a sport elköteleződést vizsgáló kutatásunkban. A kitöltés anonim és önkéntes. $A$ válaszaidat bizalmasan kezeljük, az eredményeket statisztikailag dolgozzuk fel. Fontos, hogy őszintén válaszolj a következő kérdésekre, melyekben nincsenek rossz válaszok!

\section{KÉRDŐÍV: SZOCIODEMOGRÁFIAI KÉRDÉSEK}

Kérlek, karikázd be, írd be vagy húzd alá, ami jellemző rád:

Nemed: Férfi

2 Nő

Korod:

Milyen típusú iskolába jársz?

1. Általános iskola

2. Gimnázium

3. Szakgimnázium

4. Szakközépiskola

Hányadik osztályba?

Sporttagozatos iskolába jársz?

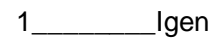

2 Nem

Az iskolában általában milyen jegyeket kapsz? (Csak egy választ jelölj be!)
1. 1-est, 2-est
2. 2-est, 3-ast
3. 3-ast
4. 3-ast, 4-est
5. 4-est
6. 4-est, 5-öst
7. 5-öst

Kivel élsz együtt?

1. Mindkét szülővel

2. Egyik szülővel és nevelőszülővel

3. Csak édesanyával

4. Csak édesapával

5. Egyéb, éspedig:

Lakásotok típusa:

1. Lakótelepi öröklakás

2. Társasházi öröklakás

3. Bérlakás

4. Családi ház

5. Egyéb:

Apukád legmagasabb iskolai végzettsége:

1. Általános iskola

2. Szakmunkásképző

3. Érettségi

4. Főiskola/egyetem

Apukád alkalmazási minősége:

1. Diplomás vagy vezető

2. Egyéb (nem diplomás) szellemi

3. Önálló vállalkozó

4. Szakmunkás

5. Segédmunkás

6. Munkanélküli

7. Nyugdíjas
Hány testvéred van?

Hol van az állandó lakhelyed?
1. Főváros
2. Megyeszékhely
3. Nagyváros
4. Kisváros
5. Község, falu
6. Tanya

Anyukád legmagasabb iskolai végzettsége:

1. Általános iskola

2. Szakmunkásképző

3. Érettségi

4. Főiskola/egyetem

Anyukád alkalmazási minősége:

1. Diplomás vagy vezető

2. Egyéb (nem diplomás) szellemi

3. Önálló vállalkozó

4. Szakmunkás

5. Segédmunkás

6. Munkanélküli

7. Nyugdíjas

8. Háztartásbeli

Családodat anyagi szempontból melyik társadalmi rétegbe sorolnád?

1. Felsőosztály

2. Felső középosztály 

3. Középosztály
4. Alsó középosztály
5. Alsóosztály

\section{KÉRDŐÍV: SPORTOLÓI SZOKÁSOK KÉRDŐÍV}

rád:

A következőkben a sportolási szokásidra vagyunk kíváncsiak. Kérlek írd be, karikázd be vagy húzd alá, mi jellemző

Mit sportolsz? (Kérlek csak egy sportágat jelölj.)

Hány éve sportolsz?

Mióta sportolsz versenyszerüen?

Heti hány órát töltesz el edzésessel?

Milyen szinten sportolsz?

1. Nemzetközi szint: válogatott kerettagként nemzetközi versenyeken veszek részt

2. Országos szint: országos versenyeken/bajnokságokon veszek részt

3. Helyi (pl. városi, megyei) versenyeken/bajnokságokon veszek részt

4. Nem versenyszerüen, hobbiszerüen sportolok

Volt-e sportsérülésed? Igen Nem

Ha igen, mennyi időt kellett kihagynod (leghosszabb kimaradás)?

Mennyire támogat közvetlen környezetted (család, barátok) a versenysportban?

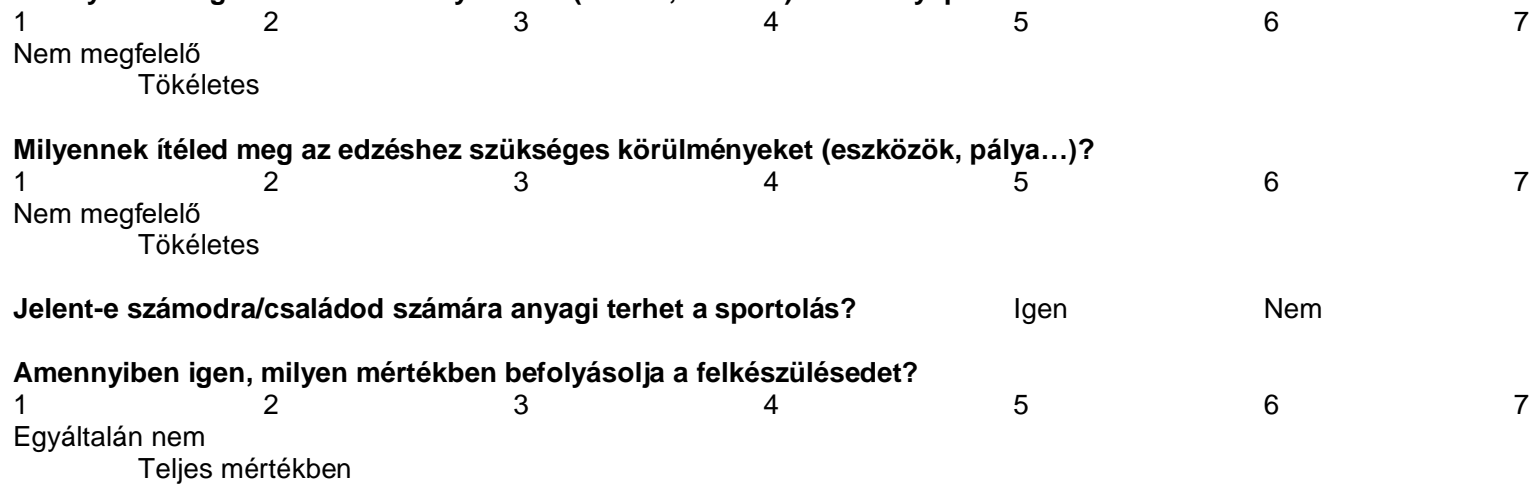

\section{KÉRDÖÍV: SPORT ELKÖTELEZŐDÉSI KÉRDŐÍV}

Kérlek, olvasd el az alábbi kérdéseket és értékeld azokat, hogy mennyire jellemzőek rád sportolás közben. Gondolj a saját sportágadra! Mindegyik kérdésnél csak egyet válassz: 1=Egyáltalán nem jellemző rám - 5= Erősen jellemző rám.

\begin{tabular}{|c|c|c|c|c|c|}
\hline 1. & Ez a sport szórakoztató. & 1 & 2 & 3 & 4 \\
\hline 2. & Sok idöt töltök ezzel a sporttal. & 1 & 2 & 3 & 4 \\
\hline 3. & Más dolgok az életemben megnehezítik a sportolást. & 1 & 2 & 3 & 4 \\
\hline 4. & Próbálok irányító szerepet betölteni ebben a sportban. & 1 & 2 & 3 & 4 \\
\hline 5. & Folyamatosan igyekszem fejleszteni magam ebben a sportban. & 1 & 2 & 3 & 4 \\
\hline 6. & $\begin{array}{l}\text { A mentális erőfeszítés, amit ebbe a sportba fektettek, megnehezíti, hogy } \\
\text { abbahagyjam. }\end{array}$ & 1 & 2 & 3 & 4 \\
\hline 7. & Inkább szükséglet, mint vágy, hogy folytassam ezt a sportot. & 1 & 2 & 3 & 4 \\
\hline 8. & $\begin{array}{l}\text { Vannak olyan jövőbeli versenyek/események, melyek hiányoznának, ha abbahagynám } \\
\text { ezt a sportot. }\end{array}$ & 1 & 2 & 3 & 4 \\
\hline 9. & Egyéb dolgok az életemben gátolják, hogy sportoljak. & 1 & 2 & 3 & 4 \\
\hline 10. & A fizikai eröfeszítés, amit ebbe a sportba fektettek, megnehezíti, hogy abbahagyjam. & 1 & 2 & 3 & 4 \\
\hline 11. & Szeretem ezt a sportot üzni. & 1 & 2 & 3 & 4 \\
\hline
\end{tabular}




\begin{tabular}{|c|c|c|c|c|c|c|}
\hline 12. & Elszánt vagyok, hogy sportoljak. & 1 & 2 & 3 & 4 & 5 \\
\hline 13. & Ha egyszer elérem a célom, új kihívásokat keresek, hogy fejlődhessek a sportban. & 1 & 2 & 3 & 4 & 5 \\
\hline 14. & Nagyon hiányozna az utazás élménye, ha abbahagynám ezt a sportot. & 1 & 2 & 3 & 4 & 5 \\
\hline 15. & $\begin{array}{l}\text { A számomra fontos személyeknek nem tetszene, ha abbahagynám ezt a sportot, mert } \\
\text { sokat fektettek belém. }\end{array}$ & 1 & 2 & 3 & 4 & 5 \\
\hline 16. & Tökéletes teljesítményre törekszem a sportban. & 1 & 2 & 3 & 4 & 5 \\
\hline 17. & Sok idöt töltök edzéssel ebben a sportban. & 1 & 2 & 3 & 4 & 5 \\
\hline 18. & A számomra fontos személyek csalódottak lennének, ha abbahagynám ezt a sportot. & 1 & 2 & 3 & 4 & 5 \\
\hline 19. & Van mentorom, aki segítséget nyújt a sportpályafutásomban. & 1 & 2 & 3 & 4 & 5 \\
\hline 20. & A számomra fontos személyek a föbb sport versenyeimen részt vesznek. & 1 & 2 & 3 & 4 & 5 \\
\hline 21. & Úgy érzem, csapdába ejtett ez a sport. & 1 & 2 & 3 & 4 & 5 \\
\hline 22. & $\begin{array}{l}\text { A számomra fontos személyek mellettem állnak akkor is, ha gyengén teljesítek a } \\
\text { sportban. }\end{array}$ & 1 & 2 & 3 & 4 & 5 \\
\hline 23. & Az idő, amit ebbe a sportba fektettem, megnehezíti, hogy abbahagyjam. & 1 & 2 & 3 & 4 & 5 \\
\hline 24. & Mindig próbálok tanulni a saját hibáimból, amit a sportolás közben vétek. & 1 & 2 & 3 & 4 & 5 \\
\hline 25. & $\begin{array}{l}\text { Amikor a sport miatt nehéz idöszakon megyek keresztül segítenek túljutni rajta azok a } \\
\text { személyek, akik fontosak nekem. }\end{array}$ & 1 & 2 & 3 & 4 & 5 \\
\hline 26. & Majdnem lehetetlen sportolni az életem egyéb dolgai miatt. & 1 & 2 & 3 & 4 & 5 \\
\hline 27. & A számomra fontos személyek megtanítanak a sportágam stratégiáira. & 1 & 2 & 3 & 4 & 5 \\
\hline 28. & Imádom ezt a sportot űzni. & 1 & 2 & 3 & 4 & 5 \\
\hline 29. & Igyekszem mindig jobbnak lenni az ellenfélnél ebben a sportban. & 1 & 2 & 3 & 4 & 5 \\
\hline 30. & $\begin{array}{l}\text { Ha abba hagynám a sportot nagyon hiányoznának azok a dolgok, amiket sport közben } \\
\text { tanulok. }\end{array}$ & 1 & 2 & 3 & 4 & 5 \\
\hline 31. & Hajlandó vagyok leküzdeni minden akadályt, hogy folytathassam ezt a sportot. & 1 & 2 & 3 & 4 & 5 \\
\hline 32. & Habár gondolok rá, hogy abbahagyom ezt a sportot, mégis úgy érzem, folytatnom kell. & 1 & 2 & 3 & 4 & 5 \\
\hline 33. & Minden alkalommal győzelemre törekszem, amikor versenyzek. & 1 & 2 & 3 & 4 & 5 \\
\hline 34. & Nagyon sok mentális erőfeszítést fektettem a sportágamba. & 1 & 2 & 3 & 4 & 5 \\
\hline 35. & $\begin{array}{l}\text { A számomra fontos személyek megismertetnek ennek a sportnak a pszichikai } \\
\text { oldalával. }\end{array}$ & 1 & 2 & 3 & 4 & 5 \\
\hline 36. & $\begin{array}{l}\text { Vannak olyan dolgok az életemben, amelyek korlátozzák a részvételemet ebben a } \\
\text { sportban. }\end{array}$ & 1 & 2 & 3 & 4 & 5 \\
\hline 37. & $\begin{array}{l}\text { Feltehetően azért sem hagyom abba ezt a sportot, mert a számomra fontos személyek } \\
\text { szintén ezt a sportot üzik. }\end{array}$ & 1 & 2 & 3 & 4 & 5 \\
\hline 38. & Ennek a sportnak minden részletében igyekszem fejlődni. & 1 & 2 & 3 & 4 & 5 \\
\hline 39. & Úgy érzem, hogy kényszerítve vagyok, hogy folytassam ezt a sportot. & 1 & 2 & 3 & 4 & 5 \\
\hline 40. & Vannak dolgok az életemben, melyek a sport konkurenciái. & 1 & 2 & 3 & 4 & 5 \\
\hline 41. & Arra törekszem, hogy minden lehetöséget kihozzak magamból ebben a sportban. & 1 & 2 & 3 & 4 & 5 \\
\hline 42. & A sportban fenntartott önfegyelmem miatt nehéz abbahagynom ezt a sportot. & 1 & 2 & 3 & 4 & 5 \\
\hline 43. & Úgy érzem, folytatnom kell ezt a sportot, habár nem akarom. & 1 & 2 & 3 & 4 & 5 \\
\hline 44. & $\begin{array}{l}\text { A sportban való fejlődésem érdekében a magam számára felállított célok elérésére } \\
\text { törekszem. }\end{array}$ & 1 & 2 & 3 & 4 & 5 \\
\hline 45. & Ez a sport nagyon élvezetes. & 1 & 2 & 3 & 4 & 5 \\
\hline 46. & Nagyon elszánt vagyok, hogy folytassam ezt a sportot. & 1 & 2 & 3 & 4 & 5 \\
\hline 47. & A sportban kihívást jelent számomra, hogy mindenki másnál jobb legyek. & 1 & 2 & 3 & 4 & 5 \\
\hline 48. & Nagyon sok fizikai erőfeszítést fektettem a sportba. & 1 & 2 & 3 & 4 & 5 \\
\hline 49. & Nagyon ragaszkodom a sporthoz. & 1 & 2 & 3 & 4 & 5 \\
\hline 50. & Nagyon hiányozna a versenyzés, ha abbahagynám ezt a sportot. & 1 & 2 & 3 & 4 & 5 \\
\hline
\end{tabular}




\begin{tabular}{|c|c|c|c|c|c|}
\hline 51. & Amikor ebben a sportban versenyzem, a számomra fontos személyek szurkolnak. & 1 & 2 & 3 & 4 \\
\hline 52. & A számomra fontos személyek elvárják, hogy folytassam ezt a sportot. & 1 & 2 & 3 & 4 \\
\hline 53. & Addig fogom űzni ezt a sportot, amíg tudom. & 1 & 2 & 3 & 4 \\
\hline 54. & Megbízható tanácsokat kapok a sporthoz. & 1 & 2 & 3 & 4 \\
\hline 55. & Ez a sport boldoggá tesz. & 1 & 2 & 3 & 4 \\
\hline 56. & Nehéz lenne abbahagyni ezt a sportot a sok ráfordított edzés miatt. & 1 & 2 & 3 & 4 \\
\hline 57. & $\begin{array}{l}\text { A sportágamban hasznos tanácsokat kapok másoktól, hogyan javítsam a } \\
\text { teljesítményemet. }\end{array}$ & 1 & 2 & 3 & 4 \\
\hline 58. & Szinte bármire képes vagyok, hogy folytassam ezt a sportot. & 1 & 2 & 3 & 4 \\
\hline
\end{tabular}

\section{SPORTOLÓI KIÉGÉS KÉRDÖÍV}

Ez a kérdőív 15 állítást tartalmaz, amelyek a sporttal kapcsolatos érzésekre vonatkoznak. Kérjük, olvasd el az egyes állításokat és jelöld meg válaszod az alábbiak szerint: 1=szinte soha - 5=szinte állandóan
1. Úgy érzem, érdemleges teljesítményt érek el a sportban.
$\begin{array}{lllll}1 & 2 & 3 & 4 & 5 \\ 1 & 2 & 3 & 4 & 5\end{array}$
2. Annyira fáradtnak érzem magam az edzéstől, hogy nehezen találok energiát más
3. Azt az erőfeszítést, amit a sportra szánok, talán jobb lenne más dolgokra fordítani.
$\begin{array}{lllll}1 & 2 & 3 & 4 & 5\end{array}$

$\begin{array}{lllll}1 & 2 & 3 & 4 & 5\end{array}$
4. Túlságosan fáradtnak érzem magam a sportolástól.
5. Úgy érzem, nem teljesítek túl jól a sportban.
$\begin{array}{lllll}1 & 2 & 3 & 4 & 5\end{array}$
6. Nem törődöm már annyira a sportteljesítményemmel, mint régebben.
$\begin{array}{lllll}1 & 2 & 3 & 4 & 5\end{array}$
7. Úgy érzem, nem teljesítek a képességeimnek megfelelően.

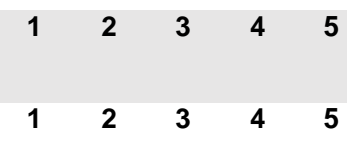
8. Holtfáradtnak érzem magam a sportolástól.

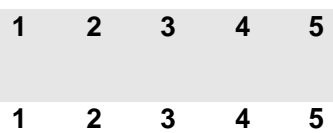
10. Úgy érzem, fizikailag ki vagyok merülve a sporttól.
$\begin{array}{lllll}1 & 2 & 3 & 4 & 5\end{array}$
11. Kevésbé tartom fontosnak, hogy sikeres legyek a sportban, mint régebben.

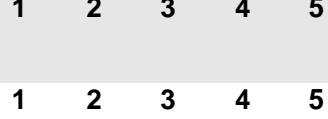
12. Kimerültem a sport mentális és fizikai követelményeitöl.
$\begin{array}{lllll}1 & 2 & 3 & 4 & 5\end{array}$
13. Úgy tünik, mindegy, mit csinálok, nem teljesítek annyira jól, mint kellene.
14. Sikeresnek érzem magam a sportban.
$\begin{array}{lllll}1 & 2 & 3 & 4 & 5\end{array}$
15. Negatív érzéseim vannak a sporttal kapcsolatban.
16. Úgy érzem, figyelemre méltó teljesítményt érek el a sportban.
$\begin{array}{lllll}1 & 2 & 3 & 4 & 5\end{array}$
17. Kevésbé aggódom, hogy sikeres legyek a sportban, mint régebben. 


\section{KÉRDÖÍV: SPORTOLÓI IDENTITÁS SKÁLA} egyetértek

Milyen mértékben értesz egyet a következő álításokkal? 1= Egyáltalán nem értek egyet - 7= Teljes mértékben

1. Sportolónak tartom magam.

2. Sok célom van a sporttal kapcsolatban

3. A legtöbb barátom sportoló.

4. A sport a legfontosabb része az életemnek.

5. Több időt töltök a sportra gondolva, mint bármi másra.

6. Szükségem van a sportra, hogy jól érezzem magam.

7. Mások leginkább sportolónak látnak engem.

8. Sport az egyetlen fontos dolog az életemben

9. Rosszul érzem magam amikor rosszul teljesítek a sportban.

10 Nagyon depressziós lennék, ha megsérülnék és nem tudnék versenyezni a sportágamban.

\section{KÉRDŐÍV: ÉRZÉKELT KÉPESSÉGEK SKÁLA} egyetértek

Milyen mértékben értesz egyet a következö állításokkal? 1= Egyáltalán nem értek egyet - 5= Teljes mértékben
1. Kitünő reflexeim vannak.
2. Ügyes vagyok és könnyed.
3. A testalkatom elég erös.
4. Gyorsan tudok futni.
5. Kontrolálom magam, amikor fizikai teszteket pl. ügyességi próbákat végzek.
6. Az izomzatom erős.
7. Büszke vagyok a képességeimre a sportban.
8. A gyorsaságom kisegít a szoros küzdelmekben.
9. Erős kézszorításom van.
10. A képességeim miatt képes vagyok olyan dolgokra, amikre más nem.

$\begin{array}{lllll}1 & 2 & 3 & 4 & 5 \\ 1 & 2 & 3 & 4 & 5 \\ 1 & 2 & 3 & 4 & 5 \\ 1 & 2 & 3 & 4 & 5 \\ 1 & 2 & 3 & 4 & 5 \\ 1 & 2 & 3 & 4 & 5 \\ 1 & 2 & 3 & 4 & 5 \\ 1 & 2 & 3 & 4 & 5 \\ 1 & 2 & 3 & 4 & 5 \\ 1 & 2 & 3 & 4 & 5\end{array}$

$\begin{array}{lllllll}1 & 2 & 3 & 4 & 5 & 6 & 7\end{array}$

$\begin{array}{lllllll}1 & 2 & 3 & 4 & 5 & 6 & 7\end{array}$

$\begin{array}{lllllll}1 & 2 & 3 & 4 & 5 & 6 & 7\end{array}$

$\begin{array}{lllllll}1 & 2 & 3 & 4 & 5 & 6 & 7\end{array}$

$\begin{array}{lllllll}1 & 2 & 3 & 4 & 5 & 6 & 7\end{array}$

$\begin{array}{lllllll}1 & 2 & 3 & 4 & 5 & 6 & 7\end{array}$

\section{KÉRDŐív: AZ ÉLETTEL VALÓ ELÉGEDETTSÉG SKÁLA}

Az alábbiakban öt állítást találsz, melyekkel kapcsolatban a véleményed kérdezzük. Arra kérünk, minden állítás esetében jelöld bekarikázással, hogy milyen mértékben értesz vele egyet. 1= Egyáltalán nem értek egyet - 7= Teljes mértékben egyetértek

\begin{tabular}{|c|c|c|c|c|c|c|c|c|}
\hline 1. & Az életem a legtöbb tekintetben közel van az ideálishoz. & 1 & 2 & 3 & 4 & 5 & 6 & 7 \\
\hline 2. & Az életkörülményeim kitűnőek. & 1 & 2 & 3 & 4 & 5 & 6 & 7 \\
\hline 3. & Elégedett vagyok az életemmel. & 1 & 2 & 3 & 4 & 5 & 6 & 7 \\
\hline 4. & $\begin{array}{l}\text { Eddig minden fontosat megkaptam az életben, amit csak } \\
\text { akartam. }\end{array}$ & 1 & 2 & 3 & 4 & 5 & 6 & 7 \\
\hline 5. & $\begin{array}{l}\text { Ha újra leélhetném az életem, szinte semmin sem } \\
\text { változtatnék. }\end{array}$ & 1 & 2 & 3 & 4 & 5 & 6 & 7 \\
\hline
\end{tabular}

\section{KÉRDÖÍV: MULTIDIMENZIONÁLIS PERFEKCIONIZMUS SKÁLA}

Mennyire jellemzőek rád az alábbi állítások? 1=Egyáltalán nem jellemző - 5= Nagyon jellemző

1. A szüleim nagyon magas mércét állítanak elém. 
2. A szervezettség nagyon fontos a számomra.

3. Gyerekként megbüntettek, ha a dolgokat nem tökéletesen csináltam meg.

4. Ha nem a legmagasabb mércét állítom fel magam elé, valószínüleg másodrendű emberként fogom végezni.

5. A szüleim sohasem próbálták megérteni a hibáimat.

6. Fontos számomra, hogy mindenhez alaposan értsek, amit csinálok.

7. Rendszerető ember vagyok.

8. Igyekszem összeszedett lenni.

9. Ha kudarcot vallok az iskolában, akkor emberként is kudarcot vallok.

10. Felzaklatna, ha hibát követnék el.

11. A szüleim azt akarták, hogy mindenben a legjobb legyek.

12. Magasabb célokat állítok magam elé, mint a legtöbb ember.

13. Ha valaki nálam jobban old meg egy feladatot az iskolában, úgy érzem, kudarcot vallottam benne.

14. Ha részben hibázok, az ugyanolyan rossz számomra, mintha komplett csődtömeg lennék.

15. Családomban csak a kiemelkedő teljesítmény tekinthető elég jónak.

16. Nagyon jó vagyok abban, hogy minden erőfeszítést megtegyek a célom érdekében.

17. Még ha elég figyelmesen is csinálok valamit, gyakran úgy érzem, hogy az nem elég jó.

18. Utálom, ha nem lehetek mindenben a legjobb.

19. Rendkívül magas céljaim vannak.

20. Szüleim elvárták, hogy kitűnő legyek.

21. Az emberek valószínüleg lenéznek majd, ha hibázok.

22. Soha nem éreztem azt, hogy meg tudok felelni a szüleim elvárásainak.

23. Ha nem teljesítek ugyanolyan jól, mint mások, ez azt jelenti, hogy alacsonyabb rendű vagyok náluk.

24. Úgy tünik, más emberek hozzám képest alacsonyabb színvonallal is beérik.

25. Ha nem csinálok mindig mindent jól, az emberek nem fognak tisztelni.

26. A szüleimnek mindig magasabb elvárásai voltak a jövőmmel kapcsolatban, mint nekem.

27. Megpróbálok összeszedett lenni.

28. Általában minden apróság miatt kételkedni szoktam.

29. A rend nagyon fontos a számomra.

30. Több mindent várok el magamtól a napi teendőimben, mint a legtöbb ember.

31. Összeszedett ember vagyok.

32. Hajlamos vagyok lemaradni a munkámmal, mivel újra és újra átnézem a dolgokat.

33. Sok idöt vesz igénybe, hogy a dolgokat úgy csináljam, ahogyan kell.

34. Minél kevesebb hibát ejtek, annál több ember fog kedvelni.

35. Soha nem érzem azt, hogy teljesíteni tudom a szüleim elöírásait.

$\begin{array}{lllll}1 & 2 & 3 & 4 & 5 \\ 1 & 2 & 3 & 4 & 5 \\ 1 & 2 & 3 & 4 & 5 \\ 1 & 2 & 3 & 4 & 5 \\ 1 & 2 & 3 & 4 & 5 \\ 1 & 2 & 3 & 4 & 5 \\ 1 & 2 & 3 & 4 & 5 \\ 1 & 2 & 3 & 4 & 5 \\ 1 & 2 & 3 & 4 & 5 \\ 1 & 2 & 3 & 4 & 5 \\ 1 & 2 & 3 & 4 & 5 \\ 1 & 2 & 3 & 4 & 5 \\ 1 & 2 & 3 & 4 & 5\end{array}$

$\begin{array}{lllll}1 & 2 & 3 & 4 & 5 \\ 1 & 2 & 3 & 4 & 5 \\ 1 & 2 & 3 & 4 & 5\end{array}$

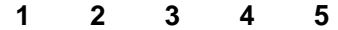

$\begin{array}{lllll}1 & 2 & 3 & 4 & 5 \\ 1 & 2 & 3 & 4 & 5\end{array}$

$\begin{array}{lllll}1 & 2 & 3 & 4 & 5\end{array}$

$\begin{array}{lllll}1 & 2 & 3 & 4 & 5\end{array}$

$\begin{array}{lllll}1 & 2 & 3 & 4 & 5\end{array}$

$\begin{array}{lllll}1 & 2 & 3 & 4 & 5\end{array}$

$\begin{array}{lllll}1 & 2 & 3 & 4 & 5\end{array}$

$\begin{array}{lllll}1 & 2 & 3 & 4 & 5 \\ 1 & 2 & 3 & 4 & 5 \\ 1 & 2 & 3 & 4 & 5 \\ 1 & 2 & 3 & 4 & 5 \\ 1 & 2 & 3 & 4 & 5 \\ 1 & 2 & 3 & 4 & 5 \\ 1 & 2 & 3 & 4 & 5 \\ 1 & 2 & 3 & 4 & 5 \\ 1 & 2 & 3 & 4 & 5 \\ 1 & 2 & 3 & 4 & 5 \\ 1 & 2 & 3 & 4 & 5 \\ 1 & 2 & 3 & 4 & 5\end{array}$

\section{KÉRDÖÍV: ROSENBERG ÖNÉRTÉKELÉS SKÁLA} $4=$ teljesen egyetértek

1. Úgy érzem, értékes ember vagyok legalább annyira, mint mások.

2. Úgy érzem, sok jó tulajdonságom van.

3. Mindent egybevetve hajlamos vagyok arra, hogy tehetségtelen, sikertelen embernek tartsam magam.

$\begin{array}{llll}1 & 2 & 3 & 4 \\ 1 & 2 & 3 & 4 \\ 1 & 2 & 3 & 4\end{array}$


4. Képes vagyok olyan jól csinálni a dolgokat, mint mások.

$\begin{array}{llll}1 & 2 & 3 & 4 \\ 1 & 2 & 3 & 4 \\ 1 & 2 & 3 & 4 \\ 1 & 2 & 3 & 4 \\ 1 & 2 & 3 & 4 \\ 1 & 2 & 3 & 4 \\ 1 & 2 & 3 & 4\end{array}$

10. Néha azt gondolom, hogy semmiben sem vagyok jó.

\section{KÉRDÖÍV: SPORTOLÓI MOTIVÁCIÓS SKÁLA}

Miért üződ a választott sportágad?

Kérjük gondolj arra, hogy miért üződ a számodra elsődlegesen választott sportágat. Az alábbi skála segítségével, kérjük jelöld meg, mennyire igazak az egyes állítások azzal kapcsolatban, hogy jelenleg miért is üződ ezt a sportágat vagy végzed ezt a sporttevékenységet.

\begin{tabular}{|c|c|c|c|c|c|c|c|c|}
\hline 1. & Mert rosszul érezném magam, ha nem fordítanék rá idöt. & 1 & 2 & 3 & & & 6 & 7 \\
\hline 2. & $\begin{array}{l}\text { Gyakran kérdezem én is magamtól, hogy miért csinálom még, mert már nem } \\
\text { látom, hogy elérném a céljaimat, amiket kitǔztem magam elé. }\end{array}$ & 1 & 2 & 3 & 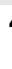 & 5 & 6 & 7 \\
\hline 3. & A nehéz mozgáskombinációk elvégzése közben érzett örömért. & 1 & 2 & 3 & & 5 & 6 & 7 \\
\hline 4. & Mert kifejezi a belső értékeimet. & 1 & 2 & 3 & & 5 & 6 & 7 \\
\hline 5. & Mert a számomra fontos embereket bosszantaná, ha nem csinálnám. & 1 & 2 & 3 & & 5 & 6 & 7 \\
\hline 6. & $\begin{array}{l}\text { Mert az egyik legjobb módja annak, hogy fejlesszem személyiségem más } \\
\text { oldalait is. }\end{array}$ & 1 & 2 & 3 & & 5 & 6 & 7 \\
\hline 7. & Mert örömöt okoz, hogy többet tanulok a sportágamról. & 1 & 2 & 3 & & 5 & 6 & 7 \\
\hline 8. & Mert a környezetemben lévő emberek megjutalmaznak érte. & 1 & 2 & 3 & & 5 & 6 & 7 \\
\hline 9. & Az eddig ismeretlen edzéstechnikák elsajátításakor érzett öröm miatt. & 1 & 2 & 3 & & 5 & 6 & 7 \\
\hline 10. & Olyan érzésem van, hogy már nem tudok sikeres lenni ebben a sportágban. & 1 & 2 & 3 & & 5 & 6 & 7 \\
\hline 11. & Mert nagyon érdekes megtanulnom, hogy miként fejlödhetek. & 1 & 2 & 3 & & 5 & 6 & 7 \\
\hline 12. & Mert ez a sport az önfejlesztésem egyik módja. & 1 & 2 & 3 & & 5 & 6 & 7 \\
\hline 13. & Mert azonos a belső értékrendemmel. & 1 & 2 & 3 & & 5 & 6 & 7 \\
\hline 14. & Mert élvezek új technikai elemeket megtanulni. & 1 & 2 & 3 & & 5 & 6 & 7 \\
\hline 15. & Mert mások nem helyeselnék, ha nem csinálnám. & 1 & 2 & 3 & & 5 & 6 & 7 \\
\hline 16. & Mert jobb érzésem van magammal kapcsolatban, amikor csinálom. & 1 & 2 & 3 & & 5 & 6 & 7 \\
\hline 17. & Már nem is egyértelmü számomra, hogy miért sportolok, nem hiszem, hogy & 1 & 2 & 3 & & 5 & 6 & 7 \\
\hline 18. & $\begin{array}{l}\text { Mert úgy gondolom ez egy jó módja a személyiségem értékes részeinek } \\
\text { fejlesztésére. }\end{array}$ & 1 & 2 & 3 & & 5 & 6 & 7 \\
\hline 19. & $\begin{array}{l}\text { Mert élvezem, ha új módszereket ismerhetek meg a teljesítményem } \\
\text { növelésére. }\end{array}$ & 1 & 2 & 3 & & 5 & 6 & 7 \\
\hline
\end{tabular}




\section{A JELÖLT DISSZERTÁCIÓHOZ KAPCSOLÓDÓ PUBLIKÁCIÓI}

Berki Tamás és Pikó Bettina (2017a): A sportélvezet pszichológiai hátterének vizsgálata serdülő sportolók körében. Magyar Sporttudományi Szemle, 18. 3. sz. 11-18.

Berki, T. és Pikó, B. (2017b): The source of Sport Enjoyment in young athletes in association with their future orientation and satisfaction with life. In: Ács, P., Bódog, F., Mechler, M., Mészáros, O. és Pónusz, R. (szerk.): Interdisciplinary Doctoral Conference 2017 Conference Book. Doctoral Student Association of the University of Pécs, Pécs, 124135.

Berki Tamás és Pikó Bettina (2017c): A sportélvezet forrásainak vizsgálata serdülő sportolók körében. Magyar Sporttudományi Szemle, 18. 2. sz. 30.

Berki Tamás és Pikó Bettina (2017d): Az egyéni és csapatsport jelentősége a serdülők sport iránti elköteleződésében. Magyar Sporttudományi Szemle, 18. 4. sz. 53.

Berki, T. és Pikó, B. (2017e): Hungarian adaptation and psychological correlates of Source of Enjoyment in Youth Sport Questionnaire among high school students. Cognition Brain Behaviour: An Interdisciplinary Journal, 21. 4. sz. 215-235.

Berki Tamás és Pikó Bettina (2018a): A sport elköteleződés forrásai a válogatott és a hobbi sportolók körében. Magyar Sporttudományi Szemle, 19. 5. sz. 55-56.

Berki Tamás és Pikó Bettina (2018b): A sport iránti elköteleződés összefüggése a sportolási szokásokkal és demográfiai tényezőkkel serdülő sportolók körében. In: Hamár Pál és Köpf Károly (szerk.): Mozgás - biológia - sport - tudomány, Magyar Edzők Társasága, Budapest, 170-180.

Berki Tamás és Pikó Bettina (2018c): A sport iránti elköteleződés összehasonlítása a sportolás egyes jellemzőinek tükrében serdülő sportolók körében. Magyar Sporttudományi Szemle, 19. 4. sz. 3-11.

Berki, T., és Pikó, B. (2018d): Psychological correlates between sport commitment profiles among adolescent athletes. In: Bunc, V., Tsolakidis, E. (szerk.): 23rd Annual Congress of the European College of Sport Science. Europen College of Sport Science, Dublin 571.

Berki Tamás és Pikó Bettina (2018e): Sport-elköteleződés típusok és pszichológiai skálák összefüggései serdülő sportolók körében. Magyar Sporttudományi Szemle, 19. 3. sz. 32. 
Berki, T. és Pikó, B. (2018f): The Role of Health Attitudes and Future Orientation in the Sport Commitment Model. In 9st European Conference on Positive Psychology 226-227.

Berki Tamás és Pikó Bettina (2019a): A magyar változatú Sportolói Identitás Skála faktorszerkezetének feltárása szociodemográfiai adatok mentén. In PÉK 2019 [CEA 2019] XVII. Pedagógiai Értékelési Konferencia, 21.

Berki Tamás és Pikó Bettina (2019b): A sport iránti elköteleződés és a perfekcionizmus összefüggései serdülő sportolók körében. Magyar Sporttudományi Szemle, 20. 2. sz. 3536.

Berki Tamás és Pikó Bettina (2019c): A sport-elköteleződés modell és az öndeterminációs elmélet kapcsolatai serdőlő sportolók körében. Magyar Sporttudományi Szemle, 20. 5. sz. 49.

Berki, T. és Pikó, B. (2019d): Understanding sport commitment among adolescent athletes: the role of a self-determination perspective. In: Bunc, V., Tsolakidis, E. (szerk.): 24th Annual Congress of the European College of Sport Science - Book of Abstracts. Europea College of Sport Science, Prague, 307-308.

Berki, T., Piko, B. F. és Page, R. M. (2019e): The relationship between the models of sport commitment and self-determination among adolescent athletes. Acta Facultatis Educationis Physicae Universitatis Comenianae, 59. 2. sz. 79-95.

Berki, T., Piko, B. F. és Page, R. M. (2020): Hungarian adaptation of the sport commitment questionnaire-2 and test of an expanded model with psychological variables, 86. 2 . sz. in press

Pikó Bettina és Berki Tamás (2019): Elkötelezettebbek-e a sportban a perfekcionisták? Serdülő sportolók vizsgálata. Magyar Sporttudományi Szemle, 20. 3. sz. 20-27. 